Nevada

Environmental

Restoration

Project

Corrective Action Decision Document/ Closure Report for Corrective Action Unit 367: Area 10 Sedan, Ess and Uncle Unit Craters Nevada National Security Site, Nevada

Controlled Copy No.:

Revision No.: 0

June 2011

Approved for public release; further dissemination unlimited.

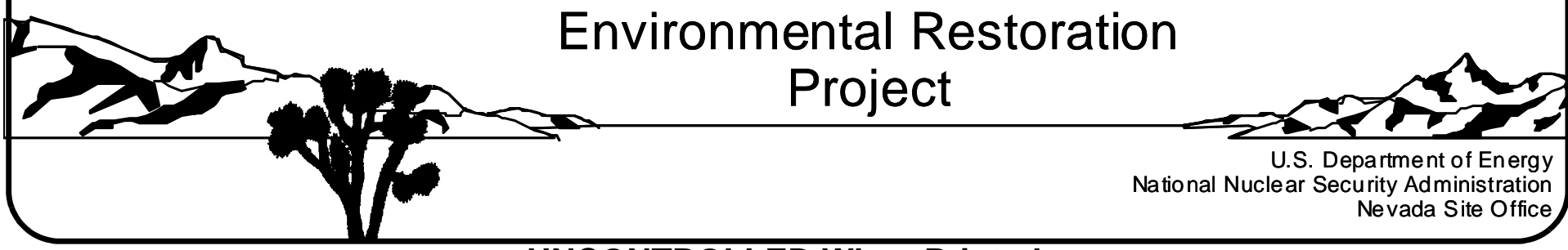


Available for sale to the public from:

U.S. Department of Commerce

National Technical Information Service

5301 Shawnee Road

Alexandria, VA 22312

Telephone: 800.553.6847

Fax: 703.605.6900

E-mail: orders@ntis.gov

Online Ordering: $\underline{h t t p: / / w w w . n t i s . g o v / h e l p / o r d e r m e t h o d s . a s p x ~}$

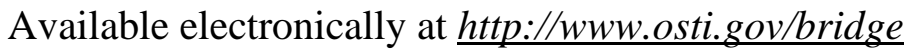

Available for a processing fee to U.S. Department of Energy and its contractors, in paper, from:

U.S. Department of Energy

Office of Scientific and Technical Information

P.O. Box 62

Oak Ridge, TN 37831-0062

Phone: 865.576.8401

Fax: 865.576.5728

Email: reports@adonis.osti.gov

Reference herein to any specific commercial product, process, or service by trade name, trademark, manufacturer, or otherwise, does not necessarily constitute or imply its endorsement, recommendation, or favoring by the United States Government or any agency thereof or its contractors or subcontractors. 


\title{
CORRECTIVE ACTION DECISION DOCUMENT/ CLOSURE REPORT FOR CORRECTIVE ACTION UNIT 367: AREA 10 SEDAN, ESS AND UNCLE UNIT CRATERS NEVADA NATIONAL SECURITY SITE, NEVADA
}

\author{
U.S. Department of Energy \\ National Nuclear Security Administration \\ Nevada Site Office \\ Las Vegas, Nevada
}

Controlled Copy No::

Revision No.: 0

June 2011

Approved for public release; further dissemination unlimited.

Reviewed and determined to be UNCLASSIFIED.

Derivative Classifier: Joseph P. Johnston/N-I CO

(Name/personalidentifier, and_position title)

Signature; /s/ Joseph P. Johnston

Date: 06/06/2011 


\section{CORRECTIVE ACTION DECISION DOCUMENT/CLOSURE REPORT FOR CORRECTIVE ACTION UNIT 367: \\ AREA 10 SEDAN, ESS AND UNCLE UNIT CRATERS \\ NEVADA NATIONAL SECURITY SITE, NEVADA}

Approved by: /s/ Kevin J. Cabble

Kevin J. Cabble

Federal Sub-Project Director

Soils Sub-Project

Approved by: /s/ Robert F. Boehlecke

Date: 06/09/2011

Robert F. Boehlecke

Federal Project Director

Environmental Restoration Project 


\section{Table of Contents}

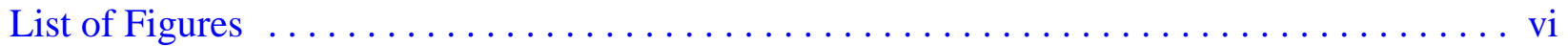

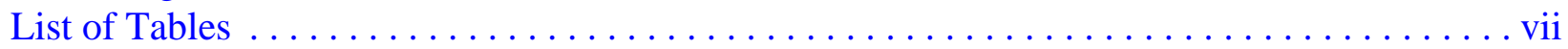

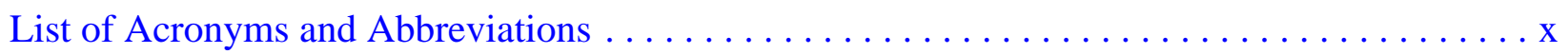

Executive Summary . . . . . . . . . . . . . . . . . . . . . . . . . . . . ES-1

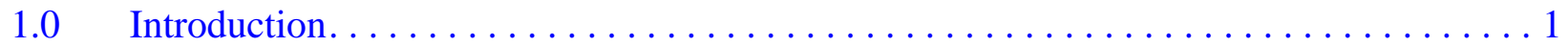

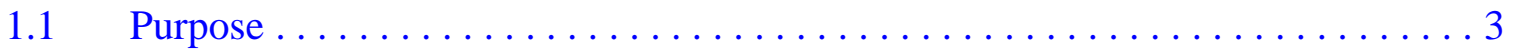

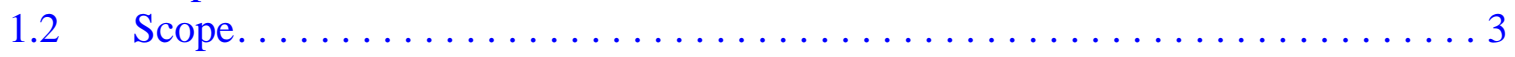

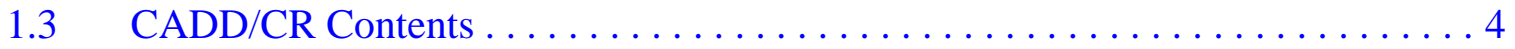

1.4 Applicable Programmatic Plans and Documents . . . . . . . . . . . . 5

2.0 Corrective Action Investigation Summary $\ldots \ldots \ldots \ldots \ldots \ldots \ldots \ldots \ldots \ldots \ldots$

2.1 Investigation Activities . . . . . . . . . . . . . . . . . . . . 7

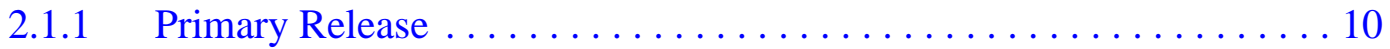

2.1 .2 Other Releases .............................. 11

2.1.2.1 Drainages ...................... 11

2.1.2.2 Mercury Highway/Circle Road . . . . . . . . . . . 12

2.1.2.3 CAS 10-09-03, Mud Pit . . . .............. 12

2.1.2.4 Potential Source Material .................. 13

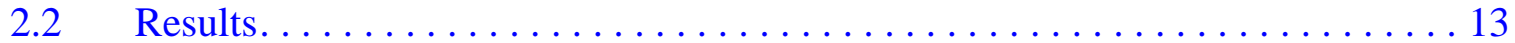

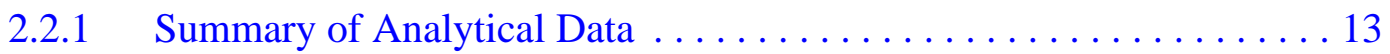

2.2.2 Data Assessment Summary . . . . . . . . . . . . . . . . 17

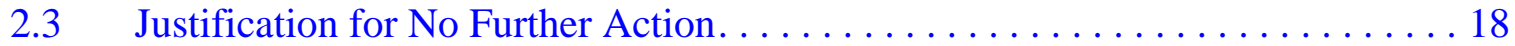

2.3.1 Final Action Levels. . . . . . . . . . . . . . . . . . . . . . . 18

2.3.2 Corrective Actions . . . . . . . . . . . . . . . . . . . . . 19

2.3.3 Best Management Practices . . . . . . . . . . . . . . . 20

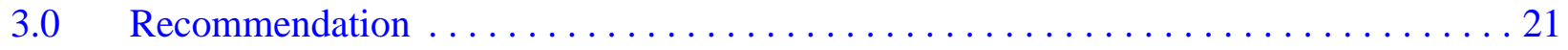

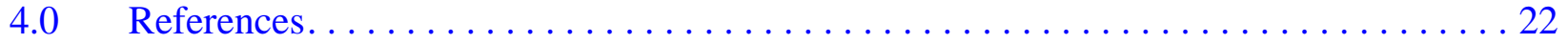

\section{Appendix A - Corrective Action Investigation Results}

A.1.0 Introduction. . . . . . . . . . . . . . . .

A.1.1 Project Objectives............................ A

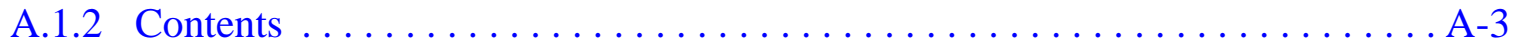

A.2.0 Investigation Overview $\ldots \ldots \ldots \ldots \ldots \ldots \ldots \ldots \ldots \ldots \ldots \ldots \ldots \ldots \ldots \ldots \ldots$

A.2.1 Sample Locations . . . . . . . . . . . . . . . . . . . . .

A.2.2 Investigation Activities . . . . . . . . . . . . . . . . . . . .

A.2.2.1 Visual Surveys . ........................ A-7

A.2.2.2 Radiological Surveys . . . . . . . . . . . . . . . . . . . A-7

A.2.2.3 Field Screening . . . . . . . . . . . . . . . . . A-9 


\section{Table of Contents (Continued)}

A.2.2.4 Soil Sampling ............................. A-10

A.2.2.5 Internal Dose Estimates $\ldots \ldots \ldots \ldots \ldots \ldots \ldots \ldots \ldots \ldots \ldots . \ldots \ldots . \ldots \ldots$

A.2.2.6 External Dose Measurements . . . . . . . . . . . . . . . A-13

A.2.3 Total Effective Dose . . . . . . . . . . . . . . . . . . . . . . . . . . . . . A-14

A.2.4 Laboratory Analytical Information. ........................ A-16

A.2.5 Comparison to Action Levels . . . . . . . . . . . . . . . . . . . . . . A-17

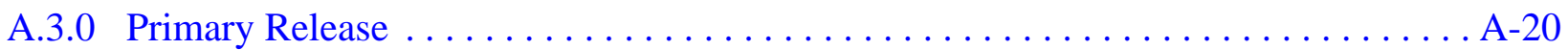

A.3.1 Corrective Action Investigation Activities . . . . . . . . . . . . . A-20

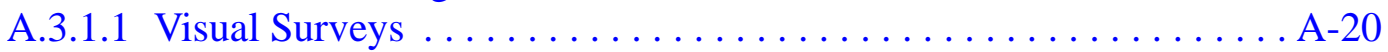

A.3.1.2 Radiological Surveys $\ldots \ldots \ldots \ldots \ldots \ldots \ldots \ldots \ldots \ldots \ldots$ A-26

A.3.1.2.1 Aerial Radiological Surveys ................ A-27

A.3.1.2.2 Ground-Based Radiological Surveys ........... A-27

A.3.1.2.3 Radiological Surveys Using the FIDLER ........ . . A-30

A.3.1.3 Sample Collection........................ A-32

A.3.1.3.1 Thermoluminescent Dosimeter Samples .......... A-32

A.3.1.3.2 Soil Samples ........................ A-34

A.3.1.4 Deviations ............................... A

A.3.2 Results......................................

A.3.2.1 Internal Dose Estimates ....................... A-35

A.3.2.1.1 Buried Contamination ................... A-35

A.3.2.1.2 Plutonium Ratios near the Uncle and Ess Craters . . . . . A-43

A.3.2.2 External Dose Estimates......................... A-44

A.3.2.3 Total Effective Dose .......................... A-47

A.3.3 Nature and Extent of Contamination . . . . . . . . . . . . . . . . A-51

A.3.4 Revised Conceptual Site Model ............................ A-56

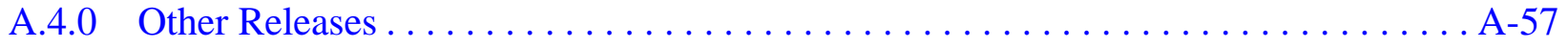

A.4.1 Drainages ................................... A-57

A.4.2 Mercury Highway/Circle Road. . . . . . . . . . . . . . . . . A-57

A.4.2.1 Corrective Action Investigation Activities.............. A-57

A.4.2.2 Results. ............................. A-59

A.4.2.3 Deviations ............................... A-59

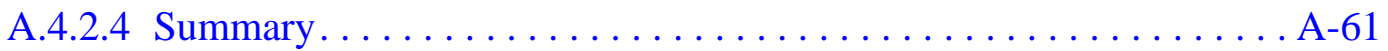

A.4.3 CAS 10-09-03, Mud Pit . ......................... A-61

A.4.3.1 Corrective Action Investigation Activities . . . . . . . . . . . . A-61

A.4.3.2 Results................................ A-64

A.4.3.3 Deviations .............................. A-64

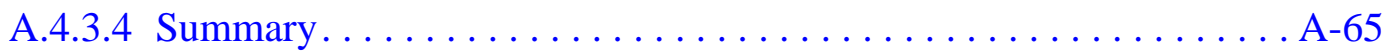

A.4.4 Potential Source Material ........................... A-65

A.4.4.1 Corrective Action Investigation Activities................ A-66 


\section{Table of Contents (Continued)}

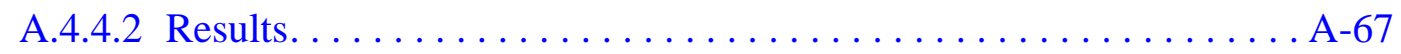

A.4.4.3 Deviations............................... A-70

A.4.4.4 Summary ......................... A-70

A.4.5 Nature and Extent of Contamination-Other Releases . . . . . . . . . . A-70

A.4.6 Revised Conceptual Site Model-Other Releases . . . . . . . . . . . . . . . A-71

A.5.0 Waste Management . . . . . . . . . . . . . . . . . . . . . . . A-72

A.5.1 Waste Generation . . . . . . . . . . . . . . . . . . . . . . A-72

A.5.2 Waste Characterization . . . . . . . . . . . . . . . . . . . . A-72

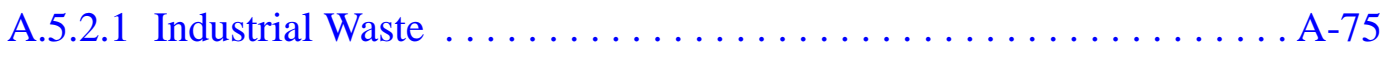

A.5.2.1.1 Sampling Equipment and PPE ............. A-75

A.5.2.1.2 Surface Debris . . . . . . . . . . . . . . . A-75

A.5.2.2 Mixed Low-Level Waste . . . . . . . . . . . . . . . . . . . A-75

A.5.2.3 Recyclable Materials. . . . . . . . . . . . . . . . . . . . . . A-76

A.5.2.4 Low-Level Waste . . . . . . . . . . . . . . . . . . . . A-76

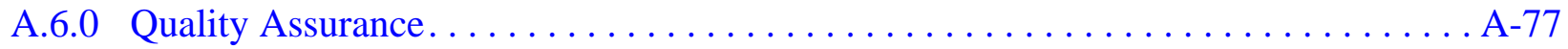

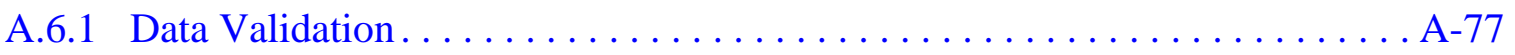

A.6.1.1 Tier I Evaluation . . . . . . . . . . . . . . . . . . . . . A-77

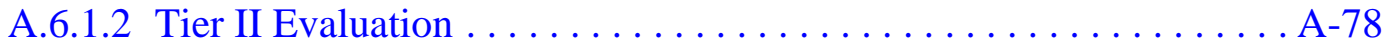

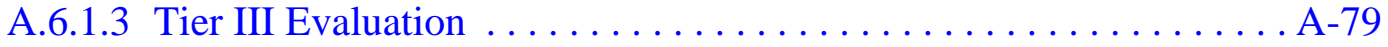

A.6.2 Field QC Samples . . . . . . . . . . . . . . . . . . . . A-80

A.6.2.1 Laboratory QC Samples ... . . . . . . . . . . . . . . . . . A-80

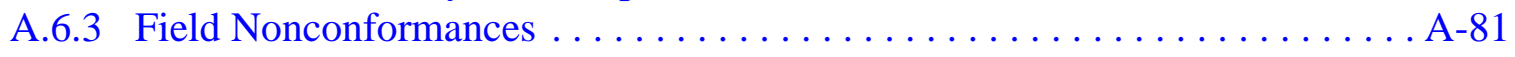

A.6.4 Laboratory Nonconformances . . . . . . . . . . . . . . . . A-81

A.6.5 Thermoluminescent Dosimeter Data Validation . . . . . . . . . . . . . A-81

A.7.0 Summary ................................ A-

A.8.0 References.................................. A-84

\section{Appendix B - Data Assessment}

B.1.0 Data Assessment. . . . . . . . . . . . . . . . . . . . . . . B-1

B.1.1 Review DQOs and Sampling Design . . . . . . . . . . . . . . B-2

B.1.1.1 Decision I . . . . . . . . . . . . . . . . . . . B-2

B.1.1.1.1 DQO Provisions to Limit

False Negative Decision Error . . . . . . . . . B-2

B.1.1.1.2 DQO Provisions to Limit

False Positive Decision Error . . . . . . . . . B-10

B.1.1.2 Decision II . . . . . . . . . . . . . . . . . . B-10

B.1.1.3 Sampling Design. ....................... B-11 


\section{Table of Contents (Continued)}

B.1.2 Conduct a Preliminary Data Review .................... B-11

B.1.3 Select the Test and Identify Key Assumptions . . . . . . . . . . . . . . . B-11

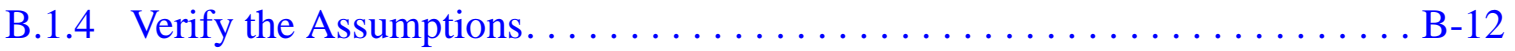

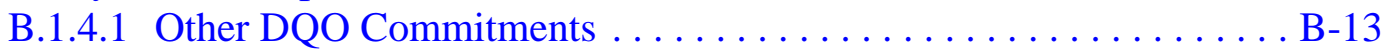

B.1.5 Draw Conclusions from the Data . . . . . . . . . . . . . . . . . .

B.1.5.1 Decision Rules for Decision I. . . . . . . . . . . . . . . . . . . . B-14

B.1.5.2 Decision Rules for Decision II . . . . . . . . . . . . . B-15

B.2.0 References................................... B-17

\section{Appendix C - Risk Assessment}

C.1.0 Risk Assessment . . . . . . . . . . . . . . . . . . . . . . .

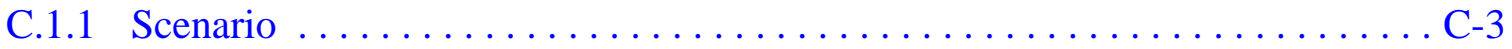

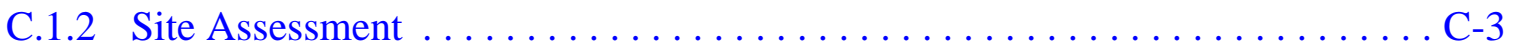

C.1.3 Site Classification and Initial Response Action . . . . . . . . . . . . . C-4

C.1.4 Development of Tier 1 Lookup Table of RBSLs . . . . . . . . . . . . . . C-4

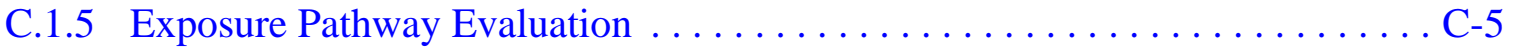

C.1.6 Comparison of Site Conditions with Tier 1 RBSLs . . . . . . . . . . . C-5

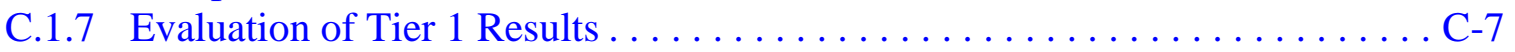

C.1.8 Tier 1 Remedial Action Evaluation $\ldots \ldots \ldots \ldots \ldots \ldots \ldots \ldots \ldots \ldots \ldots$ C-7

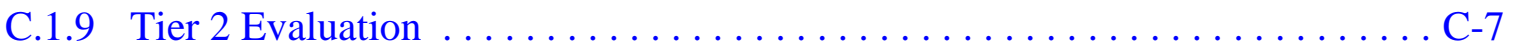

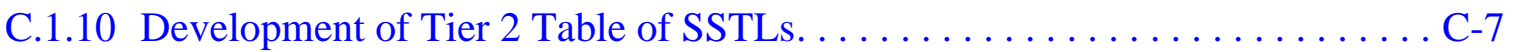

C.1.11 Comparison of Site Conditions with Tier 2 Table SSTLs . . . . . . . . . . . C-11

C.1.12 Tier 2 Remedial Action Evaluation .................... C-11

C.2.0 Recommendations............................. C-12

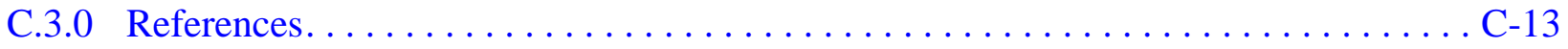

Attachment C-1 - Derivation of Residual Radioactive Material Guidelines

for Radionuclides in Soil at CAU 367 Area 10 Sedan, Ess and Uncle Unit Craters Nevada National Security Site, Nevada

\section{Appendix D - Closure Activity Summary (Use Restrictions)}

D.1.0 Closure Activity Summary $\ldots \ldots \ldots \ldots \ldots \ldots \ldots \ldots \ldots \ldots \ldots \ldots \ldots \ldots \ldots \ldots \ldots$

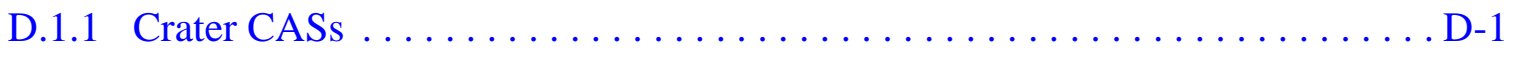

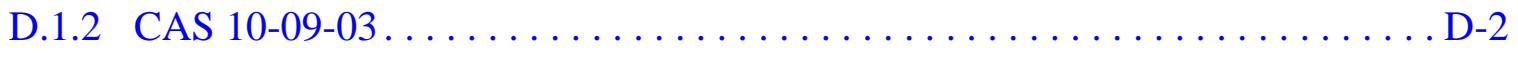

D.1.3 Potential Source Material Locations. . . . . . . . . . . . . . . D-2

D.2.0 References...................................... D-3 


\section{Table of Contents (Continued)}

\section{Attachment D-1 - Waste Disposition Documentation}

\section{Attachment D-2 - Use Restrictions}

\section{Appendix E - Evaluation of Corrective Action Alternatives}

E.1.0 Introduction. . . . . . . . . . . . . . .

E.1.1 Corrective Action Objectives . . . . . . . . . . . . . . . . . E-1

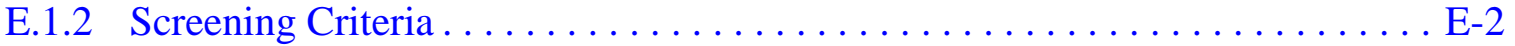

E.1.3 Corrective Action Standards. . . . . . . . . . . . . . . . . . . . E-3

E.1.3.1 Remedy Selection Decision Factors . . . . . . . . . . . . . . E-3

E.1.4 Development of Corrective Action Alternatives . . . . . . . . . . . . . . E-5

E.1.4.1 Alternative $1-$ No Further Action . . . . . . . . . . . . . . . . . E-5

E.1.4.2 Alternative 2 - Clean Closure. . . . . . . . . . . . . . . . . . E-5

E.1.4.3 Alternative 3 -Closure in Place . . . . . . . . . . . . . . . . . E-6

E.1.5 Evaluation and Comparison of Alternatives. . . . . . . . . . . . E-6

E.2.0 Recommended Alternative . . . . . . . . . . . . . . . . . . . . . E-11

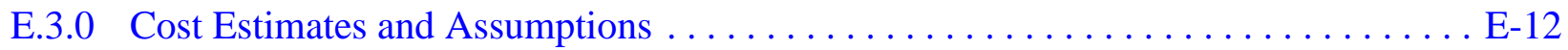

E.4.0 References. ................................. E-13

\section{Appendix F - Composite Sample Plot Analytical Data}

F.1.0 Primary Release Sample Data. . . . . . . . . . . . . . . . . . . F-1

F.1.1 Soil Analytical Data . . . . . . . . . . . . . . . . . . . . F-1

F.1.2 Thermoluminescent Dosimeter Element Data . . . . . . . . . . . . F-1

\section{Appendix G - Sample Location Coordinates}

G.1.0 Sample Location Coordinates. . . . . . . . . . . . . . . . . . . G-1

G.2.0 References..................................

Appendix H - Nevada Division of Environmental Protection Comments 


\section{List of Figures}

Number

Title

Page

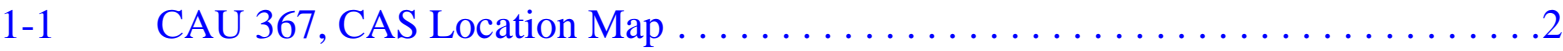

A.1-1 CAU 367, CAS Location Map ........................ A-2

A.2-1 CAU 367 Sample and TLD Locations .................... A-8

A.2-2 Field Background TLD Locations and Natural Background Isopleths . . . . . A A-15

A.3-1 Radiological Survey Results (Four Vectors) $\ldots \ldots \ldots \ldots \ldots \ldots \ldots \ldots$ A-28

A.3-2 Radiological Survey Results (South Vector) $\ldots \ldots \ldots \ldots \ldots \ldots \ldots \ldots$ A-29

A.3-3 Radiological Survey Results (Large Area Transects) ............... A-31

A.3-4 Internal Dose Results and Americium Aerial Survey Results . . . . . . . . . A-38

A.3-5 Screening Boring Locations and Sedan Ejecta Thickness Contours . . . . . . . A-41

A.3-6 Total Effective Dose (95 Percent UCL) for Remote Work Area Scenario

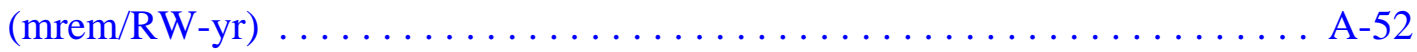

A.3-7 Total Effective Dose (95 Percent UCL) for Industrial Use Area Scenario

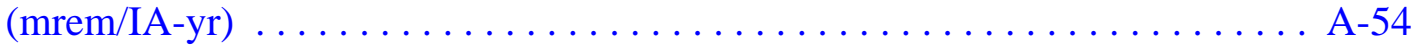

A.3-8 Administrative Use Restriction Boundary .................. A-55

A.4-1 Drainage Survey $\ldots \ldots \ldots \ldots \ldots \ldots \ldots \ldots \ldots \ldots \ldots \ldots \ldots \ldots$ A-58

A.4-2 Radiological Survey Results (Circle Road) ................... A-60

A.4-3 Other Release Sample Locations $\ldots \ldots \ldots \ldots \ldots \ldots \ldots \ldots \ldots \ldots \ldots$ A-63

C.1-1 Risk-Based Corrective Action Decision Process ...................... 


\section{List of Tables}

Number

Title

Page

2-1 Total Effective Dose at Primary Release Sample Locations (mrem/yr) . . . . . . 15

A.2-1 Laboratory Analyses and Methods, CAU 367 Investigation Samples . . . . . . . A-17

A.3-1 Soil Samples Collected at CAU $367 \ldots \ldots \ldots \ldots \ldots \ldots \ldots \ldots \ldots \ldots \ldots \ldots \ldots$

A.3-2 Thermoluminescent Dosimeters at CAU $367 \ldots \ldots \ldots \ldots \ldots \ldots \ldots \ldots$ A-24

A.3-3 Deviations from CAIP: Primary Release. ................ A-36

A.3-4 Internal Dose Estimates $\ldots \ldots \ldots \ldots \ldots \ldots \ldots \ldots \ldots \ldots \ldots \ldots \ldots \ldots \ldots \ldots \ldots \ldots$

A.3-5 Internal Dose Estimates (95 Percent UCL) at Sample Plots for

Each Exposure Scenario . . . . . . . . . . . . . . . . . . . . A-39

A.3-6 Field Screening Data for Screening Borings $\ldots \ldots \ldots \ldots \ldots \ldots \ldots \ldots$. . . . A-42

A.3-7 External Dose Estimates (95 Percent UCL) at TLD Locations for

Each Exposure Scenario . . . . . . . . . . . . . . . . . . . . A-44

A.3-8 Ratio of Internal Dose to External Dose at Sample Plots (mrem/IA-yr) . . . . A-48

A.3-9 Total Effective Dose at Primary Release Sample Locations (mrem/yr) . . . . . A-49

A.4-1 Deviations from CAIP: Other Releases . . . . . . . . . . . . . A-62

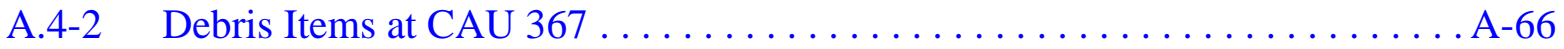

A.4-3 Sample Results above MDCs at PSM Sample Locations. . . . . . . . . . . . . A-68

A.5-1 Waste Summary $\ldots \ldots \ldots \ldots \ldots \ldots \ldots \ldots \ldots \ldots \ldots \ldots \ldots \ldots \ldots \ldots$

A.5-2 Waste Characterization Sample Results . . . . . . . . . . . . . A-74

B.1-1 Input Values and Minimum Number of Soil Samples Required for the Remote Work Area Exposure Scenario. . . . . . . . . . . . . . B-4 


\section{List of Tables (Continued)}

B.1-2 Input Values and Minimum Number of TLD Samples Required for the Remote Work Area Exposure Scenario ................... B-5

B.1-3 Precision Measurements $\ldots \ldots \ldots \ldots \ldots \ldots \ldots \ldots \ldots \ldots \ldots \ldots$ B-8

B.1-4 Key Assumptions.............................. B-12

C.1-1 Primary Release Locations Where TED Exceeds the Tier 1 RBSL . . . . . . . . C-6

C.1-2 Maximum Potential Dose for Potentially Exposed Workers at CAU 367. . . . C C-10

E.1-1 Evaluation of General Corrective Action Standards . . . . . . . . . . . . . E-7

E.1-2 Evaluation of Remedy Selection Decision Factors .................... E-8

E.3-1 Use Restriction Boundary Areas at CAU $367 \ldots \ldots \ldots \ldots \ldots \ldots \ldots$.

F.1-1 Gamma Spectroscopy Sample Results for Radionuclides

Detected above MDCs at Northeast Vector ....................F-2

F.1-2 Isotopic Sample Results for Radionuclides

Detected above MDCs at Northeast Vector .....................F-3

F.1-3 Gamma Spectroscopy Sample Results for Radionuclides

Detected above MDCs at East Vector . . . . . . . . . . . . . . . . . . . . F-4

F.1-4 Isotopic Sample Results for Radionuclides

Detected above MDCs at East Vector . . . . . . . . . . . . . . . . . . . F-5

F.1-5 Gamma Spectroscopy Sample Results for Radionuclides

Detected above MDCs at South Vector ........................F-6

F.1-6 Isotopic Sample Results for Radionuclides

Detected above MDCs at South Vector ........................F-8

F.1-7 Gamma Spectroscopy Sample Results for Radionuclides

Detected above MDCs at Northwest Vector . . . . . . . . . . . . . . F-10 


\section{List of Tables (Continued)}

Number

Title

Page

F.1-8 Isotopic Sample Results for Radionuclides

Detected above MDCs at Northwest Vector ......................F-11

F.1-9 Thermoluminescent Dosimeter Results for CAU 367 (mrem) ............F-12

F.1-10 Results for Background TLDs at CAU 367 (mrem) $\ldots \ldots \ldots \ldots \ldots \ldots$.

G.1-1 Sample Plot and TLD Location Coordinates

for the Primary Release at CAU $367 \ldots \ldots \ldots \ldots \ldots \ldots \ldots \ldots \ldots \ldots \ldots \ldots \ldots$

G.1-2 Sample Location Coordinates for Background TLDs at CAU $367 \ldots . . . \ldots$. G-3

G.1-3 Sample Location Coordinates for the Other Releases at CAU 367. ......... G-4 


\section{List of Acronyms and Abbreviations}

Ac

Am

ANPR

ASTM

bgs

BMP

CAA

CADD

CAI

CAIP

CAS

CAU

CFR

CLP

$\mathrm{cm}$

Co

COC

COPC

cps

$\mathrm{Cr}$

CR

Cs

CSM

day/yr

DOE

$\mathrm{dpm} / 100 \mathrm{~cm}^{2}$
Actinium

Americium

Advance Notice of Proposed Rulemaking

ASTM International

Below ground surface

Best management practice

Corrective action alternative

Corrective action decision document

Corrective action investigation

Corrective action investigation plan

Corrective action site

Corrective action unit

Code of Federal Regulations

Contract Laboratory Program

Centimeter

Cobalt

Contaminant of concern

Contaminant of potential concern

Counts per second

Chromium

Closure report

Cesium

Conceptual site model

Days per year

U.S. Department of Energy

Disintegrations per minute per 100 square centimeters 


\section{List of Acronyms and Abbreviations (Continued)}

\begin{tabular}{|c|c|}
\hline DQA & Data quality assessment \\
\hline DQI & Data quality indicator \\
\hline DQO & Data quality objective \\
\hline EML & Environmental Measurements Laboratory \\
\hline EPA & U.S. Environmental Protection Agency \\
\hline $\mathrm{Eu}$ & Europium \\
\hline FAL & Final action level \\
\hline FD & Field duplicate \\
\hline FFACO & Federal Facility Agreement and Consent Order \\
\hline FIDLER & Field instrument for the detection of low-energy radiation \\
\hline FSL & Field screening limit \\
\hline $\mathrm{ft}$ & Foot \\
\hline GPS & Global Positioning System \\
\hline HASL & Health and Safety Laboratory \\
\hline hr/day & Hours per day \\
\hline $\mathrm{hr} / \mathrm{yr}$ & Hours per year \\
\hline in. & Inch \\
\hline LCS & Laboratory control sample \\
\hline LANL & Los Alamos National Laboratory \\
\hline LLNL & Lawrence Livermore National Laboratory \\
\hline $\mathrm{m}$ & Meter \\
\hline $\mathrm{m}^{2}$ & Square meter \\
\hline MDC & Minimum detectable concentration \\
\hline $\mathrm{mg} / \mathrm{kg}$ & Milligrams per kilogram \\
\hline $\mathrm{mg} / \mathrm{L}$ & Milligrams per liter \\
\hline $\mathrm{mi}$ & Mile \\
\hline
\end{tabular}




\section{List of Acronyms and Abbreviations (Continued)}

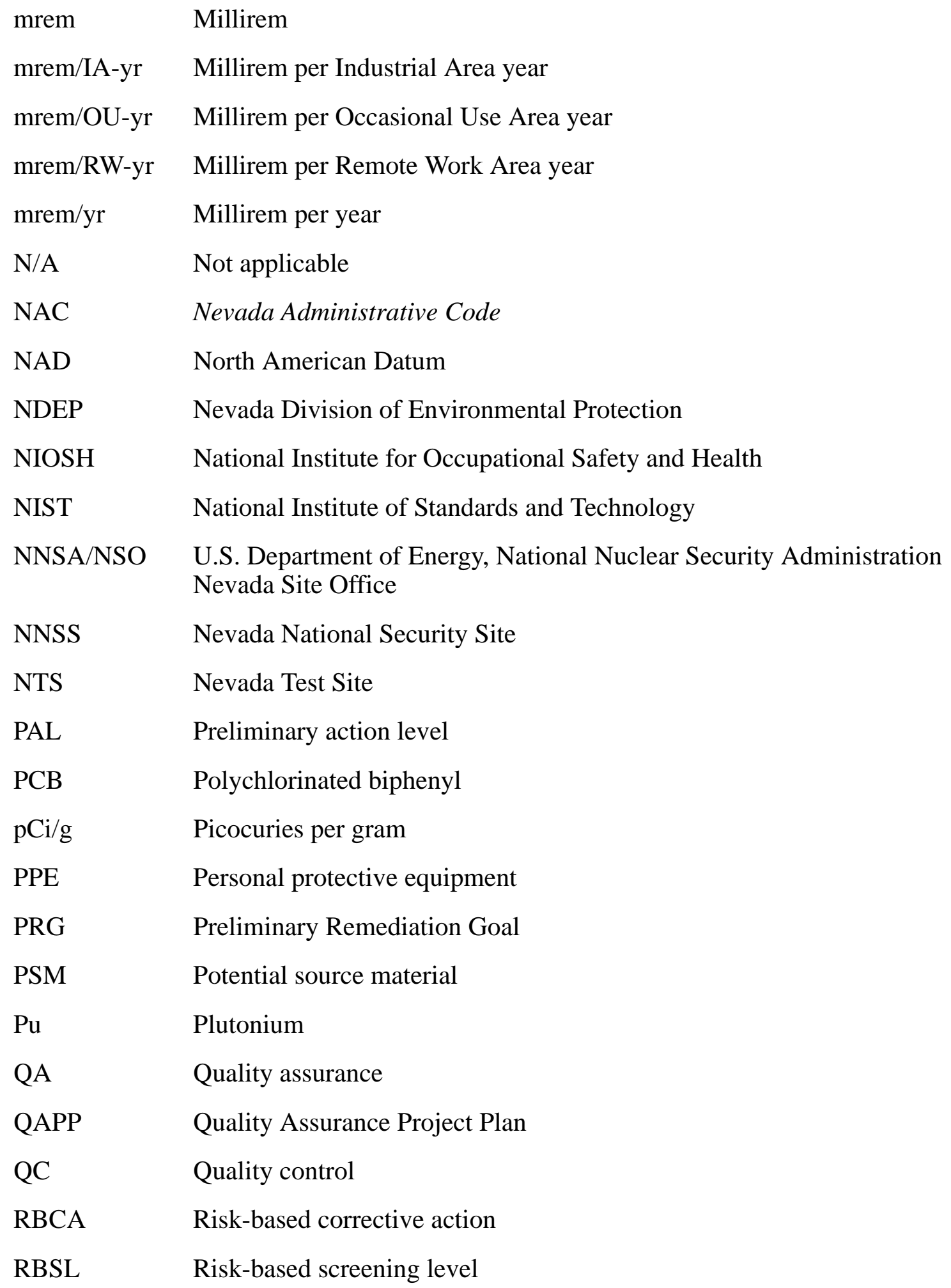




\section{List of Acronyms and Abbreviations (Continued)}

$\begin{array}{ll}\text { RCRA } & \text { Resource Conservation and Recovery Act } \\ \text { RIDP } & \text { Radionuclide Inventory and Distribution Program } \\ \text { RPD } & \text { Relative percent difference } \\ \text { RRMG } & \text { Residual radioactive material guideline } \\ \text { SDG } & \text { Sample delivery group } \\ \text { Sr } & \text { Strontium } \\ \text { SSTL } & \text { Site-specific target level } \\ \text { SVOC } & \text { Semivolatile organic compound } \\ \text { TBD } & \text { To be determined } \\ \text { TCLP } & \text { Toxicity Characteristic Leaching Procedure } \\ \text { TED } & \text { Total effective dose } \\ \text { Th } & \text { Thorium } \\ \text { TLD } & \text { Thermoluminescent dosimeter } \\ \text { U } & \text { Uranium } \\ \text { UCL } & \text { Upper confidence limit } \\ \text { UR } & \text { Use restriction } \\ \text { UTM } & \text { Universal Transverse Mercator } \\ \text { VOC } & \text { Volatile organic compound } \\ \text { VSP } & \text { Visual Sample Plan } \\ \text { yd } & \end{array}$




\section{Executive Summary}

This Corrective Action Decision Document/Closure Report has been prepared for Corrective Action Unit (CAU) 367, Area 10 Sedan, Ess and Uncle Unit Craters, located within Area 10 at the Nevada National Security Site, Nevada, in accordance with the Federal Facility Agreement and Consent Order (FFACO). Corrective Action Unit 367 comprises four corrective action sites (CASs):

- 10-09-03, Mud Pit

- 10-45-01, U-10h Crater (Sedan)

- 10-45-02, Ess Crater Site

- 10-45-03, Uncle Crater Site

The purpose of this Corrective Action Decision Document/Closure Report is to provide justification and documentation of the corrective actions and site closure activities implemented at CAU 367. A corrective action of closure in place with use restrictions was completed at each of the three crater CASs (10-45-01, 10-45-02, and 10-45-03); corrective actions were not required at CAS 10-09-03. In addition, a limited soil removal corrective action was conducted at the location of a potential source material release. Based on completion of these correction actions, no additional corrective action is required at CAU 367, and site closure is considered complete. Corrective action investigation (CAI) activities were performed from February 2010 through March 2011, as set forth in the Corrective Action Investigation Plan for Corrective Action Unit 367: Area 10 Sedan, Ess and Uncle Unit Craters, Nevada Test Site, Nevada.

The approach for the CAI was divided into two facets: investigation of the primary release of radionuclides, and investigation of non-test or other releases (e.g., migration in washes and potential source material). Based on the proximity of the Uncle, Ess, and Sedan craters, the impact of the Sedan test on the fallout deposited from the two earlier tests, and aerial radiological surveys, the CAU 367 investigation was designed to study the releases from the three crater CASs as one combined release (primary release). Corrective Action Site 10-09-03, Mud Pit, consists of two mud pits identified at CAU 367. The mud pits are considered non-test releases or other releases and were investigated independent of the three crater CASs. The purpose of the CAI was to fulfill data needs as defined during the data quality objective (DQO) process. The CAU 367 dataset of investigation results was evaluated based on a data quality assessment. This assessment demonstrated the dataset is complete and acceptable for use in fulfilling the DQO data needs. 
Analytes detected during the CAI were evaluated against final action levels (FALs) established in this document. For the primary release, radiological doses exceeding the FAL of 25 millirem per year were not found to be present in the surface or shallow subsurface soil outside the default contamination boundary. However, it was assumed that radionuclides are present in subsurface media within each of the three craters (Sedan, Ess, and Uncle) due to prompt injection of radionuclides from the tests. Based on the assumption of radiological dose exceeding the FAL, corrective actions were undertaken that consisted of implementing a use restriction and posting warning signs at each crater CAS. These use restrictions were recorded in the FFACO database; the U.S. Department of Energy, National Nuclear Security Administration Nevada Site Office (NNSA/NSO) Facility Information Management System; and the NNSA/NSO CAU/CAS files.

With regard to other releases, no contaminants of concern were identified at the mud pits or any of the other release locations, with one exception. Potential source material in the form of lead was found at one location. A corrective action of clean closure was implemented at this location, and verification samples indicated that no further action is necessary.

Therefore, NNSA/NSO provides the following recommendations:

- A Notice of Completion to NNSA/NSO is requested from the Nevada Division of Environmental Protection for closure of CAU 367.

- Corrective Action Unit 367 should be promoted from Appendix III to Appendix IV of the FFACO. 


\subsection{Introduction}

This Corrective Action Decision Document (CADD)/Closure Report (CR) presents information supporting closure of Corrective Action Unit (CAU) 367, Area 10 Sedan, Ess and Uncle Unit Craters, located at the Nevada National Security Site (NNSS) (formerly the Nevada Test Site), Nevada. The corrective actions described in this document were implemented in accordance with the Federal Facility Agreement and Consent Order (FFACO) (1996, as amended) that was agreed to by the State of Nevada; U.S. Department of Energy (DOE), Environmental Management; U.S. Department of Defense; and DOE, Legacy Management. The NNSS is located approximately 65 miles (mi) northwest of Las Vegas, Nevada.

Corrective Action Unit 367 consists of the four corrective action sites (CASs) shown on Figure 1-1 and listed below:

- 10-09-03, Mud Pit

- 10-45-01, U-10h Crater (Sedan)

- 10-45-02, Ess Crater Site

- 10-45-03, Uncle Crater Site

Corrective Action Sites 10-45-01, 10-45-02, and 10-45-03 consist of the release of radionuclides to surrounding soil from the Sedan, Ess, and Uncle tests, respectively. These three CASs are collectively referred to as the "crater CASs" throughout this document. The Sedan test was detonated in 1962, the Ess test in 1955, and the Uncle test in 1951 (DOE/NV, 2000b). Each of the three test devices was detonated underground and resulted in the ejection of soil and rock to form a surface crater. These releases resulted in the contamination of material in the associated crater, in the ejecta piles surrounding the crater, and on the soil surface from atmospheric deposition of radioactive material. Based on the proximity of the craters, the impact of the Sedan test on the fallout deposited from the two earlier tests, and aerial radiological surveys, the CAU 367 investigation was designed to study the releases from the three crater CASs as one combined release (referred to as the primary release).

Corrective Action Site 10-09-03, Mud Pit, includes two mud pits at CAU 367. The Ess mud pit was identified in the Corrective Action Investigation Plan (CAIP) for Corrective Action Unit 367: Area 10 Sedan, Ess and Uncle Unit Craters, Nevada Test Site, Nevada (NNSA/NSO, 2009), and is 


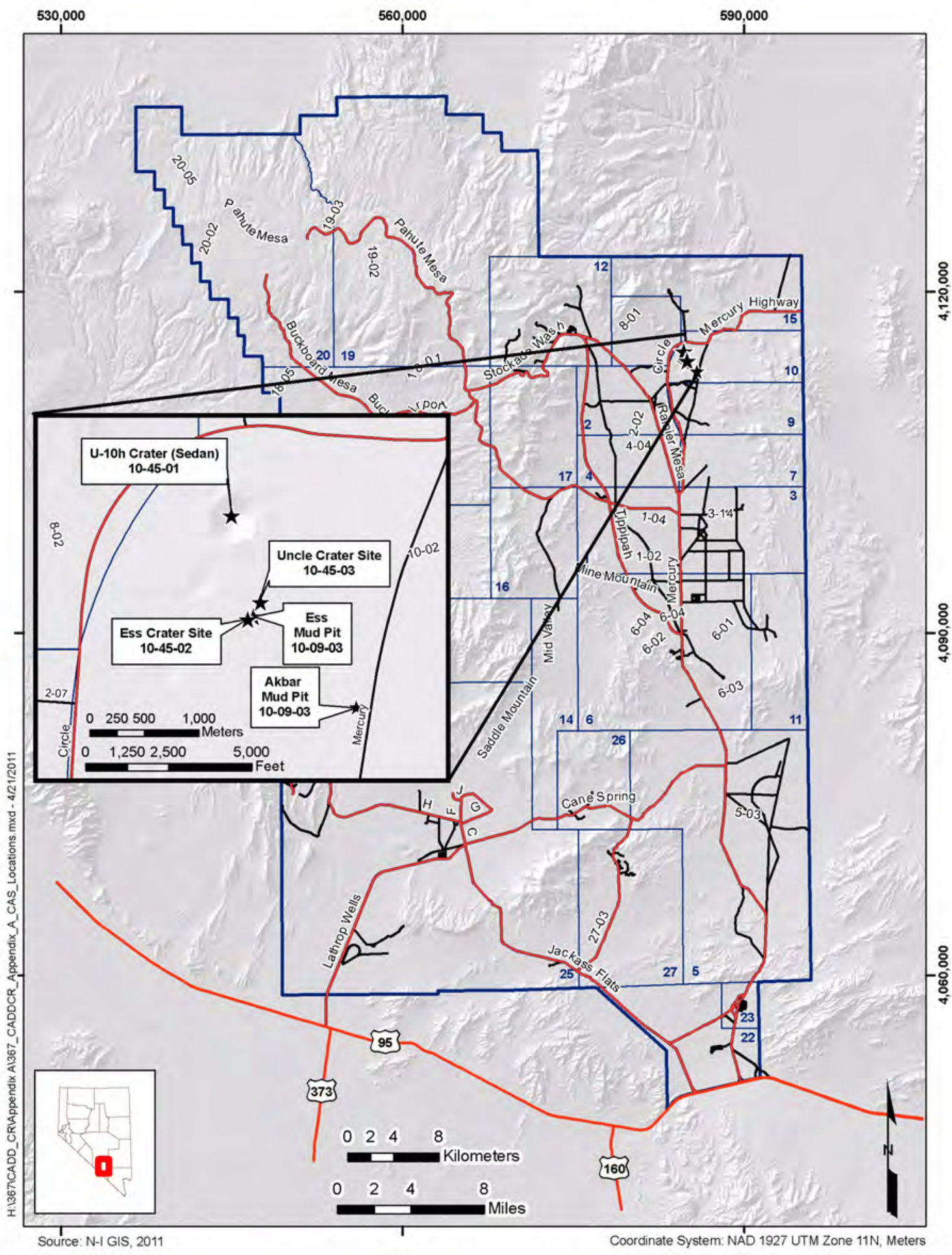

Figure 1-1

CAU 367, CAS Location Map 
located at the bottom of the Ess crater. This mud pit consists of mud material likely associated with post-test drilling (DOE, 1990). The second mud pit was identified during the corrective action investigation (CAI) for CAU 367 and is located adjacent to the U-10ax crater (Akbar) southeast of the Ess crater. The mud pits are considered non-test releases (herein referred to as “other releases”) and are discussed independent of the three crater CASs.

A detailed discussion of the history of this CAU is presented in the CAU 367 CAIP (NNSA/NSO, 2009). The CAIP provides information relating to site history as well as the scope and planning of the investigation. Therefore, this information is not repeated in this document.

\subsection{Purpose}

This report provides documentation and justification for the closure of CAU 367, including a description of investigation activities, an evaluation of the data, and a description of the corrective actions implemented. The corrective actions included closure in place with use restrictions (URs) and removal of potential source material (PSM) and associated soil contamination. Based on completion of these corrective actions, no further corrective action is necessary at CAU 367.

\subsection{Scope}

The CAI for CAU 367 was completed by identifying, through soil and thermoluminescent dosimeter (TLD) sample analytical results, the nature and extent of contaminants of concern (COCs) at the CAU 367 CASs.

As indicated in the CAIP, the collection of samples was not feasible within the default contamination boundary, which includes the crater and ejecta mounds at each crater CAS. As such, it was necessary to assume that COCs are present in the subsurface within the default contamination boundary at the three crater CASs.

The scope of the investigation activities at CAU 367 included performing visual surveys, collecting environmental and quality control (QC) samples, placing TLDs, and completing ground-based radiological surveys. The scope of the corrective action activities included evaluating corrective action alternatives (CAAs), removing PSM, establishing and posting URs, and documenting and justifying closure activities. 
The extent of CAU 367 includes the areas impacted by the three underground detonations, as indicated by the aerial radiological survey (NNSA/NSO, 2010) and the results of the CAI. There are two fenced areas located near the western edge of the contamination plume (west of the Sedan crater near Circle Road) that are posted Contamination Areas (see demarcation lines in Figure A.2-1). The large fenced area located west of Circle Road was delineated and posted in 1998 and is associated with the Smoky nuclear test and three safety experiments (Oberon, Ceres, and Titania). The smaller fenced area located east of Circle Road was identified in 2004 while the area was being surveyed for surface migration from the larger area. These fenced areas were not part of the CAU 367 investigation, as they are associated with the surface radiological contamination produced by the tests conducted to the west of CAU 367 (DOE/NV, 2000a). As a result, these areas are not discussed further in this report.

Three PSM locations were identified during the course of the CAU 367 investigation. These three locations include two tar locations and one lead/steel shot location. All three sites will be transferred to and addressed in CAU 548, Areas 9, 10, 18, 19, and 20 Housekeeping Sites. The results of the samples collected at these sites are presented in this document for completeness; however, no corrective action decisions were made based on these data.

\subsection{CADD/CR Contents}

This document is divided into the following sections and appendices:

Section 1.0, “Introduction,” summarizes the document purpose, scope, and contents.

Section 2.0, “Corrective Action Investigation Summary,” summarizes the investigation field activities and the results of the investigation, and justifies that no further corrective action is needed.

Section 3.0, "Recommendation,” provides the basis for requesting that the CAU be moved from Appendix III to Appendix IV of the FFACO.

Section 4.0, "References,” provides a list of all referenced documents used in the preparation of this CADD/CR. 
Appendix A, Corrective Action Investigation Results, provides a description of the project objectives, field investigation and sampling activities, investigation results, waste management, and quality assurance (QA). Sections A.3.0 and A.4.0 provide CAS-specific information regarding field activities, sampling methods, and laboratory analytical results from the investigation.

Appendix B, Data Assessment, provides a data quality assessment (DQA) that reconciles data quality objective (DQO) assumptions and requirements to the investigation results.

Appendix C, Risk Assessment, presents an evaluation of risk associated with the establishment of final action levels (FALs).

Appendix D, Closure Activity Summary (Use Restrictions), provides details on the completed closure activities, and includes the required verification activities and supporting documentation.

Appendix E, Evaluation of Corrective Action Alternatives, provides a summary of the results of the CAI, the alternatives considered, and the rationale for the recommended alternative.

Appendix F, Composite Sample Plot Analytical Data, provides tabular compilations of validated analytical results that provide a basis for the internal radiological dose estimates, and the tabular compilations of TLD sample data that provide a basis for the external radiological dose.

Appendix G, Sample Location Coordinates, presents the northing and easting coordinates for each sample plot, TLD location, and other release sampling location.

Appendix H, Nevada Division of Environmental Protection (NDEP) Comments, contains NDEP comments on the draft version of this document.

\subsection{Applicable Programmatic Plans and Documents}

All investigation activities were performed in accordance with the CAIP for CAU 367

(NNSA/NSO, 2009), FFACO (1996, as amended), and Industrial Sites Quality Assurance Project Plan (QAPP) (NNSA/NV, 2002).

The CAIP for CAU 367 contains the DQOs as agreed to by stakeholders prior to the field investigation. The DQO process ensures that the right type, quality, and quantity of data will be 
available to support the resolution of those decisions with an appropriate level of confidence. A DQA was conducted to evaluate the degree of acceptability and usability of the reported data in the decision-making process. This DQA summary is presented in Appendix B and summarized in Section 2.2.2. Using both the DQO and DQA processes helps ensure that DQO decisions are sound and defensible.

Based on this evaluation, the nature and extent of COCs at CAU 367 have been adequately identified to implement the corrective actions. Information generated during the investigation supports the conceptual site model (CSM) assumptions, and the data collected meet the DQOs and support their intended use in the decision-making process. 


\subsection{Corrective Action Investigation Summary}

The following sections summarize the CAI and results, provide the rationale for implementing closure in place with URs, and justify why no further corrective action is required at CAU 367. Detailed investigation activities and results of the CAI are presented in Appendix A of this document.

\section{$2.1 \quad$ Investigation Activities}

Corrective action investigation activities were conducted as set forth in the CAU 367 CAIP (NNSA/NSO, 2009) from February 2010 to March 2011. The investigation activities were conducted in accordance with the CAIP except as noted herein. The objective of the CAU 367 CAI was to provide the additional information needed to resolve the following project-specific DQOs:

- $\quad$ Determine whether COCs are present in the soils associated with CAU 367.

- Determine the nature and extent of identified COCs.

- Ensure adequate data are collected to evaluate CAAs and meet the requirements of the FFACO.

The scope of the CAI included the following field activities:

- Performance of visual surveys to identify PSM.

- Staging of TLDs at soil sample plots, background locations, and other locations of interest.

- Performance of ground-based radiological surveys.

- Establishment of sample plots and composite sample aliquot locations.

- Collection of surface and shallow subsurface soil samples.

- Submittal of soil samples for offsite laboratory analysis.

- Collection of Global Positioning System (GPS) coordinates of soil sample and TLD locations.

- Collection and submittal of TLDs for analysis.

To facilitate site investigation and the evaluation of DQO decisions for different CSM components, the releases at each CAS were classified into one of the following two categories:

- Primary releases (referred to as “Test Releases” in the CAIP)—This release category is specific to the atmospheric deposition of radionuclide contamination onto the soil surface (i.e., fallout) that has not been displaced through excavation or migration. Primary releases are investigated via a combination of external dose assessment using TLDs and internal dose assessment through the collection and analysis of soil samples. Due to the potential layering 
of contamination from the Sedan, Ess, and Uncle tests, shallow subsurface radionuclide contamination is also considered part of the primary release.

- Other releases (referred to as "Non-test Releases" in the CAIP)—This release category includes releases not considered primary releases and may include any of the following:

- Radionuclide contaminants that were initially deposited onto the soil surface by the primary release but have subsequently been displaced through excavation or migration.

- Radionuclides deposited under mechanisms other than atmospheric deposition to include the injection of radionuclides into native material from the nuclear detonation (prompt injection) and the deposition of ejecta piles around a crater.

- Any other chemical or radiological contamination discovered during the investigation that is not a part of a previously identified release.

Judgmental sample locations for investigation of the primary release were established based on the four-vector sampling approach outlined in the CAIP and illustrated in Figure A.2-1. The four vectors, herein referred to as the east, south, northwest, and northeast vectors, and the sample plots on each vector were established based primarily on the interpretation of aerial radiological survey data and ground-based radiological surveys. At each sample plot, probabilistic sample locations were established based on a randomized grid. For other releases, judgmental sample locations were determined based on biasing criteria such as elevated radiological readings, PSM, and stained soil.

Confidence in judgmental sampling scheme decisions was established qualitatively through validation of the CSM and verification that the selected plot locations meet the DQO criteria. Confidence in probabilistic sampling scheme decisions was established by validating the CSM, justifying that sampling locations are representative of the plot area, and demonstrating that the number of samples collected was sufficient to justify statistical inferences (e.g., averages and 95 percent upper confidence limits [UCLs]).

As described in Appendix C, the radiological dose to a receptor is a function of the time the receptor is present at the site and exposed to the radioactively contaminated soil. Therefore, radiological dose is reported in this document based on the following three exposure scenarios:

- Industrial Area-Assumes continuous industrial use of a site. This scenario addresses exposure to industrial workers exposed daily to contaminants in soil during an average workday. This scenario assumes that this is the regular assigned work area for the worker who 
will be on the site for an entire career (225 days per year [day/yr], 10 hours per day [hr/day] for 25 years). The total effective dose (TED) values calculated using this exposure scenario are the TED an industrial worker receives during 2,250 hours of annual exposure to site radioactivity and are expressed in terms of millirem per Industrial Area year (mrem/IA-yr).

- Remote Work Area-Assumes noncontinuous work activities at a site. This scenario addresses exposure to industrial workers exposed to contaminants in soil during a portion of an average workday. This scenario assumes that this is an area where the worker regularly visits but is not an assigned work area where the worker spends an entire workday. A site worker under this scenario is assumed to be on the site for an equivalent of 336 hours per year (hr/yr) (or $8 \mathrm{hr} /$ day for 42 day/yr) for an entire career (25 years). The TED values calculated using this exposure scenario are the TED a remote area worker receives during 336 hours of annual exposure to site radioactivity and are expressed in terms of millirem per Remote Work Area year (mrem/RW-yr).

- Occasional Use Area-Assumes occasional work activities at a site. This scenario addresses exposure to industrial workers who are not assigned to the area as a regular worksite but may occasionally use the site. This scenario assumes that this is an area where the worker does not regularly visit but may occasionally use for short-term activities. A site worker under this scenario is assumed to be on the site for an equivalent of $80 \mathrm{hr} / \mathrm{yr}$ (or $8 \mathrm{hr} /$ day for 10 day/yr) for 5 years. The TED values calculated using this exposure scenario are the TED an occasional use worker receives during 80 hours of annual exposure to site radioactivity and are expressed in terms of millirem per Occasional Use Area year (mrem/OU-yr).

The potential external dose at each TLD location was determined from the results of a TLD placed at a height of 1 meter (m) above the soil surface. The net external dose (the gross TLD dose reading minus the background dose) was then divided by the number of hours the TLD was exposed to site contamination, resulting in an hourly dose rate. The hourly dose rate was then multiplied by the number of hours per year that a site worker would be present at the site (i.e., the annual exposure duration) to establish the potential annual external dose. The appropriate annual exposure duration in hours is based on the exposure scenario used.

The potential internal dose at each sample location was determined based on the analytical results of soil samples and residual radioactivity material guidelines (RRMGs) that were calculated using the RESRAD computer code (Yu et al., 2001) (see Attachment C-1). The RRMGs are the activity concentrations of individual radionuclides in surface soil that would cause a receptor to receive an internal dose equal to the radiological FAL. The internal doses from each of the radionuclides are then summed to produce the total potential internal dose. 
The potential internal dose at each TLD location where soil samples were not collected was conservatively estimated using the potential external dose from the TLD and the ratio of internal dose to external dose from the sample plot with the maximum internal dose. This was done under the conservative assumption that the internal dose at any CAU 367 location would constitute the same percentage of the total dose as at the plot where the maximum internal dose was observed. Therefore, the ratio of the internal to external dose was determined at the plot with the highest internal dose by dividing the internal dose by the external dose. This ratio was then multiplied by the external dose measured at each TLD location where soil samples were not collected to estimate the internal dose at that location.

The calculated TED (the sum of internal and external dose) for each sample location is an estimation of the true radiological dose (true TED). The TED is defined in Title 10 of the Code of Federal Regulations (CFR), Part 835 (CFR, 2010) as the sum of the effective dose (for external exposures) and the committed effective dose (for internal exposures).

Because a measured TED is an estimate of the true (unknown) TED, it is uncertain how well the calculated TED represents the true TED. If the measured TED were significantly different from the true TED, a decision based on the measured TED could result in a decision error. To reduce the probability of making a false negative decision error, a conservative estimate of the true TED is used to compare to the FAL instead of the measured TED where sufficient sample data are available. This conservative estimate (overestimation) of the true TED was calculated as the 95 percent UCL of the average TED measurements. By definition, there will be a 95 percent probability that the true TED is less than the 95 percent UCL of the measured TED.

The following sections describe specific investigation activities conducted at the primary release (i.e., the crater CASs) and other release locations. Additional information regarding the investigation is presented in Appendix A.

\subsubsection{Primary Release}

The three crater CASs, 10-45-01 (Sedan crater), 10-45-02 (Ess crater), and 10-45-03 (Uncle crater), were investigated as one primary release, rather than three individual releases. This investigative approach was selected based on historical information suggesting that the area of the Sedan release 
encompassed the Uncle and Ess test releases. Historical video footage of the Sedan test shows the base surge scouring and lifting surface soil out to a diameter of $5 \mathrm{mi}$ from Sedan ground zero (AEC, 1962). Presumably, this soil would have covered the ejecta and fallout from the two smaller tests (Uncle and Ess) conducted prior to the Sedan test. In addition, two aerial radiological surveys conducted at CAU 367 in 1994 and 2009 suggest a single, large contamination plume originating from the Sedan site (BN, 1999; NNSA/NSO, 2010).

The primary release at the three crater CASs was investigated utilizing a combination of aerial and ground-based radiological measurements, external dose assessment using TLDs, and internal dose assessment using soil sample results. These data, coupled with historical information and data obtained in previous studies, formed the basis for site closure decisions. Refer to Section A.3.1 for additional information on investigation activities.

\subsubsection{Other Releases}

Three specific site features requiring investigation were identified as other releases in the CAIP: sediment accumulation areas within site drainages; an area along the shoulder of Circle Road northwest of the Sedan crater; and the Ess mud pit (CAS 10-09-03). The second mud pit in CAS 10-09-03 (Akbar mud pit) was identified during the CAI. In addition to the specific features, several items identified as PSM were investigated as other releases. Refer to Section A.3.1 for additional information on investigation activities.

\subsubsection{Drainages}

A ground-based visual survey of CAU 367 was conducted to identify drainages and other surface conduits with the potential to serve as migration pathways for radioactive contamination. The CAIP identified the nearest drainage feature to the Sedan crater as being located east of the crater; however, the presence of this feature was not confirmed by the visual survey. In fact, the survey did not identify any drainage features and associated sedimentation areas where contamination from the primary release might concentrate. Instead, the pattern suggested by the site topography is that surface water flows overland until it intercepts a depression or crater, at which time the water flows into the crater or flow is impeded by the crater rim. Because no drainage features were identified that 
would provide a pathway for migration beyond the CAU boundary, this migration pathway is not considered complete, and no sampling of such features was conducted during the CAI.

\subsubsection{Mercury Highway/Circle Road}

An area along Circle Road (referred to as Mercury Highway in the CAIP) was identified as a potential other release in the CAIP based on the 1994 aerial survey of CAU 367 (BN, 1999). This survey suggested an area of elevated radioactivity in the region northwest of the Sedan crater. The 2009 aerial survey confirmed the results of the earlier survey (NNSA/NSO, 2010).

The purpose of investigating this area was to determine the highest dose that might be received by a motorist stopped on the roadside or a site worker conducting road maintenance. In order to determine the highest areas of radioactivity along this stretch of road, a ground-based radiological survey was conducted using the PRM-470 instrument. Soil samples were collected at two judgmental sampling locations (XH01 and XH02) identified by the survey.

\subsubsection{CAS 10-09-03, Mud Pit}

Corrective Action Site 10-09-03 consists of two mud pits: the Ess mud pit and the Akbar mud pit. The Ess mud pit is located at the bottom of the Ess crater and consists of the release of bentonite clay material presumably used in post-test drilling operations associated with the Ess test (DOE, 1990). The Ess mud pit is categorized as a Los Alamos National Laboratory (LANL) post-test mud pit in accordance with the Mud Pit Risk-Based Closure Strategy Report (NNSA/NSO, 2004). The investigation of the Ess mud pit involved the collection of samples of the material from the center of the mud (sample location XM01). The Akbar mud pit is located 1,200 m southeast of the Ess mud pit. This mud pit consists of the release of bentonite clay material deposited during drilling of the U-10ax (Akbar test) emplacement borehole. The Akbar mud pit is categorized as a Lawrence Livermore National Laboratory (LLNL) pretest mud pit in accordance with the Mud Pit Risk-Based Closure Strategy Report (NNSA/NSO, 2004). Corrective action investigation activities at the Akbar mud pit included a visual survey of the mud pit and the collection of GPS coordinates. No samples were collected at the Akbar mud pit. 


\subsubsection{Potential Source Material}

A visual survey of the area encompassed by CAU 367 was conducted to identify locations of potential releases and PSM. Several items were inventoried, including large and small metal fragments, batteries, empty containers, construction rubble piles, lead and steel shot, and tar pieces. The debris items were evaluated, using process knowledge, radiological surveys, and/or sampling, for their potential to release contaminants to the environment and/or provide a radiological dose to a receptor.

Potential source material was identified at eight locations: three sites containing tar pieces, three battery sites, one lead and steel shot site, and one empty 1-gallon paint container site. A total of 13 soil samples were collected from the debris item locations (see Table A.4-3). As stated in Section 1.2, two of the tar locations and the lead/steel shot location will be transferred to CAU 548, Areas 9, 10, 18, 19, and 20 Housekeeping Sites. The results of the samples collected at these three sites are included in Section A.4.4.2 for completeness. The investigation and evaluation of corrective actions for these sites will be addressed under CAU 548.

\subsection{Results}

This section summarizes the results of the CAI of the primary release and other releases at CAU 367. Detailed information regarding the investigation results is presented in Appendix A. The radiological results for both the primary and other releases are reported as doses that are compared to the dose-based FAL as established in Appendix C. The chemical results from other releases are reported as individual concentrations that are compared to the individual FALs as established in Appendix C.

\subsubsection{Summary of Analytical Data}

A total of 72 soil samples (68 surface, 4 subsurface) were collected from 16 sample plots in the investigation of the primary release (see Table A.3-1). A total of 68 TLDs were installed during the investigation at CAU 367: 65 measured external dose from the primary release (environmental TLDs), and 3 measured background activity (background TLDs) (see Table A.3-2). Sample locations were established based on visual and radiological biasing factors. Grab soil samples were collected at the other release locations, but TLDs were not staged at these locations. 


\section{Primary Release}

The internal dose calculated from soil sample results and the external dose calculated from TLD measurements were combined to determine the TED at each primary release sample location. The primary release results are reported as doses that are compared to the dose-based preliminary action level (PAL) of 25 mrem/IA-yr and the FAL of 25 mrem/RW-yr. The PALs were established in the CAIP (NNSA/NSO, 2009) based on a dose limit of 25 millirem per year (mrem/yr) over an annual exposure time of 2,250 hours (i.e., the Industrial Area exposure scenario that a site worker would be exposed to site contamination for $10 \mathrm{hr} /$ day for 225 day/yr). The FALs in Appendix C were established based on a dose limit of 25 mrem/yr over an annual exposure time of 336 hours (i.e., the Remote Work Area exposure scenario that a site worker would be exposed to site contamination $8 \mathrm{hr} /$ day for 42 day/yr). The Occasional Use Area exposure scenario was not considered in evaluating corrective actions at CAU 367 (see Section 2.3.1).

The average TED values and the 95 percent UCL of the TED for the Industrial Area, Remote Work Area, and Occasional Use Area exposure scenarios are presented in Table 2-1. Based on the data evaluation using the Remote Work Area exposure scenario, the FAL was not exceeded at any sample location (see Figure A.3-6). As a result, no COCs were identified at any of the three crater CASs outside the default contamination boundary. The default contamination boundary was defined in the CAIP as the area of the crater, crater rim, and related mounding around the crater that was assumed to exceed the FAL, and require corrective action. This assumption was based on knowledge of the three tests which suggests that much of the radioactivity associated with the tests was captured within the craters (i.e., prompt injection). The default contamination boundaries at each of the three crater CASs were determined through a ground-based visual survey of the ejecta mounds surrounding each crater.

The TED values for the crater CASs were also compared to the PAL of 25 mrem/IA-yr established in the CAIP. As indicated in Figure A.3-7 and Table 2-1, the PAL is exceeded at 24 sample locations. The surface location at which the maximum TED was measured was sample plot $\mathrm{K}$ on the south vector between the Uncle and Ess craters (see Figure A.2-1). A receptor would have to be exposed to this location for 621 hours to receive a dose of 25 millirem (mrem).

The CSM for the primary release is provided in the CAIP. Information gathered during the CAI supports and validates the CSM as presented in the CAIP. No modification to the CSM was needed. 
Table 2-1

Total Effective Dose at Primary Release Sample Locations (mrem/yr) (Page 1 of 3 )

\begin{tabular}{|c|c|c|c|c|c|c|c|}
\hline \multirow{2}{*}{$\begin{array}{l}\text { Sample } \\
\text { Plot }\end{array}$} & \multirow{2}{*}{$\begin{array}{c}\text { TLD } \\
\text { Location }\end{array}$} & \multicolumn{2}{|c|}{ Industrial Area } & \multicolumn{2}{|c|}{ Remote Work Area } & \multicolumn{2}{|c|}{ Occasional Use Area } \\
\hline & & $\begin{array}{l}\text { Average } \\
\text { Total }\end{array}$ & $\begin{array}{c}\text { 95\% UCL } \\
\text { Total }\end{array}$ & $\begin{array}{l}\text { Average } \\
\text { Total }\end{array}$ & $\begin{array}{c}95 \% \text { UCL } \\
\text { Total }\end{array}$ & $\begin{array}{c}\text { Average } \\
\text { Total }\end{array}$ & $\begin{array}{c}\text { 95\% UCL } \\
\text { Total }\end{array}$ \\
\hline$A$ & AT42 & 53.3 & 63.4 & 7.99 & 9.51 & 1.93 & 2.30 \\
\hline $\mathrm{B}$ & AT41 & 34 & 35.5 & 5.09 & 5.32 & 1.22 & 1.28 \\
\hline $\mathrm{C}$ & AT44 & 15.3 & 18.2 & 2.30 & 2.73 & 0.560 & 0.662 \\
\hline $\mathrm{D}$ & AT45 & 12.5 & 16.1 & 1.87 & 2.42 & 0.455 & 0.585 \\
\hline$E$ & AT33 & 57.4 & 61 & 8.61 & 9.15 & 2.09 & 2.22 \\
\hline $\mathrm{F}$ & AT34 & 64.5 & 72.7 & 9.69 & 10.9 & 2.35 & 2.65 \\
\hline G & AT36 & 35.7 & 40.7 & 5.39 & 6.14 & 1.33 & 1.52 \\
\hline $\mathrm{H}$ & AT39 & 10.6 & 14.3 & 1.60 & 2.16 & 0.393 & 0.531 \\
\hline $\mathrm{J}$ & AT24 & 54.7 & 58.3 & 8.19 & 8.73 & 1.97 & 2.10 \\
\hline $\mathrm{K}$ & AT55 & 90.6 & 95.5 & 13.6 & 14.3 & 3.25 & 3.44 \\
\hline $\mathrm{L}$ & AT28 & 67.8 & 78.4 & 10.1 & 11.7 & 2.42 & 2.80 \\
\hline $\mathrm{M}$ & AT30 & 3.66 & 7.36 & 0.548 & 1.1 & 0.131 & 0.263 \\
\hline $\mathrm{N}$ & AT01 & 40.5 & 51.1 & 6.08 & 7.67 & 1.48 & 1.86 \\
\hline $\mathrm{P}$ & AT02 & 26.8 & 30.1 & 4.02 & 4.51 & 0.971 & 1.09 \\
\hline $\mathrm{Q}$ & AT03 & $0^{a}$ & 4.46 & $0^{a}$ & 0.669 & $0^{a}$ & 0.161 \\
\hline $\mathrm{R}$ & AT05 & 21.8 & 23.7 & 3.29 & 3.59 & 0.814 & 0.892 \\
\hline No plot & AT04 & 3.06 & 8.05 & 0.461 & 1.22 & 0.114 & 0.30 \\
\hline No plot & AT06 & 13.6 & 24.9 & 2.05 & 3.76 & 0.506 & 0.927 \\
\hline No plot & AT07 & 8.34 & 11.9 & 1.26 & 1.8 & 0.311 & 0.445 \\
\hline No plot & AT08 & 0.195 & 5.22 & 0.030 & 0.787 & 0.007 & 0.194 \\
\hline No plot & AT09 & 10.5 & 12.5 & 1.58 & 1.88 & 0.391 & 0.465 \\
\hline No plot & AT10 & 26.6 & 36.3 & 4.02 & 5.48 & 0.994 & 1.35 \\
\hline No plot & AT11 & 24.7 & 28.3 & 3.72 & 4.28 & 0.92 & 1.06 \\
\hline No plot & AT12 & 27.1 & 31.8 & 4.09 & 4.8 & 1.01 & 1.18 \\
\hline No plot & AT13 & 17.7 & 18.5 & 2.68 & 2.79 & 0.661 & 0.690 \\
\hline No plot & AT14 & 9.65 & 10.7 & 1.46 & 1.61 & 0.360 & 0.398 \\
\hline No plot & AT15 & $0^{a}$ & 2.12 & $0^{a}$ & 0.32 & $0^{a}$ & 0.079 \\
\hline
\end{tabular}


Table 2-1

Total Effective Dose at Primary Release Sample Locations (mrem/yr) (Page 2 of 3 )

\begin{tabular}{|c|c|c|c|c|c|c|c|}
\hline \multirow{2}{*}{$\begin{array}{l}\text { Sample } \\
\text { Plot }\end{array}$} & \multirow{2}{*}{$\begin{array}{c}\text { TLD } \\
\text { Location }\end{array}$} & \multicolumn{2}{|c|}{ Industrial Area } & \multicolumn{2}{|c|}{ Remote Work Area } & \multicolumn{2}{|c|}{ Occasional Use Area } \\
\hline & & $\begin{array}{l}\text { Average } \\
\text { Total }\end{array}$ & $\begin{array}{c}\text { 95\% UCL } \\
\text { Total }\end{array}$ & $\begin{array}{l}\text { Average } \\
\text { Total }\end{array}$ & $\begin{array}{c}\text { 95\% UCL } \\
\text { Total }\end{array}$ & $\begin{array}{c}\text { Average } \\
\text { Total }\end{array}$ & $\begin{array}{c}\text { 95\% UCL } \\
\text { Total }\end{array}$ \\
\hline No plot & AT16 & 3.81 & 9.34 & 0.576 & 1.41 & 0.142 & 0.348 \\
\hline No plot & AT17 & 4.33 & 6.45 & 0.654 & 0.974 & 0.162 & 0.240 \\
\hline No plot & AT18 & 10.2 & 13.3 & 1.55 & 2.01 & 0.382 & 0.496 \\
\hline No plot & AT19 & 1.32 & 3.8 & 0.199 & 0.574 & 0.049 & 0.142 \\
\hline No plot & AT20 & 25.5 & 27.4 & 3.86 & 4.14 & 0.953 & 1.02 \\
\hline No plot & AT21 & 25.6 & 31.3 & 3.87 & 4.72 & 0.955 & 1.17 \\
\hline No plot & AT22 & 18.1 & 20.9 & 2.73 & 3.15 & 0.673 & 0.777 \\
\hline No plot & AT23 & 9.92 & 16.1 & 1.50 & 2.43 & 0.37 & 0.599 \\
\hline No plot & AT25 & 50.1 & 53.7 & 7.57 & 8.11 & 1.87 & 2.00 \\
\hline No plot & AT26 & 52.8 & 54.9 & 7.97 & 8.29 & 1.97 & 2.05 \\
\hline No plot & AT27 & 5.25 & 7.67 & 0.793 & 1.16 & 0.196 & 0.286 \\
\hline No plot & AT29 & 54.8 & 59 & 8.28 & 8.9 & 2.05 & 2.20 \\
\hline No plot & AT31 & 18.3 & 22.5 & 2.76 & 3.4 & 0.681 & 0.840 \\
\hline No plot & AT32 & 8.30 & 9.79 & 1.25 & 1.48 & 0.310 & 0.365 \\
\hline No plot & AT35 & 50.3 & 53.7 & 7.60 & 8.1 & 1.88 & 2.00 \\
\hline No plot & AT37 & 28.6 & 36.9 & 4.33 & 5.57 & 1.07 & 1.37 \\
\hline No plot & AT38 & 22.0 & 32.5 & 3.33 & 4.91 & 0.822 & 1.21 \\
\hline No plot & AT40 & 8.54 & 12.2 & 1.29 & 1.85 & 0.319 & 0.456 \\
\hline No plot & AT43 & 27.9 & 32.6 & 4.22 & 4.91 & 1.04 & 1.21 \\
\hline No plot & AT46 & 9.61 & 11.4 & 1.45 & 1.73 & 0.359 & 0.427 \\
\hline No plot & AT47 & 12.2 & 15.4 & 1.84 & 2.33 & 0.455 & 0.575 \\
\hline No plot & AT48 & 7.67 & 9.98 & 1.16 & 1.51 & 0.286 & 0.372 \\
\hline No plot & AT49 & 26.3 & 30 & 3.97 & 4.53 & 0.981 & 1.12 \\
\hline No plot & AT50 & 14.8 & 19.2 & 2.23 & 2.9 & 0.552 & 0.716 \\
\hline No plot & AT51 & 49.8 & 60.9 & 7.52 & 9.2 & 1.86 & 2.27 \\
\hline No plot & AT53 & $0^{a}$ & 2.91 & $0^{a}$ & 0.439 & $0^{a}$ & 0.108 \\
\hline No plot & AT54 & 0.748 & 3.16 & 0.113 & 0.477 & 0.028 & 0.118 \\
\hline
\end{tabular}


Table 2-1

\section{Total Effective Dose at Primary Release Sample Locations (mrem/yr)}

(Page 3 of 3 )

\begin{tabular}{||c|c|c|c|c|c|c|c||}
\hline \multirow{2}{*}{$\begin{array}{c}\text { Sample } \\
\text { Plot }\end{array}$} & \multirow{2}{*}{$\begin{array}{c}\text { TLD } \\
\text { Location }\end{array}$} & \multicolumn{2}{|c|}{ Industrial Area } & \multicolumn{2}{c|}{ Remote Work Area } & \multicolumn{2}{c|}{ Occasional Use Area } \\
\cline { 3 - 8 } & & $\begin{array}{c}\text { Average } \\
\text { Total }\end{array}$ & $\begin{array}{c}95 \% \text { UCL } \\
\text { Total }\end{array}$ & $\begin{array}{c}\text { Average } \\
\text { Total }\end{array}$ & $\begin{array}{c}\text { 95\% UCL } \\
\text { Total }\end{array}$ & $\begin{array}{c}\text { Average } \\
\text { Total }\end{array}$ & $\begin{array}{c}\text { 95\% UCL } \\
\text { Total }\end{array}$ \\
\hline \hline No plot & AT56 & $0^{\mathrm{a}}$ & $0^{\mathrm{a}}$ & $0^{\mathrm{a}}$ & $0^{\mathrm{a}}$ & $0^{\mathrm{a}}$ & $0^{\mathrm{a}}$ \\
\hline No plot & AT57 & 4.65 & 6.37 & 0.702 & 0.962 & 0.173 & 0.237 \\
\hline No plot & AT59 & $0^{\mathrm{a}}$ & $0^{\mathrm{a}}$ & $0^{\mathrm{a}}$ & $0^{\mathrm{a}}$ & $0^{\mathrm{a}}$ & $0^{\mathrm{a}}$ \\
\hline
\end{tabular}

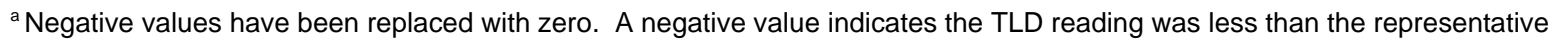
field background value.

Note: Bold indicates the value is greater than the FAL (25 mrem/yr). Values have been rounded to three significant digits.

\section{Other Releases}

No radiological or chemical COCs were identified at the Circle Road sample locations or at the Ess mud pit. Lead was detected in the soil at the location of a deteriorated lead-acid battery above the FAL of 800 milligrams per kilogram $(\mathrm{mg} / \mathrm{kg})$ at a concentration of 5,200 mg/kg. A soil removal corrective action was implemented at this location, and verification soil samples confirmed that the lead contamination was removed (see Section A.4.4.2).

The CSM and associated discussion for CAS 10-09-03 and the other releases are provided in the CAIP. Information gathered during the CAI supports and validates the CSM as presented in the CAIP. No modification to the CSM was needed.

\subsubsection{Data Assessment Summary}

The DQA is presented in Appendix B and includes an evaluation of the data quality indicators (DQIs) to determine the degree of acceptability and usability of the reported data in the decision-making process. The DQO process ensures that the right type, quality, and quantity of data are available to support the resolution of those decisions at an appropriate level of confidence. Using both the DQO and DQA processes help ensure that DQO decisions are sound and defensible. 
The DQA process consists of the following steps:

- Step 1: Review DQOs and Sampling Design.

- Step 2: Conduct a Preliminary Data Review.

- Step 3: Select the Test.

- Step 4: Verify the Assumptions.

- Step 5: Draw Conclusions from the Data.

The DQA determined that information generated during the investigation supports the CSM assumptions and that the data collected support their intended use in the decision-making process. Based on the results of the DQA presented in Appendix B, the DQO requirements have been met, and the nature and extent of COCs at CAU 367 have been adequately defined to implement corrective actions.

\subsection{Justification for No Further Action}

No further corrective action is required for the three crater CASs at CAU 367 based on implementation of the corrective action of closure in place with a UR at each of the three crater CASs. This corrective action was selected to ensure protection of the public and the environment in accordance with Nevada Administrative Code (NAC) 445A (NAC, 2010) and is based on an evaluation of risk, feasibility, and cost effectiveness (see Appendix E).

At the location of the lead-acid battery, a limited soil removal corrective action was implemented to remove lead contamination. Verification soil sample results confirmed that the contamination had been removed; thus, no further action is required at this location. No further action is required at any of the other release locations, because no chemical COCs were detected at the sites and the radiological dose calculated at these locations was below the FAL.

\subsubsection{Final Action Levels}

The establishment of the FALs (presented in Appendix C) was based on risk to receptors. The radiological risk to receptors from contaminants at CAU 367 is due to chronic exposure to radionuclides (i.e., receiving a dose over time). Therefore, the risk to a receptor is directly related to the amount of time a receptor is exposed to the contaminants. In the CAU 367 DQOs, it was determined that the Occasional Use Area exposure scenario would be appropriate in calculating receptor exposure time based on current land use at the CAU 367 CASs. In order to quantify the 
maximum number of hours a site worker may be present at CAU 367, current and anticipated future site activities were evaluated as part of the CAI (see Section C.1.10). This evaluation concluded that the most exposed worker under current land use is a tour escort that has the potential to be present at the Sedan crater for up to $96 \mathrm{hr} / \mathrm{yr}$. As a result, it was determined that the Occasional Use Area exposure scenario, which assumes an 80-hour annual exposure duration, does not conservatively encompass all potential exposure times under the current land use of the site. Using the average maximum dose measured at CAU 367, a receptor would have to be exposed to the location of maximum dose for 621 hours to receive a dose of 25 mrem. Thus, a receptor at the site for $336 \mathrm{hr} / \mathrm{yr}$ over 25 years (Remote Work Area scenario) would not exceed the 25-mrem/yr dose limit outside the default contamination boundary at any of the three crater CASs. As the most exposed worker under the current land use will not be exposed to site contamination for more than the length of time assumed for the Remote Work Area exposure scenario, it was decided to base the FALs on the Remote Work Area scenario (see Appendix C).

\subsubsection{Corrective Actions}

Corrective actions for the crater CASs were based on the risk assessment presented in Appendix C and the CAA evaluation presented in Appendix E. Based on the data evaluation using the Remote Work Area exposure scenario, no COCs were identified at any of the three crater CASs outside the default contamination boundary. Due to direct injection of radionuclides into the subsurface soil from the nuclear tests, however, it is assumed that subsurface contamination in excess of the FAL is present within each crater, at the crater rim, and in the surrounding ejecta mounds. Therefore, a corrective action of closure in place with a UR was implemented at each crater CAS to account for the subsurface contamination. The purpose of the FFACO URs established at the Sedan, Ess, and Uncle crater sites is to protect site workers and visitors from inadvertent exposure. The URs apply within an established boundary (FFACO UR boundary) that encircles the crater, crater rim, and related ejecta mounds around the crater (see Attachment D-2).

A limited soil removal corrective action was implemented at the location of a lead-acid battery release. Based on completion of this corrective action and the results of verification samples, no additional corrective action is required at CAU 367, and site closure is considered complete.

Further discussion of CAU 367 closure activities is presented in Appendix D. 


\subsubsection{Best Management Practices}

As a best management practice (BMP), an administrative UR was established to include the area where an industrial land use (2,250 hr/yr) could cause a future site worker to receive a dose exceeding 25 mrem/IA-yr. This administrative UR was established to prevent more intensive use of the site in the future, should land use at CAU 367 change. To determine the extent of this area, a process involving data collection and statistical analysis was implemented. This process is described in Section A.3.3, and the administrative UR boundary is presented in Attachment D-2.

The administrative UR at CAU 367 is not part of the corrective action, but was implemented as a BMP. In accordance with the Industrial Sites Project Establishment of Final Action Levels (NNSA/NSO, 2006), if the Remote Work Area or Occasional Use Area scenario is used for any site to calculate a FAL, an administrative UR will be recorded to protect workers from future work activities that would cause an exposure exceeding the dose limit of $25 \mathrm{mrem} / \mathrm{yr}$. The administrative UR will be controlled in the same manner as the FFACO URs but will not require postings or inspections. Any proposed activity within the UR area that would change the current land use scenario to a more intensive use of the site would require NDEP approval. 


\subsection{Recommendation}

The U.S. Department of Energy, National Nuclear Security Administration Nevada Site Office (NNSA/NSO) requests that the NDEP issue a Notice of Completion for CAU 367 and approve the promotion of CAU 367 from Appendix III to Appendix IV of the FFACO. 


\subsection{References}

AEC, see Atomic Energy Commission.

Atomic Energy Commission. 1962. Project Sedan-Part 1, Film No. 800030. As accessed at http://www.nv.doe/library/films/film.aspx?ID=17 on 20 September 2009.

BN, see Bechtel Nevada.

Bechtel Nevada. 1999. An Aerial Radiological Survey of the Nevada Test Site, DOE/NV/11718--324. Prepared for the U.S. Department of Energy, Nevada Operations Office. Las Vegas, NV: Remote Sensing Laboratory.

CFR, see Code of Federal Regulations.

Code of Federal Regulations. 2010. Title 10 CFR, Part 835, “Occupational Radiation Protection.” Washington, DC: U.S. Government Printing Office.

DOE, see U.S. Department of Energy.

DOE/NV, see U.S. Department of Energy, Nevada Operations Office.

FFACO, see Federal Facility Agreement and Consent Order.

Federal Facility Agreement and Consent Order. 1996 (as amended March 2010). Agreed to by the State of Nevada; U.S. Department of Energy, Environmental Management; U.S. Department of Defense; and U.S. Department of Energy, Legacy Management.

NAC, see Nevada Administrative Code.

N-I GIS, see Navarro-Intera Geographic Information Systems.

NNSA/NSO, see U.S. Department of Energy, National Nuclear Security Administration Nevada Site Office.

NNSA/NV, see U.S. Department of Energy, National Nuclear Security Administration Nevada Operations Office.

Navarro-Intera Geographic Information Systems. 2011. ESRI ArcGIS Software.

Nevada Administrative Code. 2008. NAC 445A.226 et seq., “Action Levels for Contaminated Sites.” Carson City, NV. As accessed at http://www.leg.state.nv.us/nac/NAC-445A.html on 8 April 2011. 
U.S. Department of Energy. 1990. Compliance Assessment of the Nevada Test Site, DOE/EH-0115. Washington, DC: U.S. Department of Energy, Environment, Safety, and Health.

U.S. Department of Energy, National Nuclear Security Administration Nevada Operations Office. 2002. Industrial Sites Quality Assurance Project Plan, Nevada Test Site, Nevada, Rev. 3, DOE/NV--372. Las Vegas, NV.

U.S. Department of Energy, National Nuclear Security Administration Nevada Site Office. 2004. Mud Pit Risk-Based Closure Strategy Report, Nevada Test Site, Nevada, Rev. 0, DOE/NV--991. Las Vegas, NV.

U.S. Department of Energy, National Nuclear Security Administration Nevada Site Office. 2006. Industrial Sites Project Establishment of Final Action Levels, Rev. 0, DOE/NV--1107. Las Vegas, NV.

U.S. Department of Energy, National Nuclear Security Administration Nevada Site Office. 2009. Corrective Action Investigation Plan for Corrective Action Unit 367: Area 10 Sedan, Ess and Uncle Unit Craters, Nevada Test Site, Nevada, Rev. 0, DOE/NV--1359. Las Vegas, NV.

U.S. Department of Energy, National Nuclear Security Administration Nevada Site Office. 2010. An Aerial Radiological Survey of the Nevada Test Site-Area 10, Corrective Action Unit 367, DOE/NV/25946--956. Prepared by C. Lyons for National Security Technologies, LLC. Las Vegas, NV: Remote Sensing Laboratory.

U.S. Department of Energy, Nevada Operations Office. 2000a. Nevada Test Site Contaminated Land Areas Report, Volume I, DOE/NV/11718--481-VOL 1. Prepared by Bechtel Nevada. Las Vegas, NV.

U.S. Department of Energy, Nevada Operations Office. 2000b. United States Nuclear Tests, July 1945 through September 1992, DOE/NV--209-REV 15. Las Vegas, NV.

Yu, C., A.J. Zielen, J.-J. Cheng, D.J. LePoire, E. Gnanapragasam, S. Kamboj, J. Arnish, A. Wallo III, W.A. Williams, and H. Peterson. 2001. User's Manual for RESRAD Version 6, ANL/EAD-4. Argonne, IL: Argonne National Laboratory, Environmental Assessment Division. (Version 6.5 released in October 2009.) 


\section{Appendix A}

\section{Corrective Action Investigation Results}


This appendix describes the CAI activities and presents analytical results for CAU 367. Corrective Action Unit 367 consists of four CASs located in Area 10 of the NNSS (formerly the Nevada Test Site):

- 10-09-03, Mud Pit

- 10-45-01, U-10h Crater (Sedan)

- 10-45-02, Ess Crater Site

- 10-45-03, Uncle Crater Site

The four CASs are located within 970 meters $(\mathrm{m})$ (0.6 mi) of each other (Figure A.1-1). The crater CASs, 10-45-01, 10-45-02, and 10-45-03, consist of the release of radionuclides to surrounding soil from the Sedan, Ess, and Uncle tests, respectively. These three CASs are collectively referred to as the "crater CASs" throughout this document. The Sedan test was detonated in 1962; the Ess test in 1955; and the Uncle test in 1951 (DOE/NV, 2000). Potential contaminants at these sites include fission products, unfissioned nuclear fuel, and neutron-activated soil and debris resulting from the three tests. Each of the three test devices was detonated underground and resulted in the ejection of soil and rock to form a surface crater. Corrective Action Site 10-09-03 consists of two mud pits identified at CAU 367. One was identified in the CAU 367 CAIP (NNSA/NSO, 2009) and is located at the bottom of the Ess crater. This mud pit consists of drilling mud likely associated with post-test drilling (DOE, 1990). The second mud pit was identified during the CAU 367 CAI and is located adjacent to the U-10ax crater southeast of the Ess crater. Additional information regarding the history of each site and the scope of the investigation is presented in the CAU 367 CAIP.

Based on the proximity of the craters, the impact of the Sedan test on the fallout deposited from the two earlier tests, and aerial radiological surveys, the CAU 367 investigation was designed to study the releases from the three crater CASs as one combined primary release. The mud pits at CAS 10-09-03 are non-test releases (herein referred to as "other releases") and are discussed independent of the three crater CASs. 


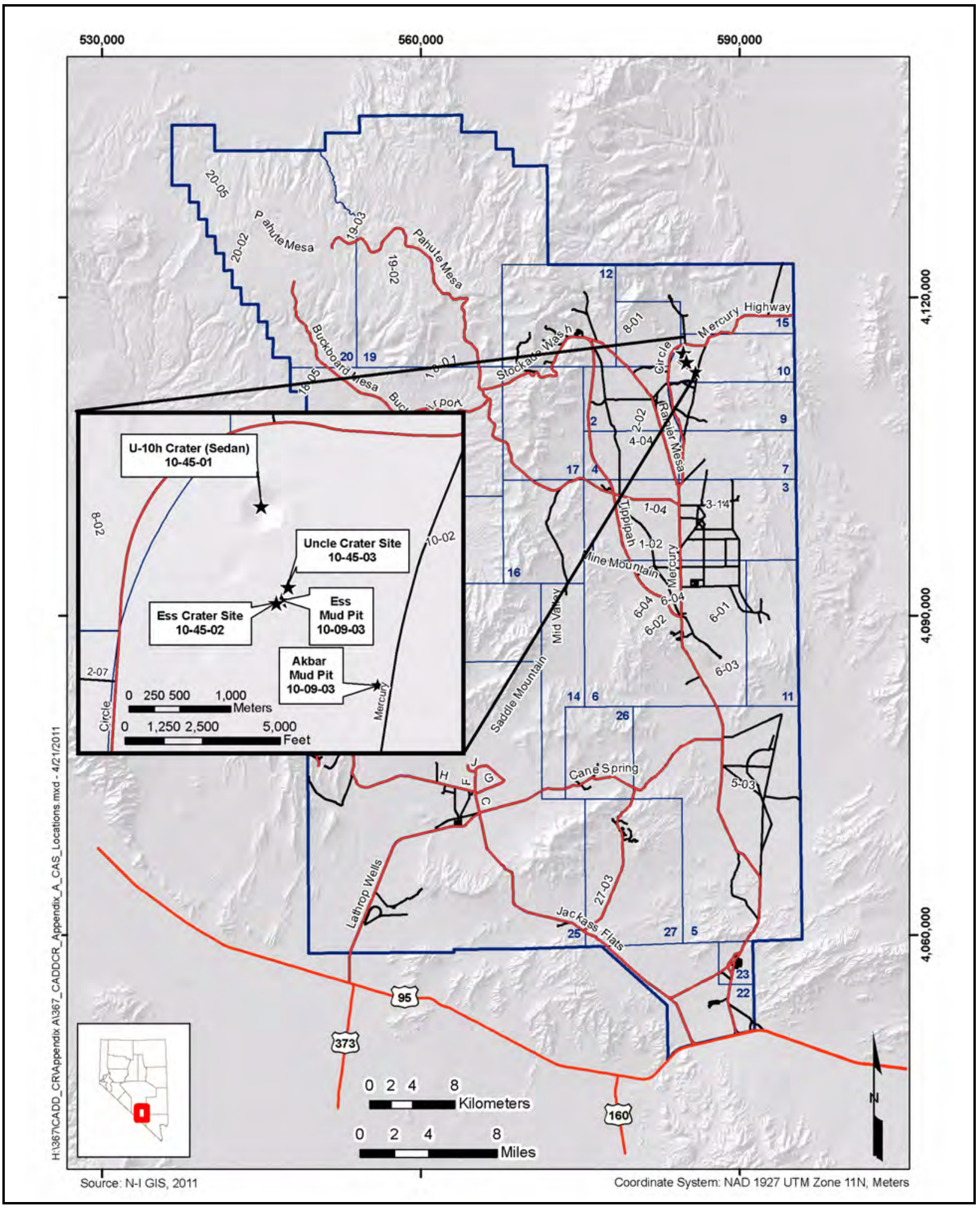

Figure A.1-1 CAU 367, CAS Location Map 


\section{A.1.1 Project Objectives}

The objective of the investigation was to collect sufficient data in order to resolve the following project-specific DQOs:

- Determine whether COCs are present in the soils associated with CAU 367.

- Determine the nature and extent of identified COCs.

- Ensure adequate data are collected to evaluate CAAs and meet the requirements of the FFACO.

This objective was achieved by defining the nature and extent of COCs and by evaluating, selecting, and implementing acceptable CAAs.

For radiological contamination, a COC is defined as the presence of radionuclides that jointly present a dose to a receptor exceeding the FAL of $25 \mathrm{mrem} / \mathrm{yr}$. For other types of contamination, a COC is defined as a contaminant present at a concentration exceeding its corresponding FAL concentration (see Section A.2.5).

\section{A.1.2 Contents}

This appendix describes the investigation and presents the results. The contents of this appendix are as follows:

- Section A.1.0 describes the investigation background, objectives, and contents.

- Section A.2.0 provides an investigation overview.

- Section A.3.0 provides information regarding field activities, sampling methods, and laboratory analytical results from investigation sampling associated with the three crater CASs (10-45-01, 10-45-02, and 10-45-03).

- Section A.4.0 provides information regarding field activities, sampling methods, and laboratory analytical results from investigation sampling at other releases, including CAS 10-09-03.

- Section A.5.0 summarizes waste management activities.

- Section A.6.0 discusses the QA and QC processes followed and the results of QA/QC activities. 
- Section A.7.0 provides a summary of the investigation results.

- Section A.8.0 lists the cited references.

The complete field documentation and laboratory data, including field activity daily logs, sample collection logs, analysis request/chain-of-custody forms, soil sample descriptions, laboratory certificates of analyses, and analytical results, are retained in project files as hard copy files or electronic media. 
Field investigation and sampling activities for the CAU 367 CAI were conducted from February 2010 through March 2011 and included the following activities:

- $\quad$ Performed visual surveys to identify PSM.

- $\quad$ Staged TLDs at soil sample plots, background locations, and biased sample locations.

- Conducted ground-based radiological surveys.

- Established sample plots and composite sample aliquot locations.

- Collected surface and subsurface soil samples.

- Submitted soil samples for offsite laboratory analysis.

- Collected GPS coordinates of sample locations and TLD locations.

- Collected and submitted TLDs for analysis.

The investigation and sampling program adhered to the requirements set forth in the CAU 367 CAIP (NNSA/NSO, 2009). Quality control samples (e.g., duplicate samples) were collected as required by the Industrial Sites QAPP (NNSA/NV, 2002a) and the CAU 367 CAIP.

To facilitate site investigation and the evaluation of DQO decisions for different CSM components, the releases at CAU 367 were classified into two categories:

- Primary releases (referred to as “Test Releases” in the CAIP) - This release category is specific to the atmospheric deposition of radionuclide contamination onto the soil surface (i.e., fallout) that has not been displaced through excavation or migration. Primary releases were investigated via a combination of external dose assessment using TLDs and internal dose assessment through the collection and laboratory analysis of soil samples. Due to the potential layering of contamination from the Uncle, Ess, and Sedan tests, shallow subsurface radionuclide contamination is also considered part of the primary release.

- Other releases (referred to as “Non-test Releases” in the CAIP)—This release category includes releases not considered primary releases and may include any of the following:

- Radionuclide contaminants that were initially deposited onto the soil surface (as in the primary release category) but have subsequently been displaced through excavation or migration.

- Radionuclides deposited under mechanisms other than atmospheric deposition to include the injection of radionuclides into native material from the nuclear detonation (prompt injection) and the deposition of ejecta piles around a crater. 
- Any other chemical or radiological contamination discovered during the investigation that is not a part of a previously identified release.

The primary release was investigated by conducting ground-based radiological surveys, employing TLDs, and collecting soil samples. The selection of soil sample locations was based on site conditions and the strategy developed during the DQO process as presented in the CAIP (NNSA/NSO, 2009). The field investigation was completed as specified in the CAIP with the exception of minor deviations described in Sections A.3.0 and A.4.0. Internal dose to a receptor was estimated based on analytical results from the composite soil samples, and external dose was determined from the staged TLDs.

The Ess mud pit at CAS 10-09-03 and other releases were sampled using a judgmental strategy based on visual and radiological biasing factors. The other mud pit at CAS 10-09-03, the Akbar mud pit, was not sampled.

The general investigation and evaluation methodologies are discussed in Sections A.2.1 through A.2.5.

\section{A.2.1 Sample Locations}

Judgmental sample locations for investigation of the primary release were established based on the four-vector sampling approach outlined in the CAIP (NNSA/NSO, 2009). The four vectors, herein referred to as the east, south, northwest, and northeast vectors, and the sample locations on each vector, were established based primarily on the interpretation of the 1994 and 2009 aerial radiological survey data (BN,1999; NNSA/NSO, 2010a) and ground-based radiological surveys. Radionuclide Inventory and Distribution Program (RIDP) data (McArthur and Mead, 1987; Gray et al., 2007) and site conditions also were considered. The four vectors radiate from the center of the Sedan contamination plume and extend outward approximately 1,000 m (Figure A.2-1). Samples were collected from each sample plot based on a probabilistic selection of composite sample aliquot locations within each plot. One TLD was staged at the center of each of the sample plots. In addition, four other TLDs were placed along each vector and at other biased locations at CAU 367. Sample locations for the investigation of other releases, including the Ess mud pit (CAS 10-09-03), were established based on visual and radiological biasing factors. 
The environmental sample plot locations and TLD locations for the three crater CASs are shown in Figure A.2-1. Some sample locations were modified slightly from planned positions due to field conditions and observations. The locations of the sample plots, TLDs, and other releases were recorded with a GPS instrument. Appendix G presents these data in a tabular format.

The CAU 367 primary release and other release sampling locations were accessible and remained within anticipated spatial boundaries.

\section{A.2.2 Investigation Activities}

The investigation activities conducted at CAU 367 were consistent with the field investigation activities specified in the CAIP (NNSA/NSO, 2009). The investigation strategy provided the necessary information to establish the nature and extent of contamination associated with each CAS. This section describes the general approach to investigation at CAU 367; specific investigation activities are discussed in Sections A.3.0 and A.4.0.

\section{A.2.2.1 Visual Surveys}

Visual surveys at CAU 367 were conducted in the vicinity of all sample plots, TLD locations, and other release sampling locations, including an area along the shoulder of Circle Road northwest of the Sedan crater and the mud pits at CAS 10-09-03. In addition, a comprehensive, site-wide visual survey was completed over an area of approximately 2,200 acres at CAU 367.

The objective of the visual surveys was to identify indications of other releases (e.g., soil staining) and PSM that may release contaminants in the future. The PSM items within the defined scope of CAU 367 are considered other releases and are discussed in Section A.4.0. Those items inventoried but not identified as PSM are not considered to be within the scope of the CAU 367 investigation and will be addressed as a BMP, where appropriate.

\section{A.2.2.2 Radiological Surveys}

Aerial and ground-based radiological surveys were conducted in support of the CAU 367 investigation. 


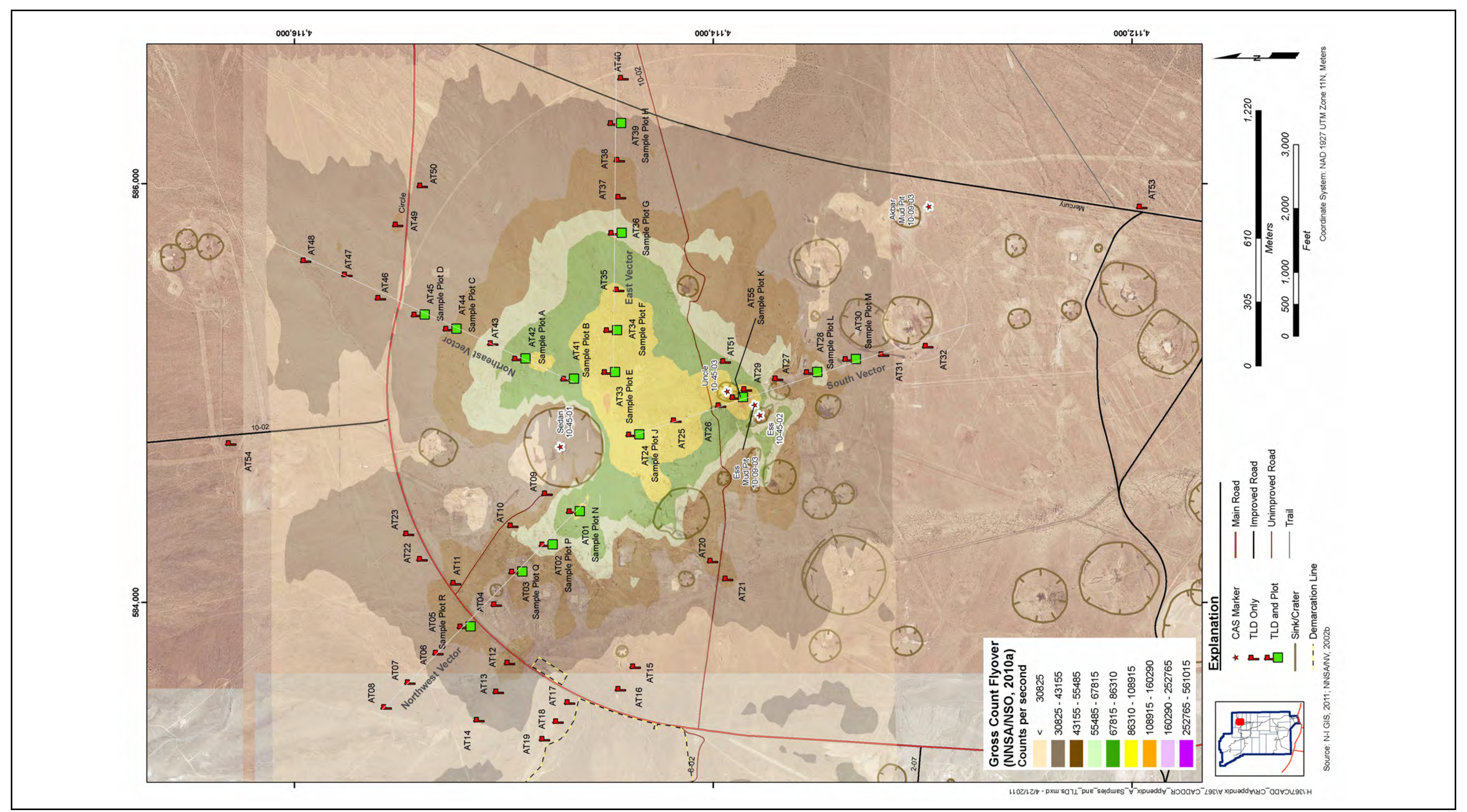


The aerial radiological survey available at the time the CAU 367 CAIP was written was completed in 1994 (BN, 1999). This survey was conducted at an altitude of 200 feet (ft) with 500-ft flight-line spacing. The results from this survey were used to determine the basic distribution of radionuclides at CAU 367 and proposed TLD and sample plot locations. In October 2009, another aerial radiological survey of CAU 367 was completed at an altitude of $50 \mathrm{ft}$ with 100-ft flight-line spacing (NNSA/NSO, 2010a). The results of the 2009 survey were used to adjust the orientation of the four sampling vectors, guide the placement of TLDs, and select areas for ground-based radiological surveys.

Ground-based radiological surveys using a PRM-470 instrument coupled with a GPS receiver and datalogger were performed to confirm the general spatial distribution of the contaminant plume as identified in the aerial surveys and to select the locations of sample plots and biased sample locations. Radiological surveys were conducted along four corridors that spanned the length of each vector (approximately 1,000 m) and approximately $25 \mathrm{~m}$ to either side of each vector. Additional detailed surveys were conducted along the south vector in the area around the Uncle and Ess craters and at the Circle Road investigation area northwest of the Sedan crater.

Ground-based radiological surveys for the detection of americium (Am)-241 were conducted using a field instrument for the detection of low-energy radiation (FIDLER) coupled with a GPS receiver and datalogger. Because Am-241 is more easily detected in the field than plutonium (Pu), the FIDLER survey results are typically used as an indicator to estimate the distribution and relative concentration of plutonium in the surveyed area. The FIDLER surveys were completed along the east vector and portions of the northeast and south vectors; however, the survey data were not representative of plutonium concentrations and were not used in the evaluation of CAU 367 releases (see Section A.3.1.2.3).

\section{A.2.2.3 Field Screening}

Field screening was utilized at CAU 367 to evaluate the presence of buried contamination around the Uncle and Ess crater sites and to aid in the selection of biased samples for laboratory analyses. Field screening was limited to radiological parameters and was conducted using an NE Electra instrument. 
As part of the primary release investigation, screening borings were installed next to select sample plots to determine the presence of a buried layer(s) of contamination (see Section A.3.2.1.1). At each boring, soil was removed and screened for radioactivity in 5-centimeter (cm)-depth increments to a total depth of $30 \mathrm{~cm}$ below ground surface (bgs). These field-screening results were used to determine whether a subsurface contamination layer(s) could be distinguished from surface contamination. Buried contamination was considered to be present only if the depth interval reading exceeded the field-screening limit (FSL) and there was a greater than 20 percent difference between the depth interval reading and the surface soil reading. Based on the results of the screening borings, one sample plot was selected for the collection of subsurface soil samples. Composite shallow subsurface soil samples were collected from this sample plot as described in Section A.2.2.4 below. However, prior to compositing, each sample aliquot was field screened for radioactivity. The depth interval with the highest reading from each aliquot was composited into a sample to be sent for offsite laboratory analyses.

The same general field-screening process was used during collection of grab samples at the Circle Road sample locations (see Section A.4.2.1). At these sample locations, a 30-cm soil boring was collected and field screened for radioactivity in 5-cm-depth increments. The single depth interval with the highest reading, based on the radiological screening criteria above, was selected for laboratory analyses.

\section{A.2.2.4 Soil Sampling}

Soil sampling at CAU 367 consisted of the collection of surface and subsurface soil samples. For the purpose of this investigation, surface soils are defined as the top $5 \mathrm{~cm}$ of soil, shallow subsurface soils are defined as the 5- to 30 -cm interval, and subsurface soils are defined as greater than $30 \mathrm{~cm}$ in depth.

Composite surface soil samples were collected at each sample plot. Each sample consisted of 9 randomly located aliquots, resulting in a total of 36 randomly located aliquots collected from each 100-square-meter $\left(\mathrm{m}^{2}\right)$ plot. The aliquot locations were identified using a predetermined random-start, triangular grid pattern. The random sample location coordinates were generated in the Visual Sample Plan (VSP) software (PNNL, 2007). Sample aliquots were collected using a "vertical-slice cylinder and bottom-trowel” method, which allowed capture of a 5-cm-thick 
cylindrical-shaped column of soil. All nine aliquots were combined atop a sieve (\#4 mesh) fitted into a bottom pan with a plastic liner. The sample was slowly sieved to minimize dust hazards, and oversized material left atop the sieve was returned to the original sample location. The sample was then transferred to a metal can and shaken using a paint shaker for three minutes to homogenize the soil. The basic method for collection of composite shallow subsurface soil samples at a sample plot was the same as for surface samples, but included a field-screening step for each sample aliquot described in Section A.2.2.3. The subsurface sampling methodology was also utilized in the collection of the Circle Road samples, except that these samples were grab samples collected from a single depth interval, which was selected based on field-screening results as described in Section A.2.2.3.

Surface and shallow subsurface soil samples at the Ess mud pit and the PSM locations were collected using hand-sampling instruments. A shovel or trowel was used to dig to the depth of interest, to collect a discrete volume of soil (grab sample), which was then placed into a sample container.

\section{A.2.2.5 Internal Dose Estimates}

The potential internal dose that a receptor would receive at each soil sample location was estimated using the radionuclide analytical results from soil samples and the corresponding RRMGs (referred to as the derived concentration guidelines in the CAIP [NNSA/NSO, 2009]) (see Attachment C-1). The internal dose RRMG concentration for a particular radionuclide is the concentration in surface soil that would cause an internal dose to a receptor of 25 mrem/yr (under the appropriate exposure scenario) independent of any other radionuclide (i.e., assuming that no other radionuclides contribute dose). The internal dose RRMG for each detected radionuclide (in picocuries per gram [pCi/g] of soil) was derived using the RESRAD computer code (Yu et al., 2001) under the appropriate exposure scenario.

The total internal dose corresponding to each sample was calculated by adding the dose contribution from each radionuclide. To estimate internal dose for each soil sample, the radionuclide-specific analytical result was divided by its corresponding internal RRMG to yield a fraction of the 25-mrem/yr dose. The fractions for all radionuclides detected in a soil sample were summed to yield a sum of the fractions for that sample. The total fraction was then multiplied by 25 to yield an internal dose estimate (in millirem per year) at that sample location (i.e., committed effective 
dose). For the primary release sample plots, a 95 percent UCL of the mean was then calculated for the internal dose in a sample plot using the results of all soil samples collected in that plot (see Appendix C).

With one exception, all internal dose estimations were calculated using surface soil sample results (0 to $5 \mathrm{~cm}$ bgs). Based on the potential for buried contamination near the Uncle and Ess craters due to overlapping atmospheric deposition from the three tests, shallow subsurface soil samples (5 to $30 \mathrm{~cm}$ bgs) were collected at one sample plot (see Section A.3.2.1.1). In accordance with the CAIP (NNSA/NSO, 2009), the samples with the highest internal dose (surface or subsurface) at this sample plot would be used to estimate internal dose at that location.

As part of the internal dose assessment, inferred values for plutonium (Pu-238 and Pu-239/240), in units of picocuries per gram of soil, were calculated. Samples for which inferred plutonium values were calculated were limited to those analyzed by both gamma spectroscopy and isotopic analytical methods. The use of inferred plutonium values is designed to minimize the effect of sampling bias on the evaluation. Sampling bias may occur when the contents of an individual soil sample are not representative of the true average concentration of a contaminant in the area that was sampled. This potential bias is inherent in the isotopic analytical method used to measure plutonium and is not due to an error in the field-sampling method. Plutonium can only be adequately quantified via alpha spectroscopy (isotopic analyses). By nature of the analytical process of alpha spectroscopy, only very small volumes of soil can be analyzed (e.g., 1 to 5 grams). Plutonium contamination in soils at a detonation site or a safety experiment site generally consists of small particles with relative high specific activity. Because of the high specific activity and the low RRMGs for plutonium, the collection of a few plutonium particles in a single small soil sample could result in a falsely high or low internal dose estimate.

To address this issue, the investigation strategy included the collection and analysis of relatively large volumes (e.g., 3/4 gallon) of composited soil. The large volume is analyzed via gamma spectroscopy, which quantifies the amount of Am-241 that is present (note that gamma spectroscopy cannot adequately quantify the amounts of Pu-238 and Pu-239/240 that are present). A small aliquot of the large volume is then analyzed by alpha spectroscopy to quantify the ratios of Am-241 to $\mathrm{Pu}-238$ and the ratios of $\mathrm{Pu}-239 / 240$ to Am-241. Theoretically, these ratios are constant and should 
be consistent for all samples from the same release. Once the ratios are established, the amount of Am-241 present in the large volume soil sample can be used to infer the amounts of Pu-238 and $\mathrm{Pu}-239 / 240$ that are present in the large volume sample, reducing the potential effects of sampling bias.

For TLD locations where soil samples were not collected, the internal dose was estimated using the external dose measurement from the TLD and the ratio of internal to external dose from the plot with the maximum internal dose. The internal dose for each of these locations was calculated by multiplying this ratio (from the plot with the maximum internal dose) by the external dose value specific to each location.

\section{A.2.2.6 External Dose Measurements}

Thermoluminescent dosimeters (Panasonic UD-814) were emplaced at CAU 367 with the objective of collecting in situ measurements to determine the external radiological dose. The TLDs were placed in background areas (i.e., beyond the influence of CAS releases), at the approximate center of each sample plot, and at other biased locations. Each TLD was placed at a height of $1 \mathrm{~m}$ above the ground surface, which is consistent with TLD placement in the NNSS routine environmental monitoring program. Once retrieved from the field locations, the TLDs were analyzed by automated TLD readers that are calibrated and maintained by the NNSS management and operating contractor. Details of the environmental monitoring TLD program and TLD QC are presented in Section A.6.0.

The TLDs used at CAU 367 contain four individual elements. Each of these elements is considered a separate, independent measurement of external dose. External dose at each TLD location is determined using the readings from TLD elements 2, 3, and 4. Element 1 is designed to measure dose to the skin and is not relevant to the determination of the external dose for the purpose of this investigation. Measurements from control and background TLDs were subtracted from the raw TLD element data. The control, or rack, background TLDs measured the amount of radiation the TLDs were exposed to prior to being deployed in the field. The rack background TLDs were staged at Building 23-153 in the same area where the environmental TLDs were stored prior to emplacement at CAU 367. A total of eight TLDs were placed at locations believed to be beyond the influence of CAU 367 releases. These TLDs were intended to measure a dose representative of background conditions. Based on isopleth maps generated from the 2009 aerial radiation surveys 
(NNSA/NSO, 2010a), three of the TLDs (AT53, AT54, and AT57) were removed from consideration as background TLDs because they may have been placed within the contamination plume. Due to the large area affected by the release, the dose from the remaining background TLDs varied significantly. To aid in the determination of the proper background dose to use in TED calculation, a background isopleth map generated from the 1994 aerial radiation survey was used to verify that background TLDs represent the background dose estimated at CAU 367 TLD locations (Hendricks, 2011). The TLDs located at AT56 and AT59 produced doses that were anomalously low when compared to the other background TLD results. The TLD at location AT56 is located the farthest distance from CAU 367 and is in an area with background values that are not representative of the background values in the area of CAU 367. The TLD location AT59 is located in the foothills of a mountain range southeast of CAU 367 (Figure A.2-2) in an area shown to have much lower natural background values than the CAU 367 area based on the background isopleth map. Therefore, it was determined that these TLD locations would also be excluded from background dose determination. The background dose at CAU 367 was determined to be the average of the TLD results from locations AT52, AT58, and AT60 (30.85 mrem/IA-yr).

After subtracting control and background TLD readings, the TLD value was then divided by the number of hours the TLD was exposed to site contamination, resulting in a net hourly dose rate. The hourly dose rate was then multiplied by the number of hours per year that a site worker would be present at the site (i.e., the annual exposure duration) to establish the maximum potential annual external dose a site worker could receive. The appropriate annual exposure duration in hours is based on the exposure scenario. The resulting net values were then used to calculate the average TED and the 95 percent UCL of the average TED for each TLD location. The TLD results are discussed in Section A.3.2.2.

\section{A.2.3 Total Effective Dose}

The TED represents the sum of the internal dose (calculated from soil sample results) and the external dose (calculated from TLD measurements) for each sample location. The average TED calculated from sample results is an estimate of the true (unknown) TED. It is uncertain how well the average TED represents the true TED. If an average TED were directly compared to the FAL, any significant difference between the true TED and the sample TED could lead to decision errors. To reduce the 


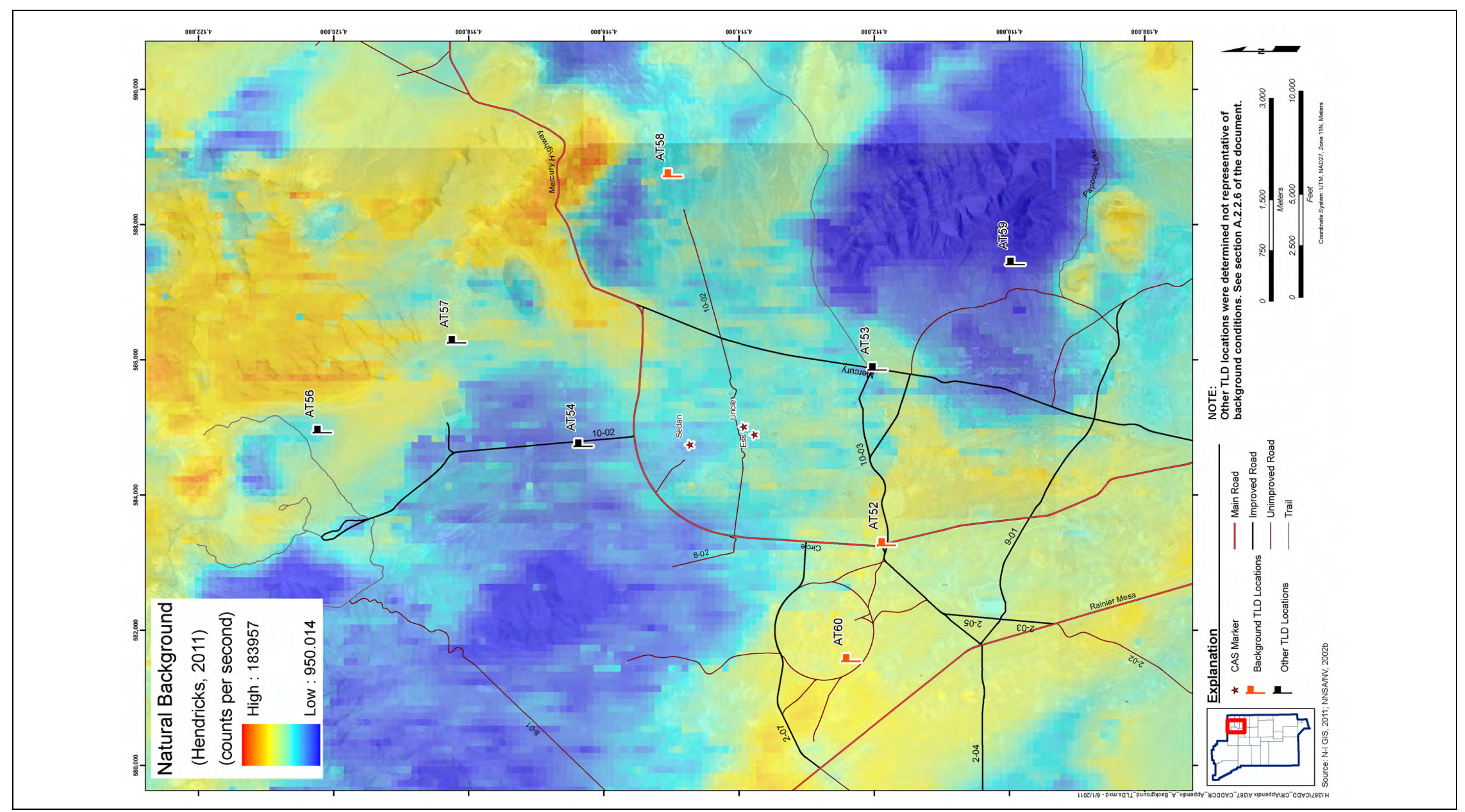


probability of a false negative decision error for probabilistic sampling, a conservative estimate of the true TED is used to compare to the FAL. This conservative estimate of the true TED was calculated as the 95 percent UCL of the average TED. By definition, there will be a 95 percent probability that the true TED is less than the 95 percent UCL of the calculated average TED.

The probabilistic sampling design as described in the CAIP conservatively prescribes using the 95 percent UCL of the TED to estimate dose at each sample plot. The 95 percent UCL of the average TED at each sample location was calculated as the sum of the 95 percent UCLs of the internal and external doses.

At all TLD locations, the 95 percent UCL of the TLD element reading was used as the external dose input to the TED calculation. Because not every TLD placed at CAU 367 was associated with a sample plot, the input parameters used to calculate TED at sample plot locations were different from those at TLD-only locations. At locations with both a TLD and a sample plot, the 95 percent UCL internal dose from the individual sample plot data was used as the internal dose input. At TLD-only locations, the 95 percent UCL internal dose was calculated using the ratio of the 95 percent UCL internal dose to the 95 percent UCL external dose from the sample plot location of the maximum internal dose (sample plot G) (see Table A.3-5). That is, at TLD-only locations, the 95 percent UCL external dose value (from the TLD) was multiplied by the ratio of internal to external dose from sample plot G. The resulting value was used as the internal dose input for the TED calculation. No TLDs were staged at grab sample locations (CAS 10-09-03, Circle Road, and PSM locations). At these locations, the TED was calculated using RRMGs established based on total (internal and external) dose. The 95 percent UCL internal dose was not calculated for grab sample data because there were not a sufficient number of samples collected at each location to calculate the 95 percent UCL.

\section{A.2.4 Laboratory Analytical Information}

Radiological and chemical analyses of the collected soil samples were performed by the ALS Laboratory Group in Fort Collins, Colorado. The analytical suites and laboratory analytical methods used to analyze investigation samples are listed in Table A.2-1. Analytical results are reported in this appendix if they were detected above the minimum detectable concentrations (MDCs). The complete laboratory data packages are available in the project files. 
Table A.2-1

Laboratory Analyses and Methods, CAU 367 Investigation Samples $^{\mathrm{a}}$

\begin{tabular}{|c|c|}
\hline Analysis & Analytical Method ${ }^{b}$ \\
\hline \multicolumn{2}{|c|}{ Radiological } \\
\hline Isotopic U & Aqueous/Non-aqueous - DOE EML HASL-300 U-02-RC \\
\hline Isotopic Pu & $\begin{array}{c}\text { Aqueous - DOE EML HASL-300' } \mathrm{Pu}-10-\mathrm{RC} \\
\text { Non-aqueous - DOE EML HASL-300' } \mathrm{Pu}-02-\mathrm{RC}\end{array}$ \\
\hline Isotopic Am & $\begin{array}{c}\text { Aqueous - DOE EML HASL-300' Am-03-RC } \\
\text { Non-aqueous - DOE EML HASL-300` Am-01-RC }\end{array}$ \\
\hline Gamma Spectroscopy & $\begin{array}{c}\text { Aqueous - EPA 901.1 } \\
\text { Non-aqueous - DOE EML HASL-300 } \mathrm{Ga-Rb-R}\end{array}$ \\
\hline Sr-90 & $\begin{array}{c}\text { Aqueous - EPA } 905.0^{d} \\
\text { Non-aqueous - DOE EML HASL-300 } \mathrm{Cr}-02-\mathrm{RC}\end{array}$ \\
\hline \multicolumn{2}{|c|}{ Chemical } \\
\hline VOCs & EPA SW-846 8260 \\
\hline SVOCs & EPA SW-846 8270 \\
\hline
\end{tabular}

anvestigation samples include both environmental and associated QC samples.

${ }^{\mathrm{b}}$ The most current analytical method accepted by EPA, DOE, ASTM, NIOSH, or equivalent was used, including approved Laboratory Standard Operating Procedures (NNES, 2009).

${ }^{\mathrm{c}}$ The Procedures Manual of the Environmental Measurements Laboratory (DOE, 1997).

${ }^{\mathrm{d}}$ Prescribed Procedures for Measurement of Radioactivity in Drinking Water (EPA, 1980).

${ }^{\mathrm{e}}$ Test Methods for Evaluating Solid Waste, Physical/Chemical Methods (EPA, 2011).

ASTM = ASTM International

$E M L=$ Environmental Measurements Laboratory

EPA = U.S. Environmental Protection Agency

HASL $=$ Health and Safety Laboratory
$\mathrm{NIOSH}=$ National Institute for Occupational Safety and Health

$\mathrm{Sr}=$ Strontium

SVOC $=$ Semivolatile organic compound

$\mathrm{U}=$ Uranium

VOC $=$ Volatile organic compound

Validated analytical data for CAU 367 investigation samples have been compiled and evaluated to determine the presence of COCs and to define the extent of contamination, if present. The validated results of the radiochemical analyses were evaluated for all radionuclides that contribute to dose (see Appendix C). The analytical results for each CAS and other releases are presented in Sections A.3.0 and A.4.0.

\section{A.2.5 Comparison to Action Levels}

The radiological PALs and FALs are based on an annual dose limit of $25 \mathrm{mrem} / \mathrm{yr}$. This dose limit is specific to the annual dose a receptor could potentially receive from a CAU 367 release. As such, it is dependent upon the cumulative annual hours of exposure to site contamination. The PALs were 
established in the CAIP based on a dose limit of 25 mrem/yr over an annual exposure time of 2,250 hours (i.e., the Industrial Area exposure scenario that a site worker would be exposed to site contamination for $10 \mathrm{hr} /$ day for 225 day/yr). The FALs were established in Appendix C based on a dose limit of 25 mrem/yr over an annual exposure time of 336 hours (i.e., the Remote Work Area exposure scenario in which a site worker is exposed to site contamination for $8 \mathrm{hr} / \mathrm{day}$ for 42 day/yr).

The investigation results for the primary release and other releases are presented in Sections A.3.0 and A.4.0. Radiological results are reported as doses that are compared to the dose-based FAL as established in Appendix C. Chemical results are reported as individual concentrations that are compared to the individual chemical action levels as established in Appendix C.

A COC is defined as any contaminant present in environmental media exceeding a FAL. A COC may also be defined as a contaminant that, in combination with other like contaminants, is determined to jointly pose an unacceptable risk based on a multiple constituent analysis (NNSA/NSO, 2006b). If COCs are present, a corrective action must be considered for the CAS.

A corrective action may also be required if a waste present within a CAS contains contaminants that, if released, could cause the surrounding environmental media to contain a COC. Such a waste would be considered PSM. To evaluate wastes for the potential to result in the introduction of a COC to the surrounding environmental media, the conservative assumption was made that any physical waste containment (e.g., drum) would fail at some point and release the contaminants to the surrounding media. The following was used as the criteria for determining whether a waste is PSM:

- A waste, regardless of concentration or configuration, may be assumed to be PSM and handled under a corrective action.

- Based on process knowledge and/or professional judgment, some waste may be assumed not to be PSM if it is clear that it could not result in soil contamination exceeding a FAL.

- If assumptions about the waste cannot be made, then the waste material will be sampled and the results will be compared to FALs based on the following criteria:

- For nonliquid wastes, the concentration of any chemical contaminant in soil (following degradation of the waste and release of contaminants into soil) would be equal to the mass of the contaminant in the waste divided by the mass of the waste. If the resulting soil concentration exceeds the FAL, then the waste would be considered PSM. 
- For nonliquid wastes, the dose resulting from radioactive contaminants in soil (following degradation of the waste and release of contaminants into soil) would be calculated using the activity of the contaminant in the waste divided by the mass of the waste (for each radioactive contaminant) and calculating the combined resulting dose using the RESRAD code (Murphy, 2004). If the resulting soil concentration exceeds the FAL, then the waste would be considered PSM.

- For liquid wastes, the resulting concentration of contaminants in the surrounding soil will be calculated based on the concentration of contaminants in the waste and the liquid-holding capacity of the soil. If the resulting soil concentration exceeds the FAL, then the liquid waste would be considered PSM. 


\section{A.3.0 Primary Release}

The three crater CASs, 10-45-01 (Sedan crater), 10-45-02 (Ess crater), and 10-45-03 (Uncle crater) were investigated as one primary release, rather than three individual releases. This investigative approach was selected based on historical information suggesting that the area of the Sedan release encompassed the Uncle and Ess test releases. Historical video footage of the Sedan test shows the base surge scouring and lifting surface soil out to a diameter of $5 \mathrm{mi}$ from Sedan ground zero (AEC, 1962). Presumably, airborne soil and rock from the Sedan test were deposited on top of the existing ejecta from the Uncle and Ess tests. In addition, the two aerial radiological surveys conducted in 1994 and 2009 (BN, 1999; NNSA/NSO, 2010a) suggest a single, large contamination plume originating from the Sedan site. Potential contaminants at these sites include fission products, unfissioned nuclear fuel, and neutron-activated soil and debris resulting from the three tests.

\section{A.3.1 Corrective Action Investigation Activities}

A total of 72 environmental soil samples (68 surface, 4 subsurface) were collected from 16 sample plots located along 4 sample vectors (Figure A.2-1). The sample numbers, locations, and types are listed in Table A.3-1. All samples collected from the sample plots were analyzed for gamma spectroscopy, Sr-90, and isotopic U, Pu, and Am.

A total of 68 TLD samples (65 environmental and 3 background) were collected during investigation activities from the area around the three crater CASs to measure external dose. The TLD identification numbers, locations, and types are listed in Table A.3-2.

The specific CAI activities conducted to satisfy the CAIP requirements (NNSA/NSO, 2009) at these CASs are described in the following sections.

\section{A.3.1.1 Visual Surveys}

Visual surveys were performed to delineate the default contamination boundary at each crater CAS and to identify potential surface migration pathways associated with the primary release. The purpose of the default contamination boundary survey was to identify the extent of the ejecta mounds/fields around each of the three crater CASs. The default contamination boundary at each 
Table A.3-1

Soil Samples Collected at CAU 367

(Page 1 of 3 )

\begin{tabular}{|c|c|c|c|c|}
\hline Sample Plot & $\begin{array}{l}\text { Sample } \\
\text { Number }\end{array}$ & $\begin{array}{c}\text { Depth } \\
\text { (cm bgs) }\end{array}$ & Matrix & Purpose \\
\hline \multirow{4}{*}{ A } & $367 A 01$ & $0-5$ & Soil & Environmental \\
\hline & 367A02 & $0-5$ & Soil & Environmental \\
\hline & $367 A 03$ & $0-5$ & Soil & Environmental \\
\hline & $367 A 04$ & $0-5$ & Soil & Environmental \\
\hline \multirow{4}{*}{ B } & 367B01 & $0-5$ & Soil & Environmental \\
\hline & 367B02 & $0-5$ & Soil & Environmental \\
\hline & 367B03 & $0-5$ & Soil & Environmental \\
\hline & 367B04 & $0-5$ & Soil & Environmental \\
\hline \multirow{4}{*}{ C } & $367 \mathrm{C01}$ & $0-5$ & Soil & Environmental \\
\hline & $367 \mathrm{C} 02$ & $0-5$ & Soil & Environmental \\
\hline & $367 \mathrm{C03}$ & $0-5$ & Soil & Environmental \\
\hline & $367 \mathrm{C0} 4$ & $0-5$ & Soil & Environmental \\
\hline \multirow{4}{*}{ D } & 367D01 & $0-5$ & Soil & Environmental \\
\hline & 367D02 & $0-5$ & Soil & Environmental \\
\hline & 367D03 & $0-5$ & Soil & Environmental \\
\hline & 367D04 & $0-5$ & Soil & Environmental \\
\hline \multirow{5}{*}{$E$} & 367E01 & $0-5$ & Soil & Environmental \\
\hline & 367E02 & $0-5$ & Soil & Environmental \\
\hline & 367E03 & $0-5$ & Soil & Environmental \\
\hline & 367E04 & $0-5$ & Soil & Environmental and Full Lab QC \\
\hline & 367E05 & $0-5$ & Soil & FD of \#367E04 \\
\hline \multirow{4}{*}{$\mathrm{F}$} & 367F01 & $0-5$ & Soil & Environmental \\
\hline & 367F02 & $0-5$ & Soil & Environmental \\
\hline & 367F03 & $0-5$ & Soil & Environmental \\
\hline & 367F04 & $0-5$ & Soil & Environmental \\
\hline \multirow{4}{*}{ G } & $367 \mathrm{G} 01$ & $0-5$ & Soil & Environmental \\
\hline & $367 G 02$ & $0-5$ & Soil & Environmental \\
\hline & 367G03 & $0-5$ & Soil & Environmental \\
\hline & $367 G 04$ & $0-5$ & Soil & Environmental \\
\hline
\end{tabular}


Table A.3-1

Soil Samples Collected at CAU 367

(Page 2 of 3 )

\begin{tabular}{|c|c|c|c|c|}
\hline Sample Plot & $\begin{array}{l}\text { Sample } \\
\text { Number }\end{array}$ & $\begin{array}{c}\text { Depth } \\
\text { (cm bgs) }\end{array}$ & Matrix & Purpose \\
\hline \multirow{4}{*}{$\mathrm{H}$} & $367 \mathrm{H} 01$ & $0-5$ & Soil & Environmental \\
\hline & $367 \mathrm{H} 02$ & $0-5$ & Soil & Environmental \\
\hline & $367 \mathrm{H} 03$ & $0-5$ & Soil & Environmental \\
\hline & $367 \mathrm{HO4}$ & $0-5$ & Soil & Environmental \\
\hline \multirow{4}{*}{$\mathrm{J}$} & $367 \mathrm{J01}$ & $0-5$ & Soil & Environmental \\
\hline & $367 \mathrm{~J} 02$ & $0-5$ & Soil & Environmental \\
\hline & $367 \mathrm{J03}$ & $0-5$ & Soil & Environmental \\
\hline & $367 \mathrm{~J} 04$ & $0-5$ & Soil & Environmental \\
\hline \multirow{9}{*}{$\mathrm{K}$} & $367 \mathrm{~K} 01$ & $0-5$ & Soil & Environmental \\
\hline & $367 \mathrm{~K} 02$ & $0-5$ & Soil & Environmental \\
\hline & $367 \mathrm{~K} 03$ & $0-5$ & Soil & Environmental \\
\hline & $367 \mathrm{~K} 04$ & $0-5$ & Soil & Environmental and Full Lab QC \\
\hline & $367 \mathrm{~K} 05$ & $0-5$ & Soil & FD of $367 \mathrm{~K} 04$ \\
\hline & $367 \mathrm{~K} 06$ & $5-25^{a}$ & Soil & Environmental \\
\hline & $367 \mathrm{~K} 07$ & $5-25^{a}$ & Soil & Environmental \\
\hline & $367 \mathrm{~K} 08$ & $5-25^{a}$ & Soil & Environmental \\
\hline & $367 \mathrm{~K} 09$ & $5-20^{a}$ & Soil & Environmental \\
\hline \multirow{4}{*}{$\mathrm{L}$} & 367L01 & $0-5$ & Soil & Environmental \\
\hline & 367L02 & $0-5$ & Soil & Environmental \\
\hline & 367L03 & $0-5$ & Soil & Environmental \\
\hline & 367L04 & $0-5$ & Soil & Environmental \\
\hline \multirow{5}{*}{ M } & 367M01 & $0-5$ & Soil & Environmental \\
\hline & 367M02 & $0-5$ & Soil & Environmental \\
\hline & 367M03 & $0-5$ & Soil & Environmental \\
\hline & 367M04 & $0-5$ & Soil & Environmental \\
\hline & 367M05 & $0-5$ & Soil & FD of $367 \mathrm{M} 04$ \\
\hline
\end{tabular}


Table A.3-1

Soil Samples Collected at CAU 367

(Page 3 of 3 )

\begin{tabular}{|c|c|c|c|c|}
\hline Sample Plot & $\begin{array}{l}\text { Sample } \\
\text { Number }\end{array}$ & $\begin{array}{c}\text { Depth } \\
\text { (cm bgs) }\end{array}$ & Matrix & Purpose \\
\hline \multirow{4}{*}{$\mathrm{N}$} & 367N01 & $0-5$ & Soil & Environmental \\
\hline & $367 \mathrm{~N} 02$ & $0-5$ & Soil & Environmental \\
\hline & $367 \mathrm{~N} 03$ & $0-5$ & Soil & Environmental \\
\hline & 367N04 & $0-5$ & Soil & Environmental \\
\hline \multirow{4}{*}{$\mathrm{P}$} & 367P01 & $0-5$ & Soil & Environmental \\
\hline & 367P02 & $0-5$ & Soil & Environmental \\
\hline & 367P03 & $0-5$ & Soil & Environmental \\
\hline & 367P04 & $0-5$ & Soil & Environmental \\
\hline \multirow{5}{*}{ Q } & 367Q01 & 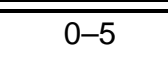 & $\overline{\text { Soil }}$ & Environmental \\
\hline & 367Q02 & $0-5$ & Soil & Environmental \\
\hline & 367Q03 & $0-5$ & Soil & Environmental \\
\hline & 367Q04 & $0-5$ & Soil & Environmental and Full Lab QC \\
\hline & 367Q05 & $0-5$ & Soil & FD of $367 Q 04$ \\
\hline \multirow{4}{*}{$\mathrm{R}$} & 367R01 & $0-5$ & Soil & Environmental \\
\hline & 367R02 & $0-5$ & Soil & Environmental \\
\hline & 367R03 & $0-5$ & Soil & Environmental \\
\hline & 367R04 & $0-5$ & Soil & Environmental \\
\hline
\end{tabular}

a Sample depth was a single $5-\mathrm{cm}$ interval collected from 5 to $30 \mathrm{~cm}$ bgs with the highest radiological screening reading.

FD = Field duplicate 
Table A.3-2

Thermoluminescent Dosimeters at CAU 367

(Page 1 of 3 )

\begin{tabular}{|c|c|c|c|c|}
\hline $\begin{array}{c}\text { TLD } \\
\text { Location }\end{array}$ & $\begin{array}{c}\text { TLD } \\
\text { Number }\end{array}$ & $\begin{array}{l}\text { Date } \\
\text { Placed }\end{array}$ & $\begin{array}{c}\text { Date } \\
\text { Removed }\end{array}$ & Location \\
\hline AT01 & 4432 & $02 / 25 / 2010$ & $06 / 28 / 2010$ & Sample Plot N \\
\hline AT02 & 4348 & $02 / 25 / 2010$ & 06/28/2010 & Sample Plot P \\
\hline AT03 & 5088 & $02 / 25 / 2010$ & 06/28/2010 & Sample Plot Q \\
\hline AT04 & 4949 & $02 / 25 / 2010$ & $06 / 28 / 2010$ & Northwest Vector \\
\hline AT05 & 4886 & $02 / 25 / 2010$ & 06/28/2010 & Sample Plot R \\
\hline AT06 & 4643 & $02 / 25 / 2010$ & $06 / 28 / 2010$ & Northwest Vector \\
\hline AT07 & 4350 & $02 / 25 / 2010$ & 06/28/2010 & Northwest Vector \\
\hline AT08 & 4508 & $02 / 25 / 2010$ & 06/28/2010 & Northwest Vector \\
\hline AT09 & 4477 & $02 / 25 / 2010$ & 06/28/2010 & Sedan Access Road \\
\hline AT10 & 4347 & $02 / 25 / 2010$ & 06/28/2010 & Sedan Access Road \\
\hline AT11 & 4442 & $02 / 26 / 2010$ & 06/28/2010 & Sedan Access Road \\
\hline AT12 & 4751 & $02 / 26 / 2010$ & 06/28/2010 & Circle Road West of Sedan \\
\hline AT13 & 4931 & 02/26/2010 & 06/28/2010 & Circle Road West of Sedan \\
\hline AT14 & 4518 & 02/26/2010 & 06/28/2010 & Circle Road West of Sedan \\
\hline AT15 & 4723 & 02/26/2010 & 06/28/2010 & Circle Road West of Sedan \\
\hline AT16 & 4606 & 03/01/2010 & 06/28/2010 & Circle Road West of Sedan \\
\hline AT17 & 4582 & 03/02/2010 & 06/28/2010 & Circle Road West of Sedan \\
\hline AT18 & 5059 & 03/02/2010 & 06/28/2010 & Circle Road West of Sedan \\
\hline AT19 & 4346 & 03/02/2010 & 06/28/2010 & Circle Road West of Sedan \\
\hline AT20 & 4355 & 03/02/2010 & 06/28/2010 & Road 10-02 West of Uncle \\
\hline AT21 & 4345 & 03/02/2010 & 06/28/2010 & Road 10-02 West of Uncle \\
\hline AT22 & 5055 & 02/26/2010 & 06/28/2010 & Circle Road Northwest of Sedan \\
\hline AT23 & 5185 & $02 / 26 / 2010$ & 06/28/2010 & Circle Road Northwest of Sedan \\
\hline AT24 & 4474 & 03/02/2010 & 06/28/2010 & Sample Plot J \\
\hline \multirow{3}{*}{ AT25 } & 4440 & 03/02/2010 & 06/28/2010 & \multirow{3}{*}{ South Vector } \\
\hline & 3623 & 07/27/2010 & $11 / 02 / 2010$ & \\
\hline & 4112 & 07/27/2010 & $11 / 02 / 2010$ & \\
\hline AT26 & 4327 & 03/02/2010 & 06/28/2010 & South Vector \\
\hline AT27 & 4777 & 03/02/2010 & 06/29/2010 & South Vector \\
\hline
\end{tabular}


Table A.3-2

Thermoluminescent Dosimeters at CAU 367

(Page 2 of 3 )

\begin{tabular}{|c|c|c|c|c|}
\hline $\begin{array}{c}\text { TLD } \\
\text { Location }\end{array}$ & $\begin{array}{c}\text { TLD } \\
\text { Number }\end{array}$ & $\begin{array}{c}\text { Date } \\
\text { Placed }\end{array}$ & $\begin{array}{c}\text { Date } \\
\text { Removed }\end{array}$ & Location \\
\hline$\overline{\text { AT28 }}$ & 44557 & 03/02/2010 & $06 / 28 / 2010$ & Sample Plot L \\
\hline \multirow{3}{*}{ AT29 } & 4576 & $03 / 02 / 2010$ & $06 / 28 / 2010$ & \multirow{3}{*}{ South Vector } \\
\hline & 3795 & $07 / 27 / 2010$ & $11 / 02 / 2010$ & \\
\hline & 3464 & $07 / 27 / 2010$ & $11 / 02 / 2010$ & \\
\hline AT30 & 4513 & $03 / 02 / 2010$ & $06 / 28 / 2010$ & Sample Plot M \\
\hline AT31 & 4691 & $03 / 02 / 2010$ & $06 / 28 / 2010$ & South Vector \\
\hline AT32 & 5262 & $03 / 02 / 2010$ & $06 / 28 / 2010$ & South Vector \\
\hline AT33 & 5251 & $03 / 01 / 2010$ & 06/28/2010 & Sample Plot E \\
\hline AT34 & 4838 & $03 / 01 / 2010$ & 06/28/2010 & Sample Plot F \\
\hline \multirow{3}{*}{ AT35 } & 5163 & $03 / 01 / 2010$ & $06 / 28 / 2010$ & \multirow{3}{*}{ East Vector } \\
\hline & 4165 & $07 / 27 / 2010$ & $11 / 02 / 2010$ & \\
\hline & 3116 & $07 / 27 / 2010$ & $11 / 02 / 2010$ & \\
\hline AT36 & 4998 & $03 / 01 / 2010$ & 06/28/2010 & Sample Plot G \\
\hline AT37 & 4441 & 03/01/2010 & 06/28/2010 & East Vector \\
\hline AT38 & 4604 & 03/01/2010 & 06/28/2010 & East Vector \\
\hline AT39 & 4678 & 03/01/2010 & 06/28/2010 & Sample Plot H \\
\hline AT40 & 4655 & 03/01/2010 & 06/28/2010 & East Vector \\
\hline AT41 & 5008 & 03/01/2010 & 06/28/2010 & Sample Plot B \\
\hline AT42 & 4746 & 03/01/2010 & 06/28/2010 & Sample Plot A \\
\hline AT43 & 4430 & 03/01/2010 & 06/28/2010 & Northeast Vector \\
\hline AT44 & 4953 & 03/01/2010 & 06/28/2010 & Sample Plot C \\
\hline AT45 & 4673 & 03/01/2010 & 06/28/2010 & Sample Plot D \\
\hline AT46 & 4378 & $03 / 01 / 2010$ & $06 / 28 / 2010$ & Northeast Vector \\
\hline AT47 & 4752 & 03/01/2010 & 06/28/2010 & Northeast Vector \\
\hline AT48 & 4319 & 03/01/2010 & 06/28/2010 & Northeast Vector \\
\hline AT49 & 4792 & 03/01/2010 & 06/28/2010 & Circle Road Northeast of Sedan \\
\hline AT50 & 5162 & $03 / 01 / 2010$ & $06 / 28 / 2010$ & Circle Road Northeast of Sedan \\
\hline AT51 & 4528 & 03/02/2010 & 06/30/2010 & East of Uncle and Ess \\
\hline
\end{tabular}


Table A.3-2

Thermoluminescent Dosimeters at CAU 367

(Page 3 of 3)

\begin{tabular}{|c|c|c|c|c|}
\hline $\begin{array}{c}\text { TLD } \\
\text { Location }\end{array}$ & $\begin{array}{c}\text { TLD } \\
\text { Number }\end{array}$ & $\begin{array}{c}\text { Date } \\
\text { Placed }\end{array}$ & $\begin{array}{c}\text { Date } \\
\text { Removed }\end{array}$ & Location \\
\hline AT52 & 4538 & 03/01/2010 & 06/29/2010 & $\begin{array}{c}\text { Background } \\
\text { (Road 10-03 and Circle Road) }\end{array}$ \\
\hline AT53 & 4367 & 03/01/2010 & $06 / 29 / 2010$ & Road 10-03 and Mercury Highway \\
\hline AT54 & 4607 & 02/26/2010 & $06 / 28 / 2010$ & Road 10-02 North of Circle Road \\
\hline \multirow{3}{*}{ AT55 } & 5082 & 03/15/2010 & 06/28/2010 & \multirow{3}{*}{ Sample Plot $\mathrm{K}$} \\
\hline & 1234 & $07 / 27 / 2010$ & $11 / 02 / 2010$ & \\
\hline & 3980 & $07 / 27 / 2010$ & $11 / 02 / 2010$ & \\
\hline AT56 & 3280 & 07/27/2010 & $11 / 02 / 2010$ & $5,500 \mathrm{~m}$ North of Sedan Crater \\
\hline AT57 & 3717 & $07 / 27 / 2010$ & $11 / 02 / 2010$ & $3,800 \mathrm{~m}$ Northeast of Sedan Crater \\
\hline AT58 & 4186 & $07 / 27 / 2010$ & $11 / 02 / 2010$ & $\begin{array}{c}\text { Background } \\
(4,000 \mathrm{~m} \text { East of Sedan Crater })\end{array}$ \\
\hline AT59 & 1078 & $07 / 27 / 2010$ & $11 / 02 / 2010$ & $5,500 \mathrm{~m}$ Southeast of Sedan Crater \\
\hline AT60 & 3184 & $07 / 27 / 2010$ & $11 / 02 / 2010$ & $\begin{array}{c}\text { Background } \\
(4,000 \mathrm{~m} \text { Southwest of Sedan Crater) }\end{array}$ \\
\hline
\end{tabular}

crater CAS (i.e., the area in which it was assumed a dose of greater than the FAL was present) was defined by the visual survey and recorded using a GPS instrument. The default contamination boundary is further discussed in Section A.3.3. The visual survey of potential surface migration pathways was conducted to determine whether surface features were present where contaminants could concentrate and/or move beyond the limits of each CAS. This survey did not identify any areas where contamination might concentrate (e.g., sedimentation areas) or surface migration pathways (e.g., drainages). The site conditions suggest that any surface migration of contamination from the three crater CASs flows directly into surrounding craters or is halted by the crater rims. Thus, no preferential pathways for migration from the three crater CASs or areas of concentrated contamination were identified.

\section{A.3.1.2 Radiological Surveys}

The CAU 367 investigation utilized the results of aerial and ground-based radiological surveys to guide the selection of soil sample and TLD locations and to evaluate the contaminant distribution at 
CAU 367. Aerial surveys were completed in 1994 and 2009, and ground-based surveys were completed in 2010.

\section{A.3.1.2.1 Aerial Radiological Surveys}

The initial design of the CAU 367 sampling approach presented in the CAIP was based in part on 1994 gross count gamma survey data (BN, 1999). In October 2009, another aerial radiological survey of the area was completed at an altitude of $50 \mathrm{ft}$ (NNSA/NSO, 2010a). The results of the 2009 survey were used to adjust the orientation of the four sampling vectors, guide the placement of TLDs, and select areas for ground-based radiological surveys. Because the 1994 survey area was larger than that of the 2009 survey, the 1994 survey was considered in the placement of background TLDs.

\section{A.3.1.2.2 Ground-Based Radiological Surveys}

The results of the ground-based radiological surveys were used to select the locations of four sample plots on each vector (see Section A.3.1.3.2). These results also provided preliminary validation of the CSM assumption made in the CAIP that radioactivity decreases as the distance from the source increases. Survey data for the northwest, northeast, and east vectors clearly show this trend in relation to the Sedan release (Figure A.3-1). Ground-based radiological surveys completed along the south vector in the area of the Ess and Uncle craters indicated elevated radioactivity between the two craters and at an isolated location approximately $275 \mathrm{~m}$ southeast of the craters (Figure A.3-2). The identified areas of elevated radioactivity along the south vector are generally consistent with the 2009 aerial survey. The highest activities were identified between the two craters and at intermittent intervals on the perimeter of each crater. The surveys at the location south of the two craters suggest an isolated occurrence of elevated radioactivity, the source of which is suspected to be the Uncle test and/or the Ess test.

While these area-specific surveys provided usable data to support selection of the sample plots, the surveys were of limited use in visualizing the contamination plume as a whole. Large areas of land existed between the vectors for which no ground-based radiological data were available. In order to fill these data gaps, a vehicle-assisted survey was conducted over an area of approximately 2,200 acres surrounding the three crater sites (Figure A.3-3). The PRM-470 instrument and GPS datalogger collected continuous measurements at approximately $3 \mathrm{ft}$ above the ground 


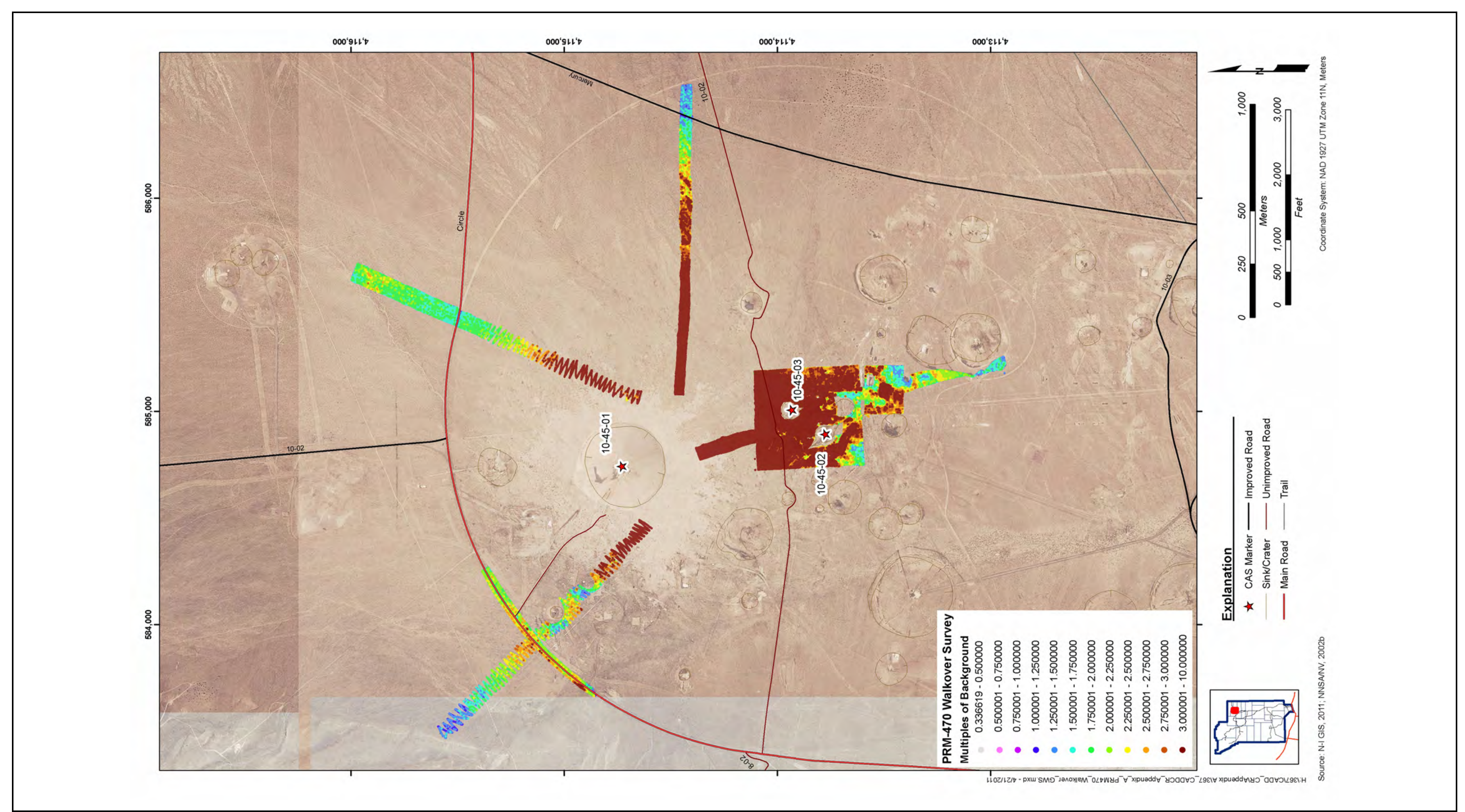

Radiological Survey Results (Four Vectors) 


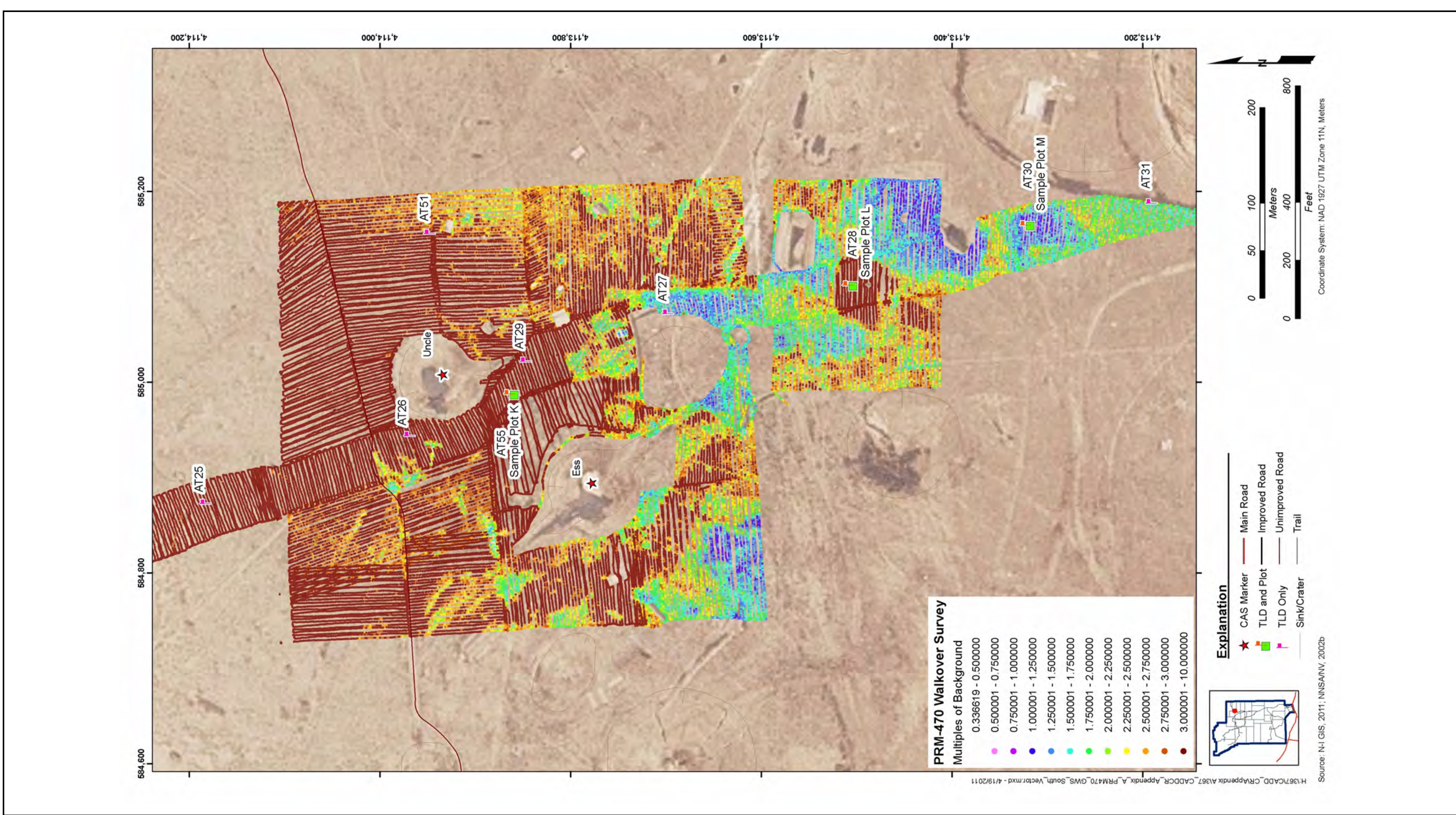


surface along east-west transects approximately $100 \mathrm{ft}$ apart. Three small areas were refined by additional transects, spaced approximately $50 \mathrm{ft}$ apart. The results of these ground-based surveys provided better resolution along the edges of the contamination isopleths than the 2009 gross count flyover data.

\section{A.3.1.2.3 Radiological Surveys Using the FIDLER}

Ground-based radiological surveys at CAU 367 for the detection of Am-241 were conducted using a FIDLER. The selection of FIDLER survey locations was based on the 2009 aerial Am-241 survey results. The FIDLER survey completed along the east vector did not detect elevated Am-241 activity consistent with the aerial survey, but instead indicated a general decreasing trend with increasing distance from the Sedan crater consistent with the gamma radiological surveys. The FIDLER surveys completed along portions of the northeast and south vectors had similar results. The fact that FIDLER survey results were consistent with the ground-based gamma surveys and not the aerial Am-241 survey suggests that the FIDLER instrument was registering a response from activation products and fallout near Sedan ground zero (both low and high energy gamma radiation) in addition to the low-energy gamma ray from the Am-241 contaminant in soils contaminated with plutonium. This difference was attributed to the fact that the FIDLER does not have the same spectroscopic capabilities as the flyover equipment.

Subsequent evaluation of the soil sample data collected at the four sample plots along the east vector indicated that the internal dose (which includes americium and plutonium contributions to dose) in the middle of the east vector was higher than that at each end of the vector (Figure A.3-4). This trend was not apparent in the FIDLER surveys, which suggested a decreasing americium/plutonium concentration with increasing distance from the Sedan crater. The 95 percent UCL internal dose estimates for sample plots $\mathrm{F}$ and $\mathrm{G}$, both located in the middle of the east vector, were 2.33 and $2.68 \mathrm{pCi} / \mathrm{g}$, respectively (Table A.3-4). The locations of these two sample plots roughly coincide with the location of highest Am-241 measured by the aerial survey.

As evidenced by the 2009 aerial survey results and supported by the analytical results from the sample plots on the east vector, it appears that the atmospheric distribution of americium and plutonium produced by the Sedan test was not uniform and was concentrated in areas located east and northwest of the Sedan crater. The reason for this nonuniform distribution is unclear, however, it may 


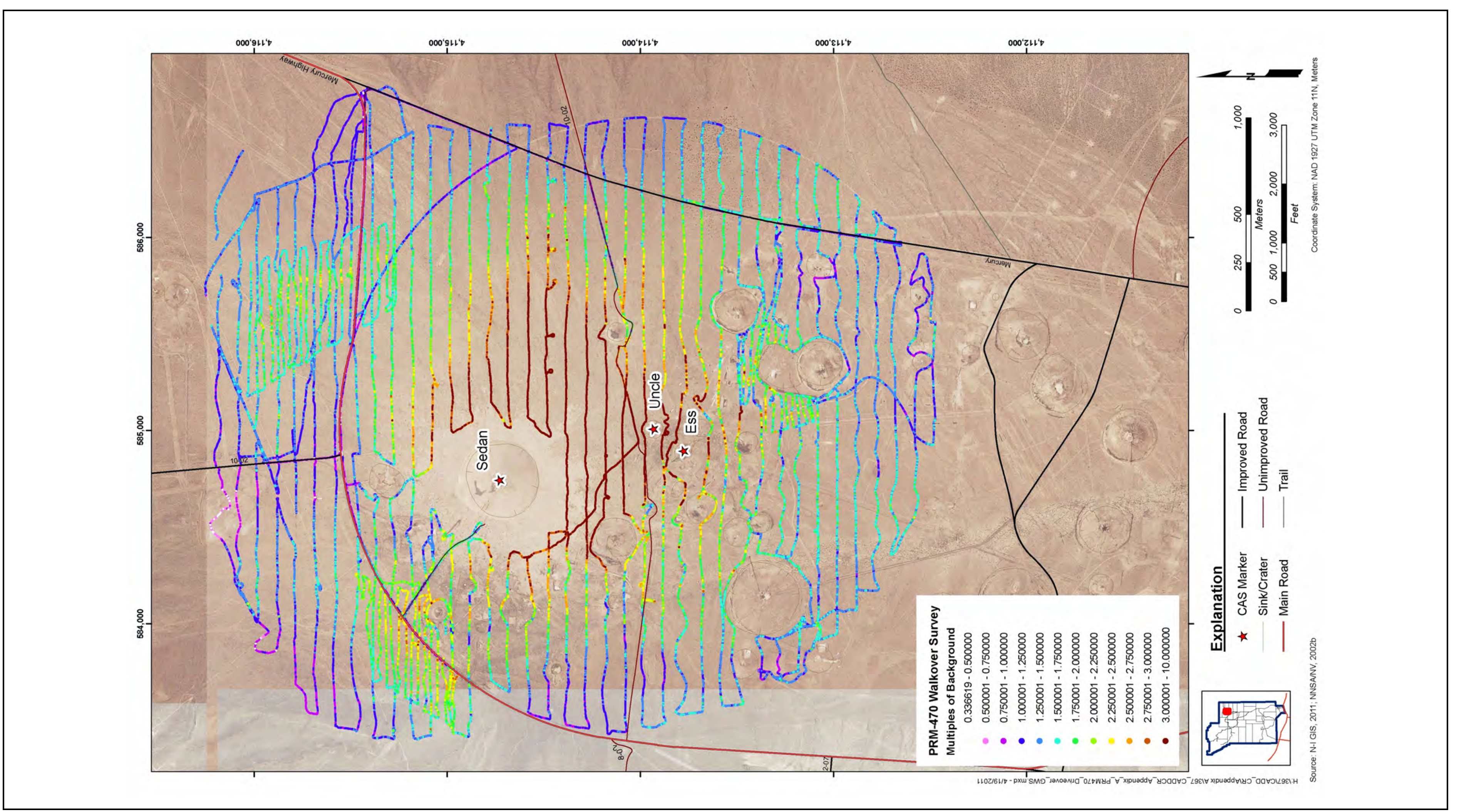


be due to the fractionation of plutonium after detonation and/or the direction of the blowouts from the Sedan test. After a nuclear detonation, plutonium volatilizes and then solidifies in a matter of seconds. The solidified plutonium particles in fallout may be preferentially deposited by wind and/or the conditions created by the explosion, resulting in a nonuniform distribution pattern. Another possible explanation is suggested by the film of the Sedan test, which shows a significant initial blowout to the southeast of Sedan ground zero followed by a smaller blowout to the northwest (AEC, 1962). These blowouts appear to roughly coincide with the results of the 2009 aerial radiological survey, which show the highest americium concentrations to the east and northwest of the Sedan crater. As indicated in the CAIP, these blowouts are presumed to contain a higher concentration of fission material and activated soil than the remaining material displaced by the detonation.

As a result of the evaluation of FIDLER data, the 2009 americium survey results, and the analytical results from the sample plots, the FIDLER survey data were not considered representative of plutonium concentrations and are not presented in this document.

\section{A.3.1.3 Sample Collection}

The primary release was investigated through the collection of surface and subsurface soil samples and TLD measurements (i.e., samples). A minimum number of samples is required to ensure sufficient confidence in dose statistics such as the average and 95 percent UCL (EPA, 2006). As stated in the CAIP (NNSA/NSO, 2009), if the minimum sample size criterion cannot be met, it must be assumed that contamination exceeds the FAL. The minimum sample number requirements for all sample plots and TLD locations were met at CAU 367. The calculation of minimum sample size and the results for sample plots and TLD locations are presented in Appendix B.

\section{A.3.1.3.1 Thermoluminescent Dosimeter Samples}

A total of 68 TLDs were placed during the investigation at CAU 367: 65 were installed to measure external dose from the primary release (environmental TLDs) and 3 to measure background activity (background TLDs) (Table A.3-2). The locations of the background TLDs are discussed in Section A.2.2.6. The locations for the 65 environmental TLDs were selected based on the sampling 
approach outlined in the CAIP, the 1994 aerial radiological survey, and the preliminary results of the 2009 aerial survey, and are listed below:

- Environmental TLDs were generally spaced evenly on each vector. The TLD locations on the vectors are as follows: on the northwest vector, 8 TLDs were installed at 8 locations (AT01-AT08); on the northeast vector, 8 TLDs were installed at 8 locations (AT41-AT48); on the east vector, 10 TLDs were installed at 8 locations (AT33-AT40); on the south vector, 17 TLDs were installed at 11 locations (AT24-AT32, AT51, and AT55). In total, 43 TLDs were installed at the locations on the vectors.

- $\quad$ Two TLDs were placed at two locations along the Sedan crater access road (AT10 and AT11) and one TLD was placed at a location near the visitors platform (AT09). These TLDs were placed to confirm existing dose data in these areas.

- $\quad$ Five TLDs were placed at five locations just outside the posted Contamination Area surrounding a group of nuclear tests to the west/northwest of the Sedan crater (AT15-AT19) (see Section 1.2 for a discussion of this group of tests). The purpose of these TLDs was to confirm the western edge of the Sedan contamination plume in an effort to make a distinction between the releases from CAU 367 and the releases from the group of tests to the west.

- Seven TLDs were placed at seven locations along Circle Road to the northwest and northeast of the Sedan crater (AT12-AT14, AT22, AT23, AT49, and AT50). These locations were selected based on the 2009 aerial survey results that suggested areas of elevated man-made radioactivity.

- Two TLDs were placed on both sides of the 10-02 Road, which runs east-west across the site just above the Uncle and Ess craters (AT20 and AT21). The locations for these TLDs were selected based on the 2009 man-made radioactivity isopleths at the point where an isopleth crosses the road in a finger-like projection (Figure A.2-1).

- $\quad$ Five TLDs were originally placed in locations believed to be unaffected by CAU 367 activities (AT53, AT54, AT56, AT57, and AT59). As explained in Section A.2.2.6, however, these locations were not found representative of background, and the associated data were not used in background calculations. Instead, these data were evaluated as part of the environmental TLD data set for CAU 367.

The TLDs provide an integrated, unbiased measurement of dose from the area at which they were placed. The measurements obtained were used to calculate the external dose component of the TED (see Section A.3.2.2). In order to ensure that an adequate number of TLD measurements were collected at each location, the minimum number of samples required was calculated (see Appendix B). The minimum number of TLD samples was met or exceeded at each TLD location at CAU 367. Table A.3-2 lists the total inventory of TLDs installed for the CAU 367 
investigation, and TLD results are discussed in Section A.3.2.2. Details of the environmental monitoring TLD program and TLD QC are presented in Section A.6.0.

\section{A.3.1.3.2 Soil Samples}

The selection of soil sample locations was based on the strategy developed during the DQO process as presented in the CAIP (NNSA/NSO, 2009). The sampling strategy for CAU 367 included the judgmental selection of sample plot locations and the probabilistic selection of composite sample (aliquot) locations within each plot. Sample plot locations were established based on the interpretation of the 1994 and 2009 aerial radiological survey data (BN,1999; NNSA/NSO, 2010a), ground-based radiological surveys, RIDP data (McArthur and Mead, 1987; Gray et al., 2007), and site conditions.

Four sample plots were located along each of the four vectors. From each of the 16 sample plots, 4 composite surface soil samples were collected. Four composite subsurface soil samples were collected from sample plot K. The sample locations are listed in Table A.3-1 and depicted in Figure A.2-1. All soil samples collected from the sample plots were analyzed for gamma spectroscopy, Sr-90, and isotopic U, Pu, and Am.

The soil sample data was used to calculate the internal dose component of the TED (see Section A.3.2.1). In order to ensure that an adequate number of soil samples were collected at each sample plot, the minimum number of samples required was calculated (see Appendix B). The minimum number of soil samples was met or exceeded at each sample plot at CAU 367. Soil sample results are discussed in Section A.3.2.1.

\section{A.3.1.4 Deviations}

Table A.3-3 describes the deviations from planned activities associated with the investigation of the primary release at CAU 367. The first deviation involved the requirement in the CAIP that at least one sample plot be established on each vector at a location expected to present a TED greater than 25 mrem/IA-yr and at least one plot be established at a location expected to present a TED less than 25 mrem/IA-yr. The second deviation involved the field-screening criteria used to evaluate screening 
borings at potential buried contamination locations. These deviations did not bring about any adverse impacts on the CAI or the resolution of DQOs for CAU 367.

\section{A.3.2 Results}

The following sections provide analytical and computational results for samples collected for investigation of the primary release at the crater CASs as outlined in the CAIP (NNSA/NSO, 2009). The analytical parameters and laboratory methods used during this investigation are discussed in Section A.2.4 and listed in Table A.2-1.

The internal dose calculated from soil sample results and the external dose calculated from TLD measurements were combined to determine TED at each primary release sample location. The primary release results are reported as doses and are compared to the PAL of 25 mrem/IA-yr and the FAL of 25 mrem/RW-yr.

Data tables listing the analytical results for individual radionuclides in each composite plot sample and the TLD element measurements are presented in Appendix F.

\section{A.3.2.1 Internal Dose Estimates}

Estimates for the internal dose that a receptor would receive at each sample plot were determined as described in Section A.2.2.5. Of the 16 sample plots, the locations of the 2 highest calculated internal doses are sample plots F and G (Table A.3-4), both on the east vector. These results are consistent with the 2009 Am-241 aerial radiological survey results and confirm that at least one sample plot has been placed at the highest Am-241 reading outside the default contamination boundary in accordance with the CAIP (Figure A.3-4).

The 95 percent UCL of the average internal dose at each sample plot for each exposure scenario is presented in Table A.3-5.

\section{A.3.2.1.1 Buried Contamination}

To address the potential presence of layers of contamination from the Uncle test and/or Ess test that may have been buried by or mixed with fallout from the Sedan test, six screening borings (1-6) were 
Table A.3-3

Deviations from CAIP: Primary Release

\begin{tabular}{|c|c|c|c|}
\hline CAIP Section & Description & Deviation & Potential Adverse Impact on CAI \\
\hline $\begin{array}{c}\text { 4.2.2.1, } \\
\text { Test Releases }\end{array}$ & $\begin{array}{l}\text { "The Decision II sample plot } \\
\text { locations must meet the } \\
\text { criterion that at least one sample } \\
\text { plot will be located within the } \\
25 \text { mrem/IA-yr boundary and at } \\
\text { least one sample plot will be located } \\
\text { outside this boundary." }\end{array}$ & $\begin{array}{l}\text { Four plots were placed on each of the four } \\
\text { vectors based on the } 2009 \text { aerial survey } \\
\text { results. The requirement for one plot inside } \\
\text { and one plot outside the } 25-\mathrm{mrem} / \mathrm{yr}-\mathrm{IA} \\
\text { boundary was met on all vectors except the } \\
\text { northwest vector. There are no sample plots } \\
\text { on the northwest vector that are outside the } \\
25-\mathrm{mrem} / \mathrm{yr}-\mathrm{IA} \text { boundary. Calculated TEDs } \\
\text { for sample plots Q and R on the northwest } \\
\text { vector are less than } 25 \text { mrem/IA-yr; however, } \\
\text { both plots are located inside the } \\
25-\mathrm{mrem} / \mathrm{IA} \text {-yr boundary. }\end{array}$ & $\begin{array}{l}\text { None. Although a sample plot was not } \\
\text { established outside the } 25-m r e m / I A-y r \text { boundary } \\
\text { on the northwest vector, sufficient data are } \\
\text { available for this area to calculate the TED and } \\
\text { adequately define the } 25 \text {-mrem/IA-yr boundary. } \\
\text { There are three TLDs not associated with sample } \\
\text { plots located outside the } 25-m r e m / I A-y r \text { boundary } \\
\text { on the northwest vector. The TED was } \\
\text { conservatively calculated at these locations by } \\
\text { using a ratio of internal to external dose measured } \\
\text { at the sample plot with the highest internal dose } \\
\text { estimate. In addition, the TED at sampling } \\
\text { locations along Circle Road and the ground-based } \\
\text { radiological surveys were used to further refine } \\
\text { the 25-mrem/IA-yr boundary in this area. }\end{array}$ \\
\hline $\begin{array}{c}\text { A.9.1.3, } \\
\text { Determination } \\
\text { of Buried } \\
\text { Contamination }\end{array}$ & $\begin{array}{l}\text { "If screening results are not } \\
\text { significantly different (at least } \\
50 \text { percent difference between } \\
\text { samples) than the surface results, it } \\
\text { will be assumed that buried } \\
\text { contamination does not exist...." }\end{array}$ & $\begin{array}{l}\text { The following revised criteria were used in } \\
\text { determining the presence of buried } \\
\text { contamination: Buried contamination was } \\
\text { deemed present if the depth interval reading } \\
\text { exceeded the FSL and there was a greater } \\
\text { than } 20 \text { percent difference between the depth } \\
\text { interval reading and the surface soil reading. }\end{array}$ & $\begin{array}{l}\text { None. It was necessary to redefine the screening } \\
\text { criteria to account for background levels. The } \\
\text { original screening criteria (50 percent difference } \\
\text { among sample intervals) would have provided } \\
\text { only a relative comparison of instrument readings } \\
\text { without the determination of the presence of } \\
\text { contamination. This deviation resulted in a } \\
\text { positive impact on the investigation in that it } \\
\text { allowed for a field-screening methodology that is } \\
\text { more specific to the site through the use of } \\
\text { site-specific background measurements. }\end{array}$ \\
\hline
\end{tabular}

\section{UNCONTROLLED When Printed}


Table A.3-4

Internal Dose Estimates

\begin{tabular}{|c|c|c|c||}
\hline $\begin{array}{c}\text { Sample } \\
\text { Plot }\end{array}$ & $\begin{array}{c}\text { Average } \\
\text { (mrem/IA-yr) }\end{array}$ & $\begin{array}{c}\text { Standard } \\
\text { Deviation }\end{array}$ & $\begin{array}{c}\text { 95\% UCL } \\
\text { (mrem/IA-yr) }\end{array}$ \\
\hline \hline A & 1.43 & 0.155 & 1.61 \\
\hline B & 0.539 & 0.110 & 0.669 \\
\hline C & 0.625 & 0.024 & 0.653 \\
\hline D & 0.474 & 0.023 & 0.502 \\
\hline E & 1.83 & 0.109 & 1.93 \\
\hline F & 2.18 & 0.130 & 2.33 \\
\hline G & 2.40 & 0.234 & 2.68 \\
\hline H & 0.652 & 0.199 & 0.887 \\
\hline J & 0.924 & 0.082 & 1.02 \\
\hline K & 1.26 & 0.324 & 1.57 \\
\hline K' & 1.05 & 0.766 & 1.96 \\
\hline L & 0.517 & 0.137 & 0.679 \\
\hline M & 0.028 & 0.019 & 0.0456 \\
\hline N & 1.35 & 0.105 & 1.47 \\
\hline P & 0.738 & 0.060 & 0.809 \\
\hline Q & 0.069 & 0.033 & 0.100 \\
\hline R & 1.52 & 0.280 & 1.85 \\
\hline
\end{tabular}

Note: The values listed in the row for plot $K^{\prime}$ are the subsurface soil sample values. Values have been rounded to three significant digits. 


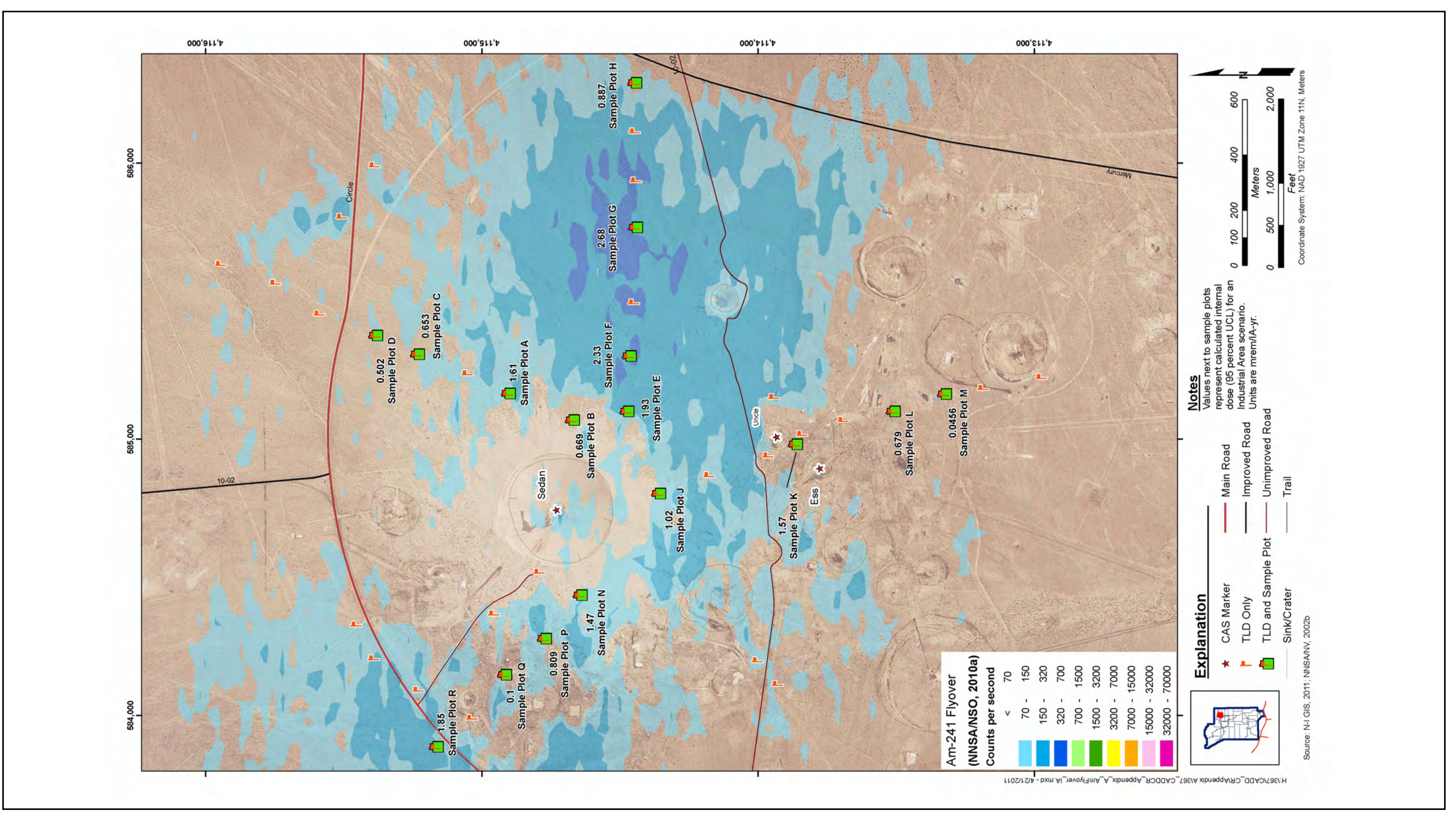

Figure A.3-4

Internal Dose Results and Americium Aerial Survey Results 
Table A.3-5

Internal Dose Estimates (95 Percent UCL) at Sample Plots for Each Exposure Scenario

\begin{tabular}{|c|c|c|c|}
\hline Sample Plot & $\begin{array}{l}\text { Industrial Area } \\
\text { (mrem/IA-yr) }\end{array}$ & $\begin{array}{l}\text { Remote Work Area } \\
\text { (mrem/RW-yr) }\end{array}$ & $\begin{array}{c}\text { Occasional Use Area } \\
\text { (mrem/OU-yr) }\end{array}$ \\
\hline$A$ & 1.61 & 0.280 & 0.099 \\
\hline B & 0.669 & 0.116 & 0.041 \\
\hline $\mathrm{C}$ & 0.653 & 0.113 & 0.040 \\
\hline $\mathrm{D}$ & 0.502 & 0.087 & 0.031 \\
\hline$E$ & 1.93 & 0.336 & 0.119 \\
\hline $\mathrm{F}$ & 2.33 & 0.406 & 0.143 \\
\hline G & 2.68 & 0.466 & 0.165 \\
\hline $\mathrm{H}$ & 0.887 & 0.154 & 0.054 \\
\hline $\mathrm{J}$ & 1.02 & 0.177 & 0.063 \\
\hline $\mathrm{K}$ & 1.57 & 0.272 & 0.096 \\
\hline $\mathrm{L}$ & 0.679 & 0.116 & 0.040 \\
\hline M & 0.046 & 0.008 & 0.003 \\
\hline $\mathrm{N}$ & 1.48 & 0.256 & 0.090 \\
\hline $\mathrm{P}$ & 0.809 & 0.140 & 0.050 \\
\hline Q & 0.100 & 0.017 & 0.006 \\
\hline $\mathrm{R}$ & 1.85 & 0.323 & 0.114 \\
\hline
\end{tabular}

Note: Values have been rounded to three significant digits.

installed. As specified in the CAIP, two of these borings were placed next to the first sample plot on each of the vectors nearest to the Uncle and Ess craters (sample plots $\mathrm{K}$ and $\mathrm{E}$ ); the remaining four borings were placed on the south vector. It was postulated that buried contamination would be more easily identified at locations near the Uncle and Ess craters where the ejecta layer deposited by the Sedan test was thin. The thickness of the ejecta deposited by the Sedan test was measured following the detonation and is presented as isopach contours in Figure A.3-5.

As detailed in Table A.3-3, the criteria for determining the presence of buried contamination was revised from the criteria stated in the CAIP. The revised criteria used at the screening boring locations consisted of a comparison of the radiological readings at each depth interval to the daily FSLs and to the surface soil readings. If either alpha or beta measurements exceeded these criteria, it 
was assumed that buried contamination exists. Based on radiological field screening, buried contamination was indicated at three of the six borings: screening boring 2 at 10-20 cm bgs, boring 3 at $10-15 \mathrm{~cm}$ bgs, and boring 5 at 5-15 cm bgs. Figure A.3-5 and Table A.3-6 present the screening boring locations and field-screening data, respectively.

The sample plot adjacent to screening boring 3 (plot K) was selected for sampling due to its location between the Uncle and Ess craters and because the associated screening boring had the highest field screening readings of the six borings. The subsurface soil samples were collected and composited from the same aliquot locations as the surface samples within the sample plot. A continuous soil core was collected at each aliquot location using a split-spoon sampler driven to a depth of $30 \mathrm{~cm}$. Soil was removed from the sampler in 5-cm increments (0 to $5 \mathrm{~cm}, 5$ to $10 \mathrm{~cm}$, etc.), and the depth increments were individually field screened for radioactivity. The depth interval with the highest radiological measurement at each aliquot location, excluding the interval of $0-5 \mathrm{~cm}$, was composited. In order to collect a sufficient soil volume for the sample, a second boring was installed adjacent to the original aliquot location and the selected interval was composited with the sample. The collection of the intervals with the highest radiological readings accounts for the potential of nonuniform stratification of fallout and ejecta from the three tests. Except for the selection of depth intervals, the processing and handling of subsurface soil composite samples was the same as the surface soil samples (Section A.2.2.4). The four composite subsurface soil samples collected from sample plot K (367K06-367K09) were analyzed for gamma spectroscopy, Sr-90, and isotopic U, Pu, and Am. The sample results for the four subsurface soil samples are found in Appendix F.

As shown in Table A.3-4, the average internal dose estimated from surface samples at sample plot K was higher than the average subsurface dose (sample plot K’). Based on the visual and radioactivity screening tools utilized during the CAI, it was not possible to ascertain whether the subsurface contamination present was layered or comingled, or to definitively isolate the contamination source (i.e., Uncle, Ess, or Sedan test). However, the investigation has shown that the potential dose in the subsurface is lower than that at the surface. In accordance with the CAIP, the samples with the highest dose (surface or subsurface) shall be used to estimate internal dose at that location. Thus, the surface internal dose estimation was used in the calculation of TED at sample plot K, and the subsurface internal dose data were not considered in the evaluation of the primary release at CAU 367. 


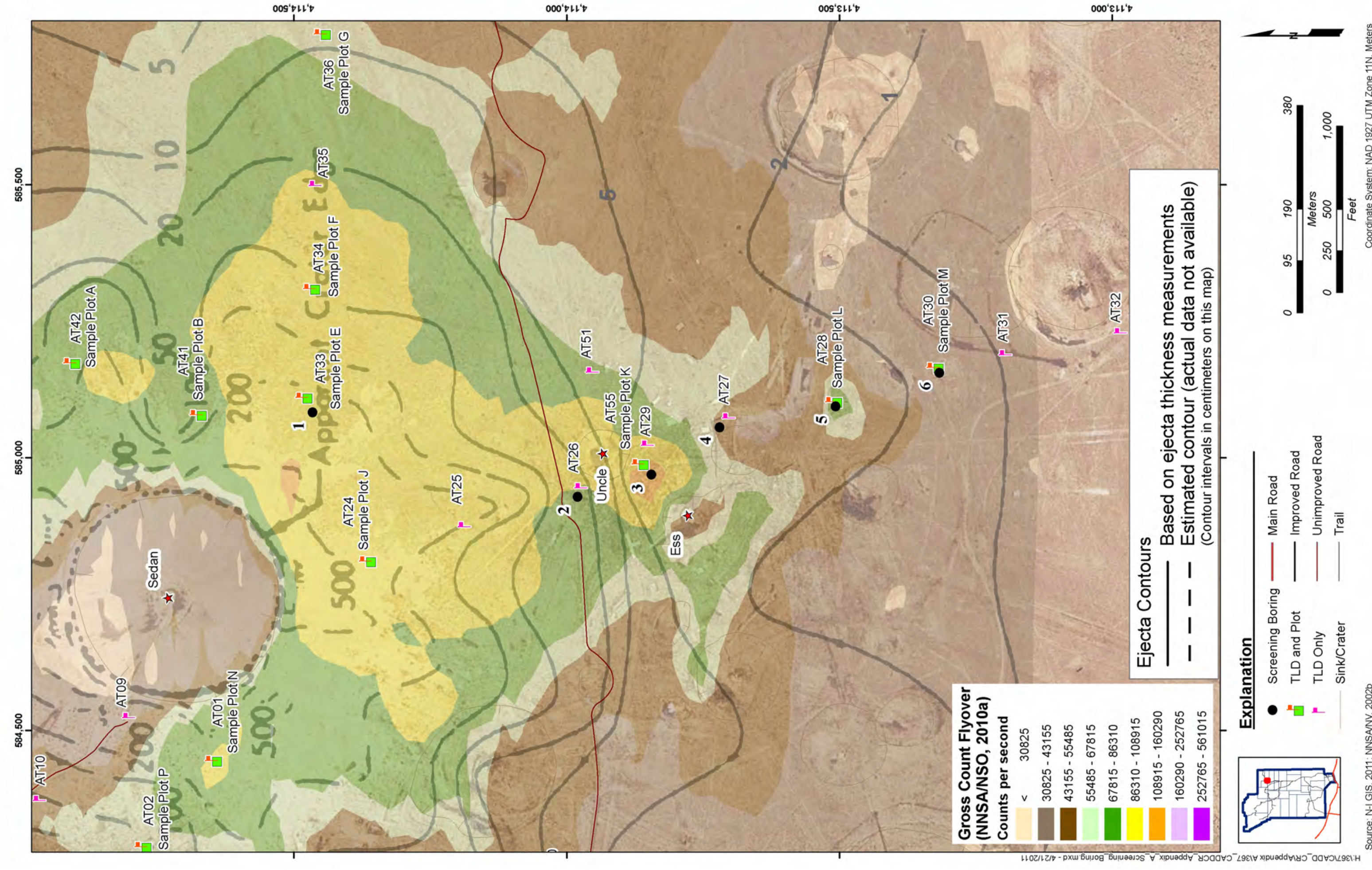

Figure A.3-5

Screening Boring Locations and Sedan Ejecta Thickness Contours 
Table A.3-6

Field Screening Data for Screening Borings

(Page 1 of 2)

\begin{tabular}{|c|c|c|c|c|c|c|c|}
\hline \multirow{2}{*}{$\begin{array}{l}\text { Boring } \\
\text { Number }\end{array}$} & \multirow{2}{*}{ Sample Plot } & \multirow{2}{*}{$\begin{array}{c}\text { TLD } \\
\text { Location }\end{array}$} & \multirow{2}{*}{$\begin{array}{l}\text { Depth } \\
\text { (cm bgs) }\end{array}$} & \multicolumn{4}{|c|}{$\begin{array}{l}\text { Field-Screening Results } \\
\left(\mathrm{dpm} / 100 \mathrm{~cm}^{2}\right)\end{array}$} \\
\hline & & & & Alpha & $\begin{array}{l}\text { Alpha } \\
\text { FSL }\end{array}$ & Beta & $\begin{array}{l}\text { Beta } \\
\text { FSL }\end{array}$ \\
\hline \multirow{6}{*}{1} & \multirow{6}{*}{$E$} & \multirow{6}{*}{ AT33 } & $0-5$ & 253 & \multirow{6}{*}{196} & 9,496 & \multirow{6}{*}{4,118} \\
\hline & & & $5-10$ & 171 & & 6,571 & \\
\hline & & & 10-15 & 234 & & 9,438 & \\
\hline & & & $15-20$ & 209 & & 7,674 & \\
\hline & & & $20-25$ & 266 & & 7,176 & \\
\hline & & & $25-30$ & 222 & & 7,556 & \\
\hline \multirow{6}{*}{2} & \multirow{6}{*}{ No plot } & \multirow{6}{*}{ AT26 } & $0-5$ & 101 & \multirow{6}{*}{147} & 11,200 & \multirow{6}{*}{4,129} \\
\hline & & & $5-10$ & 33.8 & & 10,600 & \\
\hline & & & 10-15 & 67.6 & & 16,600 & \\
\hline & & & $15-20$ & 81.6 & & 30,500 & \\
\hline & & & $20-25$ & 94.6 & & 7,821 & \\
\hline & & & $25-30$ & 94.6 & & 8,761 & \\
\hline \multirow{6}{*}{3} & \multirow{6}{*}{$\mathrm{K}$} & \multirow{6}{*}{ AT55 } & $0-5$ & 120 & \multirow{6}{*}{196} & 12,100 & \multirow{6}{*}{4,118} \\
\hline & & & $5-10$ & 101 & & 14,400 & \\
\hline & & & $10-15$ & 114 & & 15,600 & \\
\hline & & & $15-20$ & 95 & & 14,400 & \\
\hline & & & $20-25$ & 133 & & 12,700 & \\
\hline & & & $25-30$ & 50.6 & & 11,300 & \\
\hline \multirow{6}{*}{4} & \multirow{6}{*}{ No plot } & \multirow{6}{*}{ AT27 } & $0-5$ & 60.8 & \multirow{6}{*}{147} & 3,728 & \multirow{6}{*}{4,129} \\
\hline & & & $5-10$ & 47.3 & & 3,684 & \\
\hline & & & $10-15$ & 20.3 & & 3,184 & \\
\hline & & & $15-20$ & 20.3 & & 3,296 & \\
\hline & & & $20-25$ & 40.5 & & 2,888 & \\
\hline & & & $25-30$ & 27 & & 2,692 & \\
\hline
\end{tabular}


Table A.3-6

\section{Field Screening Data for Screening Borings}

(Page 2 of 2)

\begin{tabular}{|c|c|c|c|c|c|c|c|}
\hline \multirow{2}{*}{$\begin{array}{l}\text { Boring } \\
\text { Number }\end{array}$} & \multirow{2}{*}{ Sample Plot } & \multirow{2}{*}{$\begin{array}{c}\text { TLD } \\
\text { Location }\end{array}$} & \multirow{2}{*}{$\begin{array}{c}\text { Depth } \\
\text { (cm bgs) }\end{array}$} & \multicolumn{4}{|c|}{$\begin{array}{l}\text { Field-Screening Results } \\
\left(\mathrm{dpm} / 100 \mathrm{~cm}^{2}\right)\end{array}$} \\
\hline & & & & Alpha & $\begin{array}{l}\text { Alpha } \\
\text { FSL }\end{array}$ & Beta & $\begin{array}{l}\text { Beta } \\
\text { FSL }\end{array}$ \\
\hline \multirow{6}{*}{5} & \multirow{6}{*}{ L } & \multirow{6}{*}{ AT28 } & $0-5$ & 97.4 & \multirow{6}{*}{89} & 11,200 & \multirow{6}{*}{4,171} \\
\hline & & & $5-10$ & 84.4 & & 14,600 & \\
\hline & & & 10-15 & 123 & & 14,700 & \\
\hline & & & $15-20$ & 84.4 & & 11,700 & \\
\hline & & & $20-25$ & 52 & & 8,016 & \\
\hline & & & $25-30$ & 26 & & 3,107 & \\
\hline \multirow{6}{*}{6} & \multirow{6}{*}{ M } & \multirow{6}{*}{ АТЗ } & $0-5$ & 45.5 & \multirow{6}{*}{89} & 2,989 & \multirow{6}{*}{4,171} \\
\hline & & & $5-10$ & 0 & & 2,878 & \\
\hline & & & 10-15 & 32.5 & & 2,772 & \\
\hline & & & $15-20$ & 0 & & 3,031 & \\
\hline & & & $20-25$ & 52 & & 3,126 & \\
\hline & & & $25-30$ & 32.5 & & 3,110 & \\
\hline
\end{tabular}

Note: Bolded values exceed screening boring criteria: $>$ FSL $\underline{\text { AND }}>20$ percent difference between each depth interval reading and surface sample reading.

$\mathrm{dpm} / 100 \mathrm{~cm}^{2}=$ Disintegrations per minute per 100 square centimeters

\section{A.3.2.1.2 Plutonium Ratios near the Uncle and Ess Craters}

During the evaluation of analytical data for the internal dose assessment, the alpha spectroscopic ratios of Am-241 to Pu-238 and Pu-239/240 to Am-241 were examined and compared to expected values for Hanford reference weapons-grade plutonium (PNNL, 2009). Sample plots K and L showed an unexpectedly high ratio of Pu-239/240 to Am-241. The laboratory data were inspected and validated, and results were recalculated for verification purposes. In addition, aliquots of the original subsurface soil samples from sample plots K and L were re-extracted and reanalyzed, yielding similar results (see Appendix F).

Because sample plots $\mathrm{K}$ and L are near the Uncle and Ess craters, information regarding the device composition was reviewed to ascertain whether factors unique to the Uncle or Ess test device could 
be the source of the high $\mathrm{Pu}-239-$ to-Am-241 ratios. It was determined that the differences in device composition were the only viable explanation for the unique ratios.

\section{A.3.2.2 External Dose Estimates}

Estimates of the external dose that a receptor would receive at each TLD location were derived from the results of TLD samples. The external dose for the Industrial Area scenario was calculated and then scaled (based on exposure duration) to the Remote Work Area and Occasional Use Area exposure scenarios for each TLD location. As shown in Table A.3-7, the TLD results at 24 TLD locations exceeded the PAL of 25 mrem/IA-year, but none exceeded the FAL under the Remote Work scenario. This indicates that regardless of the internal dose contribution at these locations, the external dose is the major contributor to TED.

Table A.3-7

External Dose Estimates (95 Percent UCL) at TLD Locations for Each Exposure Scenario

(Page 1 of 3 )

\begin{tabular}{|c|c|c|c|c|}
\hline Sample Plot & $\begin{array}{c}\text { TLD } \\
\text { Location }\end{array}$ & $\begin{array}{c}\text { Industrial Area } \\
\text { (mrem/IA-yr) }\end{array}$ & $\begin{array}{c}\text { Remote Work Area } \\
\text { (mrem/RW-yr) }\end{array}$ & $\begin{array}{c}\text { Occasional Use Area } \\
\text { (mrem/OU-yr) }\end{array}$ \\
\hline \hline A & AT42 & $\mathbf{6 1 . 8 2}$ & 9.23 & 2.20 \\
\hline B & AT41 & $\mathbf{3 4 . 8 7}$ & 5.21 & 1.24 \\
\hline C & AT44 & 17.50 & 2.61 & 0.62 \\
\hline D & AT45 & 15.59 & 2.33 & 0.55 \\
\hline E & AT33 & $\mathbf{5 9 . 0 4}$ & 8.82 & 2.10 \\
\hline F & AT34 & $\mathbf{7 0 . 3 6}$ & 10.51 & 2.50 \\
\hline G & AT36 & $\mathbf{3 8 . 0 1}$ & 5.68 & 1.35 \\
\hline H & AT39 & 13.41 & 2.00 & 0.48 \\
\hline J & AT24 & $\mathbf{5 7 . 2 9}$ & 8.56 & 2.04 \\
\hline K & AT55 & $\mathbf{9 3 . 9 6}$ & 14.03 & 3.34 \\
\hline L & AT28 & $\mathbf{7 7 . 7 1}$ & 11.61 & 2.76 \\
\hline M & AT30 & 7.31 & 1.09 & 0.26 \\
\hline N & AT01 & $\mathbf{4 9 . 6 5}$ & 7.42 & 1.77 \\
\hline P & AT02 & $\mathbf{2 9 . 2 8}$ & 4.37 & 1.04 \\
\hline Q & AT03 & 4.36 & 0.65 & 0.16 \\
\hline
\end{tabular}


Table A.3-7

\section{External Dose Estimates (95 Percent UCL) at TLD Locations for} Each Exposure Scenario

(Page 2 of 3 )

\begin{tabular}{|c|c|c|c|c|}
\hline Sample Plot & $\begin{array}{c}\text { TLD } \\
\text { Location }\end{array}$ & $\begin{array}{c}\text { Industrial Area } \\
\text { (mrem/IA-yr) }\end{array}$ & $\begin{array}{l}\text { Remote Work Area } \\
\text { (mrem/RW-yr) }\end{array}$ & $\begin{array}{l}\text { Occasional Use Area } \\
\text { (mrem/OU-yr) }\end{array}$ \\
\hline $\mathrm{R}$ & AT05 & 21.88 & 3.27 & 0.78 \\
\hline No plot & AT04 & 7.52 & 1.12 & 0.27 \\
\hline No plot & AT06 & 23.25 & 3.47 & 0.83 \\
\hline No plot & AT07 & 11.16 & 1.67 & 0.40 \\
\hline No plot & AT08 & 4.87 & 0.73 & 0.17 \\
\hline No plot & AT09 & 11.66 & 1.74 & 0.41 \\
\hline No plot & AT10 & 33.90 & 5.06 & 1.21 \\
\hline No plot & AT11 & 26.48 & 3.95 & 0.94 \\
\hline No plot & AT12 & 29.69 & 4.43 & 1.06 \\
\hline No plot & AT13 & 17.29 & 2.58 & 0.61 \\
\hline No plot & AT14 & 9.99 & 1.49 & 0.36 \\
\hline No plot & AT15 & 1.98 & 0.30 & 0.07 \\
\hline No plot & AT16 & 8.72 & 1.30 & 0.31 \\
\hline No plot & AT17 & 6.03 & 0.90 & 0.21 \\
\hline No plot & AT18 & 12.43 & 1.86 & 0.44 \\
\hline No plot & AT19 & 3.55 & 0.53 & 0.13 \\
\hline No plot & AT20 & 25.62 & 3.83 & 0.91 \\
\hline No plot & AT21 & 29.23 & 4.36 & 1.04 \\
\hline No plot & AT22 & 19.49 & 2.91 & 0.69 \\
\hline No plot & AT23 & 15.02 & 2.24 & 0.53 \\
\hline No plot & AT25 & 50.20 & 7.50 & 1.78 \\
\hline No plot & AT26 & 51.29 & 7.66 & 1.82 \\
\hline No plot & AT27 & 7.17 & 1.07 & 0.25 \\
\hline No plot & AT29 & 55.08 & 8.23 & 1.96 \\
\hline No plot & AT31 & 21.07 & 3.15 & 0.75 \\
\hline No plot & AT32 & 9.14 & 1.37 & 0.33 \\
\hline No plot & AT35 & 50.15 & 7.49 & 1.78 \\
\hline No plot & AT37 & 34.45 & 5.14 & 1.22 \\
\hline
\end{tabular}


Table A.3-7

\section{External Dose Estimates (95 Percent UCL) at TLD Locations for Each Exposure Scenario}

(Page 3 of 3 )

\begin{tabular}{||c|c|c|c|c||}
\hline Sample Plot & $\begin{array}{c}\text { TLD } \\
\text { Location }\end{array}$ & $\begin{array}{c}\text { Industrial Area } \\
\text { (mrem/IA-yr) }\end{array}$ & $\begin{array}{c}\text { Remote Work Area } \\
\text { (mrem/RW-yr) }\end{array}$ & $\begin{array}{c}\text { Occasional Use Area } \\
\text { (mrem/OU-yr) }\end{array}$ \\
\hline \hline No plot & AT38 & $\mathbf{3 0 . 4 0}$ & 4.54 & 1.08 \\
\hline No plot & AT40 & 11.44 & 1.71 & 0.41 \\
\hline No plot & AT43 & $\mathbf{3 0 . 4 1}$ & 4.54 & 1.08 \\
\hline No plot & AT46 & 10.69 & 1.60 & 0.38 \\
\hline No plot & AT47 & 14.41 & 2.15 & 0.51 \\
\hline No plot & AT48 & 9.33 & 1.39 & 0.33 \\
\hline No plot & AT49 & $\mathbf{2 8 . 0 6}$ & 4.19 & 1.00 \\
\hline No plot & AT50 & 17.94 & 2.68 & 0.64 \\
\hline No plot & AT51 & $\mathbf{5 6 . 9 3}$ & 8.50 & 2.02 \\
\hline No plot & AT53 & 2.72 & 0.41 & 0.10 \\
\hline No plot & AT54 & 2.95 & 0.44 & 0.10 \\
\hline No plot & AT56 & $0^{\text {a }}$ & $0^{\text {a }}$ & $0^{\text {a }}$ \\
\hline No plot & AT57 & 5.95 & 0.89 & 0.21 \\
\hline No plot & AT59 & $0^{\text {a }}$ & $0^{a}$ & $0^{\text {a }}$ \\
\hline \hline
\end{tabular}

${ }^{a}$ Negative values have been replaced with zero. A negative value indicates the TLD reading was less than the representative field background value.

Note: Bold indicates the value is greater than the FAL (25 mrem/yr). Dose values have been rounded to three significant digits. 


\section{A.3.2.3 Total Effective Dose}

The TED represents the sum of the internal dose (from sample plot data) and the external dose (from the TLDs). The TED results are compared to the PAL of $25 \mathrm{mrem} / \mathrm{IA}-\mathrm{yr}$ and the FAL of 25 mrem/RW-yr. The PALs were established in the CAIP and are based on the annual exposure duration of the Industrial Area scenario (2,250 hr/yr). The 95 percent UCL TED exceeded the PALs at 24 locations (see Table A.3-9).

The FALs are based on the annual exposure duration of the Remote Work Area scenario (336 hr/yr), as detailed in Appendix C. Under this exposure scenario, the 95 percent UCL TED for surface soils did not exceed the FAL of 25 mrem/RW-yr at any sample location (Figure A.3-6). The CAU 367 surface location at which the maximum dose was measured was sample plot $\mathrm{K}$ on the south vector between the Uncle and Ess craters. A receptor would have to be exposed to this location for 621 hours to receive a dose of 25 mrem.

As shown in Table A.3-8, the percent contribution to TED from internal dose is small. At the location of the highest average internal dose (sample plot $\mathrm{G}$ located on the east vector), the internal dose contribution was 6.72 percent of the TED. The maximum percent contribution of internal dose was 7 percent at sample plot R located on the northwest vector near Circle Road.

Values for both the average TED and the 95 percent UCL of the average TED for the Industrial Area, Remote Work Area, and Occasional Use Area exposure scenarios are presented in Table A.3-9.

Considering only radioactive decay mechanisms (ignoring contamination erosion and transport mechanisms), dose at the location of the maximum average TED will decay from 90.6 to 25 mrem/IA-yr in about 69.6 years. The effective half-life is about 34.7 years and is driven by cesium (Cs)-137, which contributes about 94 percent of the external dose at the site. 
Table A.3-8

Ratio of Internal Dose to External Dose at Sample Plots (mrem/IA-yr)

\begin{tabular}{||c|c|c|c|c|c|}
\hline $\begin{array}{c}\text { Sample } \\
\text { Plot }\end{array}$ & $\begin{array}{c}\text { Average } \\
\text { Internal }\end{array}$ & $\begin{array}{c}\text { Average } \\
\text { External }\end{array}$ & $\begin{array}{c}\text { Average } \\
\text { Total }\end{array}$ & $\begin{array}{c}\text { Percent } \\
\text { Internal }\end{array}$ & $\begin{array}{c}\text { Percent } \\
\text { External }\end{array}$ \\
\hline \hline $\mathrm{A}$ & 1.43 & 51.9 & 53.3 & 2.68 & 97.32 \\
\hline $\mathrm{B}$ & 0.539 & 33.5 & 34 & 1.59 & 98.41 \\
\hline $\mathrm{C}$ & 0.625 & 14.7 & 15.3 & 4.09 & 95.91 \\
\hline $\mathrm{D}$ & 0.474 & 12 & 12.5 & 3.81 & 96.19 \\
\hline $\mathrm{E}$ & 1.83 & 55.5 & 57.4 & 3.18 & 96.82 \\
\hline $\mathrm{F}$ & 2.18 & 62.4 & 64.5 & 3.37 & 96.63 \\
\hline $\mathrm{G}$ & 2.40 & 33.3 & 35.7 & 6.72 & 93.28 \\
\hline $\mathrm{H}$ & 0.652 & 9.94 & 10.6 & 6.16 & 93.84 \\
\hline $\mathrm{J}$ & 0.924 & 53.8 & 54.7 & 1.69 & 98.31 \\
\hline $\mathrm{K}$ & 1.26 & 89.3 & 90.6 & 1.39 & 98.61 \\
\hline $\mathrm{L}$ & 0.517 & 67.3 & 67.8 & 0.76 & 99.24 \\
\hline $\mathrm{M}$ & 0.028 & 3.64 & 3.67 & 0.76 & 99.24 \\
\hline $\mathrm{N}$ & 1.35 & 39.2 & 40.5 & 3.33 & 96.67 \\
\hline $\mathrm{P}$ & 0.738 & 26.1 & 26.8 & 2.76 & 97.24 \\
\hline $\mathrm{Q}$ & 0.069 & $0^{\mathrm{a}}$ & $00^{\mathrm{a}}$ & $0^{\mathrm{a}}$ & $0^{\mathrm{a}}$ \\
\hline $\mathrm{R}$ & 1.52 & 20.3 & 21.8 & 7 & 93 \\
\hline
\end{tabular}

${ }^{a}$ The net average external dose and average total dose at sample plot $Q$ were negative values, because the external dose value was less than the field background value. Therefore, the percentages of internal and external dose were not calculated for this plot.

Note: Dose values have been rounded to three significant digits. 
Table A.3-9

Total Effective Dose at Primary Release Sample Locations (mrem/yr) (Page 1 of 3 )

\begin{tabular}{|c|c|c|c|c|c|c|c|}
\hline \multirow{2}{*}{$\begin{array}{l}\text { Sample } \\
\text { Plot }\end{array}$} & \multirow{2}{*}{$\begin{array}{c}\text { TLD } \\
\text { Location }\end{array}$} & \multicolumn{2}{|c|}{ Industrial Area } & \multicolumn{2}{|c|}{ Remote Work Area } & \multicolumn{2}{|c|}{ Occasional Use Area } \\
\hline & & $\begin{array}{l}\text { Average } \\
\text { Total }\end{array}$ & $\begin{array}{c}\text { 95\% UCL } \\
\text { Total }\end{array}$ & $\begin{array}{l}\text { Average } \\
\text { Total }\end{array}$ & $\begin{array}{c}\text { 95\% UCL } \\
\text { Total }\end{array}$ & $\begin{array}{c}\text { Average } \\
\text { Total }\end{array}$ & $\begin{array}{c}\text { 95\% UCL } \\
\text { Total }\end{array}$ \\
\hline$A$ & AT42 & 53.3 & 63.4 & 7.99 & 9.51 & 1.93 & 2.30 \\
\hline B & AT41 & 34 & 35.5 & 5.09 & 5.32 & 1.22 & 1.28 \\
\hline $\mathrm{C}$ & AT44 & 15.3 & 18.2 & 2.30 & 2.73 & 0.560 & 0.662 \\
\hline $\mathrm{D}$ & AT45 & 12.5 & 16.1 & 1.87 & 2.42 & 0.455 & 0.585 \\
\hline$E$ & AT33 & 57.4 & 61 & 8.61 & 9.15 & 2.09 & 2.22 \\
\hline$F$ & AT34 & 64.5 & 72.7 & 9.69 & 10.9 & 2.35 & 2.65 \\
\hline G & AT36 & 35.7 & 40.7 & 5.39 & 6.14 & 1.33 & 1.52 \\
\hline $\mathrm{H}$ & AT39 & 10.6 & 14.3 & 1.60 & 2.16 & 0.393 & 0.531 \\
\hline $\mathrm{J}$ & AT24 & 54.7 & 58.3 & 8.19 & 8.73 & 1.97 & 2.10 \\
\hline $\mathrm{K}$ & AT55 & 90.6 & 95.5 & 13.6 & 14.3 & 3.25 & 3.44 \\
\hline $\mathrm{L}$ & AT28 & 67.8 & 78.4 & 10.1 & 11.7 & 2.42 & 2.80 \\
\hline $\mathrm{M}$ & AT30 & 3.66 & 7.36 & 0.548 & 1.1 & 0.131 & 0.263 \\
\hline $\mathrm{N}$ & AT01 & 40.5 & 51.1 & 6.08 & 7.67 & 1.48 & 1.86 \\
\hline $\mathrm{P}$ & AT02 & 26.8 & 30.1 & 4.02 & 4.51 & 0.971 & 1.09 \\
\hline $\mathrm{Q}$ & AT03 & $0^{a}$ & 4.46 & $0^{a}$ & 0.669 & $0^{a}$ & 0.161 \\
\hline $\mathrm{R}$ & AT05 & 21.8 & 23.7 & 3.29 & 3.59 & 0.814 & 0.892 \\
\hline No plot & AT04 & 3.06 & 8.05 & 0.461 & 1.22 & 0.114 & 0.30 \\
\hline No plot & AT06 & 13.6 & 24.9 & 2.05 & 3.76 & 0.506 & 0.927 \\
\hline No plot & AT07 & 8.34 & 11.9 & 1.26 & 1.8 & 0.311 & 0.445 \\
\hline No plot & AT08 & 0.195 & 5.22 & 0.030 & 0.787 & 0.007 & 0.194 \\
\hline No plot & AT09 & 10.5 & 12.5 & 1.58 & 1.88 & 0.391 & 0.465 \\
\hline No plot & AT10 & 26.6 & 36.3 & 4.02 & 5.48 & 0.994 & 1.35 \\
\hline No plot & AT11 & 24.7 & 28.3 & 3.72 & 4.28 & 0.92 & 1.06 \\
\hline No plot & AT12 & 27.1 & 31.8 & 4.09 & 4.8 & 1.01 & 1.18 \\
\hline No plot & AT13 & 17.7 & 18.5 & 2.68 & 2.79 & 0.661 & 0.690 \\
\hline No plot & AT14 & 9.65 & 10.7 & 1.46 & 1.61 & 0.360 & 0.398 \\
\hline No plot & AT15 & $0^{a}$ & 2.12 & $0^{a}$ & 0.32 & $0^{a}$ & 0.079 \\
\hline
\end{tabular}


Table A.3-9

Total Effective Dose at Primary Release Sample Locations (mrem/yr) (Page 2 of 3 )

\begin{tabular}{|c|c|c|c|c|c|c|c|}
\hline \multirow{2}{*}{$\begin{array}{l}\text { Sample } \\
\text { Plot }\end{array}$} & \multirow{2}{*}{$\begin{array}{c}\text { TLD } \\
\text { Location }\end{array}$} & \multicolumn{2}{|c|}{ Industrial Area } & \multicolumn{2}{|c|}{ Remote Work Area } & \multicolumn{2}{|c|}{ Occasional Use Area } \\
\hline & & $\begin{array}{l}\text { Average } \\
\text { Total }\end{array}$ & $\begin{array}{c}95 \% \text { UCL } \\
\text { Total }\end{array}$ & $\begin{array}{l}\text { Average } \\
\text { Total }\end{array}$ & $\begin{array}{c}95 \% \text { UCL } \\
\text { Total }\end{array}$ & $\begin{array}{c}\text { Average } \\
\text { Total }\end{array}$ & $\begin{array}{c}95 \% \text { UCL } \\
\text { Total }\end{array}$ \\
\hline No plot & AT16 & 3.81 & 9.34 & 0.576 & 1.41 & 0.142 & 0.348 \\
\hline No plot & AT17 & 4.33 & 6.45 & 0.654 & 0.974 & 0.162 & 0.240 \\
\hline No plot & AT18 & 10.2 & 13.3 & 1.55 & 2.01 & 0.382 & 0.496 \\
\hline No plot & AT19 & 1.32 & 3.8 & 0.199 & 0.574 & 0.049 & 0.142 \\
\hline No plot & AT20 & 25.5 & 27.4 & 3.86 & 4.14 & 0.953 & 1.02 \\
\hline No plot & AT21 & 25.6 & 31.3 & 3.87 & 4.72 & 0.955 & 1.17 \\
\hline No plot & AT22 & 18.1 & 20.9 & 2.73 & 3.15 & 0.673 & 0.777 \\
\hline No plot & AT23 & 9.92 & 16.1 & 1.50 & 2.43 & 0.37 & 0.599 \\
\hline No plot & AT25 & 50.1 & 53.7 & 7.57 & 8.11 & 1.87 & 2.00 \\
\hline No plot & AT26 & 52.8 & 54.9 & 7.97 & 8.29 & 1.97 & 2.05 \\
\hline No plot & AT27 & 5.25 & 7.67 & 0.793 & 1.16 & 0.196 & 0.286 \\
\hline No plot & AT29 & 54.8 & 59 & 8.28 & 8.9 & 2.05 & 2.20 \\
\hline No plot & AT31 & 18.3 & 22.5 & 2.76 & 3.4 & 0.681 & 0.840 \\
\hline No plot & AT32 & 8.30 & 9.79 & 1.25 & 1.48 & 0.310 & 0.365 \\
\hline No plot & AT35 & 50.3 & 53.7 & 7.60 & 8.1 & 1.88 & 2.00 \\
\hline No plot & AT37 & 28.6 & 36.9 & 4.33 & 5.57 & 1.07 & 1.37 \\
\hline No plot & AT38 & 22.0 & 32.5 & 3.33 & 4.91 & 0.822 & 1.21 \\
\hline No plot & AT40 & 8.54 & 12.2 & 1.29 & 1.85 & 0.319 & 0.456 \\
\hline No plot & AT43 & 27.9 & 32.6 & 4.22 & 4.91 & 1.04 & 1.21 \\
\hline No plot & AT46 & 9.61 & 11.4 & 1.45 & 1.73 & 0.359 & 0.427 \\
\hline No plot & AT47 & 12.2 & 15.4 & 1.84 & 2.33 & 0.455 & 0.575 \\
\hline No plot & AT48 & 7.67 & 9.98 & 1.16 & 1.51 & 0.286 & 0.372 \\
\hline No plot & AT49 & 26.3 & 30 & 3.97 & 4.53 & 0.981 & 1.12 \\
\hline No plot & AT50 & 14.8 & 19.2 & 2.23 & 2.9 & 0.552 & 0.716 \\
\hline No plot & AT51 & 49.8 & 60.9 & 7.52 & 9.2 & 1.86 & 2.27 \\
\hline No plot & AT53 & $0^{\mathrm{a}}$ & 2.91 & $0^{\mathrm{a}}$ & 0.439 & $0^{a}$ & 0.108 \\
\hline No plot & AT54 & 0.748 & 3.16 & 0.113 & 0.477 & 0.028 & 0.118 \\
\hline
\end{tabular}


Table A.3-9

\section{Total Effective Dose at Primary Release Sample Locations (mrem/yr)}

(Page 3 of 3 )

\begin{tabular}{|c|c|c|c|c|c|c|c||}
\hline \multirow{2}{*}{$\begin{array}{c}\text { Sample } \\
\text { Plot }\end{array}$} & TLD & \multicolumn{2}{|c|}{ Industrial Area } & \multicolumn{2}{c|}{ Remote Work Area } & \multicolumn{2}{c||}{ Occasional Use Area } \\
\cline { 3 - 8 } & Location & $\begin{array}{c}\text { Average } \\
\text { Total }\end{array}$ & $\begin{array}{c}95 \% \text { UCL } \\
\text { Total }\end{array}$ & $\begin{array}{c}\text { Average } \\
\text { Total }\end{array}$ & $\begin{array}{c}\text { 95\% UCL } \\
\text { Total }\end{array}$ & $\begin{array}{c}\text { Average } \\
\text { Total }\end{array}$ & $\begin{array}{c}\text { 95\% UCL } \\
\text { Total }\end{array}$ \\
\hline \hline No plot & AT56 & $0^{\mathrm{a}}$ & $0^{\mathrm{a}}$ & $0^{\mathrm{a}}$ & $0^{\mathrm{a}}$ & $0^{\mathrm{a}}$ & $0^{\mathrm{a}}$ \\
\hline No plot & AT57 & 4.65 & 6.37 & 0.702 & 0.962 & 0.173 & 0.237 \\
\hline No plot & AT59 & $0^{\mathrm{a}}$ & $0^{\mathrm{a}}$ & $0^{\mathrm{a}}$ & $0^{\mathrm{a}}$ & $0^{\mathrm{a}}$ & $0^{\mathrm{a}}$ \\
\hline
\end{tabular}

${ }^{a}$ Negative values have been replaced with zero. A negative value indicates the TLD reading was less than the representative field background value.

Note: Bold indicates the value is greater than the FAL (25 mrem/yr).

Values have been rounded to three significant digits.

\section{A.3.3 Nature and Extent of Contamination}

Based on the evaluation of dose using the Remote Work Area exposure scenario, the FAL is not exceeded at any sample location (Figure A.3-6). As a result, no COCs were identified at any of the three crater CASs outside the default contamination boundary. Due to direct injection of radionuclides into the subsurface soil from the nuclear tests, however, it is assumed that subsurface contamination exceeding the FAL is present within each crater and the surrounding ejecta mounds. This assumption was based on knowledge of the three tests which suggests that much of the radioactivity associated with the tests was captured within the craters and in fractures around the craters (i.e., prompt injection). Therefore, a corrective action of closure in place with a UR was implemented at each crater CAS to account for the subsurface contamination. The URs apply within established boundaries (FFACO UR boundaries) that each encircle the default contamination boundaries (Figure A.3-6). The default contamination boundaries were defined in the CAIP for each crater CAS as the area of the crater, crater rim, and related mounding around the crater. The default contamination boundary at each of the three crater CASs at CAU 367 was determined through a ground-based visual survey of the ejecta mounds surrounding the crater.

The TED values for the crater CASs were also compared to the PAL of 25 mrem/IA-yr established in the CAIP. As indicated in Figure A.3-7 and Table A.3-9, the PAL is exceeded at 24 sample locations. As a BMP, an administrative UR was established to include any area where an industrial land use of 


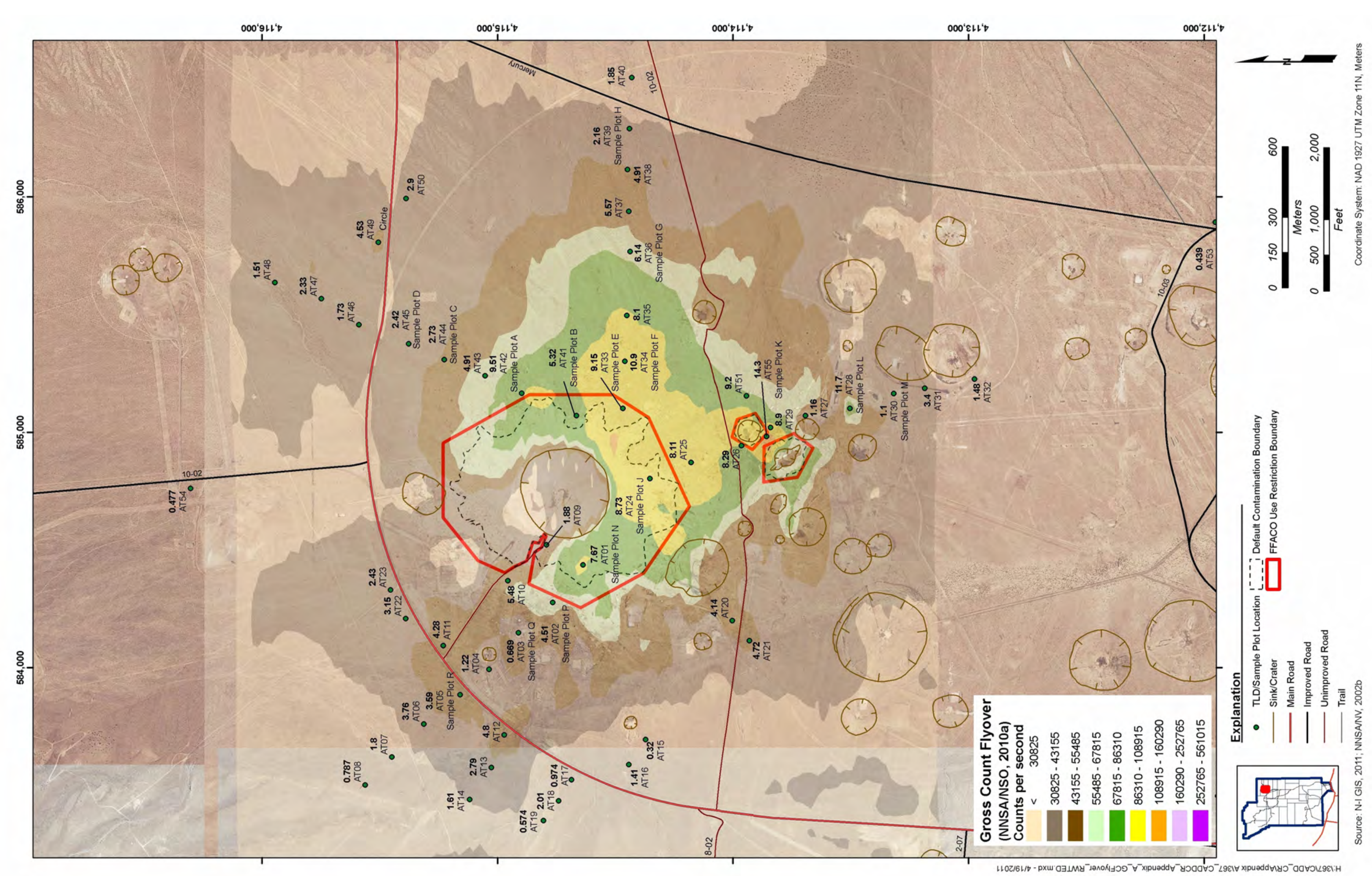

Figure A.3-6

Total Effective Dose (95 Percent UCL) for Remote Work Area Scenario (mrem/RW-yr) 
the area (2,250 hr/yr) could cause a future site worker to receive a dose exceeding $25 \mathrm{mrem} / \mathrm{yr}$. To determine the extent of this area, a correlation of the 95 percent UCL for the Industrial Area scenario was plotted against each of the following datasets:

- Ground-based large area transect radiological surveys obtained in October 2010

- Aerial radiological surveys (gross count) obtained in November 2009

- Aerial radiological surveys (man-made) obtained in November 2009

- Aerial radiological surveys (americium) obtained in November 2009

Each of the datasets was converted from point data into a continuous dataset (surface) by using an inverse distance weighted interpolation method. The continuous dataset was then used to determine values at each TLD location. The relationship between the surface value and the 95 percent UCL TED for the Industrial Area exposure scenario was determined by statistical correlation.

The correlation coefficient ( $\mathrm{R}^{2}$ value) indicates the strength of the correlation. The $\mathrm{R}^{2}$ values for the correlations were $0.883,0.880,0.836$, and 0.004 , respectively. Generally, the closer the correlation coefficient is to 1.0, the stronger the correlation is between the datasets. Because the correlation of TED data to the ground-based radiological survey data was the strongest, these data were used to create an interpolated surface represented by the multicolored isopleths in Figure A.3-8. The 95 percent UCL of the TED from each sample location was then correlated to the interpolated surface. Based on this correlation, the value that corresponds to $25 \mathrm{mrem} / \mathrm{IA}-\mathrm{yr}$ is 1.94 multiples of background. The solid green line in Figure A.3-8 represents the estimated 25-mrem/IA-yr boundary (i.e., the boundary within which a receptor can expect to receive a radiological dose in excess of $25 \mathrm{mrem} / \mathrm{yr}$ in the Industrial Area exposure scenario). This boundary is derived from a continuous interpolated surface and therefore may cross areas that were not surveyed (e.g., the Sedan crater). The administrative UR boundary was conservatively drawn to encompass all areas greater than 1,000 $\mathrm{m}^{2}$ with a TED greater than 25 mrem/IA-yr (Figure A.3-8). Although the TED at TLD location AT49 was 30 mrem/IA-yr, it was not included in the administrative UR boundary, because the estimated area exceeding 25 mrem/IA-yr was less than 1,000 $\mathrm{m}^{2}$. The administrative UR boundary is presented in Attachment D-2. 


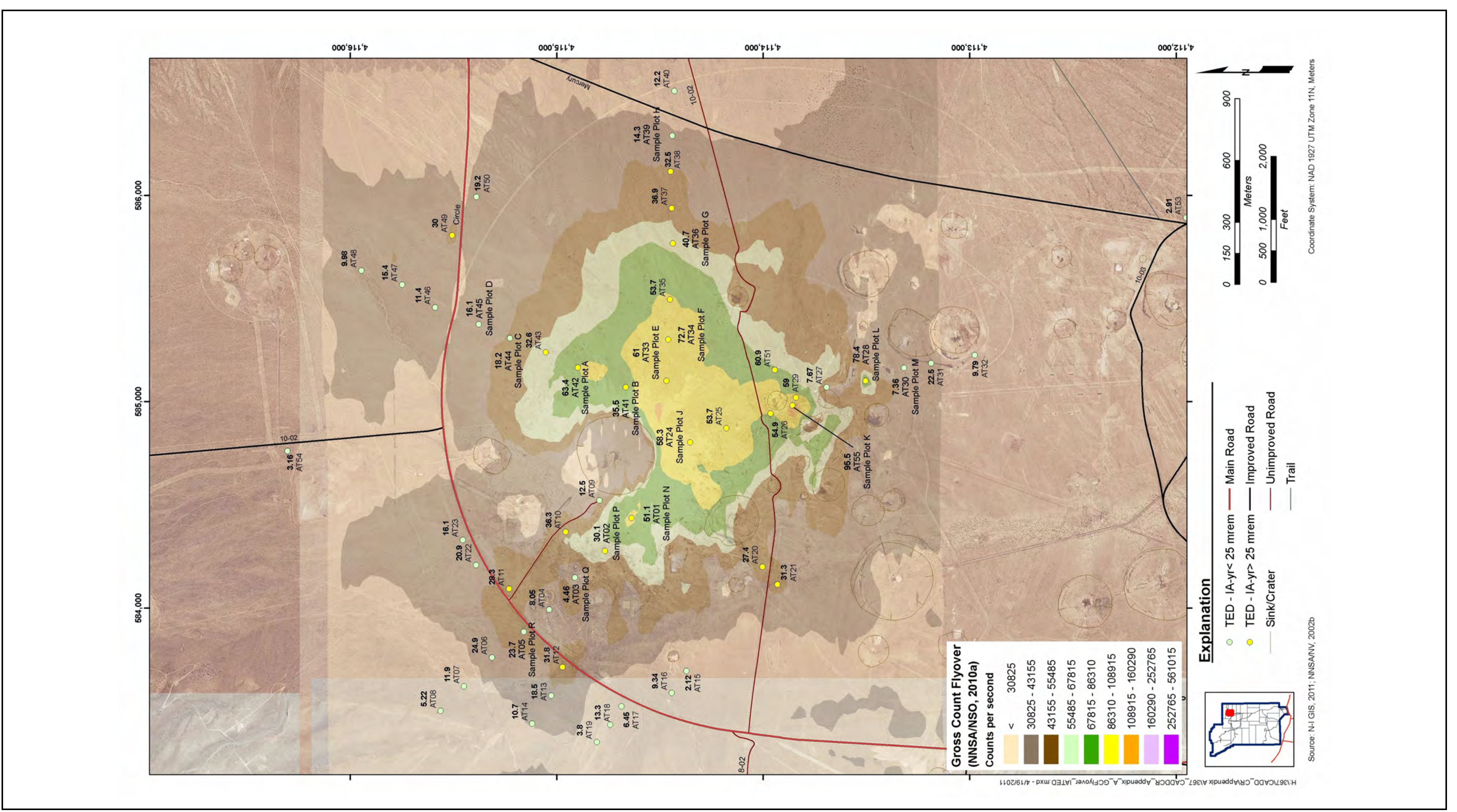

Total Effective Dose (95 Percent UCL) for Industrial Use Area Scenario (mrem/IA-yr) 


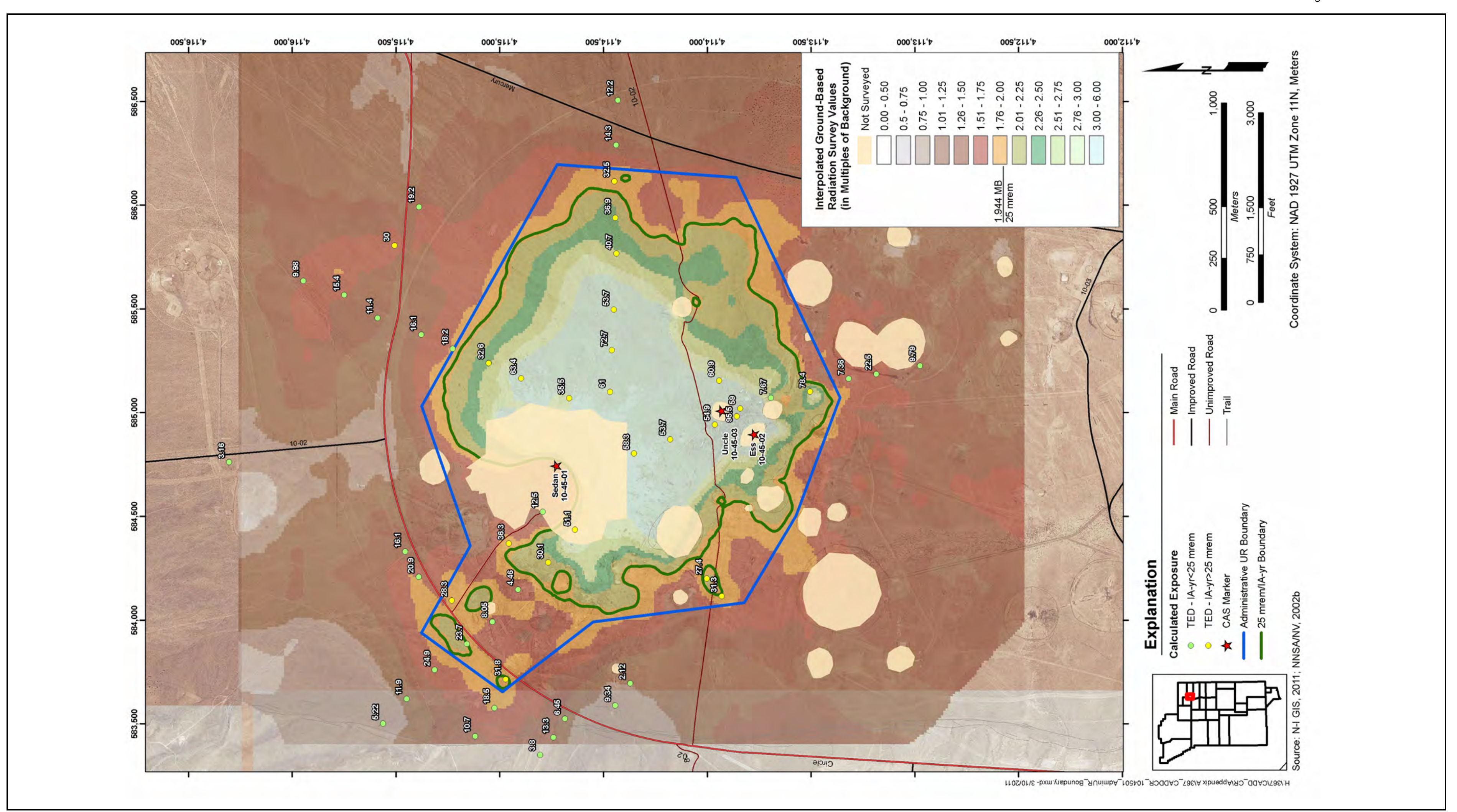

Figure A.3-8

Administrative Use Restriction Boundary 


\section{A.3.4 Revised Conceptual Site Model}

The CAIP requirements were met at the three crater CASs. The information gathered during the CAI supports the CSM as presented in the CAIP for CAU 367. Therefore, no revisions were necessary to the CSM. 


\section{A.4.0 Other Releases}

Three specific site features requiring investigation were identified as other releases in the CAIP:

- Sediment accumulation areas within site drainages

- An area along the shoulder of Circle Road northwest of the Sedan crater

- CAS 10-09-03, Mud Pit

In addition to these specific features, several debris items were investigated as other releases. At other release locations, sampling was based on biasing factors such as radiological surveys and visual observation.

\section{A.4.1 Drainages}

The CAIP called for surveying the nearest surface drainage feature located east of the Sedan crater for the presence of sedimentation areas as part of the CAU 367 investigation. The visual survey of this area concluded that surface water flowing east of the Sedan crater in a southwesterly direction would most likely drain into the U-10u subsidence crater located south of the Sedan crater (Figure A.4-1). No evidence (e.g., erosion) of surface water flow into or out of the U-10u crater and no areas of sedimentation were observed. The survey did not identify any drainage features or associated sedimentation areas, and as a result, no sampling of drainage features was conducted during the CAI.

\section{A.4.2 Mercury Highway/Circle Road}

An area along Circle Road (referred to as Mercury Highway in the CAIP) was identified as a potential other release in the CAIP based on the 1994 aerial survey of CAU 367 (BN, 1999). This survey suggested an area of elevated radioactivity in the region northwest of the Sedan crater. The 2009 aerial survey confirmed the results of the earlier survey (NNSA/NSO, 2010a). The northwest portion of Circle Road was investigated to address the potential for exposure of motorists stopped on the roadside or site workers conducting road maintenance.

\section{A.4.2.1 Corrective Action Investigation Activities}

The 2009 aerial survey was reviewed to determine potential sample locations along Circle Road. Two judgmental sampling locations were selected based on a detailed ground-based radiological 


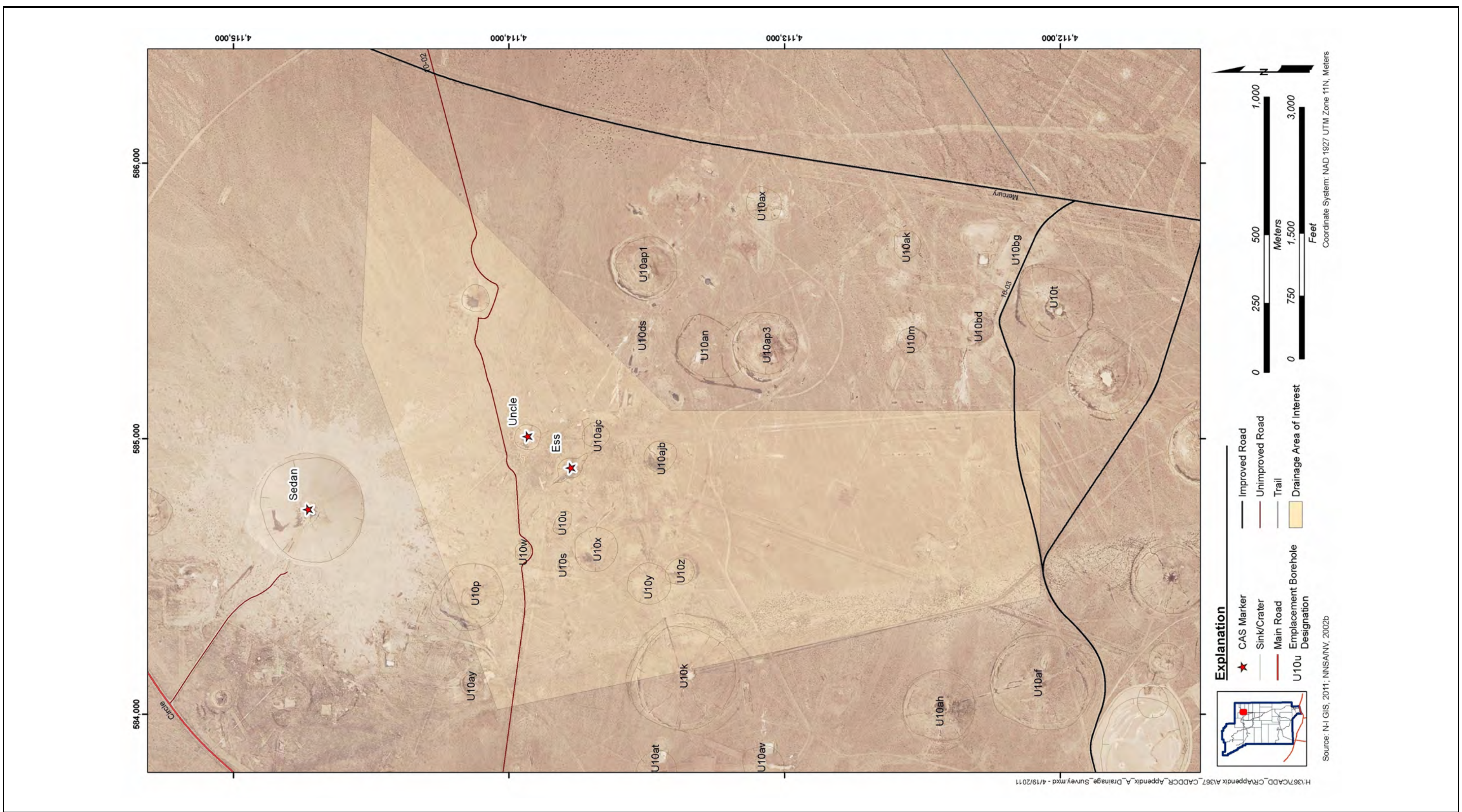

Figure A.4-1 
survey of the area. This survey was conducted using a PRM-470 instrument, and the results are shown in Figure A.4-2.

The selected sample locations (XH01 and XH02) are on the north side of Circle Road, northwest of the Sedan crater (Figure A.4-2). At each location, a 30-cm soil boring was collected and field screened for radioactivity in 5-cm depth increments (Section A.2.2.3). The depth interval with the highest reading was selected for laboratory analyses. At sample location XH01, the interval of 5 to10 cm was selected; at location XH02, the interval of 10 to $15 \mathrm{~cm}$ was selected. In accordance with the CAIP, the two grab soil samples were analyzed for the same analyses as the primary release: gamma spectroscopy, Sr-90, and isotopic U, Pu, and Am.

\section{A.4.2.2 Results}

Estimates of the internal dose that a receptor would receive at the Circle Road sample locations were determined as described in Section A.2.2.5. Because TLDs were not installed at the two grab sample locations, the external dose was calculated using RESRAD Version 6.5 and factored into the RRMG calculation. The TED at the two sample locations, XH01 and XH02, are 11.9 and 17.8 mrem/IA-yr, respectively. Thus, neither sampling location presents a dose rate greater than the PAL of $25 \mathrm{mrem} / \mathrm{yr}$ under the Industrial Area exposure scenario.

\section{A.4.2.3 Deviations}

Table A.4-1 describes the deviations from planned activities associated with the investigation of the other releases at CAU 367. The CAIP stated that the Circle Road sampling locations would be refined using a FIDLER instrument (or equivalent) to determine the location of highest radioactivity. As discussed in Section A.3.1.2.3, experience with the FIDLER instrument along the east vector at CAU 367 suggested that the instrument was not sensitive to Am-241 in the presence of a strong gamma signature, as is the case at CAU 367. Thus, at the Circle Road sample locations, the FIDLER instrument would have been recording the gamma signature rather than the presence of Am-241. As such, the FIDLER scan readings were not used to refine the sample locations at Circle Road. Instead, a radiological survey of the area was conducted using the PRM-470 instrument. The results of this survey and the results of the 2009 aerial survey were used to locate the two areas with the highest radiological readings, and samples were collected at these locations. In addition, the area most likely 


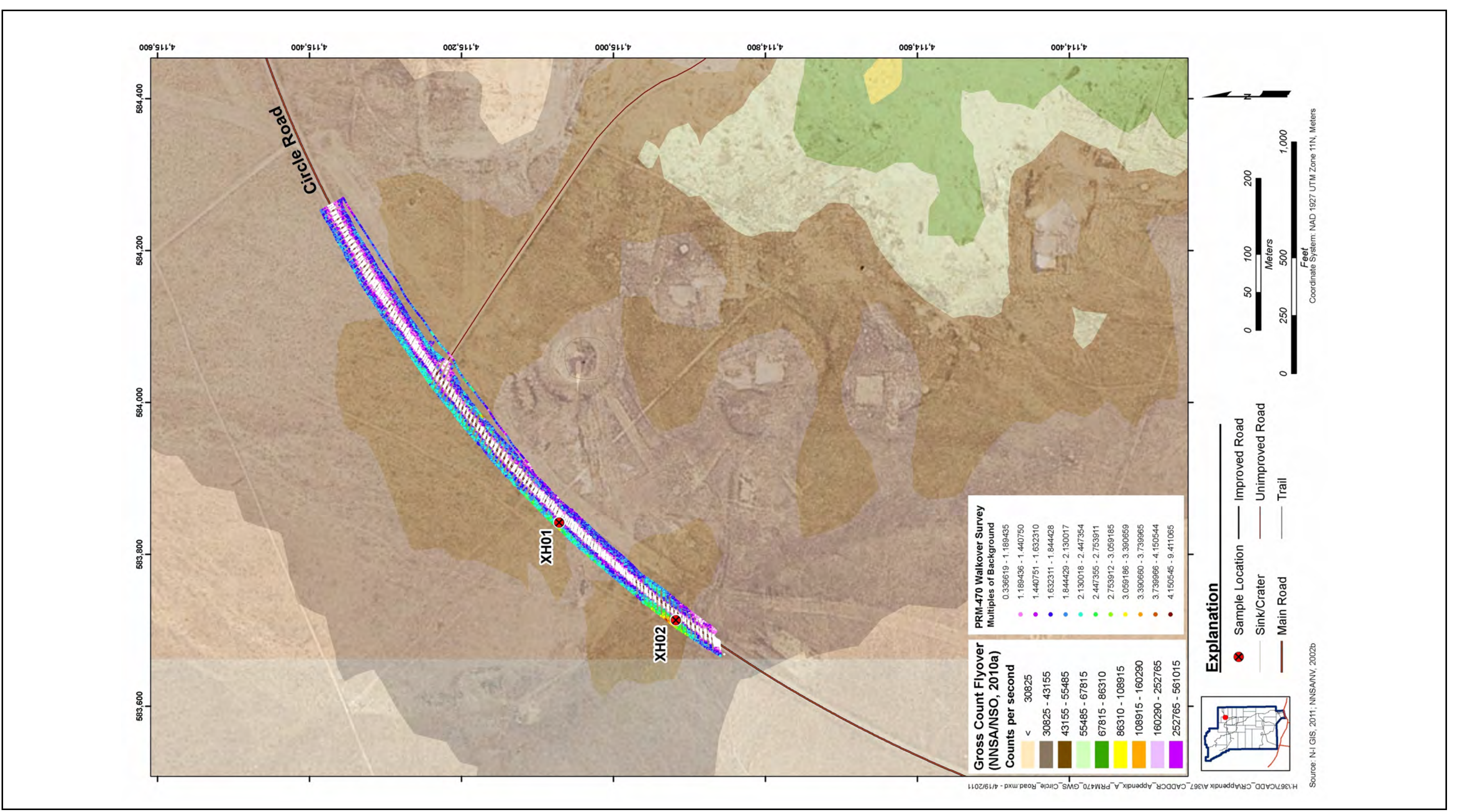

Figure A.4-2

Radiological Survey Results (Circle Road) 
to be graded as part of road maintenance was considered in determining the biased sample locations at Circle Road. This deviation did not adversely impact the CAI or the resolution of DQOs for CAU 367.

\section{A.4.2.4 Summary}

The calculated dose at the two subsurface sample locations along the shoulder of Circle Road is below the PAL of 25 mrem/IA-yr. Thus, no further action is recommended at these two sample locations.

\section{A.4.3 CAS 10-09-03, Mud Pit}

Corrective Action Site 10-09-03 consists of two mud pits: the Ess mud pit and the Akbar mud pit. The Ess mud pit was identified in the CAIP and is located at the bottom of the Ess crater. This mud pit consists of a release of bentonite clay material presumably used in post-test drilling operations associated with the Ess test (DOE, 1990). The Ess mud pit is categorized as a LANL post-test mud pit in accordance with the Mud Pit Risk-Based Closure Strategy Report (NNSA/NSO, 2004). The Akbar mud pit was identified during visual surveys of CAU 367 conducted during the CAI. This mud pit is located approximately 1,200 m southeast of the Ess mud pit. This mud pit consists of a release of bentonite clay material deposited when the U-10ax emplacement borehole was being drilled in support of the Akbar test (the test was conducted in 1972). The Akbar mud pit is categorized as a LLNL pretest mud pit in accordance with the Mud Pit Risk-Based Closure Strategy Report (NNSA/NSO, 2004).

\section{A.4.3.1 Corrective Action Investigation Activities}

Investigation activities at the Ess mud pit were limited to the collection of grab samples of the mud material. One surface environmental sample (0 to $15 \mathrm{~cm}$ bgs) and one field duplicate (FD) were collected at location XM01 within the mud pit (Figure A.4-3). In accordance with the CAU 367 CAIP, the samples were analyzed for volatile organic compounds (VOCs), semivolatile organic compounds (SVOCs), and gamma spectroscopy.

Corrective action investigation activities at the Akbar mud pit included a visual survey of the location and the collection of GPS coordinates. No samples were collected at the Akbar mud pit. 
Table A.4-1

Deviations from CAIP: Other Releases

\begin{tabular}{|c|c|c|c|}
\hline CAIP Section & Description & Deviation & Potential Adverse Impact on CAI \\
\hline $\begin{array}{l}\text { A.9.4.1.3, } \\
\text { Mercury Highway } \\
\text { (Circle Road) }\end{array}$ & $\begin{array}{l}\text { "At each area, the sampling location } \\
\text { will be further refined using a } \\
\text { FIDLER (or equivalent) radiation } \\
\text { survey instrument to determine the } \\
\text { location of highest radioactivity." }\end{array}$ & $\begin{array}{l}\text { The two sample locations were selected } \\
\text { based on the } 2009 \text { Am- } 241 \text { flyover data and } \\
\text { ground-based radiological surveys conducted } \\
\text { with the PRM- } 470 \text { instrument. A FIDLER } \\
\text { scan of the two areas was completed prior to } \\
\text { sampling; however, the location of highest } \\
\text { radioactivity at each area was not selected for } \\
\text { sampling due to high-energy gamma } \\
\text { interference (see Section A.3.1.2.3). }\end{array}$ & $\begin{array}{l}\text { None. The purpose of sample collection } \\
\text { along Circle Road was to determine the dose } \\
\text { to site workers during road maintenance. By } \\
\text { considering other biasing factors such as the } \\
\text { probable exposure scenarios, the evaluation of } \\
\text { risk was more specific to the site. }\end{array}$ \\
\hline $\begin{array}{l}\text { A.9.4.1.1, } \\
\text { CAS 10-09-03, } \\
\text { Mud Pit }\end{array}$ & $\begin{array}{l}\text { "A surface sample }(0 \text { to } 15 \mathrm{~cm}) \\
\text { will be collected at this location } \\
\text { as well as a depth sample from } \\
\text { just below the drilling mud and } \\
\text { crater interface." }\end{array}$ & $\begin{array}{l}\text { The surface sample }(0 \text { to } 15 \mathrm{~cm}) \text { was } \\
\text { collected. No sample at the interface was } \\
\text { collected because the interface could not be } \\
\text { distinguished at } 30 \mathrm{~cm} \text { depth. }\end{array}$ & $\begin{array}{l}\text { None. Based on previous investigations of mud } \\
\text { pits on the NNSS, the physical properties of mud } \\
\text { pit material limit significant vertical migration } \\
\text { (NNSA/NSO, 2004). There is no reason to } \\
\text { suspect that the mud material within the Ess } \\
\text { crater is different than mud pit mixtures historically } \\
\text { used throughout the NNSS. }\end{array}$ \\
\hline
\end{tabular}




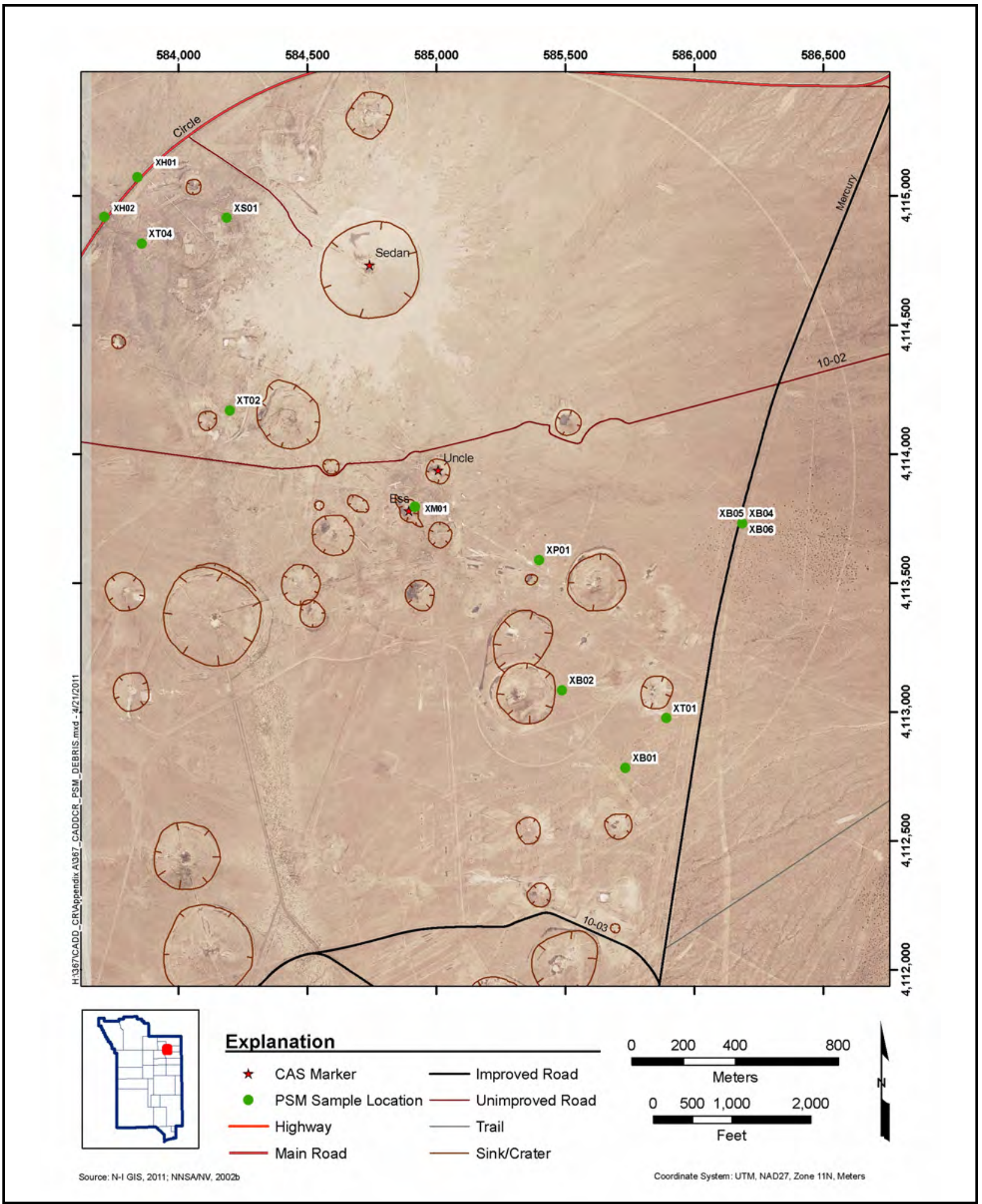

Figure A.4-3

Other Release Sample Locations 


\section{A.4.3.2 Results}

Neither VOCs nor SVOCs were detected above the MDCs in the Ess mud pit samples; thus, no chemical contaminants were identified at the site. The analytical results for radionuclides were evaluated by calculating a dose rate using the Industrial Area exposure scenario as described in Section A.2.2.5. Because a TLD was not installed at the mud pit, the external dose was calculated using RESRAD Version 6.5 and factored into the RRMG calculation. The maximum TED at sample location XM01 was 1.78 mrem/IA-yr, which is lower than the PAL of $25 \mathrm{mrem} / \mathrm{yr}$ under the Industrial Area exposure scenario.

The Akbar mud pit characteristics were evaluated against the mud pit closure criteria for LLNL pretest mud pits generally discussed in the Mud Pit Risk-Based Closure Strategy Report (NNSA/NSO, 2004) and detailed in the Closure Report for Corrective Action Units 530, 531, 532, 533, 534, 535: NTS Mud Pits, Nevada Test Site, Nevada (NNSA/NSO, 2006a). The Akbar mud pit is similar to LLNL pretest mud pits in Area 10 that were closed as part of CAU 532. It is recommended in NNSA/NSO (2006a) that if the following closure criteria are met, the mud pit should be transferred directly from Appendix II to Appendix IV of the FFACO:

- The CAS is either a single mud pit or a system of mud pits.

- The CAS is not located in a radiological or radioactive material posted area.

- The CAS does not serve as a habitat for threatened and endangered species.

- There are no biasing factors evident based on a visual inspection.

The Akbar mud pit is a single earthen, large-return mud pit that was not covered with native soils after use. This mud pit is not located in a radiological or radioactive material posted area, nor is it located within the range of the currently listed threatened and endangered species on the NNSS. The visual inspection of the Akbar mud pit did not identify any biasing factors. Thus, the Akbar mud pit meets all required criteria for closure without sampling.

\section{A.4.3.3 Deviations}

As indicated in Table A.4-1, the CAIP for CAU 367 stated that in addition to a sample of mud material collected at the surface, one subsurface sample would be collected just below the interface of the mud material and native soil. This interface was not encountered during sampling at the mud pit, and as a result, a second sample of mud pit material was not collected. 
Because of its location within the Ess crater, the mud material is presumed to have been deposited during post-test drilling conducted by LANL, the laboratory that conducted the Ess test. Because LANL used a consistent procedure when conducting post-test drilling on the NNSS, there is no reason to suspect that the mud material within the Ess crater is different from mud pit mixtures historically used by LANL throughout the NNSS. Previous investigations of mud pits have shown that the physical properties of the bentonite mud mixtures retard the vertical migration of potential contaminants (NNSA/NSO, 2004). These studies did not reveal any evidence of migration of contaminants to the underlying soil at mud pits on the NNSS. In addition, due to mud mixing during the drilling process, the drilling mud is homogeneous (i.e., there is no significant difference chemically between the top, middle, and bottom of the mud pits). Thus, the single sample at the Ess mud pit surface is sufficient to characterize the entire mud pit, and the absence of a sample at the drilling mud/native soil interface does not adversely impact the investigation. This deviation did not adversely impact the CAI or the resolution of DQOs for CAU 367.

\section{A.4.3.4 Summary}

No chemical COCs were detected in the samples of Ess mud pit material, and the calculated dose at this location is below the PAL of 25 mrem/IA-yr. Thus, no further action is required at the Ess mud pit.

The evaluation of the Akbar mud pit against the NNSS mud pit closure criteria indicates that this mud pit may be closed without further action.

\section{A.4.4 Potential Source Material}

The visual surveys conducted at CAU 367 over the course of the CAI (Sections A.2.2.1 and A.3.1.1) resulted in the identification of several debris items. These items included large and small metal fragments, batteries, empty containers, construction rubble piles, lead and steel shot, and tar pieces (Table A.4-2). 
Table A.4-2

Debris Items at CAU 367

\begin{tabular}{|c|c|c|c|c|}
\hline $\begin{array}{c}\text { Sample } \\
\text { Locatio } \\
n\end{array}$ & $\begin{array}{l}\text { Sample } \\
\text { Number }\end{array}$ & Debris Description & PSM Status & Action Taken \\
\hline XB01 & $367 X B 01$ & Deteriorated dry cell battery & Non-PSM & Debris removed \\
\hline XB02 & $\begin{array}{l}367 X B 02 \\
367 X B 03\end{array}$ & Deteriorated dry cell battery & Non-PSM & Debris removed \\
\hline $\begin{array}{l}\text { XB04 } \\
\text { XB05 } \\
\text { XB06 }\end{array}$ & $\begin{array}{l}367 \text { XB04 } \\
367 \text { XB05 } \\
367 \text { X06 }\end{array}$ & Deteriorated lead-acid battery & PSM & $\begin{array}{l}\text { Debris removed; } \\
\text { soil removal action implemented }\end{array}$ \\
\hline XP01 & 367XP01 & Paint can & Non-PSM & Debris removed \\
\hline XS01 & $367 X S 01$ & Lead and steel shot & PSM & To be closed under CAU 548 \\
\hline XT01 & $367 X T 01$ & Tar, plastic-like black material & PSM & To be closed under CAU 548 \\
\hline XT02 & $\begin{array}{l}367 X T 02 \\
367 X T 03\end{array}$ & Tar, plastic-like black material & PSM & To be closed under CAU 548 \\
\hline XT04 & $367 \times T 04$ & Tar, plastic-like black material & Non-PSM & Left in place \\
\hline \multirow{7}{*}{$\begin{array}{c}\text { No } \\
\text { samples } \\
\text { collected }\end{array}$} & \multirow{7}{*}{$\mathrm{N} / \mathrm{A}$} & Empty drum & Non-PSM & Debris removed \\
\hline & & $\begin{array}{c}\text { Empty drum, } \\
\text { empty 5-gallon metal cans }\end{array}$ & Non-PSM & Debris removed \\
\hline & & Empty drum & Non-PSM & Debris removed \\
\hline & & Empty drum & Non-PSM & Debris removed \\
\hline & & Crushed metal container & Non-PSM & Debris removed \\
\hline & & Metal items & Non-PSM & Left in place \\
\hline & & Instrumentation from tests & Unknown & Historically significant; left in place \\
\hline
\end{tabular}

N/A = Not applicable

\section{A.4.4.1 Corrective Action Investigation Activities}

The debris items were evaluated for their potential to release contaminants to the environment or result in a radiological dose to a receptor using process knowledge, radiological surveys, and/or sampling. Radiological surveys, including the collection of removable contamination swipes, were performed on 10 of the metal debris items.

Sampling was conducted at the locations of debris items where, based on the nature of the debris, it was determined that there was a potential for a release. The debris items at these locations included 
two dry cell batteries, one lead-acid battery, lead and steel shot, tar pieces, and an empty 1-gallon paint container. A total of 13 soil samples were collected from the debris item locations listed in Table A.4-3. The laboratory analyses conducted for the samples were limited to those constituents expected to be in or on the debris item based on its composition or common use. At the three battery locations (XB01, XB02, and XB04), the debris item was removed along with a small amount of soil. One soil sample was collected directly beneath the debris item at each location. The three battery location samples were analyzed for total Resource Conservation and Recovery Act (RCRA) metals. At the paint can location (XP01), the paint can was removed and one soil sample was collected beneath the can. This sample was analyzed for total RCRA metals and total SVOCs. The debris at the lead/steel shot and tar locations was not removed, but samples were collected at each location to determine whether the material was PSM. At the lead/steel shot location (XS01), one soil sample (367XS01) was collected at a depth of 4 to 8 in. bgs. The purpose of this sample was to determine whether the shot constituents had leached into the soil, so the sample was collected at the depth at which no shot was visible. This sample was analyzed for total RCRA metals and gamma spectroscopy. In addition, one sample of soil containing lead/steel shot was collected from this location and analyzed for total lead (367WM02). At each of the three tar locations (XT01, XT02, and XT04), one soil sample was collected from beneath the solidified tar substance. The tar soil samples were analyzed for total RCRA metals and total SVOCs. Waste characterization samples of these items (tar, batteries, and shot) also were collected and are discussed in Section A.5.0.

\section{A.4.4.2 Results}

No removable radiological contamination was found on any of the surveyed metal items. The surveys of the individual metal items, in conjunction with the results of the large area transect radiological surveys, indicate that the presence of the metal debris does not impact the conclusions of the CAI or the corrective actions implemented at the site.

The analytical results of the potential release soil samples are found in Table A.4-3. Radiological and chemical constituents detected in each of the soil samples were below the FALs, with the following exceptions: lead was detected at the deteriorated lead-acid battery and lead/steel shot locations, and benzo(a)pyrene was detected at two of the three tar locations. 
Table A.4-3

Sample Results above MDCs at PSM Sample Locations

\begin{tabular}{|c|c|c|c|c|c|c|c|c|c|c|c|c|c|c|c|c|c|c|c|c|c|c|c|c|c|c|c|c|c|c|c|c|}
\hline \multirow[b]{2}{*}{ 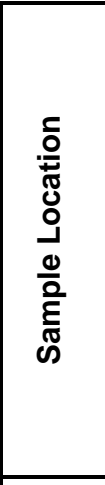 } & \multirow[b]{2}{*}{ 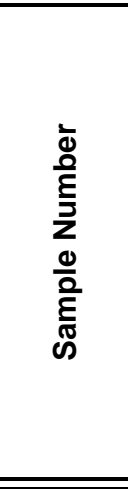 } & \multirow[b]{2}{*}{ 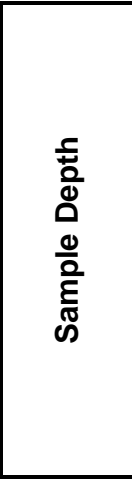 } & \multicolumn{19}{|c|}{$\begin{array}{c}\text { Total SVOCs } \\
(\mathrm{mg} / \mathrm{kg})\end{array}$} & \multicolumn{8}{|c|}{$\begin{array}{c}\text { Total Metals } \\
(\mathrm{mg} / \mathrm{kg})\end{array}$} & \multicolumn{3}{|c|}{$\begin{array}{c}\text { Radionuclides } \\
\text { (pCi/g) }\end{array}$} \\
\hline & & & 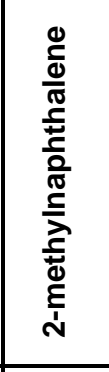 & 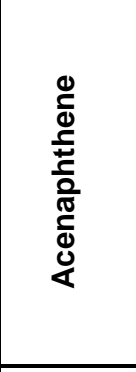 & 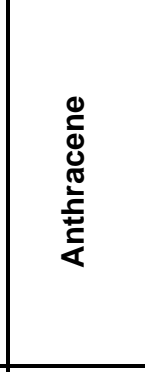 & 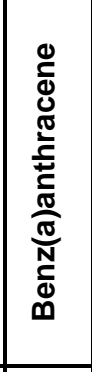 & 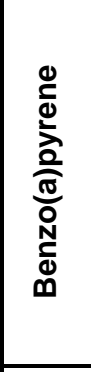 & 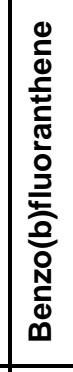 & 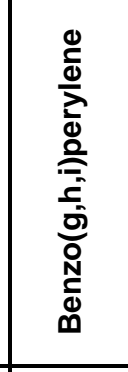 & 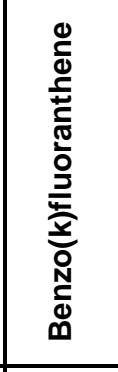 & 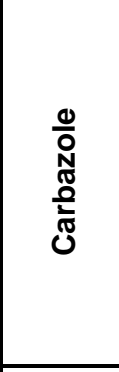 & 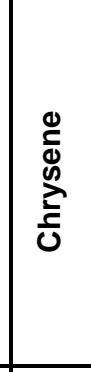 & 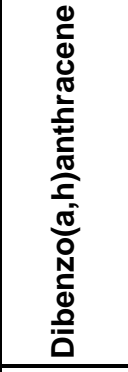 & 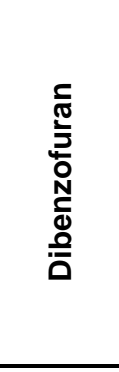 & 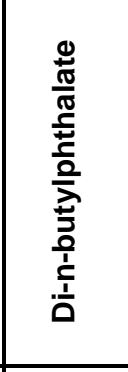 & 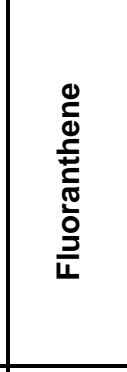 & 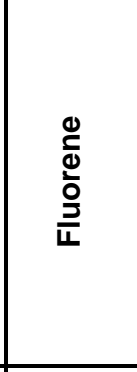 & 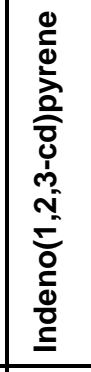 & 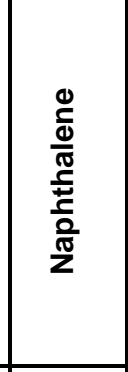 & 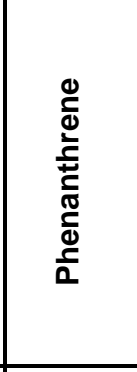 & 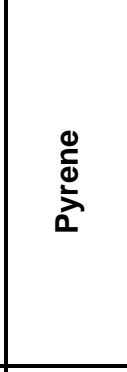 & 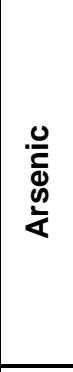 & 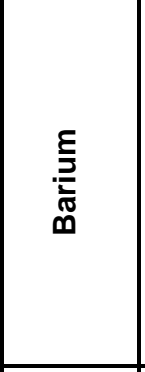 & 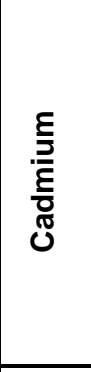 & 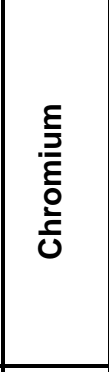 & ฐ్త్ర & 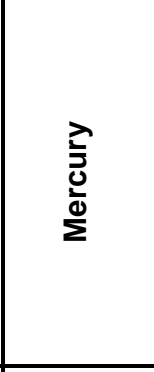 & 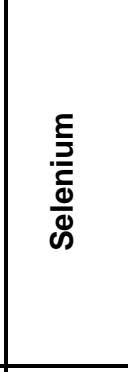 & $\stackrel{\overline{\bar{\nu}}}{\overline{\bar{\omega}}}$ & 岕 & 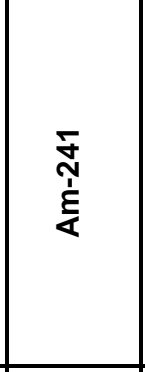 & 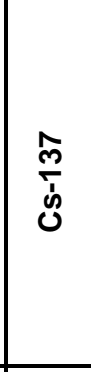 \\
\hline \multicolumn{3}{|c|}{ FALS } & 4,100 & 33,000 & 170,000 & 2.1 & 0.21 & 2.1 & 17,000 & 21 & 95.8 & 210 & $\overline{0.21}$ & 1,000 & $\overline{62,000}$ & 22,000 & 22,000 & 2.1 & $\bar{~} 18$ & 170,000 & 17,000 & 23 & 190,000 & 800 & $39.2^{\mathrm{a}}$ & 800 & 34 & \begin{tabular}{|l|l|} 
& 5,100
\end{tabular} & 5,100 & 5 & 12.7 & \begin{tabular}{|l|}
12.2 \\
\end{tabular} \\
\hline XB01 & "367XB01 & 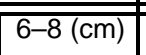 & & & & & & & & & & & & & & & & & & & & " & 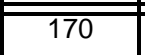 & "2.8 & 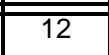 & 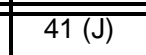 & $\overline{0.0073(\mathrm{~J}-)}$ & $=$ & -- & & & \\
\hline \multirow{2}{*}{ Хво2 } & \begin{tabular}{|l|}
$367 \times$ 02 \\
\end{tabular} & \begin{tabular}{|l|}
$2-5(\mathrm{~cm})$ \\
\end{tabular} & & & & & & & & & & & & & & & & & & & & 5.3 & 170 & \begin{tabular}{|l|}
4.6 \\
\end{tabular} & 7.8 & $200(\mathrm{~J})$ & 7.8 & 3.1 & 1.2 & & & \\
\hline & \begin{tabular}{|l|}
$367 \times B 03$ \\
\end{tabular} & $2-5(\mathrm{~cm})$ & & & & & & & & & & & & & & & & & & & & \begin{tabular}{|l|l}
4.7 \\
\end{tabular} & 150 & 4 & 6.9 & $160(\mathrm{~J})$ & 7.5 & 1.8 & 0.71 & & & \\
\hline \begin{tabular}{|l|} 
XB04 \\
\end{tabular} & \begin{tabular}{|l|}
$367 \times B 04$ \\
\end{tabular} & $2-5(\mathrm{~cm})$ & & & & & & & & & & & & & & & & & & & & \begin{tabular}{|l|l|}
6.9 \\
\end{tabular} & 150 & -- & 6.8 & $5,200(\mathrm{~J})$ & 0.043 & -- & -- & & & \\
\hline \begin{tabular}{|l|}
$\mathrm{XB05}$ \\
\end{tabular} & \begin{tabular}{|l|l|}
$367 X 05$ \\
\end{tabular} & \begin{tabular}{|l|}
$6-9$ (in.) \\
\end{tabular} & & & & & & & & & & & & & & & & & & & & & & & & 20 & & & & & & \\
\hline \begin{tabular}{|l|}
$\mathrm{XB} 06$ \\
\end{tabular} & \begin{tabular}{|l|}
$367 \times B 06$ \\
\end{tabular} & \begin{tabular}{|l|}
$6-9$ (in.) \\
\end{tabular} & & & & & & & & & & & & & & & & & & & & & & & & 210 & & & & & & \\
\hline \begin{tabular}{|l|} 
XP01 \\
\end{tabular} & \begin{tabular}{|l|}
$367 X P 01$ \\
\end{tabular} & \begin{tabular}{|l|}
$1-2$ (in.) \\
\end{tabular} & -- & -- & -- & -- & -- & -- & -- & -- & -- & -- & -- & -- & -- & - & -- & -- & -- & -- & -- & \begin{tabular}{|l|l|}
3.4 \\
\end{tabular} & 170 & -- & 8.6 & $36(\mathrm{~J})$ & \begin{tabular}{|l|}
$0.029(\mathrm{~J}-)$ \\
\end{tabular} & -- & -- & & & \\
\hline \multirow{2}{*}{ Xs01 } & \begin{tabular}{|l|}
$367 X S 01$ \\
\end{tabular} & \begin{tabular}{|l|}
$4-8$ (in.) \\
\end{tabular} & & & & & & & & & & & & & & & & & & & & $\begin{array}{ll}6.3 \\
\end{array}$ & 160 & -- & 8.6 & $30(\mathrm{~J})$ & $0.023(\mathrm{~J}-)$ & 0.34 & -- & 1.31 & $5.77(\mathrm{~J}+)$ & 9.5 \\
\hline & $367 \mathrm{WM} 02$ & \begin{tabular}{|l|}
$0-4$ (in.) \\
\end{tabular} & & & & & & & & & & & & & & & & & & & & & & & & 34,000 & & & & -- & 0.053 & 1.1 \\
\hline \begin{tabular}{|l|} 
XT01 \\
\end{tabular} & \begin{tabular}{|l|l}
$367 \times T 01$ \\
\end{tabular} & \begin{tabular}{|l|}
$1-2$ (in.) \\
\end{tabular} & 0.52 & \begin{tabular}{|l|l}
$0.098(\mathrm{~J})$ \\
\end{tabular} & \begin{tabular}{|l|}
$0.19(\mathrm{~J})$ \\
\end{tabular} & \begin{tabular}{|l|}
0.92 \\
\end{tabular} & 0.8 & 1.3 & 0.42 & 0.5 & \begin{tabular}{|l|l}
$0.19(\mathrm{~J})$ \\
\end{tabular} & \begin{tabular}{|l|}
1.2 \\
\end{tabular} & $0.16(\mathrm{~J})$ & $0.18(\mathrm{~J})$ & 1.9 & 2.3 & $0.15(\mathrm{~J})$ & \begin{tabular}{|l|}
0.4 \\
\end{tabular} & $0.18(\mathrm{~J})$ & 1.5 & 1.7 & \begin{tabular}{|l|l}
5.2 \\
\end{tabular} & 160 & -- & 7.4 & $12(\mathrm{~J})$ & $0.017(\mathrm{~J}-)$ & -- & -- & & & \\
\hline \multirow{2}{*}{ хT02 } & \begin{tabular}{|l|}
$367 \times T 02$ \\
\end{tabular} & \begin{tabular}{|l|}
$1-2$ (in.) \\
\end{tabular} & -- & -- & $0.088(\mathrm{~J})$ & \begin{tabular}{|l|}
0.42 \\
\end{tabular} & 0.5 & 1.3 & 0.9 & $\begin{array}{l}0.47 \\
\end{array}$ & $0.12(\mathrm{~J})$ & 0.54 & $0.18(\mathrm{~J})$ & -- & 1.4 & 1.4 & -- & 0.61 & -- & 0.75 & 1 & \begin{tabular}{|l|l|}
3.4 \\
\end{tabular} & 96 & -- & 5.3 & $11(\mathrm{~J})$ & $0.011(\mathrm{~J}-)$ & -- & -- & & & \\
\hline & \begin{tabular}{|l|}
$367 \times T 03$ \\
\end{tabular} & \begin{tabular}{|l|}
$1-2$ (in.) \\
\end{tabular} & -- & -- & -- & \begin{tabular}{|l|}
0.36 \\
\end{tabular} & 0.4 & 1.2 & 0.72 & $0.33(\mathrm{~J})$ & -- & 0.43 & $0.14(\mathrm{~J})$ & -- & 1 & 1 & -- & $\begin{array}{l}0.49 \\
\end{array}$ & -- & 0.42 & 0.73 & $\begin{array}{ll}3.6 \\
\end{array}$ & 140 & -- & 5.1 & $16(\mathrm{~J})$ & $0.009(\mathrm{~J}-)$ & -- & -- & & & \\
\hline \begin{tabular}{|l|} 
XTO4 \\
\end{tabular} & \begin{tabular}{|l|}
$367 \times T 04$ \\
\end{tabular} & \begin{tabular}{|l|}
$2-4$ (in.) \\
\end{tabular} & -- & -- & -- & -- & -- & $1--$ & -- & -- & -- & -- & -- & - & -- & -- & - & -- & -- & - & -- & \begin{tabular}{|l}
8.3 \\
\end{tabular} & 220 & - & 12 & $19(\mathrm{~J})$ & $0.035(\mathrm{~J}-)$ & 0.31 & - & & & \\
\hline
\end{tabular}

${ }^{2}$ Total chromium FAL calculated using the Cr-VI PAL and the 6:1 Cr-III:Cr-VI ratio: $5.6 \mathrm{mg} / \mathrm{kg}$ (Cr-VI PAL) $\times 7=39.2 \mathrm{mg} / \mathrm{kg}$

Blank cells indicate sample was not analyzed for that constituent.

$=$ Not detected above MDC

$\mathrm{J}=$ Estimated value

$\mathrm{J}-=$ Estimate value (low)
$\mathrm{J}+=$ Estimated value (high) 
Lead was detected in soil sample 367XB04 from the lead-acid battery location at a concentration of $5,200 \mathrm{mg} / \mathrm{kg}$, which is greater than the lead FAL of $800 \mathrm{mg} / \mathrm{kg}$. A corrective action was implemented at the lead-acid battery location based on the expectation that lead migration would be limited due to the size of the release source. The soil underneath and surrounding the battery location was removed, and two verification samples (367XB05 and 367XB06) were collected and analyzed for total lead. Lead was not detected in either of the verification samples in excess of the FAL (Table A.4-3).

Lead was detected in the sample of soil and shot (367WM02) at a concentration of 34,000 mg/kg. This sample was also analyzed for Toxicity Characteristic Leaching Procedure (TCLP) metals and did not exceed the limit for lead or any other metal (see Section A.5.0). In the soil sample collected beneath the lead/steel shot (367XS01), lead was detected at $30 \mathrm{mg} / \mathrm{kg}$, well below the FAL of $800 \mathrm{mg} / \mathrm{kg}$. The high concentration of lead in sample 367WM02 indicates that this debris is PSM; however, the potential length of time the shot has been exposed and the TCLP data suggest that the lead does not readily leach to the surrounding soil. The area that contains the lead/steel shot is approximately $75 \mathrm{~m}^{2}$, and the shot was found as deep as $4 \mathrm{in}$. bgs. A portion of the shot is located within a fenced area encompassing two underground tests (Portola and Portola-Larkin), which are not part of CAU 367. These tests were detonated in 1975 in a single emplacement hole U-10bb (DOE/NV, 2000). Because the stability of the subsurface within the fenced area is currently unknown, the lead/steel shot was not removed as part of CAU 367. Instead, the investigation of the lead/steel shot will be deferred until information on the stability of the subsurface becomes available. The sample data from this location are presented in this report for completeness. For accountability purposes, the location will be added to CAU 548, Areas 9, 10, 18, 19, and 20 Housekeeping Sites.

Benzo(a)pyrene was detected above the FAL of $0.21 \mathrm{mg} / \mathrm{kg}$ at two of the tar locations. At location XT01, benzo(a)pyrene was detected at a concentration of $0.8 \mathrm{mg} / \mathrm{kg}$ and at location XT02 at 0.5 and $0.4 \mathrm{mg} / \mathrm{kg}$ (FD sample). The approximate area of each of the tar locations is $11 \mathrm{~m}^{2}$. Although it appears that the release of tar was limited to the surface, the actual depth of the tar is unknown. Because this release is not associated with CAU 367 releases and there is the potential for a large soil removal action, the two tar locations were not closed as part of CAU 367. Instead, these locations will be closed as part of CAU 548, Areas 9, 10, 18, 19, and 20 Housekeeping Sites. The data from the tar locations are presented in this report for completeness. 
The category of each debris item (i.e., PSM or non-PSM) and the action taken as a result of the investigation are presented in Table A.4-2. Non-PSM debris items were removed and disposed of as a BMP. These items included empty 55-gallon metal drums, empty 5-gallon metal containers, and a crushed metal container. Section A.5.2 details the characterization and disposal of the identified PSM and other non-PSM items removed from the site as part of CAU 367 closure activities.

\section{A.4.4.3 Deviations}

No deviations from the CAU 367 CAIP were noted.

\section{A.4.4.4 Summary}

Lead was identified as a COC at one CAU 367 debris location (XB04). The lead contamination was associated with a lead-acid battery. The battery was removed and a limited soil removal action was implemented at this location. Verification soil samples indicate that the lead contamination was removed. Thus, no further action is necessary at this location.

Sampling at the lead/steel shot location (XS01) indicated a high concentration of lead, although the lead does not appear to have leached into the surrounding soil. The lead/steel shot location will be investigated as part of CAU 548, Areas 9, 10, 18, 19, and 20 Housekeeping Sites. Benzo(a)pyrene was detected above the FAL at two tar locations (XT01 and XT02), which will also be investigated as part of CAU 548, Areas 9, 10, 18, 19, and 20 Housekeeping Sites.

Because no COCs were detected above the FALs at the other debris sites, no further action is required at these locations.

\section{A.4.5 Nature and Extent of Contamination-Other Releases}

No COCs were identified at the Circle Road sample locations or at the Ess mud pit (CAS 10-09-03). As a result, no corrective action is required at these other release sites. The Akbar mud pit (CAS 10-09-03) met the required criteria for closure without sampling (Section A.4.3.2), so no further action is required at this location. 
Lead was found in the soil at a concentration above the FAL at the location of a deteriorated lead-acid battery. A soil removal corrective action was implemented at this location, and verification soil samples were collected and analyzed for lead. Verification samples confirmed that the lead contamination was removed. Based on the corrective action implemented at the lead-acid battery location, no further action is required.

The three deteriorated batteries and the empty paint can were removed from CAU 367 as part of site closure activities. Although corrective action was not required for non-PSM items identified in the site survey, select items were removed and disposed of as a BMP.

\section{A.4.6 Revised Conceptual Site Model-Other Releases}

The CAIP requirements were met at the other release locations. The information gathered during the CAI supports the CSM as presented in the CAIP for CAU 367. Therefore, no revisions to the CSM were necessary. 


\section{A.5.0 Waste Management}

The following sections describe the waste management activities completed during the CAI and closure activities at CAU 367. Waste types generated include industrial waste, mixed low-level waste, and nonregulated waste (i.e., recyclable material). All wastes and recyclable materials were managed in accordance with federal and state regulations, permit limitations, and disposal facility waste acceptance criteria. Waste management activities were conducted as specified in the CAIP. A summary of the waste streams generated, the waste type (i.e., characterization), and waste disposition is provided in Table A.5-1.

\section{A.5.1 Waste Generation}

The following wastes were generated during the CAU 367 field investigation:

- Disposable personal protective equipment (PPE) and sampling equipment

- Environmental media

- $\quad$ Surface debris (e.g., batteries, metal, empty containers)

All waste streams were field screened as generated to comply with the radiological release limits of Table 4-2 of the Nevada Test Site Radiological Control Manual (NNSA/NSO, 2010b).

\section{A.5.2 Waste Characterization}

The analytical results detected above MDCs for soil and PSM samples are presented in Table A.5-2. The analytical suite was tailored to characterize the waste for disposal and to support recommended closure actions. Results were reviewed against federal regulations, state regulations, and DOE directives, policies, and guidance, as well as waste disposal criteria for NNSS disposal facilities.

It should be noted that the analytical results for PSM samples from the three tar locations (367WM04, 367WM05, and 367WM06) and the lead/steel shot location (367WM02) are reported in Table A.5-2 for completeness. No waste was generated at these locations as a result of the CAU 367 CAI (as mentioned in the discussion of the scope of CAU 367 in Section 1.2). 
Table A.5-1

Page A-73 of A-86

Waste Summary

\begin{tabular}{|c|c|c|c|c|c|c|c|c|c|}
\hline \multirow{2}{*}{ Waste Type } & \multirow{2}{*}{ Description } & \multicolumn{4}{|c|}{ Waste Characterization } & \multicolumn{4}{|c|}{ Waste Disposal } \\
\hline & & Hazardous & Radioactive & Hydrocarbon & PCBs & $\begin{array}{l}\text { Disposal } \\
\text { Facility }\end{array}$ & $\begin{array}{l}\text { Waste } \\
\text { Volume }\end{array}$ & $\begin{array}{l}\text { Disposal } \\
\text { Date }\end{array}$ & $\begin{array}{l}\text { Disposal } \\
\text { Document }\end{array}$ \\
\hline \multirow{2}{*}{$\begin{array}{l}\text { Industrial } \\
\text { Waste }\end{array}$} & $\begin{array}{l}\text { Sampling } \\
\text { Equipment } \\
\text { and PPE }\end{array}$ & No & No & No & No & $\begin{array}{l}\text { NNSS, U10c } \\
\text { Landfill }\end{array}$ & $10 \mathrm{yd}^{3}$ & $12 / 08 / 2010$ & $\begin{array}{c}\text { Load } \\
\text { Verification } \\
\text { Form }\end{array}$ \\
\hline & Surface Debris & No & No & No & No & $\begin{array}{l}\text { NNSS, U10c } \\
\text { Landfill }\end{array}$ & $5 y d^{3}$ & $04 / 21 / 2011$ & $\begin{array}{l}\text { Load } \\
\text { Verification } \\
\text { Form }\end{array}$ \\
\hline $\begin{array}{l}\text { Mixed } \\
\text { Low-Level } \\
\text { Waste }\end{array}$ & Soil & Yes & Yes & No & No & $\begin{array}{l}\text { Offsite Disposal } \\
\text { Facility (TBD) }\end{array}$ & $0.1 \mathrm{yd}^{3}$ & 06/09/2011 & $\begin{array}{c}\text { Onsite } \\
\text { Manifest }\end{array}$ \\
\hline $\begin{array}{c}\text { Recyclable } \\
\text { Materials }\end{array}$ & Lead-Acid Battery & No & No & No & No & Toxco, Inc. & 1 Battery & N/A & None \\
\hline $\begin{array}{l}\text { Low-Level } \\
\text { Waste }\end{array}$ & $\begin{array}{l}\text { Dry-cell batteries } \\
\text { and soil }\end{array}$ & No & Yes & No & No & $\begin{array}{c}\text { NNSS, } \\
\text { Area 5 } \\
\text { Radioactive } \\
\text { Waste } \\
\text { Management } \\
\text { Complex }\end{array}$ & $0.3 \mathrm{yd}^{3}$ & 06/09/2011 & $\begin{array}{c}\text { Onsite } \\
\text { Manifest } \\
\text { Certificate of } \\
\text { Disposal }\end{array}$ \\
\hline
\end{tabular}

PCB = Polychlorinated biphenyl

$\mathrm{TBD}=$ To be determined

$\mathrm{yd}^{3}=$ Cubic yard 
Table A.5-2

Waste Characterization Sample Results

\begin{tabular}{|c|c|c|c|c|c|c|c|}
\hline $\begin{array}{c}\text { Sample } \\
\text { Location }\end{array}$ & $\begin{array}{l}\text { Sample } \\
\text { Number }\end{array}$ & $\begin{array}{c}\text { Depth } \\
\text { (in. bgs) }\end{array}$ & Matrix & Parameter & Result & Criteria $^{a}$ & Units \\
\hline \multirow{4}{*}{ XS01 } & \multirow{4}{*}{ 367WM02 } & \multirow{4}{*}{$0-4$} & \multirow{4}{*}{$\begin{array}{c}\text { Solid } \\
\text { (shot and soil) }\end{array}$} & Chromium & 0.023 & $\overline{5}$ & \multirow{8}{*}{$\mathrm{mg} / \mathrm{L}$} \\
\hline & & & & Lead & 0.74 & 5 & \\
\hline & & & & Am-241 & 0.53 & $10^{\mathrm{b}}$ & \\
\hline & & & & Cs-137 & 1.1 & $100^{b}$ & \\
\hline \multirow{2}{*}{ XT01 } & \multirow{2}{*}{ 367WM04 } & \multirow{2}{*}{$0-1$} & \multirow{2}{*}{$\begin{array}{l}\text { Solid } \\
\text { (tar) }\end{array}$} & Lead & 0.025 & 5 & \\
\hline & & & & Pentachlorophenol & $0.058(\mathrm{~J})$ & 100 & \\
\hline XT02 & 367WM05 & $0-1$ & $\begin{array}{r}\text { Solid } \\
\text { (tar) }\end{array}$ & Lead & 0.014 & 5 & \\
\hline XT04 & 367WM06 & $0-2$ & $\begin{array}{r}\text { Solid } \\
\text { (tar) }\end{array}$ & Mercury & 0.00019 & 0.2 & \\
\hline \multirow{7}{*}{ NISAA018 } & \multirow{7}{*}{ 367WM07 } & \multirow{7}{*}{$\mathrm{N} / \mathrm{A}$} & \multirow{11}{*}{ Soil } & Am-241 & $2.15(\mathrm{~J}+)$ & $10^{b}$ & \multirow{5}{*}{$\mathrm{pCi} / \mathrm{g}$} \\
\hline & & & & Cs-137 & 13.2 & $100^{b}$ & \\
\hline & & & & Pu-238 & 1.17 & $10^{b}$ & \\
\hline & & & & Pu-239/240 & 15.8 & $10^{\mathrm{b}}$ & \\
\hline & & & & Sr-90 & $5.1(\mathrm{~J}+)$ & $100^{\mathrm{b}}$ & \\
\hline & & & & Lead & 0.22 & 5 & \multirow{2}{*}{$\mathrm{mg} / \mathrm{L}$} \\
\hline & & & & Mercury & 0.00011 & 0.2 & \\
\hline \multirow{4}{*}{ NISAA019 } & \multirow{4}{*}{ 367WM01 } & \multirow{4}{*}{$\mathrm{N} / \mathrm{A}$} & & Am-241 & $6.66(\mathrm{~J}+)$ & $0.5^{c}$ & \multirow{2}{*}{$\mathrm{pCi} / \mathrm{g}$} \\
\hline & & & & Cs-137 & 17.1 & $3^{c}$ & \\
\hline & & & & Arsenic & 0.36 & 5 & \multirow{2}{*}{$\mathrm{mg} / \mathrm{L}$} \\
\hline & & & & Lead & 760 & 5 & \\
\hline
\end{tabular}

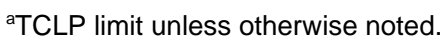

${ }^{b}$ Radionuclide limits in NNSS, U10c landfill permit.

${ }^{\mathrm{c}}$ Radionuclide limits in the Nevada Test Site Performance Objective for Certification of Nonradioactive Hazardous Waste (BN, 1995).

Applicable to hazardous waste exiting the NNSS.

$\mathrm{J}=$ Estimated value

$\mathrm{J}+=$ Result is an estimated quantity, but may be biased high.

Note: Bolded values exceed applicable criteria.

$\mathrm{mg} / \mathrm{L}=$ Milligrams per liter 


\section{A.5.2.1 Industrial Waste}

Page A-75 of A-86

Industrial wastes were characterized based on process knowledge, radiological surveys, and sampling results, where available.

\section{A.5.2.1.1 Sampling Equipment and PPE}

Disposable sampling equipment and PPE were collected, bagged, labeled, and placed in a roll-off container at Building 23-153 on a daily basis. This waste was characterized based on process knowledge; no samples were collected of this waste. The disposal documentation for this waste is presented in Attachment D-1.

\section{A.5.2.1.2 Surface Debris}

A total of $5 \mathrm{yd}^{3}$ of surface debris (empty metal drums and containers) was generated. The metal debris was radiologically surveyed for contamination and characterized as industrial waste. This waste met the disposal criteria for the U10c landfill and was disposed of on April 21, 2011. The disposal documentation for this waste is presented in Attachment D-1.

\section{A.5.2.2 Mixed Low-Level Waste}

One 10-gallon drum containing soil and plastic debris from the location of a lead-acid battery was generated. A sample of the waste (367WM01) was collected and analyzed for TCLP RCRA metals and gamma spectroscopy. The analytical results show lead at a concentration of $760 \mathrm{mg} / \mathrm{L}$, which exceeds the RCRA TCLP limit of $5 \mathrm{mg} / \mathrm{L}$. Thus, this waste is considered hazardous waste. Because hazardous waste generated at the NNSS must be shipped off site for disposal, the radionuclide results were compared to criteria specific to hazardous waste being shipped from the NNSS to an offsite disposal facility (BN, 1995). The sample contained Am-241 at $6.66 \mathrm{pCi} / \mathrm{g}$ and $\mathrm{Cs}-137$ at $17.1 \mathrm{pCi} / \mathrm{g}$, which are above their respective criteria of 0.5 and 3 pCi/g (Table A.5-2). Therefore, the waste was characterized as mixed low-level waste and will be transported off site for disposal. The waste was transferred to the Area 5 mixed waste storage unit to await offsite disposal. The onsite manifest for this waste is presented in Attachment D-1. 


\section{A.5.2.3 Recyclable Materials}

One lead-acid battery was characterized as recyclable material based on process knowledge. The lead plates in this battery are considered scrap metal and will be recycled (i.e., the material is not considered waste and will not be disposed of). Under the scrap metal exemption of 40 CFR 261.4(a)(13), the lead plates are not considered solid waste (or hazardous waste) when recycled (CFR, 2010). The battery will be shipped off site when enough recyclable material is accumulated to make offsite shipment economical. The battery is currently staged at the lead recyclable materials area at Building 23-153 in Mercury awaiting final disposition at Toxco, Inc., in Oak Ridge, Tennessee. Because this is recyclable material, no disposal documentation is provided in this report.

\section{A.5.2.4 Low-Level Waste}

One 55-gallon drum that was approximately one-third full of deteriorated dry cell battery parts and associated soil was generated, characterized, and disposed of. A sample of the soil and battery debris (367WM07) was collected for waste characterization and analyzed for TCLP RCRA metals isotopic Pu, isotopic Sr-90, and gamma spectroscopy. Based on analytical results, the material was characterized as low-level radioactive waste and disposed of at the Area 5 Radioactive Waste Management Complex. The disposal documentation for this waste is presented in Attachment D-1. 


\section{A.6.0 Quality Assurance}

This section contains a summary of QA/QC measures implemented during the sampling and analysis activities conducted in support of the CAU 367 CAI. The following sections discuss the data validation process, QC samples, and nonconformances. A detailed evaluation of the DQIs is presented in Appendix B.

Laboratory analyses were conducted for samples used in the decision-making process to provide a quantitative measurement of any contaminants of potential concern (COPCs) present. Rigorous QA/QC was implemented for all laboratory samples, including documentation, verification and validation of analytical results, and affirmation of DQI requirements related to laboratory analysis. Detailed information regarding the QA program is contained in the Industrial Sites QAPP (NNSA/NV, 2002a).

\section{A.6.1 Data Validation}

Data validation was performed in accordance with the Industrial Sites QAPP (NNSA/NV, 2002a) and approved protocols and procedures. All laboratory data from samples collected and analyzed for CAU 367 were evaluated for data quality in a tiered process. Data were reviewed to ensure that samples were appropriately processed and analyzed, and the results were evaluated using validation criteria. Documentation of the data qualifications resulting from these reviews is retained in project files as a hard copy and electronic media.

All data analyzed as part of this investigation were subjected to Tier I and Tier II evaluations. A Tier III evaluation was performed on 5 percent of the data analyzed.

\section{A.6.1.1 Tier I Evaluation}

Tier I evaluation for chemical and radiochemical analysis examines, but is not limited to, the following items:

- Sample count/type consistent with chain of custody

- Analysis count/type consistent with chain of custody

- Correct sample matrix 
- Significant problems and/or nonconformances stated in cover letter or case narrative

- Completeness of certificates of analysis

- Completeness of Contract Laboratory Program (CLP) or CLP-like packages

- Completeness of signatures, dates, and times on chain of custody

- Condition-upon-receipt variance form included

- Requested analyses performed on all samples

- Date received/analyzed given for each sample

- Correct concentration units indicated

- Electronic data transfer supplied

- Results reported for field and laboratory QC samples

- Whether or not the deliverable met the overall objectives of the project

\section{A.6.1.2 Tier II Evaluation}

Tier II evaluation for radiochemical analysis examines, but is not limited to, the following items:

- Correct detection limits achieved

- Blank contamination evaluated and, if significant, qualifiers are applied to sample results

- Certificate of Analysis consistent with data package documentation

- Quality control sample results (duplicates, laboratory control samples [LCSs], laboratory blanks) evaluated and used to determine laboratory result qualifiers

- Sample results, uncertainty, and MDCs evaluated

- Detector system calibrated with National Institute of Standards and Technology (NIST)-traceable sources

- Calibration sources preparation was documented, demonstrating proper preparation and appropriateness for sample matrix, emission energies, and concentrations.

- Detector system response to daily or weekly background and calibration checks for peak energy, peak centroid, peak full-width half-maximum, and peak efficiency, depending on the detection system

- Tracers NIST-traceable, appropriate for the analysis performed, and recoveries that met QC requirements

- Documentation of all QC sample preparation complete and properly performed

- Spectra lines, photon emissions, particle energies, peak areas, and background peak areas support the identified radionuclide and its concentration. 


\section{A.6.1.3 Tier III Evaluation}

The Tier III review is an independent examination of the Tier II evaluation. A Tier III review of 5 percent of the sample radiological data was performed by TLI Solutions, Inc., in Golden, Colorado. Tier II and Tier III results were compared, and where differences are noted, data were reviewed and changes were made accordingly. This review included the following additional evaluations:

- Review

- Case narrative, chain of custody, and sample receipt forms

- $\quad$ Lab qualifiers (applied appropriately)

- Method of analyses performed as dictated by the chain of custody

- Raw data, including chromatograms, instrument printouts, preparation logs, and analytical logs

- Manual integrations to determine whether the response is appropriate

- Data package for completeness

- Determine sample results qualifiers through the evaluation of (but not limited to) the following:

- Tracers and QC sample results (e.g., duplicates, LCSs, blanks, matrix spikes) evaluated and used to determine sample results qualifiers

- Sample preservation, sample preparation/extraction and run logs, sample storage, and holding time

- Instrument and detector tuning

- Initial and continuing calibrations

- Calibration verification (initial, continuing, second source)

- Retention times

- Second column and/or second detector confirmation

- Mass spectra interpretation 
- Interference check samples and serial dilutions

- Post-digestion spikes and method of standard additions

- Breakdown evaluations

- Perform calculation checks of the following:

- At least one analyte per QC sample and its recovery

- At least one analyte per initial calibration curve, continuing calibration verification, and second source recovery

- At least one analyte per sample that contains positive results (hits); radiochemical results only require calculation checks on activity concentrations (not error).

- Verify that target compound detects identified in the raw data are reported on the results form.

- Document any anomalies for the laboratory to clarify or rectify. The contractor should be notified of any anomalies.

\section{A.6.2 Field QC Samples}

Field QC samples consisted of three full laboratory QCs, two field blanks, and one trip blank. These samples were collected and submitted for analysis by the laboratory analytical methods shown in Table A.2-1.

During the CAI, seven FDs were sent to the laboratory to be analyzed for the investigation parameters listed in Table A.2-1. The FD samples were assigned individual sample numbers and sent to the laboratory "blind." For these samples, relative percent differences (RPDs) between the environmental sample results and their corresponding FD sample results were evaluated for precision.

\section{A.6.2.1 Laboratory QC Samples}

Analysis of QC preparation blanks, LCSs, and laboratory duplicate samples was performed on each sample delivery group (SDG) for radionuclides. Initial and continuing calibration and LCSs were performed for each SDG. The results of these analyses were used to qualify associated environmental 
sample results. Documentation of data qualifications resulting from the application of these guidelines is retained in project files as both hard copy and electronic media.

\section{A.6.3 Field Nonconformances}

There were no field nonconformances identified for the CAI.

\section{A.6.4 Laboratory Nonconformances}

Laboratory nonconformances are generally due to fluctuations in analytical instrumentation operations, sample preparations, missed holding times, spectral interferences, and high or low chemical yields. Nine nonconformances were issued by the contracted laboratory. Of the nine nonconformances, five were addressed and corrected by the laboratory by reanalyzing samples prior to issuance of data reports. Two of the remaining four nonconformances resulted in data qualification. The last two nonconformances did not impact the resulting data. All laboratory nonconformances were reviewed and accounted for during the data validation process.

\section{A.6.5 Thermoluminescent Dosimeter Data Validation}

The use of a TLD to determine an individual's external exposure is the standard in radiation safety and serves as the "legal dose of record" when other measurements are not available. Specifically, 10 CFR 835.402 (CFR, 2011) stipulates that personal dosimeters shall be provided to monitor individual exposures and that monitoring programs using dosimeters shall be accredited in accordance with the DOE Laboratory Accreditation Program, as was the case for the TLDs used at CAU 367.

The TLDs were exposed at the CAU 367 sample locations for an exposure duration that met or exceeded the 2,250 hours of the Industrial Area exposure scenario. 


\section{A.7.0 Summary}

Corrective Action Unit 367 consists of four CASs: 10-45-01, U-10h Crater (Sedan); 10-45-02, Ess Crater Site; 10-45-03, Uncle Crater Site; and 10-09-03, Mud Pit. The crater CASs, 10-45-01, 10-45-02, and 10-45-03, consist of the release of radionuclides to surrounding soil from the Sedan, Ess, and Uncle tests, respectively. Corrective Action Site 10-09-03 consists of two mud pits identified at CAU 367. One was identified in the CAU 367 CAIP and is located at the bottom of the Ess crater. This mud pit consists of drilling mud likely associated with post-test drilling. The second mud pit was identified during the CAU 367 CAI and is located adjacent to a crater southeast of the Ess crater.

\section{Primary Release}

The three crater CASs at CAU 367-CASs 10-45-01, 10-45-02, and 10-45-03 — were investigated as one primary release. Radionuclide contaminants detected in environmental samples during the CAI were evaluated against the FAL of $25 \mathrm{mrem} / \mathrm{RW}$-yr to determine the nature and extent of COCs for CAU 367. Assessment of the data generated from surface soil samples collected at these primary release sites indicates that although surface radiological contamination exceeds the PALs (based on the Industrial Area exposure scenario), it does not exceed the FALs (based on the Remote Work Area exposure scenario). However, subsurface contamination exceeding the FALs is assumed to be present at all three CASs. Therefore, corrective action is required.

The selected corrective action for the three crater CASs is closure in place with a UR. The FFACO UR boundary at each crater surrounds the default contamination boundary that encompasses the crater and associated ejecta mounds surrounding the crater (Figure A.3-6).

\section{Other Releases}

No COCs were identified at the Circle Road sample locations or at the Ess mud pit (CAS 10-09-03). As a result, no corrective action is required at these other release sites. The Akbar mud pit (CAS 10-09-03) met the required criteria for closure without sampling (Section A.4.3.2), so no further action is required at this location. 
Potential source material was identified at eight locations: three sites containing tar pieces, three battery sites, one lead/steel shot site, and one empty 1-gallon paint container site. Lead was identified as a COC at one of the battery locations. A soil removal corrective action was implemented at this location, and verification soil samples confirmed that the lead contamination was removed. Based on the corrective action implemented at this location, no further action is required. Two of the tar locations and the lead/steel shot location will be transferred to CAU 548, Areas 9, 10, 18, 19, and 20 Housekeeping Sites. Because no COCs were detected above the FALs at any of the other debris sites, no further action is required at these locations. 


\section{A.8.0 References}

AEC, see Atomic Energy Commission.

Atomic Energy Commission. 1962. Project Sedan-Part 1, Film No. 800030. As accessed at http://www.nv.doe/library/films/film.aspx?ID=17 on 20 September 2009.

BN, see Bechtel Nevada.

Bechtel Nevada. 1995. Nevada Test Site Performance Objective for Certification of Nonradioactive Hazardous Waste, Rev. 0, G-E11/96.01. Las Vegas, NV.

Bechtel Nevada. 1999. An Aerial Radiological Survey of the Nevada Test Site, DOE/NV/11718--324. Prepared for U.S. Department of Energy, Nevada Operations Office. Las Vegas, NV: Remote Sensing Laboratory.

CFR, see Code of Federal Regulations.

Code of Federal Regulations. 2010. Title 40 CFR, Part 261, "Identification and Listing of Hazardous Waste,” Section 4, “Exclusions.” Washington, DC: U.S. Government Printing Office.

Code of Federal Regulations. 2011. Title 10 CFR, Part 835, “Occupational Radiation Protection,” Section 402, “Individual Monitoring.” Washington, DC: U.S. Government Printing Office.

DOE, see U.S. Department of Energy.

DOE/NV, see U.S. Department of Energy, Nevada Operations Office.

EPA, see U.S. Environmental Protection Agency.

Gray, K.J., D.S. Shafer, K. Self, C. Martin, and R. McArthur. 2007. Radionuclide Inventory and Distribution Program Database, Rev. 2. April. Las Vegas, NV: Desert Research Institute, Water Resources Center.

Hendricks, T., National Security Technologies, LLC. 2011. Personal communication to M. Knop (N-I) regarding natural background at NNSS and email transmittal of data files, 17 February. Las Vegas, NV.

McArthur, R.D., and S.W. Mead. 1987. Nevada Test Site Radionuclide Inventory and Distribution Program: Report \#3, Areas 3, 7, 8, 9, and 10, DOE/NV/10384-15; Publication No. 45056. Las Vegas, NV: Desert Research Institute, Water Resources Center. 
Murphy, T., Bureau of Federal Facilities. 2004. Letter to R. Bangerter (NNSA/NSO) titled "Review of Industrial Sites Project Document Guidance for Calculating Industrial Sites Project Remediation Goals for Radionuclides in Soil Using the Residual Radiation (RESRAD) Computer Code,” 19 November. Las Vegas, NV.

N-I GIS, see Navarro-Intera Geographic Information Systems.

NNES, see Navarro Nevada Environmental Services, LLC.

NNSA/NSO, see U.S. Department of Energy, National Nuclear Security Administration Nevada Site Office.

NNSA/NV, see U.S. Department of Energy, National Nuclear Security Administration Nevada Operations Office.

Navarro Nevada Environmental Services, LLC. 2009. Statement of Work for Analytical Laboratories, Section C. Las Vegas, NV.

Navarro-Intera Geographic Information Systems. 2011. ESRI ArcGIS Software.

PNNL, see Pacific Northwest National Laboratory.

Pacific Northwest National Laboratory. 2007. Visual Sample Plan, Version 5.0 User's Guide, PNNL-16939. Richland, WA.

Pacific Northwest National Laboratory. 2009. Methods and Models of the Hanford Internal Dosimetry Program, PNNL-MA-860, PNNL-15614, Rev. 1. Richland, WA.

U.S. Department of Energy. 1990. Compliance Assessment of the Nevada Test Site, DOE/EH-0115. Washington, DC: U.S. Department of Energy, Environment, Safety, and Health.

U.S. Department of Energy. 1997. The Procedures Manual of the Environmental Measurements Laboratory, HASL-300. 28th Ed., Vol. I. February. New York, NY.

U.S. Department of Energy, Nevada Operations Office. 2000. United States Nuclear Tests, July 1945 through September 1992, DOE/NV--209-REV 15. Las Vegas, NV.

U.S. Department of Energy, National Nuclear Security Administration Nevada Operations Office. 2002a. Industrial Sites Quality Assurance Project Plan, Rev. 3, DOE/NV--372--REV. 3. Las Vegas, NV.

U.S. Department of Energy, National Nuclear Security Administration Nevada Operations Office. 2002b. Nevada Test Site Orthophoto Site Atlas, DOE/NV/11718--604. Aerial photos acquired Summer 1998. Prepared by Bechtel Nevada. Las Vegas, NV. 
U.S. Department of Energy, National Nuclear Security Administration Nevada Site Office. 2004. Mud Pit Risk-Based Closure Strategy Report, Nevada Test Site, Nevada, Rev. 0, DOE/NV--991. Las Vegas, NV.

U.S. Department of Energy, National Nuclear Security Administration Nevada Site Office. 2006a. Closure Report for Corrective Action Units 530, 531, 532, 533, 534, 535: NTS Mud Pits, Nevada Test Site, Nevada, DOE/NV--1131. Las Vegas, NV.

U.S. Department of Energy, National Nuclear Security Administration Nevada Site Office. $2006 \mathrm{~b}$. Industrial Sites Project Establishment of Final Action Levels, Rev. 0, DOE/NV--1107. Las Vegas, NV.

U.S. Department of Energy, National Nuclear Security Administration Nevada Site Office. 2009. Corrective Action Investigation Plan for Corrective Action Unit 367: Area 10 Sedan, Ess and Uncle Unit Craters, Nevada Test Site, Nevada, Rev. 0, DOE/NV--1359. Las Vegas, NV.

U.S. Department of Energy, National Nuclear Security Administration Nevada Site Office. 2010a. An Aerial Radiological Survey of Nevada Test Site-Area 10, Corrective Action Unit 367, DOE/NV/25946--956. Prepared by C. Lyons for National Security Technologies, LLC. Las Vegas, NV: Remote Sensing Laboratory.

U.S. Department of Energy, National Nuclear Security Administration Nevada Site Office. 2010b. Nevada Test Site Radiological Control Manual, DOE/NV/25946--801, Rev. 1. Prepared by Radiological Control Managers’ Council. Las Vegas, NV.

U.S. Environmental Protection Agency. 1980. Prescribed Procedures for Measurement of Radioactivity in Drinking Water, EPA 600/4-80-032. Cincinnati, OH: Environmental Monitoring and Support Laboratory Office of Research and Development.

U.S. Environmental Protection Agency. 2006. Data Quality Assessment: Statistical Methods for Practitioners, EPA QA/G-9S, EPA/240/B-06/003. Washington DC: Office of Environmental Information.

U.S. Environmental Protection Agency. 2011. SW-846, Test Methods for Evaluating Solid Waste, Physical/Chemical Methods. As accessed at http://www.epa.gov/epawaste/hazard/testmethods/sw846/index.htm on 15 March.

Yu, C., A.J. Zielen, J.-J. Cheng, D.J. LePoire, E. Gnanapragasam, S. Kamboj, J. Arnish, A. Wallo III, W.A. Williams, and H. Peterson. 2001. User's Manual for RESRAD Version 6, ANL/EAD-4. Argonne, IL: Argonne National Laboratory, Environmental Assessment Division. (Version 6.5 released in October 2009.) 


\section{Appendix B}

\section{Data Assessment}


The DQA process is the scientific evaluation of the actual investigation results to determine whether the DQO criteria established in the CAU 367 CAIP (NNSA/NSO, 2009) were met and whether DQO decisions can be resolved at the desired level of confidence. The DQO process ensures that the right type, quality, and quantity of data will be available to support the resolution of those decisions at an appropriate level of confidence. Using both the DQO and DQA processes help ensure that DQO decisions are sound and defensible.

The DQA involves five steps that begin with a review of the DQOs and end with an answer to the DQO decisions. The five steps are briefly summarized as follows:

Step 1: Review DQOs and Sampling Design—Review the DQO process to provide context for analyzing the data. State the primary statistical hypotheses; confirm the limits on decision errors for committing false negative (Type I) or false positive (Type II) decision errors; and review any special features, potential problems, or deviations to the sampling design.

Step 2: Conduct a Preliminary Data Review_-Perform a preliminary data review by reviewing QA reports and inspecting the data both numerically and graphically, validating and verifying the data to ensure that the measurement systems performed in accordance with the criteria specified, and using the validated dataset to determine whether the quality of the data is satisfactory.

Step 3: Select the Test—Select the test based on the population of interest, population parameter, and hypotheses. Identify the key underlying assumptions that could cause a change in one of the DQO decisions.

Step 4: Verify the Assumptions-Perform tests of assumptions. If data are missing or are censored, determine the impact on DQO decision error.

Step 5: Draw Conclusions from the Data—Perform the calculations required for the test. 


\section{B.1.1 Review DQOs and Sampling Design}

This section contains a review of the DQO process presented in Appendix A of the CAU 367 CAIP (NNSA/NSO, 2009). The DQO decisions are presented with the DQO provisions to limit false negative or false positive decision errors. Special features, potential problems, or any deviations to the sampling design are also presented.

\section{B.1.1.1 Decision I}

The Decision I statement as presented in the CAU 367 CAIP for both the primary and other releases is as follows: "Is any COC present in environmental media within the CAS?" For the primary release, any sample location at which the 95 percent UCL of the mean TED exceeds 25 mrem/yr will be defined as containing a COC. The CAIP states that Decision I was resolved for the primary release. While contamination at levels exceeding the FAL is assumed to be present within the default contamination boundaries at each of the three crater CASs, this document resolves Decision I for the portion of the primary release beyond the default contamination boundaries.

For other release locations, the CAIP states that any analytical result for a COPC above a FAL will result in that COPC being designated as a COC. If a COC is not present, the investigation for that release is complete.

\section{B.1.1.1.1 DQO Provisions to Limit False Negative Decision Error}

A false negative decision error (determining that contamination above FALs is not present when it actually is) was controlled by meeting the following criteria:

1. a. For Decision I, having a high degree of confidence that sample locations selected will identify COCs if present anywhere within the CAS.

b. Maintenance of a false negative decision error rate of 0.05 (probabilistic sampling).

2. Having a high degree of confidence that analyses conducted will be sufficient to detect any COCs present in the samples.

3. Having a high degree of confidence that the dataset is of sufficient quality and completeness. 


\section{Criterion 1a}

To resolve Decision I for the primary release at CAU 367 (as stipulated in the DQOs), sample locations were selected based on ground-based radiological measurements and aerial surveys (BN, 1999; NNSA/NSO, 2010). Plots were established at the locations estimated to have the highest dose based on the highest survey readings outside each of the crater default contamination boundaries.

Sampling locations for other releases were selected at locations estimated to have the highest contamination levels based on the highest radiological survey results or visual indicators.

\section{$\underline{\text { Criterion 1b }}$}

Control of the false negative decision error for the probabilistic samples was accomplished by ensuring the following:

- The samples are collected from unbiased (i.e., random) locations.

- A sufficient sample size was collected.

- A false rejection rate of 0.05 was used in calculating minimum sample size and the 95 percent UCL (used in making DQO decisions for probabilistic sampling).

The sample aliquot locations within a sample plot were selected using the VSP software (PNNL, 2007). Each set of sample aliquot locations was derived using the random-start, systematic, triangular grid pattern for sample placement. Use of the VSP software permitted an unbiased, equal-weighted chance that any given location within the boundaries of the sample plot would be chosen. Although the TLD locations were not established at random locations (i.e., they were placed at the center of the sample plot), they provided an integrated, unbiased measurement of dose from the plot area. 
The minimum number of samples required for each sample plot was calculated for both the internal (soil samples) and external (TLD elements) dose samples. The minimum sample size was calculated using the following EPA sample size formula (EPA, 2006):

$$
n \geq \frac{S^{2}\left(Z_{.95}+Z_{.80}\right)^{2}}{(\mu-C)^{2}}+\frac{Z_{.95}^{2}}{2}
$$

where

$$
\begin{aligned}
& s=\text { standard deviation, } \\
& Z_{.95}=\text { z-score associated with the false negative rate of } 5 \text { percent, } \\
& Z_{.80}=\text { z-score associated with the false positive rate of } 20 \text { percent, } \\
& \mu=\text { dose level where false positive decision is not acceptable }(12.5 \mathrm{mrem} / \mathrm{yr}) \text {, and } \\
& \mathrm{C}=\text { FAL }(25 \mathrm{mrem} / \mathrm{yr}) .
\end{aligned}
$$

The use of this formula requires the input of basic statistical values associated with the sample data. Data from a minimum of three samples are required to calculate these statistical values, and as such, the least possible number of samples required to apply the formula is three. Therefore, in instances where the formula resulted in a value less than three, three is adopted as the minimum number of samples required. The results of the minimum sample size calculations and the number of samples collected are presented in Tables B.1-1 and B.1-2. As shown in these tables, the minimum number of soil and TLD samples was met or exceeded. The minimum sample size calculations were conducted as stipulated in the CAU 367 CAIP (NNSA/NSO, 2009) based on the following parameters:

- A false rejection rate of 0.05

- A false acceptance rate of 0.20

- The maximum acceptable gray region set to one-half the FAL (12.5 mrem/yr)

- The calculated standard deviation

Table B.1-1

Input Values and Minimum Number of Soil Samples Required for the Remote Work Area Exposure Scenario

(Page 1 of 2)

\begin{tabular}{||c|c|c|c||}
\hline Sample Plot & $\begin{array}{c}\text { Standard } \\
\text { Deviation }\end{array}$ & $\begin{array}{c}\text { Actual Number of } \\
\text { Samples Collected }\end{array}$ & $\begin{array}{c}\text { Minimum Number of } \\
\text { Samples Required }\end{array}$ \\
\hline \hline A & 0.027 & 4 & 3 \\
\hline B & 0.019 & 4 & 3 \\
\hline C & 0.005 & 4 & 3 \\
\hline D & 0.004 & 4 & 3 \\
\hline
\end{tabular}


Table B.1-1

Input Values and Minimum Number of Soil Samples Required for the Remote Work Area Exposure Scenario

(Page 2 of 2)

\begin{tabular}{|c|c|c|c|}
\hline Sample Plot & $\begin{array}{c}\text { Standard } \\
\text { Deviation }\end{array}$ & $\begin{array}{c}\text { Actual Number of } \\
\text { Samples Collected }\end{array}$ & $\begin{array}{c}\text { Minimum Number of } \\
\text { Samples Required }\end{array}$ \\
\hline \hline $\mathrm{E}$ & 0.020 & 5 & 3 \\
\hline $\mathrm{F}$ & 0.024 & 4 & 3 \\
\hline $\mathrm{G}$ & 0.041 & 4 & 3 \\
\hline $\mathrm{H}$ & 0.036 & 4 & 3 \\
\hline $\mathrm{J}$ & 0.014 & 5 & 3 \\
\hline $\mathrm{K}$ & 0.057 & 4 & 3 \\
\hline $\mathrm{L}$ & 0.024 & 5 & 3 \\
\hline $\mathrm{M}$ & 0.004 & 4 & 3 \\
\hline $\mathrm{N}$ & 0.017 & 4 & 3 \\
\hline $\mathrm{P}$ & 0.012 & 5 & 3 \\
\hline $\mathrm{Q}$ & 0.006 & 4 & 3 \\
\hline $\mathrm{R}$ & 0.050 & & 3 \\
\hline
\end{tabular}

Table B.1-2

Input Values and Minimum Number of TLD Samples Required for the Remote Work Area Exposure Scenario

(Page 1 of 3 )

\begin{tabular}{|c|c|c|c|c|}
\hline Sample Plot & $\begin{array}{c}\text { TLD } \\
\text { Location }\end{array}$ & $\begin{array}{c}\text { Standard } \\
\text { Deviation }\end{array}$ & $\begin{array}{c}\text { Actual Number of } \\
\text { Samples Collected }\end{array}$ & $\begin{array}{c}\text { Minimum Number of } \\
\text { Samples Required }\end{array}$ \\
\hline \hline A & AT42 & 0.883 & 3 & 3 \\
\hline B & AT41 & 0.125 & 3 & 3 \\
\hline C & AT44 & 0.251 & 3 & 3 \\
\hline D & AT45 & 0.319 & 3 & 3 \\
\hline E & AT33 & 0.311 & 3 & 3 \\
\hline F & AT34 & 0.709 & 3 & 3 \\
\hline G & AT36 & 0.416 & 3 & 3 \\
\hline H & AT39 & 0.308 & 3 & 3 \\
\hline J & AT24 & 0.314 & 3 & 3 \\
\hline K & AT55 & 1.125 & & 3 \\
\hline
\end{tabular}


Table B.1-2

Input Values and Minimum Number of TLD Samples Required for the Remote Work Area Exposure Scenario

(Page 2 of 3 )

\begin{tabular}{|c|c|c|c|c|}
\hline Sample Plot & $\begin{array}{c}\text { TLD } \\
\text { Location }\end{array}$ & $\begin{array}{l}\text { Standard } \\
\text { Deviation }\end{array}$ & $\begin{array}{l}\text { Actual Number of } \\
\text { Samples Collected }\end{array}$ & $\begin{array}{l}\text { Minimum Number of } \\
\text { Samples Required }\end{array}$ \\
\hline $\mathrm{L}$ & AT28 & 0.927 & 3 & 3 \\
\hline$M$ & AT30 & 0.325 & 3 & 3 \\
\hline $\mathrm{N}$ & AT01 & 0.930 & 3 & 3 \\
\hline $\mathrm{P}$ & AT02 & 0.286 & 3 & 3 \\
\hline Q & AT03 & 0.463 & 3 & 3 \\
\hline $\mathrm{R}$ & AT05 & 0.144 & 3 & 3 \\
\hline No plot & AT04 & 0.414 & 3 & 3 \\
\hline No plot & AT06 & 0.939 & 3 & 3 \\
\hline No plot & AT07 & 0.299 & 3 & 3 \\
\hline No plot & AT08 & 0.415 & 3 & 3 \\
\hline No plot & AT09 & 0.166 & 3 & 3 \\
\hline No plot & AT10 & 0.801 & 3 & 3 \\
\hline No plot & AT11 & 0.307 & 3 & 3 \\
\hline No plot & AT12 & 0.392 & 3 & 3 \\
\hline No plot & AT13 & 0.067 & 3 & 3 \\
\hline No plot & AT14 & 0.088 & 3 & 3 \\
\hline No plot & AT15 & 0.293 & 3 & 3 \\
\hline No plot & AT16 & 0.458 & 3 & 3 \\
\hline No plot & AT17 & 0.176 & 3 & 3 \\
\hline No plot & AT18 & 0.256 & 3 & 3 \\
\hline No plot & AT19 & 0.206 & 3 & 3 \\
\hline No plot & AT20 & 0.159 & 3 & 3 \\
\hline No plot & AT21 & 0.474 & 3 & 3 \\
\hline No plot & AT22 & 0.235 & 3 & 3 \\
\hline No plot & AT23 & 0.511 & 3 & 3 \\
\hline No plot & AT25 & 0.832 & 9 & 3 \\
\hline No plot & AT26 & 0.181 & 3 & 3 \\
\hline No plot & AT27 & 0.201 & 3 & 3 \\
\hline
\end{tabular}


Table B.1-2

Input Values and Minimum Number of TLD Samples Required for the Remote Work Area Exposure Scenario

(Page 3 of 3 )

\begin{tabular}{|c|c|c|c|c|}
\hline Sample Plot & $\begin{array}{c}\text { TLD } \\
\text { Location }\end{array}$ & $\begin{array}{l}\text { Standard } \\
\text { Deviation }\end{array}$ & $\begin{array}{l}\text { Actual Number of } \\
\text { Samples Collected }\end{array}$ & $\begin{array}{l}\text { Minimum Number of } \\
\text { Samples Required }\end{array}$ \\
\hline No plot & AT29 & 0.947 & 9 & 3 \\
\hline No plot & AT31 & 0.357 & 3 & 3 \\
\hline No plot & AT32 & 0.124 & 3 & 3 \\
\hline No plot & AT35 & 0.775 & 9 & 3 \\
\hline No plot & AT37 & 0.685 & 3 & 3 \\
\hline No plot & AT38 & 0.873 & 3 & 3 \\
\hline No plot & AT40 & 0.308 & 3 & 3 \\
\hline No plot & AT43 & 0.385 & 3 & 3 \\
\hline No plot & AT46 & 0.153 & 3 & 3 \\
\hline No plot & AT47 & 0.268 & 3 & 3 \\
\hline No plot & AT48 & 0.193 & 3 & 3 \\
\hline No plot & AT49 & 0.312 & 3 & 3 \\
\hline No plot & AT50 & 0.367 & 3 & 3 \\
\hline No plot & AT51 & 0.930 & 3 & 3 \\
\hline No plot & AT53 & 0.369 & 3 & 3 \\
\hline No plot & AT54 & 0.200 & 3 & 3 \\
\hline No plot & AT56 & 0.036 & 3 & 3 \\
\hline No plot & AT57 & 0.143 & 3 & 3 \\
\hline No plot & AT59 & 0.093 & 3 & 3 \\
\hline
\end{tabular}

\section{Criterion 2}

All samples were analyzed using the analytical methods listed in the CAU 367 CAIP (NNSA/NSO, 2009) for the primary release, Ess mud pit, and circle road samples. Specific analyses for other samples were based on the nature of the potential release as specified in the CAIP.

Sample results were assessed against the acceptance criterion for the DQI of sensitivity as defined in the Industrial Sites QAPP (NNSA/NV, 2002). The sensitivity acceptance criterion defined in the 
CAU 367 CAIP (NNSA/NSO, 2009) is that analytical detection limits will be less than the corresponding FAL . All detection limits were less than the FALs except for 1,2-dibromo-3-chloropropane in two samples. This chemical is used as a nematicide in agricultural crops. It was not detected in any sample and is not suspected to be present at this site. The inability to detect this chemical to levels below the FAL is not considered to affect the DQO decisions. Therefore, the DQI criterion for sensitivity was met.

\section{Criterion 3}

To satisfy the third criterion, the entire dataset, as well as individual sample results, was assessed against the acceptance criteria for the DQIs of precision, accuracy, comparability, completeness, and representativeness, as defined in the Industrial Sites QAPP (NNSA/NV, 2002). The DQI acceptance criteria are presented in Table 6-1 of the CAIP (NNSA/NSO, 2009). The individual DQI results are presented in the following subsections.

\section{$\underline{\text { Precision }}$}

Precision was evaluated as described in Section 6.2.3 of the CAIP. Table B.1-3 provides the precision analysis for radiological constituents that were qualified for precision.

Table B.1-3

Precision Measurements

\begin{tabular}{||c|c|c|c|c|}
\hline Contaminant & Analysis & $\begin{array}{c}\text { Number of } \\
\text { Measurements } \\
\text { Qualified }\end{array}$ & $\begin{array}{c}\text { Number of } \\
\text { Measurements } \\
\text { Performed }\end{array}$ & $\begin{array}{c}\text { Percent } \\
\text { within } \\
\text { Criteria }\end{array}$ \\
\hline \hline $\mathrm{U}-235$ & Uranium & 4 & 74 & 95 \\
\hline $\mathrm{Am}-241$ & Americium & 3 & 43 & 93 \\
\hline $\mathrm{Pu}-238$ & Plutonium & 15 & 88 & 83 \\
\hline $\mathrm{Sr}-90$ & Strontium & 15 & 74 & 80 \\
\hline
\end{tabular}

As shown in Table B.1-3, all contaminants qualified for precision met the criteria of 80 percent as specified in the CAIP. The precision evaluations were based on differences in laboratory duplicate sample results. High variability in the sample matrix suggests that discrete particles of contamination are present within the samples. Therefore, mixing will not produce homogeneity. This variability does not mean that the precision of the measurement is poor but that activities are variable within the 
samples. Therefore, when a duplicate sample is analyzed, the results can be significantly different depending on how many discrete particles are contained in each sample. As the precision rates for all constituents met the acceptance criteria for precision, the data are determined acceptable for the DQI of precision.

\section{Accuracy}

Accuracy was evaluated as described in Section 6.2.4 of the CAIP. The performance metric for assessing the DQI of accuracy on DQO decisions is that at least 80 percent of the sample results for each measured contaminant are not qualified for accuracy. As no sample results were qualified for accuracy, the dataset is considered to meet the DQI criterion for accuracy.

\section{$\underline{\text { Representativeness }}$}

The DQO process as identified in Appendix A of the CAIP was used to address sampling and analytical requirements for CAU 367. During this process, appropriate locations were selected that enabled the samples collected to be representative of the population parameters identified in the DQO (the most likely locations to contain contamination [judgmental sampling] or that represent contamination of the sample plot [probabilistic sampling] and locations that bound COCs) (Section A.2.1). The sampling locations identified in the Criterion 1 discussion meet this criterion. Therefore, the analytical data acquired during the CAU 367 CAI are considered representative of the population parameters.

\section{Comparability}

Field sampling, as described in the CAIP, was performed and documented in accordance with approved procedures that are comparable to standard industry practices. Approved analytical methods and procedures per DOE were used to analyze, report, and validate the data. These are comparable not only to other methods used in industry and government practices, but most importantly to other investigations conducted for the NNSS. Therefore, project datasets are considered comparable to other datasets generated using these same standardized DOE procedures, thereby meeting DQO requirements.

Also, standard, approved field and analytical methods ensured that data were appropriate for comparison to the investigation action levels specified in the CAIP. 


\section{Completeness}

The CAIP defines acceptable criteria for completeness to be that the dataset is sufficiently complete to be able to make the DQO decisions. This is initially evaluated as 80 percent of CAS-specific noncritical analytes identified in the CAIP having valid results. Rejected data (either qualified as rejected or data that failed the criterion of sensitivity) were not used in the resolution of DQO decisions and are not counted toward meeting the completeness acceptance criterion. As there were no rejected data except for the two 1,2-dibromo-3-chloropropane samples (that did not meet the sensitivity criterion), the dataset is considered to meet the DQI criterion for completeness.

\section{B.1.1.1.2 DQO Provisions to Limit False Positive Decision Error}

The false positive decision error was controlled by assessing the potential for false positive analytical results. Quality assurance/QC samples such as method blanks were used to determine whether a false positive analytical result may have occurred. This provision is evaluated during the data validation process, and appropriate qualifications are applied to the data when applicable. There were no data qualifications that would indicate a potential false positive result.

Proper decontamination of sampling equipment also minimized the potential for cross contamination that could lead to a false positive analytical result.

\section{B.1.1.2 Decision II}

Decision II as presented in the CAIP (NNSA/NSO, 2009) is as follows: "If a COC is present, is sufficient information available to evaluate potential CAAs?” Sufficient information is defined to include the following:

- The lateral and vertical extent of COC contamination

- The information needed to determine potential remediation waste types

- The information needed to evaluate the feasibility of remediation alternatives

As COCs were not detected outside the default contamination boundaries at CAU 367, Decision II sampling was not necessary. Decision II was resolved for the areas defined as the default contamination boundaries in the CAIP. Samples were collected from waste materials identified during the visual surveys that were determined to have a potential for containing PSM. These sample 
results were evaluated using the PSM criteria listed in Section 3.4 of the CAIP. This provided sufficient information to determine the PSM status of the wastes and to characterize the wastes for disposal.

\section{B.1.1.3 Sampling Design}

The CAIP (NNSA/NSO, 2009) stipulated that the following sampling processes would be implemented:

1. Judgmental sampling will be conducted at other releases and at locations of potential contamination identified during the CAI.

Result: Judgmental sampling was conducted at the Ess mud pit (CAS 10-09-03), the Circle Road area of interest, and PSM and potential release locations.

2. Sampling of the primary release will be conducted by a combination of judgmental and probabilistic sampling approaches.

Result: The locations of the sample plots were selected judgmentally and samples were collected within each plot probabilistically as described in Section A.2.0.

\section{B.1.2 Conduct a Preliminary Data Review}

A preliminary data review was conducted by reviewing QA reports and inspecting the data. Data were validated and verified to ensure that the measurement systems performed in accordance with the criteria specified. The validated dataset quality was found to be satisfactory.

\section{B.1.3 Select the Test and Identify Key Assumptions}

The test for making DQO decisions for radiological contamination was the comparison of the TED to the FAL of $25 \mathrm{mrem} / \mathrm{RW}$-yr. For other types of contamination, the test for making DQO decisions was the comparison of the maximum analyte result from each CAS to the corresponding FAL. The radiological FALs were based on an exposure duration to a site worker using the Remote Work Area exposure scenario.

The key assumptions that could impact a DQO decision are listed in Table B.1-4. 
Table B.1-4

\section{Key Assumptions}

\begin{tabular}{|c|c|}
\hline Exposure Scenario & $\begin{array}{l}\text { The potential for contamination exposure is limited to industrial workers who are not } \\
\text { assigned to the area as a regular work location and would be present at the site for } \\
\text { only short periods of time consistent with the Occasional Use Area exposure scenario. } \\
\text { These human receptors may be exposed to COPCs through ingestion and inhalation } \\
\text { of soil resulting from soil disturbance or direct contact. Workers may also be exposed } \\
\text { to radiation by performing activities in proximity to radioactive materials. }\end{array}$ \\
\hline Affected Media & Surface and shallow subsurface soil and debris, such as metal and concrete. \\
\hline $\begin{array}{l}\text { Location of } \\
\text { Contamination/Release } \\
\text { Points }\end{array}$ & $\begin{array}{l}\text { Surface soil ( } 0 \text { to } 5 \mathrm{~cm} \text { depth) with the potential for additional buried contaminated } \\
\text { soil horizons. }\end{array}$ \\
\hline Transport Mechanisms & $\begin{array}{l}\text { Surface water runoff may transport some contaminants within or outside the } \\
\text { boundaries of the CASs. Percolation of precipitation through subsurface media } \\
\text { serves as a minor driving force for vertical migration of contaminants. }\end{array}$ \\
\hline Preferential Pathways & Drainages and craters. \\
\hline $\begin{array}{l}\text { Lateral and Vertical } \\
\text { Extent of Contamination }\end{array}$ & $\begin{array}{l}\text { Contamination, if present, is expected to be contiguous to the release points. } \\
\text { Concentrations are expected to decrease with distance and depth from the source. } \\
\text { Groundwater contamination is not expected. Lateral and vertical extent of COC } \\
\text { contamination is assumed to be within the spatial boundaries of each CAS. }\end{array}$ \\
\hline Groundwater Impacts & None. \\
\hline Future Land Use & Nuclear Test Zone. \\
\hline Other DQO Assumption & $\begin{array}{l}\text { Subsurface contamination is present at the crater CASs due to the subsurface } \\
\text { detonations from the nuclear test devices. Surface contamination is present due to } \\
\text { atmospheric deposition from blowout material. The CSM includes the potential for } \\
\text { subsurface contamination from the atmospheric deposition of earlier tests that were } \\
\text { subsequently covered by the later tests. }\end{array}$ \\
\hline
\end{tabular}

\section{B.1.4 Verify the Assumptions}

The results of the investigation support the key assumptions identified in the CAU 367 DQOs and Table B.1-4 except as listed below:

- Exception: A site-specific evaluation of potentially exposed site workers (see Appendix C) indicates that tour escorts have the potential to be present on site for greater than 80 hours in a one-year time period (i.e., annual exposure duration postulated for the Occasional Use Area scenario). Although this is a very conservative estimate of the potential number of hours that a tour escort would spend at the site, the Occasional Use Area scenario would not adequately account for this potential annual exposure duration. Thus, the Remote Work Area exposure 
scenario was used to evaluate corrective actions at CAU 367 instead of the Occasional Use Area scenario.

- Impact: This exception has no impact on the CSM. The corrective action requirements at CAU 367 would not be affected by which of these exposure scenarios is used in the evaluation.

All data collected during the CAI supported the CSM with the exception noted above. The exception noted above did not invalidate the CSM presented in the CAIP (NNSA/NSO, 2009), nor did it necessitate revisions to the CSM.

\section{B.1.4.1 Other DQO Commitments}

The CAIP (NNSA/NSO, 2009) made the following commitments for sampling:

1. The Decision II sample plot locations must meet the criterion that at least one sample plot will be located within the 25-mrem/IA-yr boundary and at least one sample plot will be located outside this boundary (Section 4.2.2.1 of the CAIP).

Result: The requirement for one plot inside and one plot outside the 25-mrem/yr-IA boundary was met on all sampling vectors except the northwest vector. Although a sample plot was not established outside the 25-mrem/IA-yr boundary on the northwest vector, sufficient data were available to calculate the TED for this area. There are three TLDs not associated with sample plots located outside the 25-mrem/IA-yr boundary on the northwest vector. The TED was conservatively calculated at these locations by using a ratio of internal to external dose measured at the sample plot with the highest internal dose estimate.

2. With regard to buried contamination, if screening results are not significantly different (at least 50 percent difference between samples) from the surface results, it will be assumed that buried contamination does not exist, and only surface samples will be collected and submitted for analyses (Section A.9.1.3 of the CAIP).

Result: Modified screening criteria were used in determining the presence of buried contamination. Buried contamination was deemed present if the depth interval reading exceeded the FSL and there was a greater than 20 percent difference between the depth interval reading and the surface soil reading. The original screening criteria would have provided only a relative comparison of instrument readings without the determination of the presence or absence of contamination. Redefining the screening criteria allowed for a field-screening methodology that was more specific to the site through the use of site background measurements. 
3. A surface sample $(0$ to15 $\mathrm{cm})$ will be collected at the Ess mud pit (CAS 10-09-03) as well as a depth sample from just below the drilling mud and crater interface (Section A.9.4.1.1 of the CAIP).

Result: A sample at the interface was not collected because an interface could not be distinguished at $30 \mathrm{~cm}$ depth. This, however, does not impact the decisions made in this document because, based on previous investigations of mud pits on the NNSS, the physical properties of mud pit material limit significant vertical migration (Section A.4.3.3). Thus, there is no reason to suspect that the mud material within the Ess crater is different from mud pit mixtures historically used throughout the NNSS.

4. Sampling locations along Circle Road will be further refined using a FIDLER (or equivalent) radiation survey instrument to determine the location of highest radioactivity (Section A.9.4.1.3 of the CAIP).

Result: A FIDLER scan of the two areas was completed prior to sampling; however, the location of highest radioactivity at each area was not selected for sampling due to high-energy gamma interference (Section A.3.1.2.3). The two Circle Road sample locations were selected based on the 2009 Am-241 flyover data and ground-based radiological surveys.

5. Specific COPCs (and subsequently the analyses requested) will be determined for other potential releases based on the nature of the potential release (e.g., hydrocarbon stain, lead bricks) (Section 3.2 of the CAIP).

Result: Each of the PSM and potential release locations was evaluated for COPCs based on the source material (e.g., components, use, present condition). The analytical suite requested for these samples was tailored based on the evaluation.

\section{B.1.5 Draw Conclusions from the Data}

This section resolves the two DQO decisions for each of the CAU 367 CASs.

\section{B.1.5.1 Decision Rules for Decision I}

Decision Rule: If the population parameter of any COPC in the Decision I population of interest exceeds the corresponding FAL, then that contaminant is identified as a COC, and Decision II samples will be collected, else no further investigation is needed for that COPC in that population. 
Result: Although COCs were not identified at any sample location, COCs were assumed to be present within the default contamination boundaries, and some wastes were determined to be PSM based on process knowledge. Decision II was resolved as the extent of the default contamination boundaries and the PSM material that was removed during the CAI. No additional sampling was needed to resolve Decision II.

Decision Rule: If COC contamination is inconsistent with the CSM or extends beyond the spatial boundaries identified in Section A.6.2 of the CAIP (NNSA/NSO, 2009), then work will be suspended and the investigation strategy will be reconsidered, else the decision will be to continue sampling.

Result: The COC contamination was not found to be inconsistent with the CSM or extend beyond the spatial boundaries.

Decision Rule: If a COC exists at any CAS, then a corrective action will be determined, else no further action will be necessary.

Result: Because COCs were identified, corrective actions are required.

Decision Rule: If a waste is present that, if released, has the potential to cause the future contamination of site environmental media, then a corrective action will be determined, else no further action will be necessary.

Result: Wastes were identified as PSM and were removed under a corrective action.

\section{B.1.5.2 Decision Rules for Decision II}

Decision Rule: If the population parameter (the observed concentration of any COC) in the Decision II population of interest exceeds the corresponding FAL in any bounding direction, or potential remediation wastes have not been adequately defined, then additional samples will be collected to complete the Decision II evaluation, else the extent of the COC contamination has been defined.

Result: As COCs were not detected outside the default contamination boundaries at CAU 367, Decision II sampling was not necessary. Decision II was resolved for the areas defined as the default contamination boundaries in the CAIP (NNSA/NSO, 2009). 
Decision Rule: If valid analytical results are available for the waste characterization samples defined in Section A.9.0 of the CAIP, then the decision will be that sufficient information exists to determine potential remediation waste types and evaluate the feasibility of remediation alternatives, else collect additional waste characterization samples.

Result: Samples were collected from waste materials identified during the visual surveys that were determined to have a potential for containing PSM. These sample results were evaluated using the PSM criteria listed in Section 3.4 of the CAIP. This provided sufficient information to determine the PSM status of the wastes and to characterize the wastes for disposal. 


\section{B.2.0 References}

BN, see Bechtel Nevada.

Bechtel Nevada. 1999. An Aerial Radiological Survey of the Nevada Test Site, DOE/11718--324. Prepared for U.S. Department of Energy, Nevada Operations Office. Las Vegas, NV: Remote Sensing Laboratory.

EPA, see U.S. Environmental Protection Agency.

NNSA/NSO, see U.S. Department of Energy, National Nuclear Security Administration Nevada Site Office.

NNSA/NV, see U.S. Department of Energy, National Nuclear Security Administration Nevada Operations Office.

PNNL, see Pacific Northwest National Laboratory.

Pacific Northwest National Laboratory. 2007. Visual Sample Plan, Version 5.0 User's Guide, PNNL-16939. Richland, WA.

U.S. Department of Energy, National Nuclear Security Administration Nevada Operations Office. 2002. Industrial Sites Quality Assurance Project Plan, Nevada Test Site, Nevada, Rev. 3, DOE/NV--372. Las Vegas, NV.

U.S. Department of Energy, National Nuclear Security Administration Nevada Site Office. 2009. Corrective Action Investigation Plan for Corrective Action Unit 367: Area 10 Sedan, Ess and Uncle Unit Craters, Nevada Test Site, Nevada, Rev. 0, DOE/NV--1359. Las Vegas, NV.

U.S. Department of Energy, National Nuclear Security Administration Nevada Site Office. 2010. An Aerial Radiological Survey of Nevada Test Site-Area 10, Corrective Action Unit 367, DOE/NV/25946--956. Prepared by C. Lyons for National Security Technologies, LLC. Las Vegas, NV: Remote Sensing Laboratory.

U.S. Environmental Protection Agency. 2006. Data Quality Assessment: Statistical Methods for Practitioners, EPA QA/G-9S, EPA/240/B-06/003. Washington, DC: Office of Environmental Information. 


\section{Appendix C}

\section{Risk Assessment}


The risk-based corrective action (RBCA) process used to establish FALs is described in the Industrial Sites Project Establishment of Final Action Levels (NNSA/NSO, 2006). This process conforms with NAC Section 445A.227 (NAC, 2008a), which lists the requirements for sites with soil contamination. For the evaluation of corrective actions, NAC Section 445A.22705 (NAC, 2008b) requires the use of ASTM Method E1739 (ASTM, 1995) to "conduct an evaluation of the site, based on the risk it poses to public health and the environment, to determine the necessary remediation standards (i.e., FALs) or to establish that corrective action is not necessary."

The ASTM Method E1739 defines three tiers (or levels) of evaluation involving increasingly sophisticated analyses:

- Tier 1 evaluation-Sample results from source areas (highest concentrations) are compared to risk-based screening levels (RBSLs) based on generic (non-site-specific) conditions (i.e., the PALs established in the CAU 367 CAIP [NNSA/NSO, 2009]). The FALs may then be established as the Tier 1 action levels, or the FALs may be calculated using a Tier 2 evaluation.

- Tier 2 evaluation-A Tier 2 evaluation is conducted by calculating Tier 2 site-specific target levels (SSTLs) using site-specific information as inputs to the same or similar methodology used to calculate Tier 1 action levels. The Tier 2 SSTLs are then compared to individual sample results from reasonable points of exposure (as opposed to the source areas as is done in Tier 1) on a point-by-point basis.

- Tier 3 evaluation-A Tier 3 evaluation is conducted by calculating Tier 3 SSTLs on the basis of more sophisticated risk analyses using methodologies described in Method E1739 that consider site-, pathway-, and receptor-specific parameters.

The RBCA process stipulated in the Industrial Sites Project Establishment of Final Action Levels (NNSA/NSO, 2006) is summarized in Figure C.1-1. 


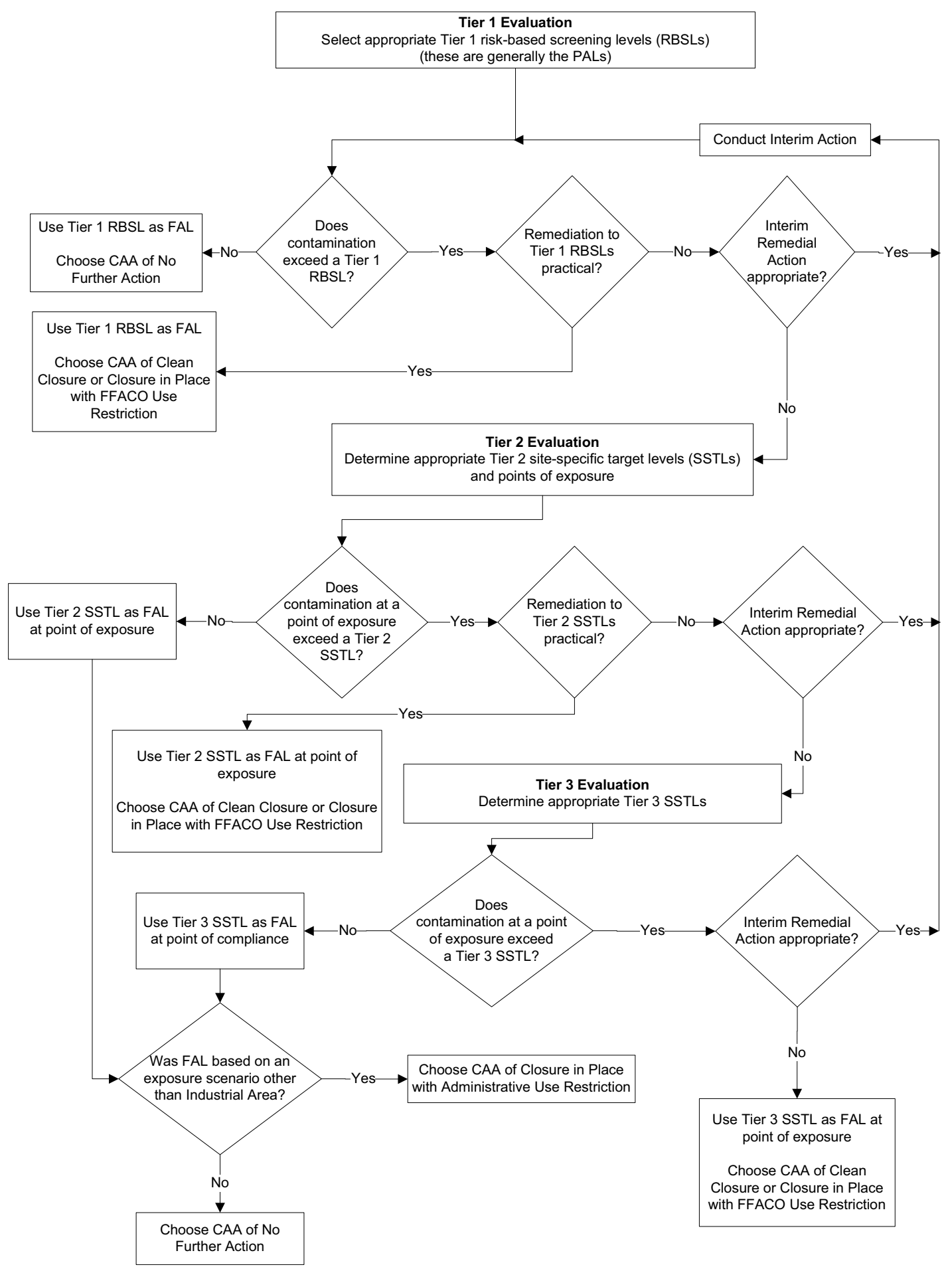

(ASTM, 1995)

Figure C.1-1

Risk-Based Corrective Action Decision Process 


\section{C.1.1 Scenario}

Corrective Action Unit 367, Area 10 Sedan, Ess and Uncle Unit Craters, comprises the following four CASs within Area 10 of the NNSS:

- 10-09-03, Mud Pit

- 10-45-01, U-10h Crater (Sedan)

- 10-45-02, Ess Crater Site

- 10-45-03, Uncle Crater Site

The primary release is associated with the three crater CASs and includes the areas affected by the surface release of radioactivity associated with the Uncle, Ess, and Sedan underground nuclear tests. Each of the tests resulted in the formation of a crater surrounded by mounds of ejected soil. None of the three craters are fenced or posted for radiological control.

The mud pits at CAS 10-09-03 are not fenced or posted for radiological control.

The Circle Road area of interest consists of a stretch of road northwest of the Sedan crater where aerial radiological surveys suggested elevated radiological readings. Periodic road maintenance activities have been conducted along this road since the Sedan test was conducted. This area is not fenced or posted for radiological control.

None of the debris item locations at CAU 367 are fenced or posted for radiological control.

\section{C.1.2 Site Assessment}

The primary release was investigated by collecting radiological dose measurements and soil samples. These data were used to calculate TED to workers. The maximum average TED at the three crater CASs to which a site worker under an Industrial Area scenario would potentially be exposed was calculated at 90.6 mrem/IA-yr. Refer to Section A.3.2.3 for details on calculation of the TED.

The maximum TED at the mud pit CAS to which a site worker under an Industrial Area scenario would potentially be exposed was calculated at 1.78 mrem/IA-yr (Section A.4.3.2). The maximum average TED at the Circle Road area of interest to which a site worker under an Industrial Area scenario would potentially be exposed was calculated at 17.8 mrem/IA-yr (Section A.4.2.2). 


\section{C.1.3 Site Classification and Initial Response Action}

Page $\mathrm{C}-4$ of $\mathrm{C}-14$

The four major site classifications listed in Table 1 of the ASTM Standard are (1) immediate threat to human health, safety, and the environment; (2) short-term (0 to 2 years) threat to human health, safety, and the environment; (3) long-term (greater than 2 years) threat to human health, safety, or the environment; and (4) no demonstrated long-term threats.

Based on the CAI, the CAU 367 releases do not present an immediate threat to human health, safety, and the environment; therefore, no interim response actions are necessary at these sites. Under current site conditions, CAU 367 poses a long-term threat to human health, safety, and the environment due to the presence of surface and subsurface radiological contamination. Thus, the three crater CASs, 10-45-01, 10-45-02, and 10-45-03, are considered Classification 3 sites as defined in ASTM Method E1739. The two mud pits in CAS 10-09-03 (Ess and Akbar mud pits) are considered Classification 4 sites.

\section{C.1.4 Development of Tier 1 Lookup Table of RBSLs}

Tier 1 RBSLs are defined as the PALs. The PALs were established during the DQO process and are listed in the CAIP (NNSA/NSO, 2009). The PALs represent a conservative estimate of risk, are preliminary in nature, and are generally used for screening purposes. Although the PALs are not intended to be used as FALs, FALs may be defined as the Tier 1 RBSL (i.e., PAL) value if implementing a corrective action based on the Tier 1 RBSL would be appropriate.

The PALs for radiological contaminants are defined by the dose limit of $25 \mathrm{mrem} / \mathrm{yr}$ using the Industrial Area exposure scenario. The Industrial Area scenario assumes that a full-time industrial worker is present at a particular location for his entire career for10 hr/day, 225 day/yr for a duration of 25 years). The dose-based Tier 1 RBSL of $25 \mathrm{mrem} / \mathrm{yr}$ for the primary release is implemented by calculating the dose a site worker would receive if exposed to the site contaminants over an annual exposure period of 2,250 hours. 
The Tier 1 RBSLs for chemical contaminants are the following PALs as defined in the CAIP:

- EPA Region 9 Risk-Based Preliminary Remediation Goals (PRGs) for Industrial Soils (EPA, 2010).

- Background concentrations for RCRA metals will be evaluated when natural background exceeds the PAL, as is often the case with arsenic. Background is considered the mean plus two times the standard deviation of the mean based on data published in Mineral and Energy Resource Assessment of the Nellis Air Force Range (NBMG, 1998; Moore, 1999).

- For COPCs without established PRGs, a protocol similar to EPA Region 9 will be used to establish an action level; otherwise, an established PRG from another EPA region may be chosen.

\section{C.1.5 Exposure Pathway Evaluation}

At all four CASs, the DQOs stated that site workers would only be exposed to COCs through oral ingestion, inhalation, or dermal contact (absorption) of soil or mud material due to inadvertent disturbance of these materials, or irradiation by radioactive materials. The potential exposure pathways would be through worker contact with the contaminated soil or mud material currently present at these sites. The elapsed time since the releases and depth to groundwater support the selection and evaluation of only surface and shallow subsurface contact as the complete exposure pathways. Ingestion of groundwater is not considered a significant exposure pathway.

\section{C.1.6 Comparison of Site Conditions with Tier 1 RBSLs}

For radiological contamination, the Industrial Area exposure time of 2,250 hr/yr was used to calculate site radiological doses (i.e., TED). These values were compared to the Tier 1 RBSL (25 mrem/IA-yr). For the primary release contaminants at the locations listed in Table C.1-1, the 95 percent UCL TED exceeded the Tier 1 RBSL. The radiological doses calculated at the other release sites (i.e., Circle Road and CAS 10-09-03), did not exceed the Tier 1 RBSL.

For chemical contamination, the individual analytical results were compared to the EPA PRGs (established as the Tier 1 RBSLs) for chemical constituents. With one exception, the RBSLs were not exceeded at any of the other release locations. Lead was detected in the soil at a concentration of $5,200 \mathrm{mg} / \mathrm{kg}$ at the location of a deteriorated lead-acid battery. This concentration exceeds the Tier 1 RBSL for lead of $800 \mathrm{mg} / \mathrm{kg}$. 
Table C.1-1

Primary Release Locations Where TED Exceeds the Tier 1 RBSL

\begin{tabular}{|c|c|c|c|}
\hline $\begin{array}{l}\text { Sample } \\
\text { Plot }\end{array}$ & $\begin{array}{c}\text { TLD } \\
\text { Location }\end{array}$ & $\begin{array}{l}\text { Average TED } \\
\text { (mrem/IA-yr) }\end{array}$ & $\begin{array}{l}\text { 95\% UCL TED } \\
\text { (mrem/IA-yr) }\end{array}$ \\
\hline$A$ & AT42 & 53.3 & 63.4 \\
\hline$B$ & AT41 & 34 & 35.5 \\
\hline$E$ & AT33 & 57.4 & 61 \\
\hline $\mathrm{F}$ & AT34 & 64.5 & 72.7 \\
\hline G & AT36 & 35.7 & 40.7 \\
\hline $\mathrm{J}$ & AT24 & 54.7 & 58.3 \\
\hline K & AT55 & 90.6 & 95.5 \\
\hline L & AT28 & 67.8 & 78.4 \\
\hline $\mathrm{N}$ & AT01 & 40.5 & 51.1 \\
\hline$P$ & AT02 & 26.8 & 30.1 \\
\hline No plot & AT10 & 26.6 & 36.3 \\
\hline No plot & AT11 & 24.7 & 28.3 \\
\hline No plot & AT12 & 27.1 & 31.8 \\
\hline No plot & AT20 & 25.5 & 27.4 \\
\hline No plot & AT21 & 25.6 & 31.3 \\
\hline No plot & AT25 & 50.1 & 53.7 \\
\hline No plot & AT26 & 52.8 & 54.9 \\
\hline No plot & AT29 & 54.8 & 59 \\
\hline No plot & AT35 & 50.3 & 53.7 \\
\hline No plot & AT37 & 28.6 & 36.9 \\
\hline No plot & AT38 & 22.0 & 32.5 \\
\hline No plot & AT43 & 27.9 & 32.6 \\
\hline No plot & AT49 & 26.3 & 30 \\
\hline No plot & AT51 & 49.8 & 60.9 \\
\hline
\end{tabular}




\section{C.1.7 Evaluation of Tier 1 Results}

Page C-7 of C-14

The NNSA/NSO determined that remediation to the RBSL at the primary release locations is not appropriate. The risk to receptors from contaminants at CAU 367 is due to chronic exposure to radionuclides (i.e., receiving a dose over time). Therefore, the risk to a receptor is directly related to the amount of time a receptor is exposed to the contaminants. A review of the current and projected use of the land at CAU 367 determined that workers may be present at these sites for only a limited number of hours per year (see Section C.1.10) and that it is not reasonable to assume that any worker would be present at this site for 2,250 hr/yr (DOE, 1996). Therefore, it was determined to conduct a Tier 2 evaluation for the three crater CASs.

\section{C.1.8 Tier 1 Remedial Action Evaluation}

As detailed in Section A.4.4.2, the Tier 1 RBSL for lead was exceeded in soil at the location of a deteriorated lead-acid battery. The battery as well as surrounding soil was removed, and verification samples were collected. The results of the verification samples did not exceed the RBSLs, so a Tier 2 evaluation was not necessary.

\section{C.1.9 Tier 2 Evaluation}

No additional data were needed to complete a Tier 2 evaluation.

\section{C.1.10 Development of Tier 2 Table of SSTLS}

The Tier 2 action levels are typically compared to contaminant values that are representative of areas in which an individual or population may come in contact with a COC originating from a CAS. This concept is illustrated as follows in the EPA guidance on human risk assessments at superfund sites (Part A of the EPA Human Health Evaluation Manual) (EPA, 1989):

The area over which the activity is expected to occur should be considered when averaging the monitoring data for a hot spot. For example, averaging soil data over an area the size of a residential backyard (e.g., an eighth of an acre) may be most appropriate for evaluating residential soil pathways.

When evaluating industrial receptors, the area to which an industrial worker is exposed may be much larger than that for a residential receptor. For a site that is limited to industrial use, the receptor would 
be a site worker, and patterns of employee activity would be used to estimate the area to which the receptor is exposed. This estimation can be very complicated, as industrial workers may perform routine activities at many locations where only a portion of these locations may be contaminated.

A more practical measure of integrated risk to radiological dose for an industrial worker is to calculate the portion of total work time that the worker is in proximity to elevated radioactivity and therefore able to receive a dose. For example, site workers may have routine activities that require them to be at a work location for 22 day/yr. If the work schedule was $10 \mathrm{hr} / \mathrm{day}$ - or 2,250 hr/yr (i.e., as is used for the Industrial Area exposure scenario) — the site worker would receive 10 percent of the potential annual dose that they would otherwise receive if exposed to the radioactive location for the entire work year.

For the development of radiological Tier 2 SSTLs, the annual dose limit for a site worker is $25 \mathrm{mrem} / \mathrm{yr}$ (the same as was used for the Tier 1 evaluation). The Tier 2 evaluation is based on a receptor exposure time that is more specific to actual site conditions. The maximum potential exposure time for the most exposed worker at the three crater CASs was determined based on an evaluation of current and reasonable future activities that may be conducted at these sites.

There are no permanent utilities at CAU 367, nor are any expected to be installed in the foreseeable future. As a result, the regular maintenance of utilities, such as water lines and electrical conduits, was not included as a current or future site activity in this evaluation. Activities on the NNSS are strictly controlled through a formal work control process. This process requires facility managers to authorize all work activities that take place on the land or at the facilities within their purview. The facility manager responsible for the area of CAU 367 identified the general types of work activities that are currently conducted at the site to include fencing/posting inspection and maintenance work, site tours to the Sedan crater viewing area, and demarcation activities. Site activities that may occur in the future were identified by assessing tasks related to maintenance of existing infrastructure and long-term stewardship of the site (e.g., inspection and maintenance of UR signs). In order to estimate the amount of time a site worker might spend conducting current or future activities, the NNSA/NSO and/or management and operating contractor departments responsible for these activities were consulted. 
Under the current land use at CAU 367, the following workers were identified as being potentially exposed to site contamination:

- Inspection and Maintenance Worker. The FFACO UR requires an annual inspection to ensure that the postings are present, legible, and in good condition. It was estimated that a site worker would spend a maximum of $10 \mathrm{hr} / \mathrm{yr}$ at the three crater CASs performing these duties.

- Tour Escort. Due to its historical significance, the Sedan crater is a regular stop on NNSS tours provided to the public and government personnel. Although the tour escorts vary, for estimation purposes, it was assumed that one person escorts all the tours that visit the Sedan crater over a one-year period. It was also assumed that the escort spends approximately 1 hour at the Sedan crater during each visit and that eight tours are provided each month. Thus, the maximum number of hours a tour escort would spend at the Sedan crater is $96 \mathrm{hr} / \mathrm{yr}$.

- Demarcation Worker. Although the three crater CASs are not posted for radiological control, a small fenced Contamination Area is located directly west of the Sedan crater off the east shoulder of Circle Road. Radiological readings are collected at this location on a periodic basis to confirm the existing postings. It was conservatively estimated that such readings would be required on an annual basis and that a site worker involved in collecting the readings could potentially spend up to 8 hours in the vicinity of this fenced area.

- Air Sampling Station Maintenance Worker. A tritium and air particulate monitoring station, is located near the Sedan crater. As part of the NNSS-wide monitoring program, site workers visit this station every week to download data and perform required maintenance on the unit (e.g., pump repair, filter replacement). The site workers typically spend 0.5 hour at the Sedan monitoring station each visit. Although the site workers may vary from week to week, it was conservatively assumed that one person conducts the weekly visits over a one-year period. Thus, the maximum number of hours an air sampler worker would spend at CAU 367 is $26 \mathrm{hr} / \mathrm{yr}$.

- Trespasser. This would include workers or individuals who do not have a specific work assignment at CAU 367, but may inadvertently walk across the site and come in contact with site contamination. This is assumed to be an infrequent occurrence so a potential exposure of less than one day per year per person is assumed. Thus, the maximum number of hours a trespasser would spend at CAU 367 is $8 \mathrm{hr} / \mathrm{yr}$.

- Road Maintenance Worker. Periodic road maintenance is conducted on the paved roadway that passes through the northwest portion of CAU 367 around the Sedan crater (Circle Road). Road maintenance activities may include road patching, grading, resurfacing, shoulder work, and repaving. It was assumed that a complete repaving of the roadway would involve the greatest number of potential exposure hours. Circle Road was repaved in 2009 as part of a larger road-paving project at the NNSS. It was estimated that site workers completed roughly $3 \mathrm{mi}$ of Circle Road in 7 days (assuming that each worker worked 10 hours a day). A 1.5-mi section of Circle Road northwest of the Sedan crater that transects the contamination 
plume (as shown in the 2009 aerial survey) was chosen to estimate future site worker exposure. It was estimated that a road maintenance worker would be present at Circle Road for 4 days on a full-time basis (10 hr/day) once during the year. Thus, the maximum number of hours a road maintenance worker would spend at CAU 367 is $40 \mathrm{hr} / \mathrm{yr}$.

As shown in Table C.1-2 under the current land use at the three crater CASs, the individual likely to spend the most time at CAU 367 would be the tour escort, who may spend up to 96 hours at the visitors platform at the Sedan crater in a year. However, due to the low dose rate measured at the visitors platform at Sedan (most likely due to the clean fill material used in constructing the visitors platform and parking area), the tour escort has the potential to receive a dose of $0.53 \mathrm{mrem} / \mathrm{yr}$ in 96 hours spent at the platform. The road maintenance worker was determined to have the potential to receive the highest dose over a one-year time period, although this worker is estimated to spend only 40 hours at the work location. This is because the maximum calculated dose rate along Circle Road is higher than that at the Sedan visitors platform. Thus, for CAU 367, the most exposed individual was determined to be the road maintenance worker, who can expect to receive an estimated dose of $0.57 \mathrm{mrem} / \mathrm{yr}$ when involved in road maintenance activities.

Table C.1-2

Maximum Potential Dose for Potentially Exposed Workers at CAU 367

\begin{tabular}{|c|c|c|c|}
\hline Worker & $\begin{array}{c}\text { Maximum Dose at } \\
\text { Work-Specific Location } \\
\text { (mrem/IA-yr) }\end{array}$ & $\begin{array}{c}\text { Estimated } \\
\text { Exposure Time } \\
\text { (hr/yr) }\end{array}$ & $\begin{array}{c}\text { Maximum } \\
\text { Potential Dose } \\
\text { (mrem/yr) }\end{array}$ \\
\hline \hline Inspection and Maintenance & 95.5 & 10 & 0.42 \\
\hline Tour Escort & 12.5 & 96 & 0.53 \\
\hline Demarcation & 31.8 & 8 & 0.11 \\
\hline Air Sampling Station Maintenance & 28.3 & 26 & 0.33 \\
\hline Trespasser & 95.5 & 8 & 0.34 \\
\hline Road Maintenance & 31.8 & 40 & 0.57 \\
\hline
\end{tabular}

Because a tour escort could potentially be present at CAU 367 for $96 \mathrm{hr} / \mathrm{yr}$, the Occasional Use Area exposure scenario, which is based on a maximum exposure of $80 \mathrm{hr} / \mathrm{yr}$, does not adequately define the anticipated land use of CAU 367. Instead, the Remote Work Area exposure scenario, which is based on a maximum of $336 \mathrm{hr} / \mathrm{yr}$, better represents anticipated site conditions and was used in developing the FAL for CAU 367. 


\section{C.1.11 Comparison of Site Conditions with Tier 2 Table SSTLs}

Implementation of the dose-based Tier 2 SSTL of $25 \mathrm{mrem} / \mathrm{yr}$ for the primary release radionuclides based on the Remote Work Area exposure scenario was accomplished by calculating dose (i.e., TED) at the primary release locations over an exposure period of 336 hours (8 hr/day, 42 day/yr). The TEDs calculated using the Remote Work Area exposure scenario were then compared to the Tier 2 SSTL of 25 mrem/RW-yr. As shown in Table A.3-9 and Figure A.3-6, all of the Remote Work Area exposure scenario TED values at CAU 367 are less than the Tier 2 SSTL of 25 mrem/RW-yr.

\section{C.1.12 Tier 2 Remedial Action Evaluation}

The maximum calculated TED under the Remote Work Area scenario is $14.3 \mathrm{mrem} / \mathrm{RW}$-yr at sample plot K (Table A.3-9). Based on the average TED value, a receptor would have to be exposed to this location for 621 hours to receive a dose of 25 mrem. Based on the Tier 2 comparison, the surface soil at the three crater CASs does not pose an unacceptable risk to human health and the environment, and no corrective action is required. It is assumed, however, that subsurface contamination present at each crater exceeds the Tier 2 SSTL due to the prompt injection of radionuclides into the subsurface from the test. Because the radiological FAL was established as the Tier 2 SSTL, a Tier 3 evaluation was not necessary. 


\section{C.2.0 Recommendations}

Because the TED values associated with the primary release at CAU 367 were less than the corresponding FALs at the three crater CASs, it was determined that surface and shallow subsurface soil contamination at these locations does not warrant corrective actions. However, deeper subsurface contamination produced by the underground detonations exists at the three crater CASs which is assumed to exceed the exceed the FAL of 25 mrem/RW-yr. Therefore, a corrective action was necessary to address the subsurface contamination at the three crater CASs.

The corrective action of closure in place with URs was implemented at each of the three crater CASs. The FFACO UR boundary surrounds each crater and the associated ejecta mounds and will be posted with signs to prevent inadvertent access by site workers and visitors.

The FAL was based on site worker exposure to CAS surface soils at $336 \mathrm{hr} / \mathrm{yr}$. Should the land use at the three crater CASs change and industrial land use activities are proposed to be conducted at any of these CASs, a site worker could potentially be exposed to a dose exceeding $25 \mathrm{mrem} / \mathrm{yr}$. Therefore, an administrative UR was established at CAU 367 as a BMP. The areas that provide sufficient dose to potentially cause a full-time industrial worker to receive an annual dose exceeding 25 mrem are conservatively defined in Section A.3.3 and illustrated in Figure A.3-8. The administrative UR boundary restricts future industrial land use without prior NNSA/NSO and NDEP approval.

The corrective actions for CAU 367 are based on the assumptions that activities on the NNSS will be limited to those that are industrial in nature and that the NNSS will maintain controlled access (i.e., restricted public access and residential use). Should the future land use of the NNSS change in such a way that these assumptions are no longer valid, additional evaluation may be necessary.

The FFACO URs for the three crater CASs and the administrative UR for CAU 367 are recorded in the FFACO database, NNSA/NSO Facility Information Management System, and the NNSA/NSO CAU/CAS files. These URs are included in Appendix D. 


\section{C.3.0 References}

ASTM, see ASTM International.

ASTM International. 1995 (reapproved 2010). Standard Guide for Risk-Based Corrective Action Applied at Petroleum Release Sites, ASTM E1739 - 95(2010)e1. West Conshohocken, PA.

DOE, see U.S. Department of Energy.

EPA, see U.S. Environmental Protection Agency.

Moore, J., Science Applications International Corporation. 1999. Memorandum to M. Todd (SAIC), “Background Concentrations for NTS and TTR Soil Samples,” 3 February. Las Vegas, NV.

NAC, see Nevada Administrative Code.

NBMG, see Nevada Bureau of Mines and Geology.

NNSA/NSO, see U.S. Department of Energy, National Nuclear Security Administration Nevada Site Office.

Nevada Administrative Code. 2008a. NAC 445A.227, “Contamination of Soil: Order by Director for Corrective Action; Factors To Be Considered in Determining Whether Corrective Action Required.” Carson City, NV. As accessed at http://www.leg.state.nv.us/nac on 15 March 2011.

Nevada Administrative Code. 2008b. NAC 445A.22705, “Contamination of Soil: Evaluation of Site by Owner or Operator; Review of Evaluation by Division.” Carson City, NV. As accessed at http://www.leg.state.nv.us/nac on 15 March 2011.

Nevada Bureau of Mines and Geology. 1998. Mineral and Energy Resource Assessment of the Nellis Air Force Range, Open-File Report 98-1. Reno, NV.

U.S. Department of Energy. 1996. Final Environmental Impact Statement for the Nevada Test Site and Off-Site Locations in the State of Nevada, DOE/EIS-0243. August. Las Vegas, NV: U.S. Department of Energy, Nevada Site Office.

U.S. Department of Energy, National Nuclear Security Administration Nevada Site Office. 2006. Industrial Sites Project Establishment of Final Action Levels, Rev. 0, DOE/NV--1107. Las Vegas, NV.

U.S. Department of Energy, National Nuclear Security Administration Nevada Site Office. 2009. Corrective Action Investigation Plan for Corrective Action Unit 367: Area 10 Sedan, Ess and Uncle Unit Craters, Nevada Test Site, Nevada, Rev. 0, DOE/NV--1359. Las Vegas, NV. 
U.S. Environmental Protection Agency. 1989. Risk Assessment Guidance for Superfund, Volume I, Human Health Evaluation Manual (Part A), EPA/540/1-89/002. Washington, DC: Office of Emergency and Remedial Response.

U.S. Environmental Protection Agency. 2010. Region 9: Superfund, Regional Screening Table (Formerly PRGs), Screening Levels for Chemical Contaminants. As accessed at http://www.epa.gov/region09/superfund/prg on 15 March 2011. Prepared by EPA Office of Superfund and Oak Ridge National Laboratory. 


\section{Attachment C-1}

Derivation of Residual Radioactive Material Guidelines for Radionuclides in Soil at CAU 367 Area 10 Sedan, Ess and Uncle Unit Craters Nevada National Security Site, Nevada (10 Pages) 


\section{Derivation of Residual Radioactive Material Guidelines for Radionuclides in Soil at Corrective Action Unit (CAU) 367, Area 10, Sedan, Ess and Uncle Unit Craters Nevada National Security Site, Nevada}

\section{$\underline{\text { Introduction }}$}

This appendix promulgates tables of Residual Radioactive Material Guidelines (RRMGs) for the Industrial Area, Remote Work Area, and Occasional Use Area exposure scenarios, for use in the evaluation of Soils Project sites. These exposure scenarios are described in the document Industrial Sites Project Establishment of Final Action Levels (NNSA/NSO, 2006). Two sets of RRMGs were calculated for each of the three exposure scenarios: one set using only the inhalation and ingestion pathways (e.g., internal dose), and one set that added the external gamma pathway (e.g., internal and external dose). The second set is needed to evaluate "other release" soil samples where thermoluminescent dosimeters (TLDs) were not emplaced to measure the external dose.

\section{Background}

The Industrial Sites Project Establishment of Final Action Levels (NNSA/NSO, 2006), provides a Nevada Division of Environmental Protection (NDEP)-approved process for the derivation of soil sampling final action levels that are congruent with the risk-based corrective action process. This document is used by the Navarro-Intera, LLC (N-I), Soils Project as well.

The Residual Radioactive (RESRAD) computer code, version 6.5 (Yu et al., 2001), and the guidance provided in NNSA/NSO (2006) were used to derive RRMGs for use in the Soils Project. The RRMGs are radionuclide-specific values for radioactivity in surface soils, expressed in units of picocuries per gram ( $\mathrm{pCi} / \mathrm{g}$ ). A soil sample with a radionuclide concentration that is equal to the RRMG value for that radionuclide would present a potential dose of 25 millirem per year (mrem/yr) to a receptor under the conditions described in the exposure scenario. When more than one radionuclide is present, the potential dose must be evaluated by summing the fractions for each radionuclide (i.e., the measured concentration divided by the RRMG for the radionuclide). The resultant sum of the fractions value is then multiplied by 25.0 to obtain an estimate of the dose.

The RRMGs are specific to a particular exposure scenario. The dose estimates obtained from the use of RRMGs are valid only when the assumptions provided in the exposure scenario for the intended land-use hold true. In most cases at the Nevada National Security Site (NNSS), the Industrial Area exposure scenario is quite conservative and is bounding for most anticipated future land uses.

A recent revision to 10 Code of Federal Regulations (CFR) Part 835 (CFR, 2011) had adopted new, more sophisticated, dosimetric models and new dosimetric terms. Internal dose is now to be expressed in terms of the Committed Effective Dose (CED), and International Commission on Radiological Protection (ICRP) 72 dose conversion factors are to be used. 


\section{Methods}

Calculations were performed using the RESRAD code, version 6.5 (Yu et al., 2001). The ICRP 72 dose conversion factors were used. The RESRAD input parameters were verified and checkprinted.

The radionuclide niobium ( $\mathrm{Nb}$ )-94 was previously added to the RRMGs to accommodate work in Area 25 that is related to the Nuclear Rocket Development Station (NRDS). The radionuclides silver (Ag)-108m, curium (Cm)-243, and Cm-244 were recently detected on one or more Soils Project sites, and RRMGs were calculated to demonstrate that their contribution to the total effective dose (TED) is negligible.

The RESRAD calculations have identified that for all radionuclides evaluated, with one exception: The maximum potential dose occurs at time-zero. The RRMGs provided in this memorandum do reflect those for time-zero. The exception previously mentioned is the radionuclide thorium (Th)-232, which has several daughters with short half-lives. Because the daughter activity "grows in," and because RRMGs include the contributions from daughters, the maximum potential dose for Th-232 actually occurs at 10.21 years. A RRMG for Th-232 at 10.21 years was not selected, and the RRMG for time-zero was used, for the following reasons:

- RESRAD suggests a set of RRMGs for use when the overall total dose is at its maximum. Considering the contributions from all radionuclide contaminants of potential concern (COPCs), this would be at time-zero.

- The additional dose from the in-growth of Th-232 daughters is offset by the radioactive decay of other radionuclides that would be present (e.g., cesium [Cs]-137).

- The additional dose from the in-growth of Th-232 daughters is very small when compared to the basic dose limit of $25 \mathrm{mrem} / \mathrm{yr}$. For example, if Th-232 were found at a concentration of $100 \mathrm{pCi} / \mathrm{g}$, the increase in potential dose from time-zero to 10.21 years would only be 0.52 millirem (mrem). To date, Th-232 has only been seen on Soils Project sites at environmental levels of about 1.5 to $3 \mathrm{pCi} / \mathrm{g}$.

\section{Assumptions and Default Parameters}

Appendix B to DOE/NV--1107 (NNSA/NSO, 2006) lists the RESRAD code variables (i.e., input parameters) for the three exposure scenarios. These pre-determined values were used to calculate the RRMGs, with a few exceptions as described in Table 1.

\section{$\underline{\text { Results }}$}

The RRMGs are presented in Tables 2 to 7 . The abbreviation "RRMG" in each of the six tables includes a subscript to indicate the scenario and the exposure pathways that are activated. When referencing a set of RRMGs, the subscripts should be included to avoid confusion and a potential misapplication of the RRMGs. 
Table 1: RESRAD Input Parameters

\begin{tabular}{|c|c|c|c|c|c|}
\hline Item \# & $\begin{array}{l}\text { RESRAD } \\
\text { Parameter }\end{array}$ & $\begin{array}{l}\text { Industrial } \\
\text { Area }\end{array}$ & $\begin{array}{c}\text { Remote } \\
\text { Work Area }\end{array}$ & $\begin{array}{l}\text { Occasional } \\
\text { Use Area }\end{array}$ & Explanation \\
\hline 1 & $\begin{array}{l}\text { Area of } \mathrm{CZ} \\
\quad\left(\mathrm{m}^{2}\right)\end{array}$ & \multicolumn{3}{|c|}{1,000} & $\begin{array}{l}\text { Appendix B states "Site Specific." Previously, } 100 \mathrm{~m}^{2} \text { was selected to conform to } \\
\text { the maximum area of contamination limitation in DOE Order } 5400.5 \text { (DOE, 1993). } \\
\text { Going forward, } 1,000 \mathrm{~m}^{2} \text { has been selected to add conservativism and realism to the } \\
\text { RRMGs. The } 1,000 \mathrm{~m}^{2} \text { RRMGs will be applied to } 100 \mathrm{~m}^{2} \text { evaluation areas. }\end{array}$ \\
\hline 2 & $\begin{array}{l}\text { Thickness of CZ } \\
(\mathrm{m})\end{array}$ & \multicolumn{3}{|c|}{0.05} & $\begin{array}{l}\text { Appendix B states "Site Specific." This depth encompasses the bulk of the } \\
\text { potential contamination and includes the maximum concentration. }\end{array}$ \\
\hline 3 & Cover Depth & \multicolumn{3}{|c|}{0.00} & $\begin{array}{l}\text { Appendix B states "Site Specific." Cover depth only affects the time delay before } \\
\text { contamination becomes available for erosion and airborne suspension. Increasing } \\
\text { the cover depth, in some cases, may lead to lower dose estimates. }\end{array}$ \\
\hline 4 & $\begin{array}{l}\text { Precipitation } \\
(\mathrm{m} / \mathrm{yr})\end{array}$ & \multicolumn{3}{|c|}{0.144} & $\begin{array}{l}\text { Appendix B states “Site Specific.” The selected value is the average annual rainfall } \\
\text { as recorded at Camp Desert Rock. }\end{array}$ \\
\hline 5 & Indoor Time Fraction & [0.1712] & {$[0.0256]$} & 0 & $\begin{array}{l}\text { The stated value was } 0 \text {, conservatively assuming no time is spent indoors. The new } \\
\text { value more accurately reflects the Industrial Area scenario in which } 66 \% \text { of the time } \\
\text { is spent indoors. } \\
\qquad\left(\frac{2250 \text { hrs on }- \text { site }}{8760 \text { hrs in a year }}\right) 0.6666 \text { indoors }=0.1712 \\
\text { The same correction was made for the Remote Work Area scenario. }\end{array}$ \\
\hline 6 & $\begin{array}{l}\text { Soil Ingestion Rate } \\
\text { (g/yr) }\end{array}$ & [43.43] & 20.2 & 4.8 & $\begin{array}{l}\text { The stated value was 108, assuming that all time is spent outdoors under a } 480 \\
\text { mg/day soil ingestion rate. The new value more accurately reflects the soil ingestion } \\
\text { rate of } 193 \text { mg/day when both indoor and outdoor time fractions are considered. } \\
\text { Refer to page } 14 \text { of DOE/NV--1107 (NNSA/NSO, 2006). }\end{array}$ \\
\hline 7 & $\begin{array}{l}\text { Indoor Dust } \\
\text { Filtration Factor }\end{array}$ & {$[0.4]$} & [0.4] & 1 & $\begin{array}{l}\text { This is the RESRAD default value and is appropriate as, under the Industrial Area } \\
\text { and Remote Work Area scenarios, } 66 \% \text { of the time is spent indoors. }\end{array}$ \\
\hline 8 & $\begin{array}{l}\text { Shielding Factor } \\
\text { External Gamma }\end{array}$ & [0.7] & [0.7] & 1 & $\begin{array}{l}\text { This is the RESRAD default value and is appropriate as, under the Industrial Area } \\
\text { and Remote Work Area scenarios, } 66 \% \text { of the time is spent indoors. }\end{array}$ \\
\hline 9 & $\begin{array}{l}\text { Pathway } 1- \\
\text { External Gamma }\end{array}$ & Suppressed & Suppressed & Suppressed & $\begin{array}{l}\text { In general, external dose at Soils Projects will be evaluated via TLDs or direct } \\
\text { measurement with a dose-rate meter. Soil samples and RRMGs are used to } \\
\text { determine the internal dose component only. The pathway was activated for the } \\
\text { second set of RRMGs for each scenario to allow the evaluation of biased sample } \\
\text { locations where TLDs were not emplaced. }\end{array}$ \\
\hline
\end{tabular}

Note 1: Items 1-4 above are site-specific default values that were selected for the Soils Project.

Note 2: Table B.1-1 in Appendix B contains several errors. The bold and bracketed values are corrections to those values.
$C Z=$ Contamination zone
g/yr = Grams per year
$m / y r=$ Meters per year
mg/day = Milligrams per day

$m^{2}=$ Square meter 
Table 2: Soils Project - Industrial Area Exposure Scenario - Internal Dose Only

\begin{tabular}{|c|c|}
\hline Radionuclide & $\begin{array}{c}\text { RRMG }_{(\mathrm{IA}-\mathrm{I})} \\
(\mathrm{pCi} / \mathrm{g})\end{array}$ \\
\hline Ag-108m & $2.737 \mathrm{E}+06$ \\
\hline Am-241 & $2.816 \mathrm{E}+03$ \\
\hline Cm-243 & $3.852 \mathrm{E}+03$ \\
\hline Cm-244 & $4.735 \mathrm{E}+03$ \\
\hline Co-60 & $5.513 \mathrm{E}+05$ \\
\hline Cs-137 & $1.409 \mathrm{E}+05$ \\
\hline Eu-152 & $1.177 \mathrm{E}+06$ \\
\hline Eu-154 & $8.469 \mathrm{E}+05$ \\
\hline Eu-155 & $5.588 \mathrm{E}+06$ \\
\hline Nb-94 & $3.499 \mathrm{E}+06$ \\
\hline Pu-238 & $2.423 \mathrm{E}+03$ \\
\hline Pu-239/240 & $2.215 \mathrm{E}+03$ \\
\hline Sr-90 & $5.947 \mathrm{E}+04$ \\
\hline Th-232 & $2.274 \mathrm{E}+03$ \\
\hline $\mathrm{U}-234$ & $1.960 \mathrm{E}+04$ \\
\hline $\mathrm{U}-235$ & $2.089 \mathrm{E}+04$ \\
\hline $\mathrm{U}-238$ & $2.120 \mathrm{E}+04$ \\
\hline
\end{tabular}

A soil sample at this RRMG value would present an internal dose potential of 25 mrem under the Industrial Area exposure scenario. 
Table 3: Soils Project - Industrial Area Exposure Scenario - Internal \& External Dose

\begin{tabular}{|c|c|}
\hline Radionuclide & $\begin{array}{c}\mathbf{R R M G}_{(\mathbf{I A}-\mathrm{IE})} \\
(\mathrm{pCi} / \mathrm{g})\end{array}$ \\
\hline Ag-108m & $9.281 \mathrm{E}+01$ \\
\hline Am-241 & $1.503 \mathrm{E}+03$ \\
\hline $\mathrm{Cm}-243$ & $3.155 \mathrm{E}+02$ \\
\hline $\mathrm{Cm}-244$ & $4.713 \mathrm{E}+03$ \\
\hline Co-60 & $1.833 \mathrm{E}+01$ \\
\hline Cs-137 & $7.290 \mathrm{E}+01$ \\
\hline Eu-152 & $3.826 \mathrm{E}+01$ \\
\hline Eu-154 & $3.571 \mathrm{E}+01$ \\
\hline Eu-155 & $9.583 \mathrm{E}+02$ \\
\hline $\mathrm{Nb}-94$ & $9.653 \mathrm{E}+01$ \\
\hline $\mathrm{Pu}-238$ & $2.416 \mathrm{E}+03$ \\
\hline $\mathrm{Pu}-239 / 240$ & $2.207 \mathrm{E}+03$ \\
\hline Sr-90 & $7.714 \mathrm{E}+03$ \\
\hline Th-232 & $5.067 \mathrm{E}+02$ \\
\hline U-234 & $1.865 \mathrm{E}+04$ \\
\hline U-235 & $2.555 \mathrm{E}+02$ \\
\hline U-238 & $1.423 \mathrm{E}+03$ \\
\hline
\end{tabular}

A soil sample at this RRMG value would present a TED potential of 25 mrem under the Industrial Area exposure scenario. 
Table 4: Soils Project - Remote Work Area Exposure Scenario - Internal Dose Only

\begin{tabular}{|c|c|}
\hline Radionuclide & $\begin{array}{c}\text { RRMG }_{(\mathbf{R W A}-\mathbf{I})} \\
(\mathrm{pCi} / \mathrm{g})\end{array}$ \\
\hline Ag-108m & $3.389 \mathrm{E}+07$ \\
\hline Am-241 & $1.612 \mathrm{E}+04$ \\
\hline $\mathrm{Cm}-243$ & $2.223 \mathrm{E}+04$ \\
\hline $\mathrm{Cm}-244$ & $2.716 \mathrm{E}+04$ \\
\hline Co-60 & $7.229 \mathrm{E}+06$ \\
\hline Cs-137 & $1.955 \mathrm{E}+06$ \\
\hline Eu-152 & $1.324 \mathrm{E}+07$ \\
\hline Eu-154 & $9.741 \mathrm{E}+06$ \\
\hline Eu-155 & $6.645 \mathrm{E}+07$ \\
\hline $\mathrm{Nb}-94$ & $3.966 \mathrm{E}+07$ \\
\hline $\mathrm{Pu}-238$ & $1.388 \mathrm{E}+04$ \\
\hline $\mathrm{Pu}-239 / 240$ & $1.268 \mathrm{E}+04$ \\
\hline Sr-90 & $8.075 \mathrm{E}+05$ \\
\hline Th-232 & $1.341 \mathrm{E}+04$ \\
\hline U-234 & $1.379 \mathrm{E}+05$ \\
\hline U-235 & $1.496 \mathrm{E}+05$ \\
\hline U-238 & $1.554 \mathrm{E}+05$ \\
\hline
\end{tabular}

A soil sample at this RRMG value would present an internal dose potential of 25 mrem under the Remote Work Area exposure scenario. 
Table 5: Soils Project - Remote Work Area Exposure Scenario - Internal \& External Dose

\begin{tabular}{|c|c|}
\hline Radionuclide & $\begin{array}{c}\mathbf{R R M G}_{(\mathbf{R W A}-\mathrm{IE})} \\
(\mathrm{pCi} / \mathrm{g})\end{array}$ \\
\hline Ag-108m & $6.204 \mathrm{E}+02$ \\
\hline Am-241 & $9.239 \mathrm{E}+03$ \\
\hline Cm-243 & $2.083 \mathrm{E}+03$ \\
\hline Cm-244 & $2.715 \mathrm{E}+04$ \\
\hline Co-60 & $1.225 \mathrm{E}+02$ \\
\hline Cs-137 & $4.874 \mathrm{E}+02$ \\
\hline Eu-152 & $2.557 \mathrm{E}+02$ \\
\hline Eu-154 & $2.387 \mathrm{E}+02$ \\
\hline Eu-155 & $6.406 \mathrm{E}+03$ \\
\hline Nb-94 & $6.452 \mathrm{E}+02$ \\
\hline Pu-238 & $1.390 \mathrm{E}+04$ \\
\hline Pu-239/240 & $1.269 \mathrm{E}+04$ \\
\hline Sr-90 & $5.522 \mathrm{E}+04$ \\
\hline Th-232 & $3.292 \mathrm{E}+03$ \\
\hline $\mathrm{U}-234$ & $1.314 \mathrm{E}+05$ \\
\hline $\mathrm{U}-235$ & $1.709 \mathrm{E}+03$ \\
\hline $\mathrm{U}-238$ & $9.572 \mathrm{E}+03$ \\
\hline
\end{tabular}

A soil sample at this RRMG value would present a TED potential of 25 mrem under the Remote Work Area exposure scenario. 
Table 6: Soils Project - Occasional Use Area Exposure Scenario - Internal Dose Only

\begin{tabular}{|c|c|}
\hline Radionuclide & $\begin{array}{c}\text { RRMG }_{\text {(OUA-I) }} \\
(\mathrm{pCi} / \mathrm{g})\end{array}$ \\
\hline Ag-108m & $2.762 \mathrm{E}+08$ \\
\hline Am-241 & $4.555 \mathrm{E}+04$ \\
\hline $\mathrm{Cm}-243$ & $6.307 \mathrm{E}+04$ \\
\hline $\mathrm{Cm}-244$ & $7.68 \mathrm{E}+04$ \\
\hline Co-60 & $7.421 \mathrm{E}+07$ \\
\hline Cs-137 & $2.756 \mathrm{E}+07$ \\
\hline Eu-152 & $8.174 \mathrm{E}+07$ \\
\hline Eu-154 & $6.353 \mathrm{E}+07$ \\
\hline Eu-155 & $4.751 \mathrm{E}+08$ \\
\hline $\mathrm{Nb}-94$ & $2.492 \mathrm{E}+08$ \\
\hline $\mathrm{Pu}-238$ & $3.922 \mathrm{E}+04$ \\
\hline $\mathrm{Pu}-239 / 240$ & $3.582 \mathrm{E}+04$ \\
\hline Sr-90 & $9.949 \mathrm{E}+06$ \\
\hline Th-232 & $3.852 \mathrm{E}+04$ \\
\hline U-234 & $4.470 \mathrm{E}+05$ \\
\hline U-235 & $4.922 \mathrm{E}+05$ \\
\hline U-238 & $3.361 E+05$ \\
\hline
\end{tabular}

A soil sample at this RRMG value would present an internal dose potential of 25 mrem under the Occasional Use Area exposure scenario. 
Table 7: Soils Project - Occasional Use Area Exposure Scenario - Internal \& External Dose

\begin{tabular}{|c|c|}
\hline Radionuclide & $\begin{array}{c}\mathbf{R R M G}_{(\text {OUA-IE })} \\
(\mathrm{pCi} / \mathrm{g})\end{array}$ \\
\hline Ag-108m & $2.087 \mathrm{E}+03$ \\
\hline Am-241 & $2.797 \mathrm{E}+04$ \\
\hline $\mathrm{Cm}-243$ & $6.886 \mathrm{E}+03$ \\
\hline $\mathrm{Cm}-244$ & $7.653 \mathrm{E}+04$ \\
\hline Co-60 & $4.122 \mathrm{E}+02$ \\
\hline Cs-137 & $1.640 \mathrm{E}+03$ \\
\hline Eu-152 & $8.604 \mathrm{E}+02$ \\
\hline Eu-154 & $8.031 \mathrm{E}+02$ \\
\hline Eu-155 & $2.156 \mathrm{E}+04$ \\
\hline $\mathrm{Nb}-94$ & $2.171 \mathrm{E}+03$ \\
\hline $\mathrm{Pu}-238$ & $3.915 \mathrm{E}+04$ \\
\hline $\mathrm{Pu}-239 / 240$ & $3.573 \mathrm{E}+04$ \\
\hline Sr-90 & $1.955 \mathrm{E}+05$ \\
\hline Th-232 & $1.062 \mathrm{E}+04$ \\
\hline U-234 & $4.252 \mathrm{E}+05$ \\
\hline U-235 & $5.749 \mathrm{E}+03$ \\
\hline U-238 & $3.219 \mathrm{E}+04$ \\
\hline
\end{tabular}

A soil sample at this RRMG value would present a TED potential of 25 mrem under the Occasional Use Area exposure scenario. 


\section{$\underline{\text { References }}$}

CFR, see Code of Federal Regulations.

Code of Federal Regulations. 2011. Title 10 CFR Part 835, "Occupational Radiation Protection.” Washington, DC: U.S. Government Printing Office.

DOE, see U.S. Department of Energy.

NNSA/NSO, see U.S. Department of Energy, National Nuclear Security Administration Nevada Site Office.

U.S. Department of Energy. 1993. Radiation Protection of the Public and the Environment, DOE Order 5400.5, Change 2. Washington, DC.

U.S. Department of Energy, National Nuclear Security Administration Nevada Site Office. 2006. Industrial Sites Project Establishment of Final Action Levels, Rev. 0, DOE/NV--1107. Las Vegas, NV.

U.S. Department of Energy, National Nuclear Security Administration Nevada Site Office. 2009. Corrective Action Investigation Plan for Corrective Action Unit 372: Area 20 Cabriolet/Palanquin Unit Craters, Nevada Test Site, Nevada, Rev. 0, DOE/NV--1322. Las Vegas, NV.

Yu, C., A.J. Zielen, J.J. Cheng, D.J. LePoire, E. Gnanapragasam, S. Kamboj, J. Arnish, A. Wallo III, W.A. Williams, and H. Peterson. 2001. User's Manual for RESRAD Version 6, ANL/EAD-4. Argonne, IL: Argonne National Laboratory, Environmental Assessment Division. (Version 6.5 released in October 2009.) 


\section{Appendix D}

\section{Closure Activity Summary (Use Restrictions)}




\section{D.1.0 Closure Activity Summary}

The following sections document closure activities completed at the three crater CASs (10-45-01, 10-45-02, 10-45-03), CAS 10-09-03, and identified PSM locations.

\section{D.1.1 Crater CASs}

The three crater CASs at CAU 367-CASs 10-45-01 (Sedan crater), 10-45-02 (Ess crater), and 10-45-03 (Uncle crater) — were investigated as one primary release. Evaluation of the CAI data indicates that the radiological dose from surface and shallow subsurface contamination at these sites does not exceed the FAL of 25 mrem/yr under a Remote Work Area exposure scenario. However, subsurface contamination resulting from the underground detonations that exceeds the radiological FALs is assumed to be present at the three CASs. In order to address the subsurface contamination, a corrective action of closure in place with a UR was implemented at each of the three CASs at CAU 367. The FFACO UR boundary at each crater encircles the default contamination boundary, which includes the crater and associated ejecta mounds surrounding the crater (Attachment D-2).

In accordance with the Industrial Sites Project Establishment of Final Action Levels (NNSA/NSO, 2006), an administrative UR was established to prevent more intensive use of the site in the future (Attachment D-2). The FFACO UR boundaries for the three crater CASs and the CAU 367 administrative UR boundary are recorded in the FFACO database, NNSA/NSO Facility Information Management System, and the NNSA/NSO CAU/CAS files. Permission to conduct any activities within the FFACO UR boundary at any of the crater CASs requires prior approval from NDEP. Permission to conduct the following restricted activities within the administrative UR boundary requires prior approval from NDEP:

- Full-time work assignments

- $\quad$ Construction of facilities

- Any activity that would result in a worker being assigned to a regular work station within the UR area

The established FFACO UR boundary for each crater CAS and the administrative UR boundary for CAU 367 is defined by the coordinates listed in the FFACO UR forms in Attachment D-2. 


\section{D.1.2 CAS 10-09-03}

Evaluation of the CAI data from the Ess mud pit (CAS 10-09-03) indicate that no chemical COCs are present at the mud pit and that the dose is below 25 mrem/IA-yr. Thus, no corrective action is required at the Ess mud pit. Due to the location of the mud pit within the Ess crater, this CAS is encompassed by the FFACO UR boundary established at CAS 10-45-02 (Ess crater) and within the administrative UR boundary established for CAU 367.

The Akbar mud pit (CAS 10-09-03) met the required criteria for closure (see Section A.4.3.2) under the NNSS mud pit closure strategy. As a result, no further action is required, and site closure is considered complete.

\section{D.1.3 Potential Source Material Locations}

A limited soil removal corrective action was implemented at the location of a lead-acid battery release. Based on completion of this correction action and the results of verification samples, no additional corrective action is required at CAU 367, and site closure is considered complete.

Three deteriorated batteries and an empty paint can were removed from CAU 367 as part of site closure activities. Although corrective action was not required for non-PSM items, items that were easily handled were removed and disposed of as a BMP. These items included empty drums, empty 5-gallon containers, and small construction rubble piles (concrete, rebar, fence posts). Additional detail on PSM closure activities is presented in Section A.4.4. 


\section{D.2.0 References}

NNSA/NSO, see U.S. Department of Energy, National Nuclear Security Administration Nevada Site Office.

U.S. Department of Energy, National Nuclear Security Administration Nevada Site Office. 2006. Industrial Sites Project Establishment of Final Action Levels, Rev. 0, DOE/NV--1107. Las Vegas, NV. 


\section{Attachment D-1}

\section{Waste Disposition Documentation}

(5 Pages) 


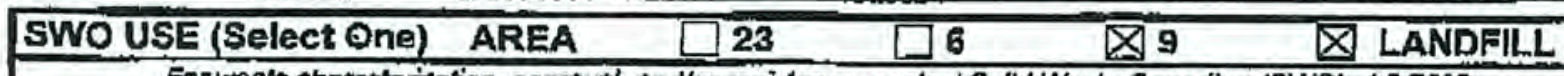

For wasfe charectorization, spproval, and/or assiotance, contact Solld Wasto Operation (SWO) at 5-789s.

\section{REQUIRED: WASTE GERERATOR INFORAATION}

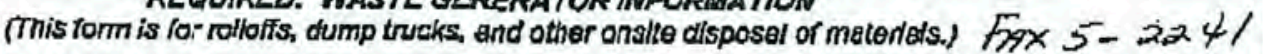

Weste Generator: Mark Haser (Nl. WO) (M/S - NSF 176) (Fax 5-22A1) Phone Number: (0)5-2124; $(0) 488-0150$ Location / Origin: NTS-Mercury. Building 23-153 - Bulk debrls collected in 20 yd3 roll-off (Container 10 153R10). Wasto Category: (chack ani) Waste Type: $\square$ NTS (Gheck one) $\square$ NTS

$\square$ Commencial
cial

$\square$ Asbestos Com

Q Industrial

Pollution Preyention Catogory: (check ono) $\triangle$ Envirumental management

Pollution Prevention Catogory: (check ono) $\square$ cleamup

Mothod of Characterization: (choek one) \& Sampling \& Analysis

国 FFACO-onsite

FFACO-Offsite

Defense Projects

$\square$ WAC Exception $\square$ Higtoric DOE/NV

Prohilyted Waste at all threo NTS landfills:

Additional Prohlbltad Wast at the Araa 9 U10C Landill:

Rad/oactlva waste; RCRA waste; Hazardous waste; Free liqudds, PCBs obovo TSCA rogulatory levels, and Medical wastes (needles, sharps. bloody clothing).

at tha Araas UToc Landili:

Sewage Sludge, Animal carcatses, Wel gerbage (food wasto); and Friable asbestos

\section{REQUIRED: WASTE CONTENTS ALLOWABLE WASTES}

Check oll ollowable wastes that are contained within this losd:

NOTE: Waste disposal at the Area 8 Hydrocarbon Landfill must have come Into contact with petroleum hydrocarbone or coolants, such as: gasoline (no benzene, lead); jet fuel; diasel fuel; lubricants and hydraulics; kerosene; asphaltic petroleum hydrocarbon: and ethyleno olycol,
Acceptable waste at any NTS landfilis
$\square$ Asphalt $\otimes$ Metal
⿶ Wood
Q Paper
$\square$ Seil
$\square$ Rocks/unaltered geologic materials
$\square$ Rubber (excluding tres)
区 Plastic $\square$ Wira $\square$ Cable $\square$ cloth $\square$ insulation (non-Asbestosform)
Additlonal wasto accepted at the Area 23 Mercury Landifi $\square$ Omce Waste
$\square$ Asbestos
$\square$ Friable
$\square$ Non-Friable (comlact SWo if regulated load)
Quantity?
Q Empty conlainers
$\square$ Demolition debris
$\square$ Cement \& concreter

Additional wasto aceapitad at the Aroa 9 U10o Landfill!

$\square$ Non-filable asbestos
$\square$ Light ballasts (contact swo) $\square$ Drained automobiles and military vehifles
$\square$ Hydrocarbons (contect swo) $\square$ Other

Solld fractions from sandiollhwater

Deconned Underground and Above Ground Tanks

Additional waste accepted at the Area 6 Hydrocarbon Landinl:
$\square$ Septic aludge
Plants
$\square$ Rags
soll
[D Drained fuel titers (gan \& diesel)
$\square$ Sludge from sand/oll/water separators
REQUIRED; WASTE LENERATOR SICNATURE
Crushed non-zeme plated oil filters $\mathrm{FCE}$ s below 50 parts per million

Initlale: (If Inithaled, no radiologlcal clearance is neceserary.)

The above mentioned waste was gonerated ourside of a Controlled Waste Nlanagarnet knowlodgo, dogu not eontain radiologlcal materlals.

To the best of my knowiadga, the watta described abovo containg anly those materla site. I nave verified this through tha waste characterization method identified alusva i prohibitad and allowable waste toems. I have contactod Praparty Mananament and ho 185. approved for dlasposel in the landinil.

Print Name: Mark Heser

Signature:

$$
12=8-2010
$$
Date: $11 / 4 / N$

Note: "Food waste, office trash and animal carcaseses do not require a rediologicat cleas must have gigned removal certification statement with Load Verifieation."

SWO USE ONLY

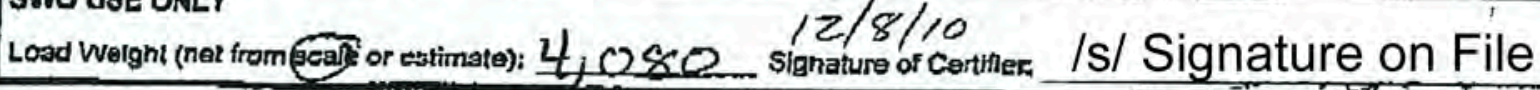

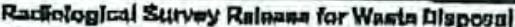
RCT tomials

- Thle aomalnediload motete the chitaria for no addad ra This containeriloted anepite the Eriterle for Rudcon Mahual Tabin 4,3 roleses Itmita.

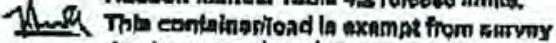
due to precoes lonoudodso and arigin. arenatuRL:/s/ Signature on Filebare of $2=1,19$ 
\begin{tabular}{|llllll}
\hline SWO USE (Select One) & AREA & $\square 23$ & $\square 6$ & Q $9 / 10 \mathrm{C}$ & LANDFILL
\end{tabular}

For waste characterization, approval, and/or assistance, contact Solid Waste Operation (SWO) at 5-7898. REQUIRED: WASTE GERERATOR INFORMATION

(This form is for rolloffs, dump trucks, and other onsite disposal of materials.)

Waste Generator: Nicole Nastanski (NI, WO) (M/S-NSF167) (Fax 5-2025) Phone Number: (0)5-1839

Location / Origin: CAU 367, Area 10 near Sedan. Container \# 36701 - Bulk Industrial Debris

Waste Category: (check one)

Waste Type: $\square$ NTS

(check one) $\square$ Non-Putrescible

Pollution Prevention Category: (check one)

Pollution Prevention Category: (check one)

Method of Characterization: (check one)

$\square$ Commercial

Industrial

$\square$ Putrescrible

$\triangle$ FFACO-onsite

$\square$ Asbestos Containing Material

FFACO-offsite

$\triangle$ Environmental management

Clean-Up

Prohibited Waste at all three

Sampling \& Analysis

$\square$ Defense Projects

$\square$ Routine

NTS landfills:

Additional Prohibited Waste

at the Area 9 U10C Landfill:

Radioactive waste; RCRA waste; Hazardous waste; Free liquids, PCBs above TSCA regulatory
levels, and Medical wastes (needles, sharps, bloody chothing)

(needles, sharps, bloody clothing).

Sewage Sludge, Animal carcasses, Wet garbage (food waste); and Friable asbestos

\section{REQUIRED: WASTE CONTENTS ALLOWABLE WASTES}

Check all allowable wastes that are contained within this load:

NOTE: Waste disposal at the Area 6 Hydrocarbon Landfill must have come into contact with petroleum hydrocarbons or coolants, such as: gasoline (no benzene, lead); jet fuel; diesel fuel; lubricants and hydraulics; kerosene; asphaltic
petroleum hydrocarbon; and ethylene glycol.

\section{Acceptable waste at any NTS landfill: \\ $\otimes$ Metal \\ $\square$ Wood \\ Q Soil \\ $\square$ Rocks / unaltered geologic materials}

NN

$\square$ Cloth

$\square$ Rubber (excluding tires)

E Empty containers

$\square$ Insulation (non-Asbestosform)

$\square$ Demolition debris

$\square$ Cement \& concrete

Additional waste accepted at tho Area 23 Mercury Landfill: $\square$ Office Waste

$\square$ Asbestos

$\square$ Friable

$\square$ Non-Friable (contact SWO if regulated load)

$\square$ Food Waste

Quantity:

Additional waste accopted at the Area 9 U10e Landfill:

$\square$ Drained automobiles and military vehicles

Hydrocarbons (contact SWO)

Other

Solid fractions from sand/oil/water

$\square$ Deconned Underground and Above Ground Tanks
Additional waste accepted at the Area 6 Hydrocarbon Landfill:
\begin{tabular}{lll}
$\square$ Septic sludge & $\square$ Rags \\
$\square$ Plants & $\square$ Soil & $\square$ Drained fuel filters (gas \& diesel) \\
\hline
\end{tabular} REQUIRED: WASTE GENERATOR SIGMAT
$\square$ Crushed non-teme plated oil filters $\square$ PCBs below 50 parts per million

Initials: (if initialed, no radiologlcal clearance is necessary.) The above mentloned waste was generated outside of a Controlled Waste Management Area (CWMA) and to the best of my
knowledge, does not contain radiological materlals.

To the best of my knowledge, the waste described above contains only those materia site. I have verified thls through the waste characterization mothod identified above, prohibited and allowable wasto itoms. I have contacted Property Management and hi is approved for disposal in the landifll.

Print Name: Nicole Nastanși

Signature: _/s/ Nicole Nastanski

Note: "Food waste, office trash and animal carcasses do not require a radiological cle must have signed removal certification statement with Load Verification." SWO USE ONLY

Load Weight (net from scale or estimate): 500
$4 / 21 / 11$ Sighature of Certifier:

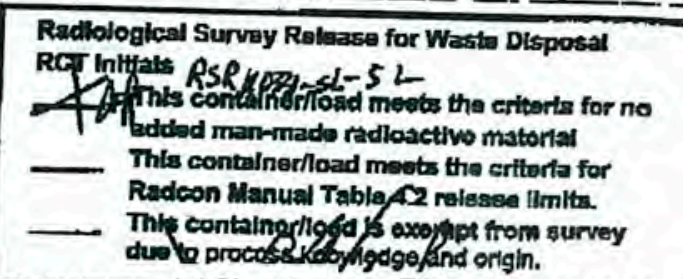

SIGNATURE: /s/ Signature on File

/s/ Signature on File 


\section{NTS On-Site HazMat Transfer - Published}

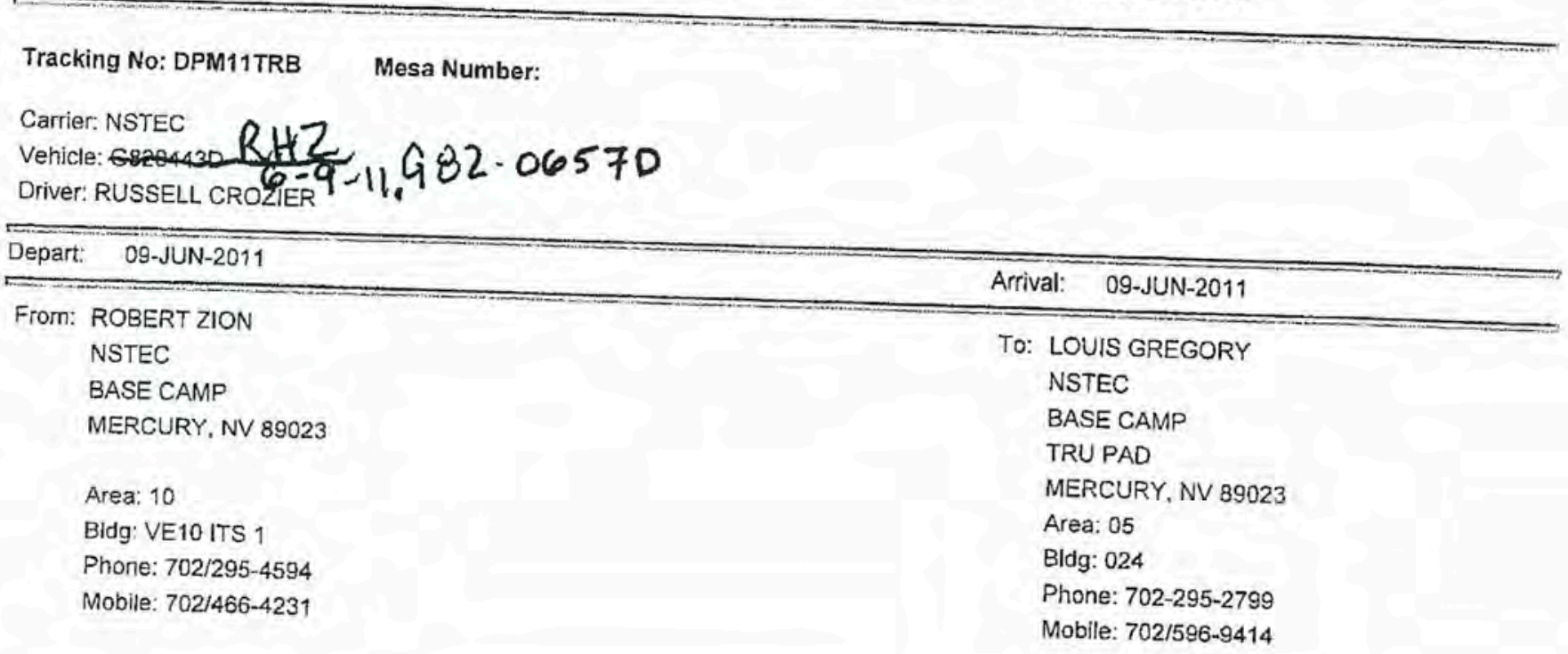

\section{Entered By: ROBERT ZION}

Modified By: ROBERT ZION

Date Entered: $\quad 07-\mathrm{JUN}-2011$

Date Modified: $\quad 08-J U N-2011$

\section{Shipped Material(s)}

RQ, UN/NA 2910, RADIOACTIVE MATERIAL, EXCEPTED PACKAGE, LIMITED QUANTITY OF
MATERIAL, 7 WASTE

(D008) RADIONUCLIDES: CS-137, SR-90, PU-238, PU-239, PU-240, PU-241, AM-241. PHYSICAL

CATEGORY EXCISIV FRM: OXIDE PACKAGE ACTIVITY: PACKAGE \# 36702A 3.35E+05 BQ

\begin{tabular}{clc} 
Package(s) Unit(s) & $\begin{array}{r}\text { Guide } \\
\text { No. }\end{array}$ \\
\hline 1 DRUM & $\begin{array}{l}45.40 \\
\text { KILOGRAM(S) } \\
\text { (GROSS) }\end{array}$ & 161 \\
&
\end{tabular}

CATEGORY: EXCLUSIVE USE SHIPMENT, FISSILE EXCEPTED, ON-SITE TRANSFER.

\section{Emergency Response Number 702-295-0311}

\footnotetext{
Secondary Emergency Response Contact And/Or Comments

STEFAN DUKE (702) 630-0423. ON COMPOUND TRANSFER. TO BE SHIPPED OFFSITE AT A LATER TIME FOR TREATMENT.
}

In the event of an emergency on the Nevada Test Site, immediately contact the Operations Coordination Center (OCC) Duty Manager at
$702 / 295-0311$ for assistance.

\section{EMERGENCY RESPONSE}

\section{By Phone}

702-295-0311

By Radio

'MAYDAY - MAYDAY - MAYDAY'
In the event of an incident involving Hazardous Material:

1. Gather HazMat shipping papers and NAER Guidebook

2. Isolate the immediate area

3. Assess the situation:

a. Fire, Spill, or Leak?

b. People, Property, or the Environment at risk?

4. Contact On-site Emergency Response Personnel

5. Reference On-Site HazMat Transfer Tracking Number This is to certify that the above-named materials are properly classified, described, packaged, marked, placarded, and labeled and are in proper been trained and tested to tbe geayirements of 49 FFR. Part 172-700 and is cepartment of Transportation. As a signatory I cerfify that I have Authorized signature, /s/ Robert Zion Received by: /s/ Signature on File

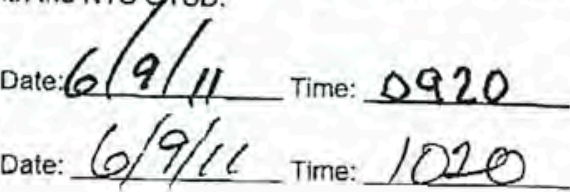




\section{NTS On-Site HazMat Transfer - Published}

Tracking No: ITL11005

Mesa Number:

Carrier: NSTEC

Vehicle: G820657D

Driver: RUSSELL CROZIER

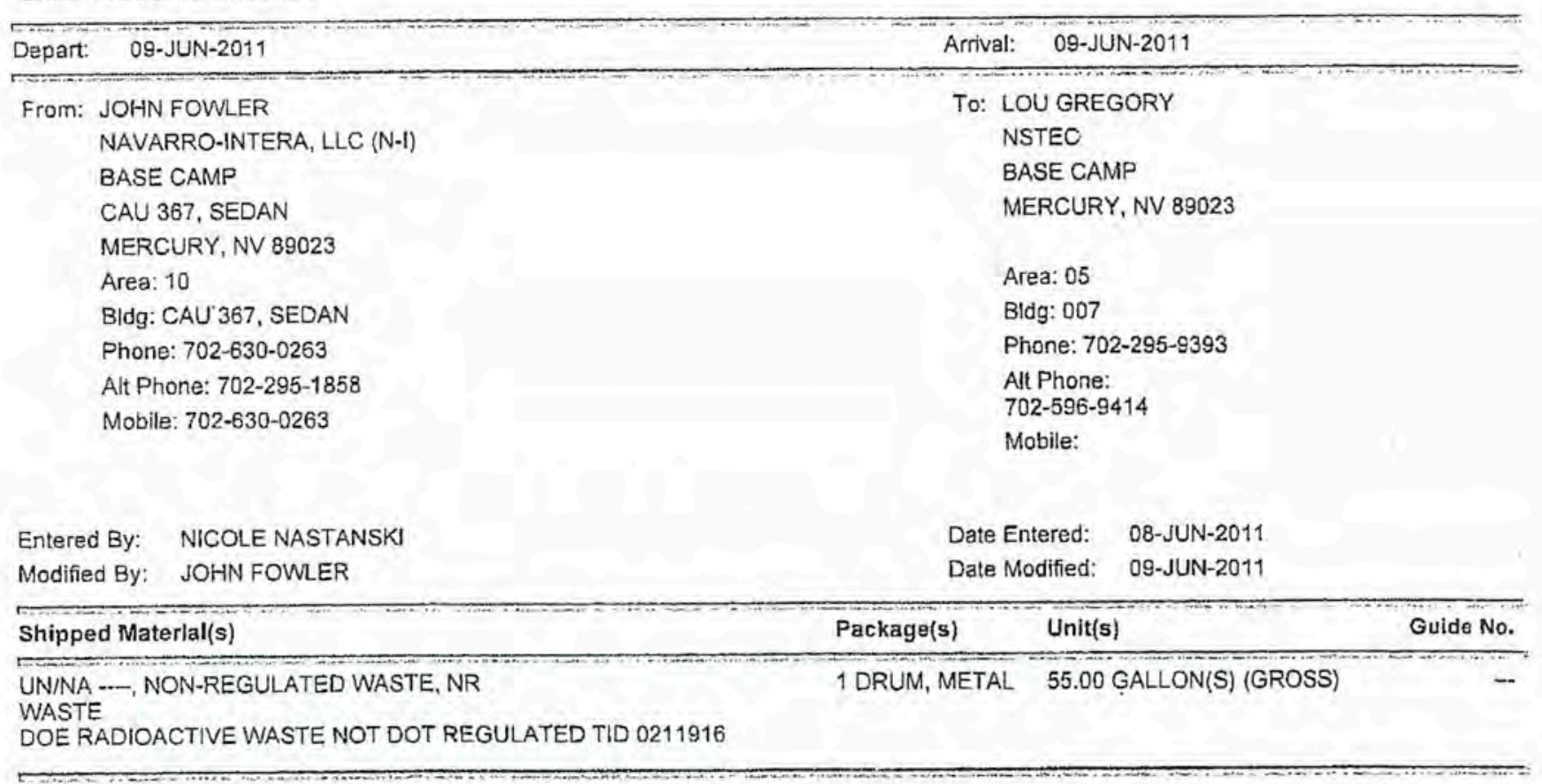

\section{Emergency Response Number 702-295-0311}

Secondary Emergency Response Contact And/Or Comments JOHN FOWLER 702-630-0263

In the event of an emergency on the Nevada Test Site, Immediately contact the Operations Coordination Center (OCC) Duty Manager at 702/295-0311 for assistance.

EMERGENCY RESPONSE

$\begin{array}{ll}\text { By Phone } & \text { In the event of an incident involving Hazardous Material: } \\ 702-295-0311 & \begin{array}{ll}\text { 1. Gather HazMat shipping papers and NAER Guidebook } \\ \text { By Radio } & \text { 2. Isolate the immediate area } \\ \text { 3. Assess the situation: } & \text { a. Fire, Splil, or Leak? } \\ \text { 'MAYDAY - MAYDAY - MAYDAY' } & \text { b. People, Property, or the Environment at risk? } \\ & \text { 4. Contact On-site Emergency Response Personnel } \\ & \text { 5. Reference On-Site HazMat Transfer Tracking Number }\end{array}\end{array}$

This is to certify that the above-named materials are properly classified, described, packaged, marked, placarded, and labeled and are in proper condition for transportation according to the applicable regulations of the U.S Department of Transportation. As a slgnatory I cerfify that I have been trained and tested to the requirements of 49 CFR, Part 172-700 and is compliant with the NTS OTSD.

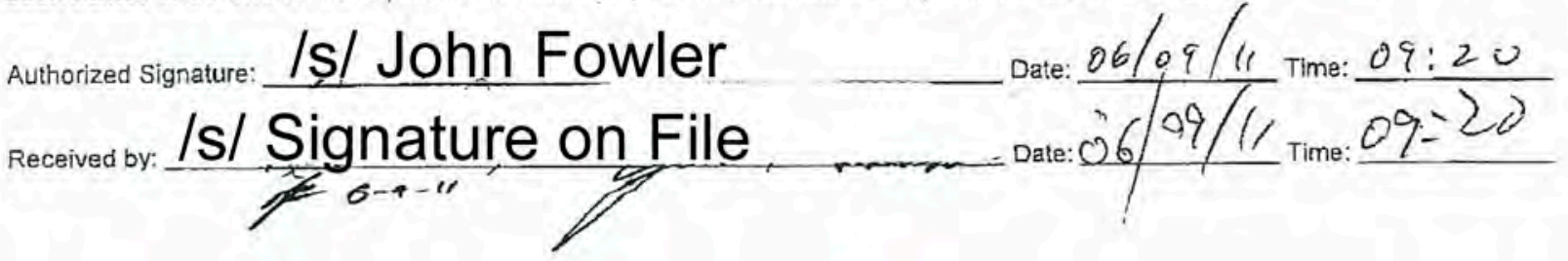




\section{Certificate of Disposal}

This is to certify that the Waste Stream No. LITN000000006, Revision 14, shipment number ITL11005, with container number $36701 \mathrm{~A}$ was shipped and received at the Nevada National Security Site Radioactive Waste Management Complex in Area 5 for disposal as stated below.

John M. Fowlo Shipped by

)

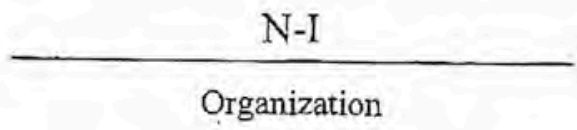

Organization

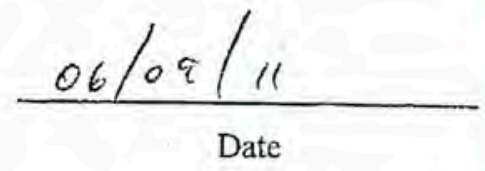

Title

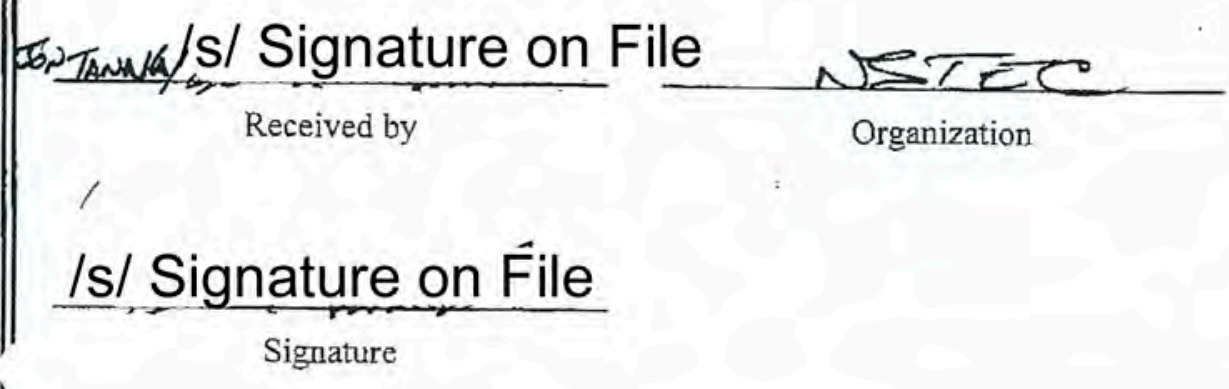

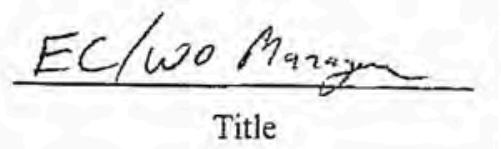

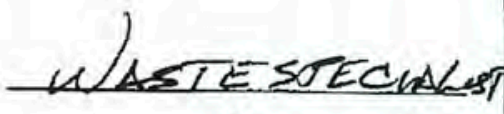

Title

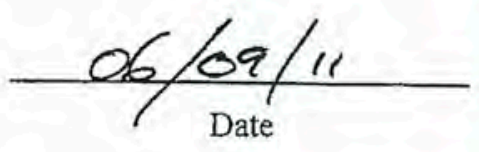




\section{Attachment D-2}

\section{Use Restrictions}

(12 Pages) 
CAU Number/Description: CAU 367, Area 10 Sedan, Ess and Uncle Unit Craters

Applicable CAS Number/Description: CAS 10-45-01, U-10h Crater (Sedan)

Contact (Federal Sub-Project Director/Sub-Project): $\underline{\text { NSA/NSO Soils Sub-Project Director }}$

Physical Description:

Surveyed Area (UTM, Zone 11, NAD 27, meters):

\begin{tabular}{ll} 
Easting & Northing \\
\hline $585,063.3$ & $4,114,360.1$ \\
$584,689.8$ & $4,114,188.7$ \\
$584,405.4$ & $4,114,376.9$ \\
$584,256.7$ & $4,114,643.3$ \\
$584,355.0$ & $4,114,865.2$ \\
$584,485.4$ & $4,114,833.6$ \\
$584,510.5$ & $4,114,814.8$ \\
$584,558.6$ & $4,114,794.1$ \\
$584,568.7$ & $4,114,802.0$ \\
$584,528.9$ & $4,114,824.5$ \\
$584,533.8$ & $4,114,850.7$ \\
$584,460.9$ & $4,114,886.9$ \\
$584,436.5$ & $4,114,929.6$ \\
$584,407.5$ & $4,114,974.6$ \\
$584,455.2$ & $4,115,084.4$ \\
$584,639.0$ & $4,115,222.5$ \\
$584,956.0$ & $4,115,228.5$ \\
$585,164.2$ & $4,114,865.4$ \\
$585,165.0$ & $4,114,510.9$
\end{tabular}

Depth: No depth limitations

Survey Method (GPS, etc): GPS and Heads up digitizing

Basis for UR:

Summary Statement: This use restriction is to protect site workers from inadvertent exposure. Subsurface contamination is assumed to be present within the crater area from the direct injection of radionuclides into the soil from the Sedan nuclear test. This contamination, if exposed through excavation, could cause a site worker to receive a dose exceeding 25 mrem/yr. The analytical results and locations of all samples collected are presented in the CADD/CR for CAU 367. Personnel are restricted from performing work in this area that would require personnel to be present for other than short term activities conducted under the current use. Current land usage is defined as site visits, maintenance of the fence, radiological surveys, short duration radiological training, and retrieval of objects within the use-restricted area. Any activities to be conducted within this area that are not consistent with these defined short term activities require the prior notification and approval of the NDEP.

\section{Contaminants Table:}




\begin{tabular}{|c|c|c|c|}
\hline \multicolumn{5}{|c|}{ Maximum Concentration of Contaminants at CAU 367 } \\
Remote Work Area Exposure Scenario
\end{tabular}

Site Controls: The use restriction encompasses the area where surface soil contamination exceeds the FAL of 25 mrem in 336 hours (the Remote Work Area annual exposure scenario). The UR is established at the boundary identified by the coordinates listed above and depicted in the attached figure. Site controls include warning signs placed around the userestricted area.

UR Maintenance Requirements:

Description: The UR is recorded in the FFACO database, NNSA/NSO Facility Management System, and the NNSA/NSO CAU/CAS files.

Inspection/Maintenance Frequency: Annual post-closure inspections will be conducted to ensure postings are in place, intact, and legible.

The future use of any land related to this Corrective Action Unit (CAU), as described by the above surveyed location, is restricted from any DOE or Air Force activity that may alter or modify the containment control as approved by the state and identified in the CAU CR or other CAU documentation unless appropriate concurrence is obtained in advance.

Comments: None.

Submitted By: ./s/ Kevin Cabble

Date:

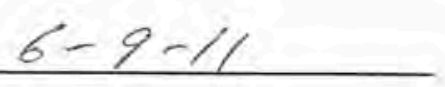


CAU Number/Description: CAU 367, Area 10 Sedan, Ess and Uncle Unit Craters Applicable CAS Number/Description: CAS 10-45-02, Ess Crater Site

Contact (Federal Sub-Project Director/Sub-Project): $\underline{\text { NSA/NSO Soils Sub-Project Director }}$

Physical Description:

Surveyed Area (UTM, Zone 11, NAD 27, meters):

Easting Northing

$584,936.9 \quad 4,113,658.2$

$584,808.7 \quad 4,113,725.3$

$584,786.7 \quad 4,113,868.1$

$584,939.7 \quad 4,113,864.9$

$584,996.4 \quad 4,113,742.8$

Depth: No depth limitations

Survey Method (GPS, etc): $\underline{\text { GPS }}$

Basis for UR:

Summary Statement:This use restriction is to protect site workers from inadvertent exposure. Subsurface contamination is assumed to be present within the crater area from the direct injection of radionuclides into the soil from the Ess nuclear test. This contamination, if exposed through excavation, could cause a site worker to receive a dose exceeding 25 mrem/yr. The analytical results and locations of all samples collected are presented in the CADD/CR for CAU 367. Personnel are restricted from performing work in this area that would require personnel to be present for other than short term activities conducted under the current use. Current land usage is defined as site visits, maintenance of the fence, radiological surveys, short duration radiological training, and retrieval of objects within the use-restricted area. Any activities to be conducted within this area that are not consistent with these defined short term activities require the prior notification and approval of the NDEP.

\section{Contaminants Table:}

\begin{tabular}{|c|c|c|c||}
\hline \multicolumn{5}{|c|}{ Maximum Concentration of Contaminants at CAU 367 } \\
Remote Work Area Exposure Scenario
\end{tabular}

Site Controls: The use restriction encompasses the area where surface soil contamination exceeds the FAL of $25 \mathrm{mrem}$ in 336 hours (the Remote Work Area annual exposure scenario). The UR is established at the boundary identified by the coordinates listed above and depicted in the attached figure. Site controls include warning signs placed around the userestricted area.

UR Maintenance Requirements:

Description: The UR is recorded in the FFACO database, NNSA/NSO Facility Management System, and the NNSA/NSO CAU/CAS files.

Inspection/Maintenance Frequency: Annual post-closure inspections will be conducted to ensure postings are 
The future use of any land related to this Corrective Action Unit (CAU), as described by the above surveyed location, is restricted from any DOE or Air Force activity that may alter or modify the containment control as approved by the state and identified in the CAU CR or other $\mathrm{CAU}$ documentation unless appropriate concurrence is obtained in advance.

Comments: None.

Submitted By:

./s/ Kevin Cabble

Date:

$6-9-11$ 


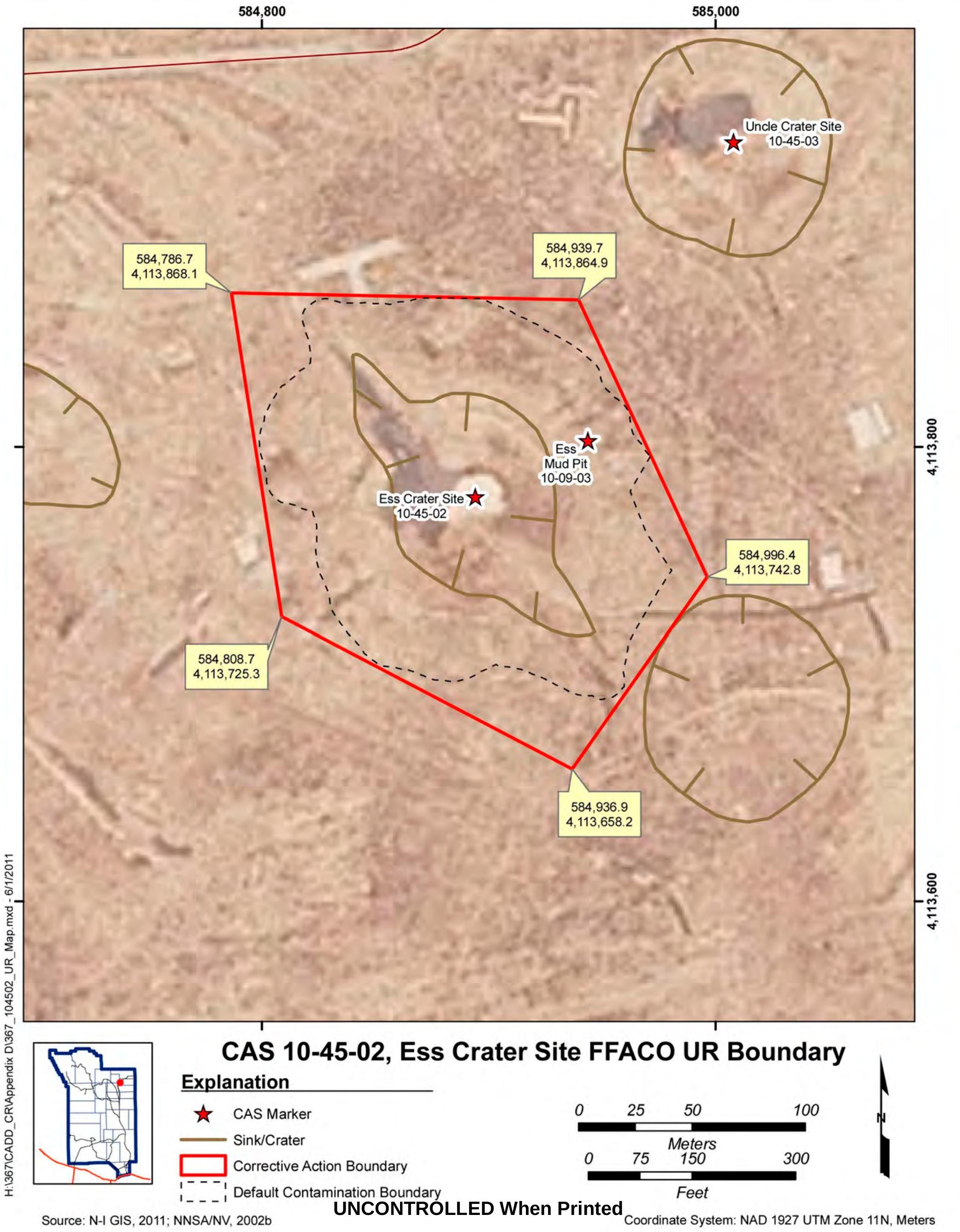


CAU Number/Description: CAU 367, Area 10 Sedan, Ess and Uncle Unit Craters

Applicable CAS Number/Description: CAS 10-45-03, Uncle Crater Site

Contact (Federal Sub-Project Director/Sub-Project): $\underline{\text { NSA/NSO Soils Sub-Project Director }}$

Physical Description:

Surveyed Area (UTM, Zone 11, NAD 27, meters):

\begin{tabular}{cc} 
Easting & Northing \\
\hline $585,077.6$ & $4,113,901.0$ \\
$584,999.7$ & $4,113,851.2$ \\
$584,928.8$ & $4,113,918.3$ \\
$584,983.0$ & $4,114,002.9$ \\
$585,058.4$ & $4,113,982.6$
\end{tabular}

Depth: No depth limitations

Survey Method (GPS, etc): $\underline{\text { GPS }}$

Basis for UR:

Summary Statement: This use restriction is to protect site workers from inadvertent exposure. Subsurface contamination is assumed to be present within the crater area from the direct injection of radionuclides into the soil from the Uncle nuclear test. This contamination, if exposed through excavation, could cause a site worker to receive a dose exceeding 25 mrem/yr. The analytical results and locations of all samples collected are presented in the CADD/CR for CAU 367. Personnel are restricted from performing work in this area that would require personnel to be present for other than short term activities conducted under the current use. Current land usage is defined as site visits, maintenance of the fence, radiological surveys, short duration radiological training, and retrieval of objects within the use-restricted area. Any activities to be conducted within this area that are not consistent with these defined short term activities require the prior notification and approval of the NDEP.

\section{Contaminants Table:}

\begin{tabular}{|c|c|c|c|}
\hline \multicolumn{4}{|c|}{$\begin{array}{c}\text { Maximum Concentration of Contaminants at CAU } 367 \\
\text { Remote Work Area Exposure Scenario }\end{array}$} \\
\hline Constituent & $\begin{array}{c}\text { Maximum } \\
\text { Concentration }\end{array}$ & Action Level & Units \\
\hline TED & 14.3 & 25 & mrem/336 hours \\
\hline
\end{tabular}

Site Controls: The use restriction encompasses the area where surface soil contamination exceeds the FAL of $25 \mathrm{mrem}$ in 336 hours (the Remote Work Area annual exposure scenario). The UR is established at the boundary identified by the coordinates listed above and depicted in the attached figure. Site controls include warning signs placed around the userestricted area.

\section{UR Maintenance Requirements:}

Description: The UR is recorded in the FFACO database, NNSA/NSO Facility Management System, and the NNSA/NSO CAU/CAS files.

Inspection/Maintenance Frequency: Annual post-closure inspections will be conducted to ensure postings are 
The future use of any land related to this Corrective Action Unit (CAU), as described by the above surveyed location, is restricted from any DOE or Air Force activity that may alter or modify the containment control as approved by the state and identified in the CAU CR or other CAU documentation unless appropriate concurrence is obtained in advance.

Comments: None.

Submitted By:

./s/ Kevin Cabble

Date:

$6-9-11$ 


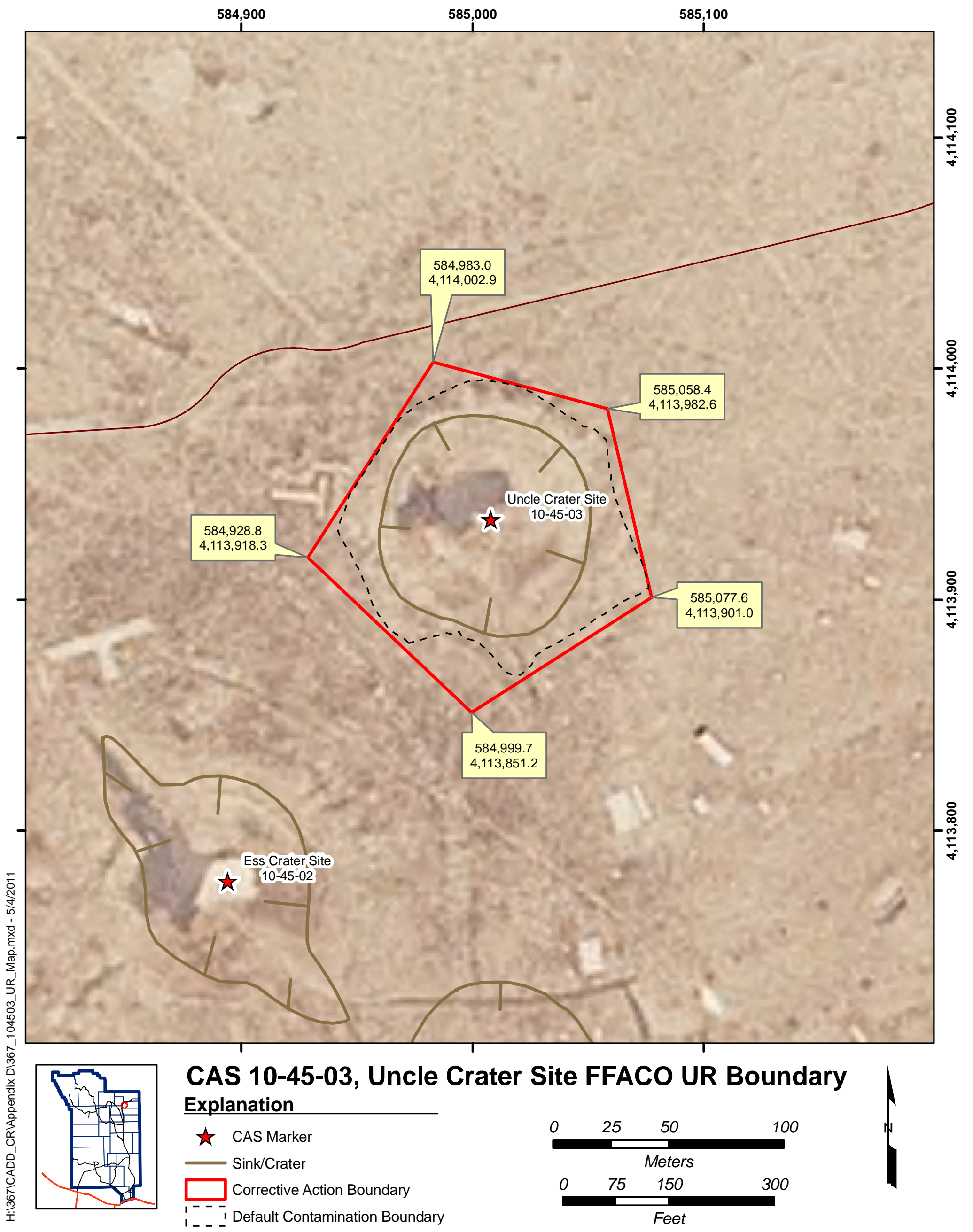


CAU Number/Description: CAU 367, Area 10 Sedan, Ess and Uncle Unit Craters

Applicable CAS Number/Description: CAS 10-45-01, U-10h Crater (Sedan); CAS 10-45-02, Ess Crater Site; CAS 1045-03, Uncle Crater Site

Contact (Federal Sub-Project Director/Sub-Project): NNSA/NSO Soils Sub-Project Director

Physical Description:

Surveyed Area (UTM, Zone 11, NAD 27, meters):

Administrative Use Restriction Coordinates:

\begin{tabular}{ll} 
Easting & Northing \\
\cline { 2 - 2 } $585,073.5$ & $4,113,360.4$ \\
$584,502.8$ & $4,113,572.4$ \\
$584,084.2$ & $4,113,822.4$ \\
$583,991.5$ & $4,114,549.6$ \\
$583,654.3$ & $4,114,986.9$ \\
$583,938.4$ & $4,115,378.5$ \\
$584,359.4$ & $4,115,142.0$ \\
$585,031.1$ & $4,115,376.8$ \\
$586,195.5$ & $4,114,723.6$ \\
$586,133.5$ & $4,113,860.4$
\end{tabular}

Depth: To $5 \mathrm{~cm}$ below native soil surface

Survey Method (GPS, etc): $\underline{\text { Heads up digitizing }}$

Basis for UR:

Summary Statement: This administrative use restriction is to protect site workers from inadvertent exposure. Data from surface sampling indicates that an industrial worker could potentially received a 25 mrem dose if exposed to the location with the maximum detected radioactivity for an extended time (i.e., more than the current land use at this site). The current land use at this site includes site visits, maintenance of the fence, radiological surveys, short duration radiological training, and retrieval of objects within the use-restricted area. As a best management practice, this administrative use restriction will restrict personnel from performing work in this location that would result in a more intensive use of the area than current land use. Any activities to be conducted within this area that are not consistent with this defined current land use require prior notification and approval of the NDEP. The analytical results and locations of all samples collected are presented in the CADD/CR for CAU 367. Conditions that may warrant reevaluation include a change in the land use or the reduction in dose due to natural radioactive decay. It is estimated that the dose at CAU 367 will be less than $25 \mathrm{mrem} / \mathrm{yr}$ in approximately 69.6 years.

Contaminants Table:

\begin{tabular}{|c|c|c|c|}
\hline \multicolumn{4}{|c|}{$\begin{array}{l}\text { Maximum Concentration of Contaminants for CAU } 367 \\
\text { Industrial Area Exposure Scenario }\end{array}$} \\
\hline Constituent & $\begin{array}{c}\text { Maximum } \\
\text { Concentration }\end{array}$ & Action Level & Units \\
\hline TED & 95.5 & 25 & mrem/2250 hours \\
\hline
\end{tabular}

Site Controls: This administrative use restriction area is established at the boundary identified by the coordinates listed 
above and depicted in the attached figure, excluding the three CAS-specific FFACO UR boundaries at CAU 367 . No site controls are required for this administrative UR other than the administrative controls for land use at the NNSS.

UR Maintenance Requirements:

Description: The UR is recorded in the FFACO database, NNSA/NSO Facility Management System, and the NNSA/NSO CAU/CAS files.

Inspection/Maintenance Frequency: N/A

The future use of any land related to this Corrective Action Unit (CAU), as described by the above surveyed location, is restricted from any DOE or Air Force activity that may alter or modify the containment control as approved by the state and identified in the CAU CR or other CAU documentation unless appropriate concurrence is obtained in advance.

Comments: None.

Submitted By: ../s/, Kevin Cabble

Date:

$6-9-11$ 


\section{Appendix E}

\section{Evaluation of Corrective Action Alternatives}




\section{E.1.0 Introduction}

This appendix presents the corrective action objectives for CAU 367, describes the general standards and decision factors used to screen the various CAAs, and develops and evaluates a set of selected CAAs that will meet the corrective action objectives.

All CAAs for CAU 367 are based on the presumption that all areas within the current NNSS boundary will be controlled in perpetuity and restricted from release to the public. As such, only industrial activities are permitted, and risks to receptors under residential scenarios will not be considered for CAU 367. Should the control of the NNSS change in the future to include public access or residential use, the selected CAAs may need to be reconsidered.

\section{E.1.1 Corrective Action Objectives}

On May 1, 1996, EPA issued an Advance Notice of Proposed Rulemaking (ANPR) for corrective action for releases from solid waste management units at hazardous waste management facilities (EPA, 1996). The EPA states that the ANPR should be considered the primary corrective action implementation guidance (Laws and Herman, 1997). The ANPR states that a basic operating principle for remedy selection is that corrective action decisions should be based on risk. It emphasizes that current and reasonably expected future land use should be considered when selecting corrective action remedies and encourages use of innovative site characterization techniques to expedite site investigations.

The ANPR provides the following EPA expectations for corrective action remedies (EPA, 1996):

- Treatment should be used to address principal threats wherever practicable and cost effective.

- Engineering controls, such as containment, should be used where wastes and contaminated media can be reliably contained, pose relatively low long-term threats, or for which treatment is impracticable.

- A combination of methods (e.g., treatment, engineering, and institutional controls) should be used, as appropriate, to protect human health and the environment.

- Institutional controls should be used primarily to supplement engineering controls as appropriate for short- or long-term management to prevent or limit exposure. 
- Innovative technologies should be considered where such technologies offer potential for comparable or superior performance or implementability, less adverse impacts, or lower costs.

- Usable groundwater should be returned to maximum beneficial use wherever practicable.

- Contaminated soils should be remediated as necessary to prevent or limit direct exposure and to prevent the transfer of unacceptable concentrations of contaminants from soils to other media.

Implementation of the corrective action will ensure that contaminants remaining at each release site will not pose an unacceptable risk to human health and the environment and that conditions at each site are in compliance with all applicable laws and regulations.

\section{E.1.2 Screening Criteria}

The screening criteria used to evaluate and select the preferred CAA are identified in the Guidance on RCRA Corrective Action Decision Documents (EPA, 1991) and the Final RCRA Corrective Action Plan (EPA, 1994).

Corrective action alternatives are evaluated based on four general corrective action standards and five remedy selection decision factors. All CAAs must meet the four general standards to be selected for evaluation using the remedy selection decision factors.

The general corrective action standards are as follows:

- Protection of human health and the environment

- Compliance with media cleanup standards

- Control the source(s) of the release

- Comply with applicable federal, state, and local standards for waste management

The remedy selection decision factors are as follows:

- Short-term reliability and effectiveness

- Reduction of toxicity, mobility, and/or volume

- Long-term reliability and effectiveness

- Feasibility

- Cost 


\section{E.1.3 Corrective Action Standards}

The following subsections describe the corrective action standards used to evaluate the CAAs.

\section{Protection of Human Health and the Environment}

Protection of human health and the environment is a general mandate of the RCRA statute (EPA, 1994). This mandate requires that the corrective action include any protective measures necessary to ensure the requirements are met. These measures may or may not be directly related to media cleanup, source control, or management of wastes.

\section{Compliance with Media Cleanup Standards}

The CAAs are evaluated for the ability to meet the proposed media cleanup standards. The media cleanup standards are the FALs.

\section{Control the Source(s) of the Release}

The CAAs are evaluated for the ability to stop further environmental degradation by controlling or eliminating additional releases that may pose a threat to human health and the environment. Unless source control measures are taken, efforts to clean up releases may be ineffective or, at best, will involve a perpetual cleanup. Therefore, each CAA must provide effective source control to ensure the long-term effectiveness and protectiveness of the corrective action.

\section{Comply with Applicable Federal, State, and Local Standards for Waste Management}

The CAAs are evaluated for the ability to be conducted in accordance with applicable federal and state regulations (hazardous waste provisions in 40 CFR 260 to 282; PCB provisions in 40 CFR 761; hazardous waste provisions in NAC 444.842 to 444.980 ).

\section{E.1.3.1 Remedy Selection Decision Factors}

The following text describes the remedy selection decision factors used to evaluate the CAAs.

\section{Short-Term Reliability and Effectiveness}

Each CAA must be evaluated with respect to its effects on human health and the environment during implementation of the selected corrective action. The following factors will be addressed for each alternative: 
- Protection of the community from potential risks associated with implementation (e.g., fugitive dusts, transportation of hazardous materials, and explosion)

- Protection of workers during implementation

- Adverse environmental impacts that may result from implementation

- The amount of time until the corrective action objectives are achieved

\section{Reduction of Toxicity, Mobility, and/or Volume}

Each CAA must be evaluated for its ability to reduce the toxicity, mobility, and/or volume of the contaminated media. Reduction in toxicity, mobility, and/or volume refers to changes in one or more characteristics of the contaminated media by using corrective measures that decrease the inherent threats associated with that media.

\section{Long-Term Reliability and Effectiveness}

Each CAA must be evaluated in terms of risk remaining at the CAU after the CAA has been implemented. The primary focus of this evaluation is on the extent and effectiveness of the control that may be required to manage the risk posed by treatment of residuals and/or untreated wastes.

\section{Feasibility}

The feasibility criterion addresses the technical and administrative feasibility of implementing a CAA and the availability of services and materials needed during implementation. Each CAA must be evaluated for the following criteria:

- Construction and Operation-The feasibility of implementing a CAA given the existing set of waste and site-specific conditions.

- Administrative Feasibility—-The administrative activities needed to implement the CAA (e.g., permits, URs, public acceptance, rights of way, offsite approval).

- Availability of Services and Materials - The availability of adequate offsite and onsite treatment, storage capacity, disposal services, necessary technical services and materials, and prospective technologies for each CAA. 


\section{Cost}

Costs for each alternative are estimated for comparison purposes only. The cost estimate for each CAA includes capital, and operation and maintenance costs, as applicable, and are provided in Section E.3.0. The following is a brief description of each component:

- Capital Costs - Costs that include direct costs that may consist of materials, labor, construction materials, equipment purchase and rental, excavation and backfilling, sampling and analysis, waste disposal, demobilization, and health and safety measures. Indirect costs are separate and not included in the estimates.

- Operation and Maintenance-Separate costs that include labor, training, sampling and analysis, maintenance materials, utilities, and health and safety measures.

\section{E.1.4 Development of Corrective Action Alternatives}

This section identifies and briefly describes the viable corrective action technologies and the CAAs considered for the primary release at CAU 367. Contamination providing a dose exceeding the FAL of $25 \mathrm{mrem} / \mathrm{RW}$-yr was not present in surface soils at the crater CASs but is assumed to be present in subsurface soils within the three craters (Sedan, Ess, and Uncle).

Based on the review of existing data, future use, and current operations at the NNSS, the following alternatives have been developed for consideration at CAU 367:

- Corrective Action Alternative 1 (CAA 1)-No Further Action

- Corrective Action Alternative 2 (CAA 2)-Clean Closure

- Corrective Action Alternative 3 (CAA 3)-Closure in Place

\section{E.1.4.1 Alternative 1-No Further Action}

Under CAA 1, no corrective action will be implemented. This alternative is a baseline case with which to compare and assess the other CAAs and their ability to meet the corrective action standards.

\section{E.1.4.2 Alternative 2-Clean Closure}

Alternative 2 includes excavating and disposing of impacted soil and debris presenting a dose exceeding the FAL of $25 \mathrm{mrem} / \mathrm{RW}$-yr to a depth of $25 \mathrm{ft}$ bgs at the three crater CASs.

The excavation area would be inside the FFACO UR boundary surrounding each of the three craters. 
At each crater CAS, the excavation would be backfilled with clean soil to the level of ground surface. This alternative also includes the removal of identified PSM and impacted soil. Following soil removal, verification soil samples would be collected and analyzed for the presence of chemical COCs (at PSM locations) and dose exceeding the FAL of 25 mrem/RW-yr (at PSM locations and the crater CASs). Contaminated materials removed would be disposed of at an appropriate disposal facility.

\section{E.1.4.3 Alternative 3-Closure in Place}

For radiological contamination, Alternative 3 includes the implementation of a UR where a radiological dose is present at levels that exceed the FAL of 25 mrem/RW-yr (i.e., inside the FFACO UR boundary at each crater). This UR would restrict inadvertent contact with contaminated media by prohibiting any activity that would cause a site worker to be exposed to a dose exceeding $25 \mathrm{mrem} / \mathrm{yr}$. Warning signs would be posted at the FFACO UR boundaries at each crater CAS to alert potential receptors. Under this alternative, debris within the FFACO UR boundary would not be removed. This alternative also includes the removal of identified PSM and impacted soil, and the collection of verification soil samples to ensure contamination was removed. Contaminated materials removed would be disposed of at an appropriate disposal facility.

\section{E.1.5 Evaluation and Comparison of Alternatives}

Each CAA presented in Section E.1.4 was evaluated based on the general corrective action standards listed in Section E.1.2. This evaluation is presented in Table E.1-1. The only CAA that did not meet the general corrective action standards was (CAA 1 the no further action alternative). This alternative was removed from further consideration.

Alternatives 2 and 3 (CAA 2 and CAA 3) met the corrective action standards and were further evaluated based on the remedy selection decision factors described in Section E.1.2. This evaluation is presented in Table E.1-2. For each remedy selection decision factor, the CAAs were ranked relative to one another. The CAA with the least desirable impact on the remedy selection decision factor was given a ranking of 1 . The CAAs with increasingly desirable impacts on the remedy selection decision factor received increasing rank numbers. The CAAs that would have an equal 
Table E.1-1

Evaluation of General Corrective Action Standards

\begin{tabular}{|c|c|c|}
\hline \multicolumn{3}{|c|}{$\begin{array}{c}\text { CAS 10-45-01, U-10h Crater (Sedan); } \\
\text { CAS 10-45-02, Ess Crater Site; and CAS 10-45-03, Uncle Crater Site }\end{array}$} \\
\hline \multicolumn{3}{|c|}{ CAA 1, No Further Action } \\
\hline Standard & Comply? & Explanation \\
\hline Protection of Human Health and the Environment & No & $\begin{array}{l}\text { Subsurface contamination is present that could } \\
\text { provide an excavation worker a dose exceeding the } \\
\text { FAL of } 25 \text { mrem/RW-yr. }\end{array}$ \\
\hline Compliance with Media Cleanup Standards & No & $\begin{array}{l}\text { Subsurface contamination is present that could } \\
\text { provide an excavation worker a dose exceeding the } \\
\text { FAL of } 25 \text { mrem/RW-yr. }\end{array}$ \\
\hline Control of the Source(s) of the Release & Yes & $\begin{array}{l}\text { Only subsurface contamination is present exceeding } \\
\text { the FAL of } 25 \text { mrem/RW-yr and is not subject to } \\
\text { significant migration. }\end{array}$ \\
\hline $\begin{array}{l}\text { Compliance with Applicable Federal, State, and } \\
\text { Local Standards for Waste Management }\end{array}$ & Yes & This alternative would not generate waste. \\
\hline \multicolumn{3}{|c|}{ CAA 2, Clean Closure } \\
\hline Standard & Comply? & Explanation \\
\hline Protection of Human Health and the Environment & Yes & $\begin{array}{l}\text { Contamination exceeding the risk-based action levels } \\
\text { would be removed. }\end{array}$ \\
\hline Compliance with Media Cleanup Standards & Yes & $\begin{array}{l}\text { Contamination exceeding the risk-based action levels } \\
\text { would be removed. }\end{array}$ \\
\hline Control of the Source(s) of the Release & Yes & $\begin{array}{l}\text { Contamination exceeding the risk-based action levels } \\
\text { would be removed. }\end{array}$ \\
\hline $\begin{array}{l}\text { Compliance with Applicable Federal, State, and } \\
\text { Local Standards for Waste Management }\end{array}$ & Yes & $\begin{array}{l}\text { Excavated waste would be managed in compliance } \\
\text { with all standards. }\end{array}$ \\
\hline \multicolumn{3}{|c|}{ CAA 3, Closure in Place with Administrative Controls } \\
\hline Standard & Comply? & Explanation \\
\hline Protection of Human Health and the Environment & Yes & $\begin{array}{l}\text { A UR would be implemented to protect excavation } \\
\text { workers from inadvertant exposure. }\end{array}$ \\
\hline Compliance with Media Cleanup Standards & Yes & $\begin{array}{l}\text { Although COCs would not be removed, the CASs } \\
\text { would be controlled to prevent workers from receiving } \\
\text { a dose exceeding the FAL of } 25 \text { mrem/RW-yr. }\end{array}$ \\
\hline Control of the Source(s) of the Release & Yes & $\begin{array}{l}\text { Only subsurface contamination is present exceeding } \\
\text { the FAL of } 25 \text { mrem/RW-yr and is not subject to } \\
\text { significant migration. }\end{array}$ \\
\hline $\begin{array}{l}\text { Compliance with Applicable Federal, State, and } \\
\text { Local Standards for Waste Management }\end{array}$ & Yes & This alternative would not generate waste. \\
\hline
\end{tabular}


Table E.1-2

Evaluation of Remedy Selection Decision Factors

\begin{tabular}{|c|c|c|}
\hline \multicolumn{3}{|c|}{$\begin{array}{c}\text { CAS 10-45-01, U-10h Crater (Sedan); } \\
\text { CAS 10-45-02, Ess Crater Site; and CAS 10-45-03, Uncle Crater Site }\end{array}$} \\
\hline \multicolumn{3}{|c|}{ CAA 1, No Further Action } \\
\hline Standard & Rank & Explanation \\
\hline \multicolumn{3}{|c|}{ Not evaluated, as this CAA did not meet the General Corrective Action Standards } \\
\hline \multicolumn{3}{|c|}{ CAA 2, Clean Closure } \\
\hline Standard & Rank & Explanation \\
\hline Short-Term Reliability and Effectiveness & 1 & $\begin{array}{l}\text { This alternative is reliable and effective in protecting } \\
\text { human health by eliminating COCs, but involves extensive } \\
\text { short-term worker exposure to COCs and worker safety risk } \\
\text { during soil removal operations. Additional short-term risks to } \\
\text { site workers include exposure during the transportation and } \\
\text { disposal of excavated soil and debris. }\end{array}$ \\
\hline Reduction of Toxicity, Mobility, and/or Volume & 2 & $\begin{array}{l}\text { This alternative would reduce contaminant toxicity, mobility, } \\
\text { and volume. }\end{array}$ \\
\hline Long-Term Reliability and Effectiveness & 2 & $\begin{array}{l}\text { This alternative is reliable and effective in the long term } \\
\text { because removal of the contaminated media would eliminate } \\
\text { future exposure of site workers to cOCs. }\end{array}$ \\
\hline Feasibility & 1 & $\begin{array}{l}\text { This alternative is feasible. Although substantial resources } \\
\text { are required in the short term, no resources are required in the } \\
\text { long term. }\end{array}$ \\
\hline Cost & 1 & $\begin{array}{l}\text { The cost to remove and dispose of contaminated soil at the } \\
\text { three crater CASs is estimated to exceed } \$ 3 \text { billion. }\end{array}$ \\
\hline Score & 7 & \\
\hline \multicolumn{3}{|c|}{ CAA 3, Closure in Place with Administrative Controls } \\
\hline Standard & Rank & Explanation \\
\hline Short-Term Reliability and Effectiveness & 2 & $\begin{array}{l}\text { This alternative is reliable and effective in protecting human } \\
\text { health by preventing contact with COCs. It involves minimal } \\
\text { short-term worker exposure during installation of UR postings. }\end{array}$ \\
\hline Reduction of Toxicity, Mobility, and/or Volume & 1 & $\begin{array}{l}\text { This alternative would not reduce contaminant toxicity, mobility, } \\
\text { or volume. }\end{array}$ \\
\hline Long-Term Reliability and Effectiveness & 1 & $\begin{array}{l}\text { This alternative is reliable in the long term with ongoing } \\
\text { maintenance. It is effective in providing protection of human } \\
\text { health by preventing inadvertent contact with COCs. }\end{array}$ \\
\hline Feasibility & 2 & $\begin{array}{l}\text { This alternative is easily implemented, with minimal resources } \\
\text { required in the short and long terms. }\end{array}$ \\
\hline Cost & 2 & $\begin{array}{l}\text { Installation costs are estimated at } \$ 30,000 \text { for the first year. } \\
\text { Ongoing maintenance costs for this alternative are estimated at } \\
\$ 3,000 \text { annually. The total cost for this alternative over a } \\
100 \text {-year monitoring period is } \$ 327,000 \text {. }\end{array}$ \\
\hline Score & 8 & \\
\hline
\end{tabular}


impact on the remedy selection decision factor received an equal ranking number. The scoring listed in this table represents the sum of the remedy selection decision factor rankings for each CAA.

The five EPA remedy selection decision factors are (1) short-term reliability and effectiveness; (2) reduction of toxicity, mobility, and/or volume; (3) long-term reliability and effectiveness; (4) feasibility; and (5) cost. These factors are provided in Table E.1-2.

The first remedy selection decision factor-short-term reliability and effectiveness — is a qualitative measure of the impacts on human health and the environment during implementation of the CAA. While clean closure is both reliable and effective in the long term, this alternative involves increased, short-term exposure of site workers to radiological contamination during soil and debris removal. In contrast, closure in place does not require removal of soil, there is minimal short-term exposure of site workers as they post UR signs, and disturbance of contaminated soil and debris is not necessary.

The second remedy selection decision factor-reduction of toxicity, mobility, and/or volume-is a qualitative measure of changes in characteristics of contaminated media that result from implementation of the CAA. Under clean closure, contaminated media that exceeds FALs (to a depth of $7.5 \mathrm{~m}$ ) would be removed from the area, thereby reducing the mobility and the volume of contaminated media. Closure in place does not reduce the toxicity, mobility, or volume of contaminants.

The third remedy selection decision factor-long-term reliability and effectiveness — is a qualitative evaluation of performance following site closure and into the future. Removal of contaminated media as a result of clean closure provides long-term reliability and effectiveness through the removal of contaminated media, thus eliminating future exposure to contaminants. Closure in place also provides long-term reliability and effectiveness, but is contingent on the maintenance and effectiveness of URs in preventing inadvertent exposure.

The fourth remedy selection decision factor-feasibility —includes an evaluation of the requirements for construction and operation as well as administrative constraints. For the clean closure alternative, substantial construction, operation, and administrative actions consistent with soil removal and management of generated wastes are needed. For the closure in place alternative, no construction is 
required other than the installation of postings; however, regular maintenance and administrative requirements would be ongoing.

The fifth remedy selection decision factor — cost—includes assessment of both capital (direct) costs of implementation and costs for operation and maintenance of the corrective action. As shown in Table E.1-2, the estimated cost for clean closure at the three crater CASs would exceed $\$ 3$ billion. The cost for closure in place was estimated at $\$ 327,000$, given a 100 -year term monitoring period. 


\section{E.2.0 Recommended Alternative}

Three CAAs were evaluated for the three crater CASs in CAU 367: no further action (CAA 1), clean closure (CAA 2), and closure in place (CAA 3). Only CAA 2 and CAA 3 met the general corrective action standards of protection of human health and the environment, compliance with media cleanup and waste management standards, and control of the source of release. Further examination of the two CAAs using the five EPA remedy selection decision factors resulted in an overall score of 7 (less desirable) for CAA 2 and an overall score of 8 (more desirable) for CAA 3. Although the scores are based primarily on the evaluation of the two CAAs by the five remedy selection decision factors, additional information was factored into the evaluation of the alternatives:

- Existing NNSS administrative controls (e.g., access restrictions and control of site activities)

- Remoteness of the sites

- Lack of nearby structures and regular work activities

- Current and planned use of the sites

- Disposal of excavated soil and debris in an existing permitted disposal crater at NNSS (i.e., contamination would simply be moved from one area to another with no added controls)

- Present-day stability of the contaminated soil as evidenced by a mature plant community

- Continual deposition of soil over contamination in craters through erosion and wind

- Development of soil surface durability (i.e., soil crust)

Based on the evaluation, closure in place (CAA 3) is the preferred alternative for the three crater CASs. Selection of this CAA is consistent with past practices for CASs that contain COCs and where there would be significant costs and short-term health risks to workers involved in cleanup activities. However, if, the control of the NNSS should change in the future to include public access or residential use, the selected CAA may need to be reconsidered. 


\section{E.3.0 Cost Estimates and Assumptions}

The cost for clean closure (CAA 2) is estimated to exceed \$3 billion to conduct the IRCORZ IQ Tactivities:

- Conduct preparation and procurement activities

- Grub surface and collect debris

- Excavate, load, and dispose of contaminated soil at the three crater CASs

- Backfill excavation with clean soil

- Dispose of debris

- Decontaminate equipment

The estimated costs for clean closure of CAU 367 was based on removing contaminated soil within the $25 \mathrm{mrem} / \mathrm{RW}$-yr boundary to a depth of $7.5 \mathrm{~m}(25 \mathrm{ft})$. The area within this boundary at each crater CAS is presented below in Table E.3-1.

Table E.3-1

Use Restriction Boundary Areas at CAU 367

\begin{tabular}{|c|c|c|}
\hline CAS Number & CAS Description & Area $\mathbf{( m}^{\mathbf{2}} \mathbf{~}$ \\
\hline \hline $10-45-01$ & Sedan crater & 680,000 \\
\hline $10-45-02$ & Ess crater & 30,000 \\
\hline $10-45-03$ & Uncle crater & 15,000 \\
\hline
\end{tabular}

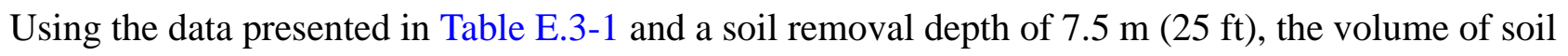
excavated would be approximately 5.1 million cubic meters at the Sedan crater, 227,000 cubic meters at the Ess crater, and 106,000 cubic meters at the Uncle crater, amounting to a total of 5.43 million cubic meters. These figures, which have been rounded, represent a rough estimate of the total volume of soil that would require removal based on the FAL of $25 \mathrm{mrem} / \mathrm{RW}-\mathrm{yr}$. At an estimated cost of \$579 per cubic meter of soil excavated, the total cost for CAA 2 (clean closure) at CAU 367 would exceed \$3 billion.

The costs for closure in place (CAA 3) are limited to those derived from acquiring, hanging, inspecting, and occasionally replacing UR signs, and are estimated to be approximately \$30,000 for the first year and \$3,000 for each year thereafter. Based on a potential long-term monitoring period of 100 years, the total cost for CAA 3 is $\$ 327,000$. 


\section{E.4.0 References}

EPA, see U.S. Environmental Protection Agency.

Laws, E.P., and S.A. Herman, U.S. Environmental Protection Agency. 1997. Memorandum to RCRA/CERCLA Senior Policy Managers Region I-X titled "Use of the Corrective Action Advance Notice of Proposed Rulemaking as Guidance,” 17 January. Washington, DC: Offices of Solid Waste and Emergency Response, and Enforcement and Compliance Assurance.

U.S. Environmental Protection Agency. 1991. Guidance on RCRA Corrective Action Decision Documents: The Statement of Bases, Final Decision and Response to Comments, EPA/540/G-91/011. Washington, DC: Office of Waste Programs Enforcement.

U.S. Environmental Protection Agency. 1994. Final RCRA Corrective Action Plan, EPA/520-R-94-004. Washington, DC: Office of Solid Waste and Emergency Response.

U.S. Environmental Protection Agency. 1996. “Corrective Action for Releases from Solid Waste Management Units at Hazardous Waste Management Facilities,” 1 May. In Federal Register, Vol. 61, No. 85. 


\section{Appendix F}

\section{Composite Sample Plot Analytical Data}




\section{F.1.0 Primary Release Sample Data}

\section{F.1.1 Soil Analytical Data}

Analytical results for radionuclides in environmental samples collected at CAU 367 sample plots that were detected above MDCs are presented in Tables F.1-1 through F.1-8. Although these individual radionuclide results were not considered in making decisions related to the primary release, they are presented here for completeness. The data are presented by sample vector (northeast, east, south, and northwest) and analytical method (i.e., gamma spectroscopy and isotopic analyses).

- $\quad$ Northeast Vector (sample plots A, B, C, D)

- $\quad$ East Vector (sample plots E, F, G, H)

- $\quad$ South Vector (sample plots J, K, L, M)

- $\quad$ Northwest Vector (sample plots N, P, Q, R)

\section{F.1.2 Thermoluminescent Dosimeter Element Data}

Results for the TLDs staged at CAU 367 are presented in Tables F.1-9 and F.1-10. These data are the direct radiation measurements from each of the three TLD elements used in the evaluation of the primary release (i.e., the data have not been corrected for background). Table F.1-9 presents the TLD element data for the environmental TLDs staged at CAU 367. Table F.1-10 presents the TLD element data for the field background TLDs (a detailed discussion of background TLDs is provided in Section A.2.2.6). 
Table F.1-1

Gamma Spectroscopy Sample Results for Radionuclides Detected above MDCs at Northeast Vector

\begin{tabular}{|c|c|c|c|c|c|c|c|}
\hline \multirow{2}{*}{$\begin{array}{l}\text { Sample } \\
\text { Plot }\end{array}$} & \multirow{2}{*}{$\begin{array}{l}\text { Sample } \\
\text { Number }\end{array}$} & \multirow{2}{*}{$\begin{array}{c}\text { Depth } \\
\text { (cm bgs) }\end{array}$} & \multicolumn{5}{|c|}{ COPCs (pCi/g) } \\
\hline & & & Ac-228 & Am-241 & Co-60 & Cs-137 & Eu-152 \\
\hline \multirow{4}{*}{$A$} & $367 \mathrm{~A} 01$ & $0-5$ & 1.33 & 25.8 & 0.685 & 46.4 & -- \\
\hline & $367 \mathrm{~A} 02$ & $0-5$ & 1.2 & 21.4 & 0.706 & 46 & 0.5 \\
\hline & $367 \mathrm{~A} 03$ & $0-5$ & 1.21 & 28.1 & 0.72 & 50.8 & 0.4 \\
\hline & 367A04 & $0-5$ & 1.33 & 25.9 & 0.681 & 43.9 & 0.5 \\
\hline \multirow{4}{*}{ B } & 367B01 & $0-5$ & 1.38 & 9 & 0.238 & 16.2 & -- \\
\hline & 367B02 & $0-5$ & 1.32 & 12.3 & 0.326 & 20.8 & -- \\
\hline & 367B03 & $0-5$ & 1.34 & 8.1 & 0.249 & 15.7 & -- \\
\hline & 367B04 & $0-5$ & 1.28 & 8.1 & 0.237 & 14.8 & -- \\
\hline \multirow{4}{*}{$\mathrm{C}$} & $367 \mathrm{C01}$ & $0-5$ & 1.33 & 10.3 & 0.298 & 19.7 & -- \\
\hline & $367 \mathrm{C} 02$ & $0-5$ & 1.4 & 10.9 & 0.257 & 17.8 & -- \\
\hline & $367 \mathrm{C} 03$ & $0-5$ & 1.4 & 11.2 & 0.313 & 19.7 & -- \\
\hline & $367 \mathrm{C0} 04$ & $0-5$ & 1.34 & $11.2(\mathrm{~J})$ & 0.308 & 19.7 & -- \\
\hline \multirow{4}{*}{$\mathrm{D}$} & 367D01 & $0-5$ & 1.57 & $8(\mathrm{~J})$ & 0.165 & 15.6 & $0.292(\mathrm{~J})$ \\
\hline & 367D02 & $0-5$ & 1.36 & 8.8 & 0.162 & 17 & -- \\
\hline & 367D03 & $0-5$ & 1.52 & 7.9 & 0.21 & 17.8 & 0.36 \\
\hline & 367D04 & $0-5$ & 1.44 & $7.9(\mathrm{~J})$ & 0.184 & 15.4 & -- \\
\hline
\end{tabular}

$\mathrm{J}=$ Estimated value

-- = Not detected above MDC 
Table F.1-2

Isotopic Sample Results for Radionuclides Detected above MDCs at Northeast Vector

\begin{tabular}{|c|c|c|c|c|c|c|c|c|c|}
\hline \multirow{2}{*}{$\begin{array}{c}\text { Sample } \\
\text { Plot }\end{array}$} & \multirow{2}{*}{$\begin{array}{l}\text { Sample } \\
\text { Number }\end{array}$} & \multirow{2}{*}{$\begin{array}{c}\text { Depth } \\
\text { (cm bgs) }\end{array}$} & \multicolumn{7}{|c|}{ COPCs (pCi/g) } \\
\hline & & & Am-241 & Pu-238 & $\mathrm{Pu}-239 / 240$ & Sr-90 & U-234 & U-235 & U-238 \\
\hline \multirow{4}{*}{ A } & 367A01 & $0-5$ & 28.5 & 17.4 & 111 & $8(\mathrm{~J})$ & 2.08 & -- & 1.05 \\
\hline & 367A02 & $0-5$ & 24.6 & 13.5 & 87 & $8.3(\mathrm{~J})$ & 1.79 & 0.109 & 0.8 \\
\hline & $367 \mathrm{~A} 03$ & $0-5$ & 24.7 & 11.6 & 69 & $6(\mathrm{~J})$ & 1.65 & -- & 0.74 \\
\hline & 367A04 & $0-5$ & 27 & 15.2 & 104 & $8.6(\mathrm{~J})$ & 2.02 & -- & 0.73 \\
\hline \multirow{4}{*}{ B } & 367B01 & $0-5$ & 11 & 6.2 & 41 & $1.72(\mathrm{~J})$ & 1.03 & -- & 0.71 \\
\hline & 367B02 & $0-5$ & 9.2 & 6.2 & 42 & $1.99(\mathrm{~J})$ & 1.09 & -- & 0.75 \\
\hline & 367B03 & $0-5$ & 5.26 & 3.65 & 24.4 & $1.71(\mathrm{~J})$ & 1.17 & -- & 0.82 \\
\hline & 367B04 & $0-5$ & 21.2 & 14.1 & 88 & $1.41(\mathrm{~J})$ & 1.72 & 0.072 & 0.92 \\
\hline \multirow{4}{*}{ C } & 367C01 & $0-5$ & 12.4 & 7.1 & 46.2 & $4.9(\mathrm{~J})$ & 1.1 & -- & 0.87 \\
\hline & 367C02 & $0-5$ & 12.1 & 7 & 55.4 & $4.1(\mathrm{~J})$ & 1 & -- & 0.86 \\
\hline & $367 C 03$ & $0-5$ & 8.5 & 4.97 & 32.1 & $7.1(\mathrm{~J})$ & 1.11 & -- & 0.84 \\
\hline & $367 \mathrm{C} 04$ & $0-5$ & 0.56 & 0.31 & 2.59 & $5(\mathrm{~J})$ & 0.281 & -- & 0.245 \\
\hline \multirow{4}{*}{ D } & 367D01 & $0-5$ & 8.6 & 3.43 & 38.8 & $5.9(\mathrm{~J})$ & 1.29 & -- & 0.89 \\
\hline & 367D02 & $0-5$ & 9.9 & 5.25 & 42.3 & $5.3(\mathrm{~J})$ & 1.17 & -- & 0.7 \\
\hline & 367D03 & $0-5$ & 8.3 & 5.2 & 39.5 & 5.7 & 1.1 & 0.06 & 0.84 \\
\hline & 367D04 & $0-5$ & 6.3 & 3.63 & 32.3 & $4.9(\mathrm{~J})$ & 1.17 & -- & 0.69 \\
\hline
\end{tabular}

$\mathrm{J}=$ Estimated value

-- = Not detected above MDC 
Table F.1-3

Gamma Spectroscopy Sample Results for Radionuclides Detected above MDCs at East Vector

\begin{tabular}{|c|c|c|c|c|c|c|c|}
\hline \multirow{2}{*}{$\begin{array}{c}\text { Sample } \\
\text { Plot }\end{array}$} & \multirow{2}{*}{$\begin{array}{l}\text { Sample } \\
\text { Number }\end{array}$} & \multirow{2}{*}{$\begin{array}{c}\text { Depth } \\
\text { (cm bgs) }\end{array}$} & \multicolumn{5}{|c|}{ COPCs (pCi/g) } \\
\hline & & & Ac-228 & Am-241 & Co-60 & Cs-137 & Eu-152 \\
\hline \multirow{5}{*}{$E$} & 367E01 & $0-5$ & 1.26 & $35.1(\mathrm{~J})$ & 0.87 & 48.3 & $0.63(\mathrm{~J})$ \\
\hline & 367E02 & $0-5$ & 1.3 & 30.1 & 0.83 & 46.4 & 0.64 \\
\hline & 367E03 & $0-5$ & 1.19 & $32(\mathrm{~J})$ & 0.82 & 44.1 & $0.58(\mathrm{~J})$ \\
\hline & 367E04 & $0-5$ & 1.28 & $31.6(\mathrm{~J})$ & 0.88 & 46.1 & $0.63(\mathrm{~J})$ \\
\hline & 367E05 & $0-5$ & 1.19 & $33.9(\mathrm{~J})$ & 0.84 & 45.5 & $0.59(\mathrm{~J})$ \\
\hline \multirow{4}{*}{$\mathrm{F}$} & 367F01 & $0-5$ & 1.35 & $39(\mathrm{~J})$ & 1.09 & 51.3 & $0.71(\mathrm{~J})$ \\
\hline & 367F02 & $0-5$ & 1.29 & 38.7 & 0.95 & 48.7 & 0.72 \\
\hline & $367 F 03$ & $0-5$ & 1.25 & 36 & 1.04 & 53.1 & 0.89 \\
\hline & 367F04 & $0-5$ & 1.14 & $41.8(\mathrm{~J})$ & 0.99 & 51.5 & $0.76(\mathrm{~J})$ \\
\hline \multirow{4}{*}{ G } & 367G01 & $0-5$ & 1.4 & $40.4(\mathrm{~J})$ & 1.14 & 50.8 & $1.04(\mathrm{~J})$ \\
\hline & 367G02 & $0-5$ & 1.4 & $39.3(\mathrm{~J})$ & 0.98 & 43.9 & $0.81(\mathrm{~J})$ \\
\hline & 367G03 & $0-5$ & 1.02 & $48.8(\mathrm{~J})$ & 1.21 & 54.9 & $0.98(\mathrm{~J})$ \\
\hline & $367 G 04$ & $0-5$ & 1.38 & $43(\mathrm{~J})$ & 1.16 & 50.8 & $0.92(\mathrm{~J})$ \\
\hline \multirow{4}{*}{$\mathrm{H}$} & 367H01 & $0-5$ & 1.56 & $11.1(\mathrm{~J})$ & 0.271 & 19.5 & -- \\
\hline & 367H02 & $0-5$ & 1.6 & $8.7(\mathrm{~J})$ & 0.193 & 16.9 & -- \\
\hline & 367H03 & $0-5$ & 1.54 & $16.5(\mathrm{~J})$ & 0.332 & 24.6 & -- \\
\hline & $367 \mathrm{H0} 4$ & $0-5$ & 1.52 & 9.1 & 0.255 & 17.7 & -- \\
\hline
\end{tabular}

$\mathrm{J}=$ Estimated value

-- = Not detected above MDC 
Table F.1-4

Isotopic Sample Results for Radionuclides

Detected above MDCs at East Vector

\begin{tabular}{|c|c|c|c|c|c|c|c|c|c|}
\hline \multirow{2}{*}{$\begin{array}{l}\text { Sample } \\
\text { Plot }\end{array}$} & \multirow{2}{*}{$\begin{array}{l}\text { Sample } \\
\text { Number }\end{array}$} & \multirow{2}{*}{$\begin{array}{c}\text { Depth } \\
\text { (cm bgs) }\end{array}$} & \multicolumn{7}{|c|}{ COPCs (pCi/g) } \\
\hline & & & Am-241 & Pu-238 & Pu-239/240 & Sr-90 & U-234 & U-235 & U-238 \\
\hline \multirow{5}{*}{$E$} & 367E01 & $0-5$ & $29.3(\mathrm{~J})$ & 16.8 & 108 & 6.2 & 1.76 & -- & 0.83 \\
\hline & 367E02 & $0-5$ & 25.5 & 15.7 & 99 & 5 & 1.98 & -- & 0.92 \\
\hline & 367E03 & $0-5$ & 24.1 & 12.4 & 87 & 4.5 & 1.69 & -- & 0.81 \\
\hline & 367E04 & $0-5$ & 28.9 & 13.7 & 98 & 5.7 & 1.75 & -- & 0.76 \\
\hline & 367E05 & $0-5$ & 24 & 15.1 & 95 & 5.8 & 1.77 & 0.093 & 0.86 \\
\hline \multirow{4}{*}{$F$} & 367F01 & $0-5$ & 29.7 & 15 & 100 & 6.2 & 1.86 & -- & 0.87 \\
\hline & 367F02 & $0-5$ & 29.8 & 15.2 & 105 & 5 & 1.97 & -- & 0.75 \\
\hline & 367F03 & $0-5$ & 32.2 & 18.9 & 126 & 7.1 & 2.12 & 0.06 & 0.7 \\
\hline & 367F04 & $0-5$ & 32 & 18.3 & 119 & 6.6 & 1.7 & -- & 0.83 \\
\hline \multirow{4}{*}{ G } & 367G01 & $0-5$ & 42.7 & 21.7 & 153 & 6.4 & 2.65 & -- & 0.84 \\
\hline & 367G02 & $0-5$ & 34.3 & 17.4 & 117 & 6.9 & 1.98 & -- & 0.76 \\
\hline & $367 G 03$ & $0-5$ & 43.2 & 19 & 132 & $12.2(\mathrm{~J})$ & 2.25 & -- & 0.8 \\
\hline & 367G04 & $0-5$ & 39.9 & 21.4 & 148 & 7.3 & 2.11 & 0.081 & 0.82 \\
\hline \multirow{4}{*}{$\mathrm{H}$} & 367H01 & $0-5$ & 12.1 & 5.8 & 41 & 5.2 & 1.21 & -- & 0.68 \\
\hline & 367H02 & $0-5$ & 8.4 & 4.93 & 33.9 & 4.2 & 0.96 & -- & 0.55 \\
\hline & 367H03 & $0-5$ & 13.7 & 7.9 & 52.4 & 4.8 & 1.3 & -- & 0.77 \\
\hline & 367H04 & $0-5$ & 9 & 5.7 & 36.9 & 4 & 1.07 & -- & 0.69 \\
\hline
\end{tabular}

$\mathrm{J}=$ Estimated value

-- = Not detected above MDC 
Table F.1-5

Gamma Spectroscopy Sample Results for Radionuclides Detected above MDCs at South Vector

(Page 1 of 2)

\begin{tabular}{|c|c|c|c|c|c|c|c|c|}
\hline \multirow{2}{*}{$\begin{array}{c}\text { Sample } \\
\text { Plot }\end{array}$} & \multirow{2}{*}{$\begin{array}{l}\text { Sample } \\
\text { Number }\end{array}$} & \multirow{2}{*}{$\begin{array}{c}\text { Depth } \\
\text { (cm bgs) }\end{array}$} & \multicolumn{6}{|c|}{ COPCs (pCi/g) } \\
\hline & & & Ac-228 & Am-241 & Co-60 & Cs-137 & Eu-152 & Eu-154 \\
\hline \multirow{4}{*}{$\mathrm{J}$} & $367 J 01$ & $0-5$ & 1.3 & 16.2 & 0.414 & 26.1 & -- & -- \\
\hline & $367 J 02$ & $0-5$ & 1.3 & 16.5 & 0.472 & 33.7 & 0.35 & -- \\
\hline & 367J03 & $0-5$ & 1.43 & 18 & 0.471 & 31.7 & -- & -- \\
\hline & 367J04 & $0-5$ & 1.29 & 14.4 & 0.384 & 27.1 & -- & -- \\
\hline \multirow{18}{*}{$\mathrm{K}^{\mathrm{a}}$} & 367K01 & \multirow{2}{*}{$0-5$} & 1.49 & $17.3(\mathrm{~J})$ & 0.413 & 76.8 & $1.43(\mathrm{~J})$ & -- \\
\hline & 367K01RE & & NA & NA & NA & NA & NA & NA \\
\hline & 367K02 & \multirow{2}{*}{$0-5$} & 1.46 & 9.3 & 0.27 & 90 & $1.55(\mathrm{~J})$ & -- \\
\hline & 367K02RE & & NA & NA & NA & NA & NA & NA \\
\hline & $367 \mathrm{~K} 03$ & \multirow{2}{*}{$0-5$} & 1.35 & $12(\mathrm{~J})$ & 0.292 & 79.4 & $1.77(\mathrm{~J})$ & -- \\
\hline & 367K03RE & & NA & NA & NA & NA & NA & NA \\
\hline & 367K04 & \multirow{2}{*}{$0-5$} & 1.49 & 9.8 & 0.299 & 84.8 & $1.52(\mathrm{~J})$ & -- \\
\hline & 367K04RE & & NA & NA & NA & NA & NA & NA \\
\hline & 367K05 & \multirow{2}{*}{$0-5$} & 1.56 & 11.2 & 0.309 & 82.4 & $1.73(\mathrm{~J})$ & -- \\
\hline & 367K05RE & & NA & NA & NA & NA & NA & NA \\
\hline & 367K06 & \multirow{2}{*}{$5-25$} & 1.74 & 2.98 & 0.092 & 130 & 4.77 & -- \\
\hline & 367K06RE & & 1.54 & 2.06 & 0.128 & 115 & 3.95 & -- \\
\hline & 367K07 & \multirow{2}{*}{$5-25$} & 1.81 & -- & -- & 148 & $4.04(\mathrm{~J})$ & -- \\
\hline & 367K07RE & & 1.63 & -- & 0.0578 & 131 & 3.17 & -- \\
\hline & $367 \mathrm{~K} 08$ & \multirow{2}{*}{$5-25$} & 1.47 & 4.81 & 0.186 & 120 & 2.96 & -- \\
\hline & 367K08RE & & 1.36 & 4.02 & 0.131 & 114 & 2.7 & 0.178 \\
\hline & 367K09 & \multirow{2}{*}{$5-20$} & 1.8 & $2.47(\mathrm{~J})$ & 0.098 & 128 & $3.19(\mathrm{~J})$ & -- \\
\hline & 367K09RE & & 1.71 & 2.16 & 0.104 & 119 & 2.8 & -- \\
\hline
\end{tabular}


Table F.1-5

Gamma Spectroscopy Sample Results for Radionuclides Detected above MDCs at South Vector

(Page 2 of 2)

\begin{tabular}{|c|c|c|c|c|c|c|c|c|}
\hline \multirow{2}{*}{$\begin{array}{c}\text { Sample } \\
\text { Plot }\end{array}$} & \multirow{2}{*}{$\begin{array}{l}\text { Sample } \\
\text { Number }\end{array}$} & \multirow{2}{*}{$\begin{array}{c}\text { Depth } \\
\text { (cm bgs) }\end{array}$} & \multicolumn{6}{|c|}{ COPCs (pCi/g) } \\
\hline & & & Ac-228 & Am-241 & Co-60 & Cs-137 & Eu-152 & Eu-154 \\
\hline \multirow{8}{*}{$\mathrm{L}^{\mathrm{a}}$} & 367L01 & \multirow{2}{*}{$0-5$} & 1.47 & $3.42(\mathrm{~J})$ & 0.105 & 76.2 & $0.98(\mathrm{~J})$ & - \\
\hline & 367L01RE & & NA & NA & NA & NA & NA & NA \\
\hline & 367L02 & \multirow{2}{*}{$0-5$} & 1.51 & 2.7 & 0.107 & 84.8 & $1.21(\mathrm{~J})$ & -- \\
\hline & 367L02RE & & NA & NA & NA & NA & NA & NA \\
\hline & 367L03 & \multirow{2}{*}{$0-5$} & 1.41 & $2.08(\mathrm{~J})$ & 0.095 & 78.5 & $1.04(\mathrm{~J})$ & -- \\
\hline & 367L03RE & & NA & NA & NA & NA & NA & NA \\
\hline & 367L04 & \multirow{2}{*}{$0-5$} & 1.62 & $4.1(\mathrm{~J})$ & 0.115 & 99 & $1.14(\mathrm{~J})$ & -- \\
\hline & 367L04RE & & NA & NA & NA & NA & NA & NA \\
\hline \multirow{6}{*}{$M^{a}$} & 367M01 & $0-5$ & 1.49 & -- & -- & 1.82 & -- & -- \\
\hline & 367M02 & \multirow{2}{*}{$0-5$} & 1.71 & $0.72(\mathrm{~J})$ & -- & 2.21 & -- & -- \\
\hline & 367M02RE & & NA & NA & NA & NA & NA & NA \\
\hline & 367M03 & $0-5$ & 1.6 & -- & -- & 1.84 & -- & -- \\
\hline & $367 \mathrm{M} 04$ & $0-5$ & 1.48 & -- & -- & 1.49 & -- & -- \\
\hline & 367M05 & $0-5$ & 1.68 & -- & -- & 1.44 & -- & -- \\
\hline
\end{tabular}

${ }^{a}$ All soil samples from sample plots $K$ and $L$ and one sample from sample plot $\mathrm{M}$ (367M02) were reanalyzed for isotopic Pu and isotopic Am. The subsurface soil samples from sample plot K (367K06-K09) also were reanalyzed by gamma spectroscopy (see Section A.3.2.1.2).

$$
\begin{aligned}
& \mathrm{J}=\text { Estimated value } \\
& \mathrm{NA}=\text { Not analyzed } \\
& --=\text { Not detected above MDC }
\end{aligned}
$$


Table F.1-6

Isotopic Sample Results for Radionuclides

Detected above MDCs at South Vector

(Page 1 of 2)

\begin{tabular}{|c|c|c|c|c|c|c|c|c|c|}
\hline \multirow{2}{*}{$\begin{array}{c}\text { Sample } \\
\text { Plot }\end{array}$} & \multirow{2}{*}{$\begin{array}{l}\text { Sample } \\
\text { Number }\end{array}$} & \multirow{2}{*}{$\begin{array}{c}\text { Depth } \\
\text { (cm bgs) }\end{array}$} & \multicolumn{7}{|c|}{ COPCs (pCi/g) } \\
\hline & & & Am-241 & Pu-238 & $\mathrm{Pu}-239 / 240$ & Sr-90 & U-234 & U-235 & U-238 \\
\hline \multirow{4}{*}{$\mathrm{J}$} & $367 J 01$ & $0-5$ & 14.1 & 6 & 40.9 & 3.34 & 1.34 & -- & 0.73 \\
\hline & $367 J 02$ & $0-5$ & 11.7 & 9.4 & 63.2 & 3.32 & 1.24 & 0.084 & 0.96 \\
\hline & 367J03 & $0-5$ & 11.6 & 7.7 & 49.3 & 3.63 & 1.23 & 0.045 & 0.81 \\
\hline & $367 J 04$ & $0-5$ & 11.7 & 5.9 & 42.6 & 4.5 & 1.31 & -- & 0.93 \\
\hline \multirow{18}{*}{$\mathrm{K}^{\mathrm{a}}$} & 367K01 & \multirow{2}{*}{$0-5$} & 13.5 & 7.7 & 85 & 19.2 & 4.25 & 0.124 & 1.08 \\
\hline & 367K01RE & & 13 & 7.2 & 70 & NA & NA & NA & NA \\
\hline & $367 \mathrm{~K} 02$ & \multirow{2}{*}{$0-5$} & 10.1 & 6.1 & 67 & 30 & 3.13 & 0.097 & 1.06 \\
\hline & $367 \mathrm{~K} 02 \mathrm{RE}$ & & 8.8 & 5.52 & 70 & NA & NA & NA & NA \\
\hline & 367K03 & \multirow{2}{*}{$0-5$} & 9.1 & 5.5 & 64 & 21.4 & 3.61 & 0.131 & 1.05 \\
\hline & 367K03RE & & 10.3 & 5.22 & 72 & NA & NA & NA & NA \\
\hline & 367K04 & \multirow{2}{*}{$0-5$} & 10.3 & 5.7 & 73 & 22 & 3.93 & 0.158 & 1.03 \\
\hline & 367K04RE & & 11.8 & 6.9 & 87 & NA & NA & NA & NA \\
\hline & 367K05 & \multirow{2}{*}{$0-5$} & 11.9 & 6.9 & 91 & 22.8 & 4.56 & 0.173 & 1.06 \\
\hline & 367K05RE & & 9.7 & 5.1 & 105 & NA & NA & NA & NA \\
\hline & $367 \mathrm{~K} 06$ & \multirow{2}{*}{$5-25$} & 2.15 & 1.14 & 108 & 14.1 & 11.4 & $0.46(\mathrm{~J})$ & 1.49 \\
\hline & 367K06RE & & 1.2 & -- & 37.1 & NA & NA & NA & NA \\
\hline & 367K07 & \multirow{2}{*}{$5-25$} & 0.103 & 0.077 & 46.9 & 19.1 & 4.93 & $0.17(\mathrm{~J})$ & 1.01 \\
\hline & 367K07RE & & -- & -- & $39.6(\mathrm{~J})$ & NA & NA & NA & NA \\
\hline & $367 \mathrm{~K} 08$ & \multirow{2}{*}{$5-25$} & 4.91 & 2.82 & 77 & 16.5 & 7.1 & $0.25(\mathrm{~J})$ & 1.14 \\
\hline & 367K08RE & & 2.26 & $1.91(\mathrm{~J})$ & $46.3(\mathrm{~J})$ & NA & NA & NA & NA \\
\hline & 367K09 & \multirow{2}{*}{$5-20$} & 1.75 & 0.99 & 58 & 13.2 & 5.01 & $0.19(\mathrm{~J})$ & 1.26 \\
\hline & 367K09RE & & $1.83(\mathrm{~J})$ & $2.36(\mathrm{~J})$ & $41.2(\mathrm{~J})$ & NA & NA & NA & NA \\
\hline
\end{tabular}


Table F.1-6

Isotopic Sample Results for Radionuclides

Detected above MDCs at South Vector

(Page 2 of 2)

\begin{tabular}{|c|c|c|c|c|c|c|c|c|c|}
\hline \multirow{2}{*}{$\begin{array}{c}\text { Sample } \\
\text { Plot }\end{array}$} & \multirow{2}{*}{$\begin{array}{l}\text { Sample } \\
\text { Number }\end{array}$} & \multirow{2}{*}{$\begin{array}{c}\text { Depth } \\
\text { (cm bgs) }\end{array}$} & \multicolumn{7}{|c|}{ COPCs (pCi/g) } \\
\hline & & & Am-241 & Pu-238 & $\mathrm{Pu}-239 / 240$ & Sr-90 & U-234 & U-235 & U-238 \\
\hline \multirow{8}{*}{$\mathrm{L}^{\mathrm{a}}$} & 367L01 & \multirow{2}{*}{$0-5$} & 2.75 & 1.68 & 41.1 & 18.2 & 3.41 & 0.143 & 1.05 \\
\hline & 367L01RE & & 3.51 & 1.92 & 39.9 & NA & NA & NA & NA \\
\hline & 367L02 & \multirow{2}{*}{$0-5$} & 3.08 & 1.84 & 46.6 & 20.2 & 3.51 & 0.16 & 1.04 \\
\hline & 367L02RE & & 2.58 & 1.51 & 33.7 & NA & NA & NA & NA \\
\hline & 367L03 & \multirow{2}{*}{$0-5$} & 1.75 & 1.22 & 28.3 & 19.7 & 2.33 & 0.11 & 0.92 \\
\hline & 367L03RE & & 1.89 & 1.11 & 31.5 & NA & NA & NA & NA \\
\hline & 367L04 & \multirow{2}{*}{$0-5$} & 3.39 & 2.1 & 41.5 & 24.3 & 2.78 & 0.149 & 1 \\
\hline & 367L04RE & & 3.93 & 2.47 & 45.7 & NA & NA & NA & NA \\
\hline \multirow{6}{*}{$M^{a}$} & 367M01 & $0-5$ & 0.55 & 0.36 & 3.04 & -- & 0.9 & 0.049 & 0.77 \\
\hline & 367M02 & \multirow{2}{*}{$0-5$} & 0.73 & 0.34 & 5.45 & -- & 0.91 & 0.025 & 0.77 \\
\hline & 367M02RE & & 0.7 & 0.43 & 4.75 & NA & NA & NA & NA \\
\hline & $367 \mathrm{M} 03$ & $0-5$ & 0.37 & 0.266 & 2.09 & -- & 0.84 & 0.046 & 0.81 \\
\hline & $367 \mathrm{M} 04$ & $0-5$ & 0.35 & 0.215 & 1.81 & -- & 0.78 & 0.036 & 0.81 \\
\hline & 367M05 & $0-5$ & 0.41 & 0.211 & 2.02 & -- & 0.81 & 0.044 & 0.81 \\
\hline
\end{tabular}

${ }^{a}$ All soil samples from sample plots $\mathrm{K}$ and $\mathrm{L}$ and one sample from sample plot $\mathrm{M}$ (367M02) were reanalyzed for isotopic $\mathrm{Pu}$ and isotopic Am. The subsurface soil samples from sample plot K (367K06-K09) also were reanalyzed by gamma spectroscopy (see Section A.3.2.1.2).

$\mathrm{J}=$ Estimated value

NA = Not analyzed

-- = Not detected above MDC 
Table F.1-7

Gamma Spectroscopy Sample Results for Radionuclides Detected above MDCs at Northwest Vector

\begin{tabular}{|c|c|c|c|c|c|c|c|c|}
\hline \multirow{2}{*}{$\begin{array}{c}\text { Sample } \\
\text { Plot }\end{array}$} & \multirow{2}{*}{$\begin{array}{l}\text { Sample } \\
\text { Number }\end{array}$} & \multirow{2}{*}{$\begin{array}{c}\text { Depth } \\
\text { (cm bgs) }\end{array}$} & \multicolumn{6}{|c|}{ COPCs (pCi/g) } \\
\hline & & & Ac-228 & Am-241 & Co-60 & Cs-137 & Eu-152 & Th-234 \\
\hline \multirow{4}{*}{$\mathrm{N}$} & $367 N 01$ & $0-5$ & 1.42 & 24 & 0.574 & 39.7 & -- & -- \\
\hline & 367N02 & $0-5$ & 1.32 & $21.6(\mathrm{~J})$ & 0.467 & 37.2 & $0.42(\mathrm{~J})$ & -- \\
\hline & 367N03 & $0-5$ & 1.47 & 26.2 & 0.635 & 43.1 & 0.49 & -- \\
\hline & 367N04 & $0-5$ & 1.25 & 23.8 & 0.555 & 41.5 & -- & -- \\
\hline \multirow{4}{*}{$\mathrm{P}$} & 367P01 & $0-5$ & 1.28 & $12.8(\mathrm{~J})$ & 0.264 & 24.3 & -- & -- \\
\hline & 367P02 & $0-5$ & 1.25 & 11.7 & 0.213 & 21.1 & -- & -- \\
\hline & 367P03 & $0-5$ & 1.4 & $14.3(\mathrm{~J})$ & 0.328 & 24.8 & -- & -- \\
\hline & 367P04 & $0-5$ & 1.2 & 13 & 0.321 & 25.6 & -- & -- \\
\hline \multirow{5}{*}{$\mathrm{Q}$} & 367Q01 & $0-5$ & 1.15 & 1.6 & -- & 2.02 & -- & 1.48 \\
\hline & 367Q02 & $0-5$ & 1.1 & $1.14(\mathrm{~J})$ & -- & 1.27 & -- & -- \\
\hline & 367Q03 & $0-5$ & 1.09 & $1.14(\mathrm{~J})$ & -- & 1.23 & -- & -- \\
\hline & 367Q04 & $0-5$ & 1.12 & 0.98 & -- & 1.13 & -- & 1.51 \\
\hline & 367Q05 & $0-5$ & 1.23 & -- & -- & 1.25 & -- & -- \\
\hline \multirow{4}{*}{$\mathrm{R}$} & 367R01 & $0-5$ & 1.36 & $34.2(\mathrm{~J})$ & 0.651 & 33.5 & $0.58(\mathrm{~J})$ & 2.5 \\
\hline & 367R02 & $0-5$ & 1.2 & $24.7(\mathrm{~J})$ & 0.495 & 26.9 & -- & -- \\
\hline & 367R03 & $0-5$ & 1.26 & 26.9 & 0.645 & 34.9 & 0.59 & -- \\
\hline & 367R04 & $0-5$ & 1.35 & 22.7 & 0.534 & 29.8 & 0.35 & -- \\
\hline
\end{tabular}

$\mathrm{J}=$ Estimated value

-- = Not detected above MDC

Th $=$ Thorium 
Table F.1-8

Isotopic Sample Results for Radionuclides Detected above MDCs at Northwest Vector

\begin{tabular}{|c|c|c|c|c|c|c|c|c|c|}
\hline \multirow{2}{*}{$\begin{array}{c}\text { Sample } \\
\text { Plot }\end{array}$} & \multirow{2}{*}{$\begin{array}{l}\text { Sample } \\
\text { Number }\end{array}$} & \multirow{2}{*}{$\begin{array}{c}\text { Depth } \\
\text { (cm bgs) }\end{array}$} & \multicolumn{7}{|c|}{ COPCs (pCi/g) } \\
\hline & & & Am-241 & Pu-238 & $\mathrm{Pu}-239 / 240$ & Sr-90 & U-234 & U-235 & U-238 \\
\hline \multirow{4}{*}{$\mathrm{N}$} & 367 N01 & $0-5$ & $22.1(\mathrm{~J})$ & $13.7(\mathrm{~J})$ & 96 & 6.9 & 1.49 & -- & 0.75 \\
\hline & $367 \mathrm{~N} 02$ & $0-5$ & $14.8(\mathrm{~J})$ & $9.7(\mathrm{~J})$ & 62.5 & 5.7 & 1.36 & 0.064 & 0.79 \\
\hline & 367 N03 & $0-5$ & $17.9(\mathrm{~J})$ & $11.1(\mathrm{~J})$ & 74 & 7.9 & 1.53 & -- & 0.82 \\
\hline & 367 N04 & $0-5$ & $25.1(\mathrm{~J})$ & $13.3(\mathrm{~J})$ & 92 & 6.7 & 1.6 & -- & 0.83 \\
\hline \multirow{4}{*}{$\mathrm{P}$} & 367P01 & $0-5$ & $10.2(\mathrm{~J})$ & $7.8(\mathrm{~J})$ & 46.1 & 3.09 & 1.06 & -- & 0.75 \\
\hline & 367P02 & $0-5$ & $10.7(\mathrm{~J})$ & $6.2(\mathrm{~J})$ & 41.7 & 3.21 & 1.21 & -- & 0.84 \\
\hline & 367P03 & $0-5$ & $10.4(\mathrm{~J})$ & $7.4(\mathrm{~J})$ & 46.8 & 4.1 & 1.11 & -- & 0.76 \\
\hline & 367P04 & $0-5$ & $9.7(\mathrm{~J})$ & $5.9(\mathrm{~J})$ & 36.1 & 2.98 & 1.15 & -- & 0.93 \\
\hline \multirow{5}{*}{$\mathrm{Q}$} & 367Q01 & $0-5$ & $0.88(\mathrm{~J})$ & $0.82(\mathrm{~J})$ & 5.16 & -- & 0.87 & 0.043 & 0.78 \\
\hline & 367Q02 & $0-5$ & $0.58(\mathrm{~J})$ & $0.47(\mathrm{~J})$ & 2.71 & -- & 0.85 & 0.029 & 0.78 \\
\hline & 367Q03 & $0-5$ & $0.59(\mathrm{~J})$ & $0.33(\mathrm{~J})$ & 2.65 & -- & 0.8 & 0.06 & 0.85 \\
\hline & 367Q04 & $0-5$ & $1(\mathrm{~J})$ & $0.75(\mathrm{~J})$ & 3.43 & -- & 0.87 & 0.062 & 0.84 \\
\hline & $367 Q 05$ & $0-5$ & $0.46(\mathrm{~J})$ & $0.37(\mathrm{~J})$ & 2.12 & -- & 0.79 & 0.034 & 0.87 \\
\hline \multirow{4}{*}{$\mathrm{R}$} & 367R01 & $0-5$ & $27.8(\mathrm{~J})$ & $15.6(\mathrm{~J})$ & 100 & 2.65 & 1.77 & 0.059 & 0.84 \\
\hline & 367R02 & $0-5$ & $19.7(\mathrm{~J})$ & $11.9(\mathrm{~J})$ & 75 & 1.91 & 1.23 & 0.05 & 0.83 \\
\hline & 367R03 & $0-5$ & 41.2 & 23.6 & 155 & 3.8 & 1.79 & -- & 0.82 \\
\hline & 367R04 & $0-5$ & 21 & 15.9 & 95 & 2.16 & 1.44 & -- & 0.79 \\
\hline
\end{tabular}

$\mathrm{J}=$ Estimated value

-- = Not detected above MDC 
Table F.1-9

Thermoluminescent Dosimeter Results for CAU 367 (mrem)

(Page 1 of 4)

\begin{tabular}{|c|c|c|c|c|c|c|c|c|c|c|}
\hline \multirow{3}{*}{$\begin{array}{c}\text { Sample } \\
\text { Plot }\end{array}$} & \multirow{3}{*}{$\begin{array}{c}\text { TLD } \\
\text { Location }\end{array}$} & \multicolumn{3}{|c|}{ TLD 1} & \multicolumn{3}{|c|}{ TLD 2} & \multicolumn{3}{|c|}{ TLD 3} \\
\hline & & \multicolumn{3}{|c|}{ Element } & \multicolumn{3}{|c|}{ Element } & \multicolumn{3}{|c|}{ Element } \\
\hline & & 2 & 3 & 4 & 2 & 3 & 4 & 2 & 3 & 4 \\
\hline $\mathrm{N}$ & AT01 & $1.04 \mathrm{E}+02$ & $9.00 \mathrm{E}+01$ & $8.97 \mathrm{E}+01$ & -- & -- & $\overline{--}$ & -- & $\overline{--}$ & - \\
\hline $\mathrm{P}$ & AT02 & $7.97 E+01$ & $7.77 E+01$ & $7.47 \mathrm{E}+01$ & -- & -- & -- & -- & -- & -- \\
\hline $\mathrm{Q}$ & AT03 & $4.67 E+01$ & $3.91 E+01$ & $4.04 \mathrm{E}+01$ & -- & -- & -- & -- & -- & -- \\
\hline No plot & AT04 & $5.11 \mathrm{E}+01$ & $4.53 E+01$ & $4.44 \mathrm{E}+01$ & -- & -- & -- & -- & -- & -- \\
\hline $\mathrm{R}$ & AT05 & $6.84 \mathrm{E}+01$ & $7.00 E+01$ & $7.09 E+01$ & -- & -- & -- & -- & -- & -- \\
\hline No plot & AT06 & $6.93 E+01$ & $5.45 E+01$ & $5.56 \mathrm{E}+01$ & -- & -- & -- & -- & -- & -- \\
\hline No plot & AT07 & $5.64 \mathrm{E}+01$ & $5.23 E+01$ & $5.15 \mathrm{E}+01$ & -- & -- & -- & -- & -- & -- \\
\hline No plot & AT08 & $4.71 E+01$ & $4.34 \mathrm{E}+01$ & $3.98 \mathrm{E}+01$ & -- & -- & -- & -- & -- & - \\
\hline No plot & AT09 & $5.74 \mathrm{E}+01$ & $5.62 E+01$ & $5.45 E+01$ & -- & -- & -- & -- & -- & -- \\
\hline No plot & AT10 & $8.21 E+01$ & $7.71 E+01$ & $6.82 \mathrm{E}+01$ & -- & -- & -- & -- & -- & - \\
\hline No plot & AT11 & $7.00 \mathrm{E}+01$ & $7.52 E+01$ & $7.37 \mathrm{E}+01$ & -- & -- & -- & -- & -- & - \\
\hline No plot & AT12 & $7.95 E+01$ & $7.55 E+01$ & $7.27 \mathrm{E}+01$ & -- & -- & -- & -- & -- & - \\
\hline No plot & AT13 & $6.41 E+01$ & $6.52 E+01$ & $6.43 E+01$ & -- & -- & -- & -- & -- & - \\
\hline No plot & AT14 & $5.49 \mathrm{E}+01$ & $5.39 E+01$ & $5.54 \mathrm{E}+01$ & -- & -- & -- & -- & -- & - \\
\hline No plot & AT15 & $4.42 E+01$ & $4.03 E+01$ & $3.94 \mathrm{E}+01$ & -- & -- & -- & -- & -- & - \\
\hline No plot & AT16 & $5.12 E+01$ & $4.64 E+01$ & $4.35 E+01$ & -- & -- & -- & -- & -- & - \\
\hline No plot & AT17 & $4.87 \mathrm{E}+01$ & $4.58 \mathrm{E}+01$ & $4.78 \mathrm{E}+01$ & -- & -- & -- & -- & -- & - \\
\hline No plot & AT18 & $5.66 \mathrm{E}+01$ & $5.42 \mathrm{E}+01$ & $5.23 \mathrm{E}+01$ & -- & -- & -- & - & -- & - \\
\hline
\end{tabular}


Table F.1-9

Thermoluminescent Dosimeter Results for CAU 367 (mrem)

(Page 2 of 4)

\begin{tabular}{|c|c|c|c|c|c|c|c|c|c|c|}
\hline \multirow{3}{*}{$\begin{array}{l}\text { Sample } \\
\text { Plot }\end{array}$} & \multirow{3}{*}{$\begin{array}{c}\text { TLD } \\
\text { Location }\end{array}$} & \multicolumn{3}{|c|}{ TLD 1} & \multicolumn{3}{|c|}{ TLD 2} & \multicolumn{3}{|c|}{ TLD 3} \\
\hline & & \multicolumn{3}{|c|}{ Element } & \multicolumn{3}{|c|}{ Element } & \multicolumn{3}{|c|}{ Element } \\
\hline & & 2 & 3 & 4 & 2 & 3 & 4 & 2 & 3 & 4 \\
\hline No plot & AT19 & $4.43 E+01$ & $4.54 \mathrm{E}+01$ & $4.20 \mathrm{E}+01$ & -- & -- & -- & -- & -- & -- \\
\hline No plot & AT20 & $7.29 E+01$ & $7.08 E+01$ & $7.33 E+01$ & -- & -- & -- & -- & -- & -- \\
\hline No plot & AT21 & $7.31 E+01$ & $7.60 E+01$ & $6.81 E+01$ & -- & -- & -- & -- & -- & -- \\
\hline No plot & AT22 & $6.73 E+01$ & $6.38 \mathrm{E}+01$ & $6.37 \mathrm{E}+01$ & -- & -- & -- & -- & -- & -- \\
\hline No plot & AT23 & $5.96 \mathrm{E}+01$ & $5.07 E+01$ & $5.49 E+01$ & -- & -- & -- & -- & -- & -- \\
\hline $\mathrm{J}$ & AT24 & $1.09 E+02$ & $1.13 E+02$ & $1.08 \mathrm{E}+02$ & -- & -- & -- & -- & -- & -- \\
\hline No plot & AT25 & $1.18 \mathrm{E}+02$ & $1.04 \mathrm{E}+02$ & $9.37 \mathrm{E}+01$ & $8.20 E+01$ & $8.06 \mathrm{E}+01$ & $7.82 E+01$ & 8.07E+01 & 7.77E+01 & $7.83 \mathrm{E}+01$ \\
\hline No plot & AT26 & $1.03 E+02$ & $1.04 \mathrm{E}+02$ & $1.06 \mathrm{E}+02$ & -- & -- & -- & -- & -- & -- \\
\hline No plot & AT27 & $5.05 E+01$ & $4.91 E+01$ & $4.71 E+01$ & -- & -- & -- & -- & -- & -- \\
\hline L & AT28 & $1.36 \mathrm{E}+02$ & $1.23 \mathrm{E}+02$ & $1.22 \mathrm{E}+02$ & -- & -- & -- & -- & -- & -- \\
\hline No plot & AT29 & $1.24 \mathrm{E}+02$ & $1.13 E+02$ & $1.05 \mathrm{E}+02$ & $8.80 E+01$ & $8.21 \mathrm{E}+01$ & $8.61 E+01$ & $8.21 E+01$ & $7.98 \mathrm{E}+01$ & $7.90 \mathrm{E}+01$ \\
\hline$M$ & AT30 & $4.89 E+01$ & $4.81 E+01$ & $4.38 \mathrm{E}+01$ & -- & -- & -- & -- & -- & -- \\
\hline No plot & AT31 & $6.40 E+01$ & $6.67 E+01$ & $6.07 \mathrm{E}+01$ & -- & -- & -- & -- & -- & -- \\
\hline No plot & AT32 & $5.33 E+01$ & $5.16 \mathrm{E}+01$ & $5.14 \mathrm{E}+01$ & -- & -- & -- & -- & -- & -- \\
\hline$E$ & AT33 & $1.15 E+02$ & $1.10 E+02$ & $1.14 \mathrm{E}+02$ & -- & -- & -- & -- & -- & -- \\
\hline $\mathrm{F}$ & AT34 & $1.28 \mathrm{E}+02$ & $1.21 E+02$ & $1.16 \mathrm{E}+02$ & -- & -- & -- & -- & -- & -- \\
\hline No plot & AT35 & $1.17 \mathrm{E}+02$ & $1.03 E+02$ & $9.65 E+01$ & $8.22 E+01$ & $7.76 \mathrm{E}+01$ & $7.72 E+01$ & $8.35 E+01$ & $7.67 \mathrm{E}+01$ & $8.31 E+01$ \\
\hline G & AT36 & $8.78 E+01$ & $8.09 E+01$ & $8.57 E+01$ & -- & -- & -- & -- & -- & -- \\
\hline
\end{tabular}


Table F.1-9

Thermoluminescent Dosimeter Results for CAU 367 (mrem)

(Page 3 of 4 )

\begin{tabular}{|c|c|c|c|c|c|c|c|c|c|c|}
\hline \multirow{3}{*}{$\begin{array}{l}\text { Sample } \\
\text { Plot }\end{array}$} & \multirow{3}{*}{$\begin{array}{c}\text { TLD } \\
\text { Location }\end{array}$} & \multicolumn{3}{|c|}{ TLD 1} & \multicolumn{3}{|c|}{ TLD 2} & \multicolumn{3}{|c|}{ TLD 3} \\
\hline & & \multicolumn{3}{|c|}{ Element } & \multicolumn{3}{|c|}{ Element } & \multicolumn{3}{|c|}{ Element } \\
\hline & & 2 & 3 & 4 & 2 & 3 & 4 & 2 & 3 & 4 \\
\hline No plot & AT37 & $8.07 E+01$ & $7.88 \mathrm{E}+01$ & $6.98 \mathrm{E}+01$ & -- & -- & -- & -- & -- & -- \\
\hline No plot & AT38 & $7.69 E+01$ & $6.63 E+01$ & $6.26 \mathrm{E}+01$ & -- & -- & -- & -- & -- & -- \\
\hline $\mathrm{H}$ & AT39 & $5.79 E+01$ & $5.48 E+01$ & $5.27 \mathrm{E}+01$ & -- & -- & -- & -- & -- & -- \\
\hline No plot & AT40 & $5.54 \mathrm{E}+01$ & $5.23 E+01$ & $5.02 E+01$ & -- & -- & -- & -- & -- & -- \\
\hline B & AT41 & $8.54 \mathrm{E}+01$ & $8.58 E+01$ & $8.38 E+01$ & -- & -- & -- & -- & -- & -- \\
\hline$A$ & AT42 & $1.16 \mathrm{E}+02$ & $1.08 \mathrm{E}+02$ & $1.01 E+02$ & -- & -- & -- & -- & -- & -- \\
\hline No plot & AT43 & $7.92 E+01$ & $7.48 \mathrm{E}+01$ & $7.28 \mathrm{E}+01$ & -- & -- & -- & -- & -- & -- \\
\hline C & AT44 & $6.20 E+01$ & $5.87 E+01$ & $6.27 E+01$ & -- & -- & -- & -- & -- & -- \\
\hline $\mathrm{D}$ & AT45 & $5.93 E+01$ & $5.93 E+01$ & $5.46 E+01$ & -- & -- & -- & -- & -- & -- \\
\hline No plot & AT46 & $5.47 E+01$ & $5.46 \mathrm{E}+01$ & $5.24 \mathrm{E}+01$ & -- & -- & -- & -- & -- & -- \\
\hline No plot & AT47 & $5.96 \mathrm{E}+01$ & $5.57 \mathrm{E}+01$ & $5.56 \mathrm{E}+01$ & -- & -- & -- & -- & -- & -- \\
\hline No plot & AT48 & $5.34 \mathrm{E}+01$ & $5.12 E+01$ & $5.02 E+01$ & -- & -- & -- & -- & -- & -- \\
\hline No plot & AT49 & $7.35 E+01$ & $7.64 \mathrm{E}+01$ & $7.11 E+01$ & -- & -- & -- & -- & -- & -- \\
\hline No plot & AT50 & $6.36 \mathrm{E}+01$ & $5.87 \mathrm{E}+01$ & $5.78 \mathrm{E}+01$ & -- & -- & -- & -- & -- & -- \\
\hline No plot & AT51 & $1.06 \mathrm{E}+02$ & $1.08 E+02$ & $9.33 E+01$ & -- & -- & -- & -- & -- & -- \\
\hline No plot & AT53 & $4.43 E+01$ & $4.07 E+01$ & $3.80 E+01$ & -- & -- & -- & -- & -- & -- \\
\hline No plot & AT54 & $4.59 E+01$ & $4.26 \mathrm{E}+01$ & $4.33 E+01$ & -- & -- & -- & -- & -- & -- \\
\hline $\mathrm{K}$ & AT55 & $1.47 E+02$ & $1.47 \mathrm{E}+02$ & $1.27 \mathrm{E}+02$ & $1.19 E+02$ & $1.19 \mathrm{E}+02$ & $1.22 \mathrm{E}+02$ & $1.25 \mathrm{E}+02$ & $1.33 \mathrm{E}+02$ & $1.36 \mathrm{E}+02$ \\
\hline
\end{tabular}


Table F.1-9

Thermoluminescent Dosimeter Results for CAU 367 (mrem)

(Page 4 of 4)

\begin{tabular}{|c|c|c|c|c|c|c|c|c|c|c|}
\hline \multirow{3}{*}{$\begin{array}{l}\text { Sample } \\
\text { Plot }\end{array}$} & \multirow{3}{*}{$\begin{array}{c}\text { TLD } \\
\text { Location }\end{array}$} & \multicolumn{3}{|c|}{ TLD 1} & \multicolumn{3}{|c|}{ TLD 2} & \multicolumn{3}{|c|}{ TLD 3} \\
\hline & & \multicolumn{3}{|c|}{ Element } & \multicolumn{3}{|c|}{ Element } & \multicolumn{3}{|c|}{ Element } \\
\hline & & 2 & 3 & 4 & 2 & 3 & 4 & 2 & 3 & 4 \\
\hline No plot & AT56 & $2.58 \mathrm{E}+01$ & $2.56 \mathrm{E}+01$ & $2.61 E+01$ & -- & -- & $\overline{--}$ & -- & $\overline{--}$ & - \\
\hline No plot & AT57 & $3.79 E+01$ & $3.70 E+01$ & $3.59 E+01$ & -- & -- & -- & -- & -- & - \\
\hline No plot & AT59 & $2.07 \mathrm{E}+01$ & $1.94 \mathrm{E}+01$ & $2.00 E+01$ & -- & -- & -- & -- & -- & - \\
\hline
\end{tabular}

-- = TLD was not installed 
Table F.1-10

Results for Background TLDs at CAU 367 (mrem)

\begin{tabular}{|c|c|c|c||}
\hline TLD Location & Element 2 & Element 3 & Element 4 \\
\hline \hline AT52 & $4.35 \mathrm{E}+01$ & $4.52 \mathrm{E}+01$ & $4.07 \mathrm{E}+01$ \\
\hline AT58 & $3.11 \mathrm{E}+01$ & $2.95 \mathrm{E}+01$ & $2.84 \mathrm{E}+01$ \\
\hline AT60 & $3.59 \mathrm{E}+01$ & $3.51 \mathrm{E}+01$ & $3.37 \mathrm{E}+01$ \\
\hline
\end{tabular}


Appendix G

\section{Sample Location Coordinates}




\section{G.1.0 Sample Location Coordinates}

One TLD was staged at the center of each of the CAU 367 sample plots. The GPS coordinates from this TLD location define the sample plot location. These coordinates and the GPS coordinates for TLDs staged at locations other than the sample plots are presented in Table G.1-1. The GPS coordinates for the background TLD locations are presented in Table G.1-2. The GPS coordinates for judgmental sample locations investigated as part of other releases at CAU 367 are listed in Table G.1-3.

Table G.1-1

Sample Plot and TLD Location Coordinates for the Primary Release at CAU 367

(Page 1 of 3)

\begin{tabular}{|c|c|c|c|}
\hline Sample Plot ${ }^{\mathrm{a}}$ & TLD Location & Easting & Northing \\
\hline \multicolumn{4}{|c|}{ Northeast Vector } \\
\hline$A$ & AT42 & 585,172 & $4,114,901$ \\
\hline$B$ & AT41 & 585,077 & $4,114,669$ \\
\hline $\mathrm{C}$ & AT44 & 585,316 & $4,115,229$ \\
\hline $\mathrm{D}$ & AT45 & 585,384 & $4,115,382$ \\
\hline \multicolumn{4}{|c|}{ East Vector } \\
\hline$E$ & AT33 & 585,109 & $4,114,475$ \\
\hline $\mathrm{F}$ & AT34 & 585,308 & $4,114,461$ \\
\hline $\mathrm{G}$ & AT36 & 585,775 & $4,114,442$ \\
\hline $\mathrm{H}$ & AT39 & 586,297 & $4,114,444$ \\
\hline \multicolumn{4}{|c|}{ South Vector } \\
\hline $\mathrm{J}$ & AT24 & 584,809 & $4,114,359$ \\
\hline $\mathrm{K}$ & AT55 & 584,987 & $4,113,859$ \\
\hline $\mathrm{L}$ & AT28 & 585,101 & $4,113,504$ \\
\hline$M$ & AT30 & 585,164 & $4,113,318$ \\
\hline \multicolumn{4}{|c|}{ Northwest Vector } \\
\hline $\mathrm{N}$ & AT01 & 584,443 & $4,114,641$ \\
\hline $\mathrm{P}$ & AT02 & 584,285 & $4,114,770$ \\
\hline $\mathrm{Q}$ & AT03 & 584,155 & $4,114,914$ \\
\hline $\mathrm{R}$ & AT05 & 583,892 & $4,115,162$ \\
\hline
\end{tabular}


Table G.1-1

\section{Sample Plot and TLD Location Coordinates for the Primary Release at CAU 367}

(Page 2 of 3 )

\begin{tabular}{|c|c|c|c|}
\hline Sample Plot ${ }^{\mathrm{a}}$ & TLD Location & Easting & Northing \\
\hline \multicolumn{4}{|c|}{ TLD Coordinates } \\
\hline No plot & AT04 & 583,993 & $4,115,036$ \\
\hline No plot & AT06 & 583,761 & $4,115,314$ \\
\hline No plot & AT07 & 583,621 & $4,115,449$ \\
\hline No plot & AT08 & 583,502 & $4,115,562$ \\
\hline No plot & AT09 & 584,522 & $4,114,793$ \\
\hline No plot & AT10 & 584,370 & $4,114,957$ \\
\hline No plot & AT11 & 584,095 & $4,115,231$ \\
\hline No plot & AT12 & 583,715 & $4,114,972$ \\
\hline No plot & AT13 & 583,577 & $4,115,026$ \\
\hline No plot & AT14 & 583,441 & $4,115,119$ \\
\hline No plot & AT15 & 583,696 & $4,114,372$ \\
\hline No plot & AT16 & 583,589 & $4,1144,43$ \\
\hline No plot & AT17 & 583,525 & $4,114,686$ \\
\hline No plot & AT18 & 583,435 & $4,114,741$ \\
\hline No plot & AT19 & 583,351 & $4,1148,06$ \\
\hline No plot & AT20 & 584,201 & $4,114,003$ \\
\hline No plot & AT21 & 584,116 & $4,113,931$ \\
\hline No plot & AT22 & 584,209 & $4,115,391$ \\
\hline No plot & AT23 & 584,331 & $4,115,455$ \\
\hline No plot & AT25 & 584,872 & $4,114,178$ \\
\hline No plot & AT26 & 584,943 & $4,113,964$ \\
\hline No plot & AT27 & 585,071 & $4,113,693$ \\
\hline No plot & AT29 & 585,021 & $4,113,842$ \\
\hline No plot & AT31 & 585,187 & $4,113,186$ \\
\hline No plot & AT32 & 585,227 & $4,112,975$ \\
\hline No plot & AT35 & 585,497 & $4,114,451$ \\
\hline No plot & AT37 & 585,939 & $4,114,443$ \\
\hline No plot & AT38 & 586,116 & $4,114,448$ \\
\hline No plot & AT40 & 586,507 & $4,114,431$ \\
\hline No plot & AT43 & 585,240 & $4,115,053$ \\
\hline No plot & AT46 & 585,457 & $4,115,589$ \\
\hline
\end{tabular}


Table G.1-1

\section{Sample Plot and TLD Location Coordinates for the Primary Release at CAU 367}

(Page 3 of 3)

\begin{tabular}{|c|c|c|c|}
\hline${\text { Sample } \text { Plot }^{\text {a }}}^{\text {Sam }}$ & TLD Location & Easting & Northing \\
\hline No plot & AT47 & 585,568 & $4,115,749$ \\
\hline No plot & AT48 & 585,636 & $4,115,946$ \\
\hline No plot & AT49 & 585,807 & $4,115,507$ \\
\hline No plot & AT50 & 585,993 & $4,115,389$ \\
\hline No plot & AT51 & 585,155 & $4,113,943$ \\
\hline No plot & AT53 & 585,892 & $4,111,953$ \\
\hline No plot & AT54 & 584,762 & $4,116,304$ \\
\hline No plot & AT56 & 584,962 & $4,120,167$ \\
\hline No plot & AT57 & 586,290 & $4,118,176$ \\
\hline No plot & AT59 & 587,452 & $4,109,908$ \\
\hline
\end{tabular}

${ }^{a}$ One TLD was staged in the center of each sample plot; the coordinates presented are from this TLD location.

Table G.1-2

Sample Location Coordinates for Background TLDs at CAU 367

\begin{tabular}{|c|c|c|}
\hline TLD Location & Easting & Northing \\
\hline \hline AT52 & 583,301 & $4,111,818$ \\
\hline AT58 & 588,757 & $4,114,979$ \\
\hline AT60 & 581,586 & $4,112,341$ \\
\hline
\end{tabular}

Nine aliquot sample locations were established at each plot for each composite sample. The VSP software (PNNL, 2007) was used to derive coordinates for a systematic triangular grid pattern based on a randomly generated origin or starting point. In some cases, aliquot locations were moved due to surface/subsurface obstructions or conditions (e.g., rocks, vegetation, and animal burrows). These offsets (distance and direction) of each aliquot location are recorded in the project files. It is important to note that if an offset was less than the nominal 4-in. width of core sampler, the original coordinate was not modified. 
Table G.1-3

\section{Sample Location Coordinates \\ for the Other Releases at CAU 367}

\begin{tabular}{||c|c|c|c||}
\hline Sample Location & Location Description & Easting & Northing \\
\hline \hline XB01 & Battery & 585,734 & $4,112,781$ \\
\hline XB02 & Battery & 585,488 & $4,113,083$ \\
\hline XB04 & Lead-Acid Battery & 586,186 & $4,113,731$ \\
\hline XB05 & Lead-Acid Battery Verification Sample & 586,186 & $4,113,731$ \\
\hline XB06 & Lead-Acid Battery Verification Sample & 586,186 & $4,113,731$ \\
\hline XH01 & Circle Road & 583,842 & $4,115,072$ \\
\hline XH02 & Circle Road & 583,713 & $4,114,918$ \\
\hline XM01 & Ess Mud Pit (CAS 10-09-03) & 584,898 & $4,113,781$ \\
\hline XP01 & Empty Paint Can & 585,400 & $4,113,588$ \\
\hline XS01 & Lead and Steel Shot & 584,189 & $4,114,915$ \\
\hline XT02 & Tar & 584,200 & $4,114,168$ \\
\hline XT03 & Tar & 585,893 & $4,112,975$ \\
\hline XT04 & Tar & 583,859 & $4,114,815$ \\
\hline
\end{tabular}




\section{G.2.0 References}

PNNL, see Pacific Northwest National Laboratory.

Pacific Northwest National Laboratory. 2007. Visual Sample Plan, Version 5.0 User's Guide, PNNL-16939. Richland, WA. 


\section{Appendix $\mathrm{H}$}

\section{Nevada Division of Environmental Protection Comments}

(1 Page) 


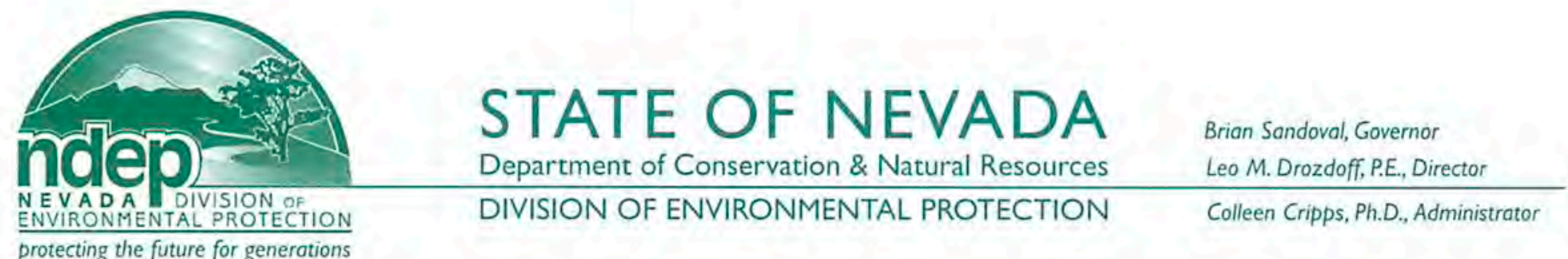

May 26, 2011

Robert F. Boehlecke

Federal Project Director

Environmental Restoration Project

National Nuclear Security Administration

Nevada Site Office

P. O. Box 98518

Las Vegas, NV 89193-8518

RE: Review of Draft Corrective Action Decision Document / Closure Report (CADD/CR) for Corrective Action Unit (CAU) 367: Area 10 Sedan, Ess and Uncle Unit Craters, Nevada Test Site, Nevada

Federal Facility Agreement and Consent Order

Dear Mr. Boehlecke,

The Nevada Division of Environmental Protection, Bureau of Federal Facilities (NDEP) staff has received and reviewed the draft CADD/CR for Corrective Action Unit (CAU) 367: Area 10 Sedan, Ess and Uncle Unit Craters, Nevada Test Site, Nevada. NDEP's review of this document did not indicate any deficiencies.

If you have any questions regarding this matter contact me at (702) 486-2850 ext. 233.

Sincerely,

\section{/s/ Jeff MacDougall}

Jeff MacDougall, Ph.D., CPM

Supervisor

Bureau of Federal Facilities

$\mathrm{JJM} / \mathrm{JW} / \mathrm{KC}: j j m$

cc: $\quad$ K. J. Cabble, ERP, NNSA/NSO, Las Vegas, NV

E. F. Di Sanza, WMP, NNSA/NSO, Las Vegas, NV

J. T. Fraher, DTRA/CXTS, Kirtland AFB, NM

A. L. Primrose NSTec, Las Vegas, NV

T. D. Taylor, N-I, Las Vegas, NV

P. K. Matthews, N-I, Las Vegas, NV

FFACO Group, PSG, NNSA/NSO, Las Vegas, NV 


\section{Library Distribution List}

\section{$\underline{\text { Copies }}$}

U.S. Department of Energy

National Nuclear Security Administration

Nevada Site Office

Technical Library

P.O. Box 98518, M/S 505

Las Vegas, NV 89193-8518

U.S. Department of Energy

Office of Scientific and Technical Information

P.O. Box 62

Oak Ridge, TN 37831-0062

Southern Nevada Public Reading Facility

c/o Nuclear Testing Archive

P.O. Box 98521, M/S 400

Las Vegas, NV 89193-8521

Manager, Northern Nevada FFACO

Public Reading Facility

c/o Nevada State Library \& Archives

100 N Stewart Street

Carson City, NV 89701-4285
1 (Uncontrolled, electronic copy)

1 (Uncontrolled, electronic copy)

2 (Uncontrolled, electronic copies)

1 (Uncontrolled, electronic copy) 